\title{
FURTHER STUDIES ON THE PLEISTOCENE GEOLOGY OF NORTHWESTERN IOWA
}

by

J. ERNEST CARMAN 


\section{TABLE OF CONTENTS}

INTRODUCTION _-.

Chapter I. Summary of Earlier Work-_-_-_-_-_- 24

Work preceding 1909-.... 24

Chamberlin in Geikie's Great Ice Age, 1894_................. 24

Preliminary work by Bain, 1896

Bain's work in Plymouth county, 1897_............ 25

Bain's work in Carroll county, 1898

Wilder's work in Lyon and Sioux counties, 1899_._._._._._._._. 27

Macbride's work in Osceola and Dickinson counties, 1899_._._._. 30

Macbride's work in Clay and O'Brien counties, 1900_........ 30

Macbride's work in Cherokee and Buena Vista counties, 1901_..... 31

Macbride's work in Sac and Ida counties_._._._.............. 32

Work of the writer from 1909 to 1916

Work published since 1916_- 36

Further studies in northwestern Iowa

Chapter II. The Iowan Drift Region

Correlation -

Topography -- 40

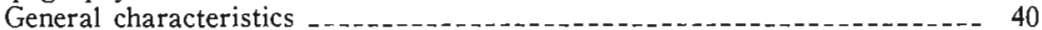

Description of the topography

Slightly rolling areas....... 42

Moderately rolling areas... 43

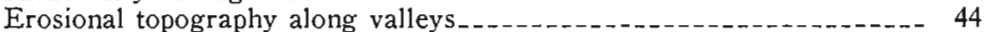

Aggraded areas_._. 46

Gravel hills

Gravel benches

Sand hills north of the Spencer flat... 47

The Iowan drift._. 48

General characteristics

Relation to the Loveland deposits

Some till exposures interpreted as Iowan. 52

Doupe farm

Pits of Cherokee Sand and Gravel Company

Other exposures _._.

The Iowan boundary

From the state line to Little Rock river................. 60

Along Little Rock river and Otter creek... 61

Alternative boundary in Lyon county

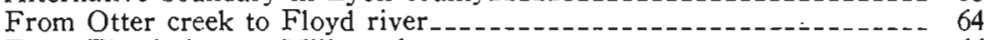

From Floyd river to Mill creek

Along Mill creek in southern O'Brien and northern Cherokee counties 68

From the mouth of Mill creek southeast to Maple river._._-_._._- 70

Alternative boundary just south of Cherokee._. 71

Along Maple river valley

From Maple river to Odebolt

From Odebolt to the south line of Sac county 81

The interbedded gravel and till

Distribution and description of exposures. 84

Origin - 89

The gravel hills

Nature of the gravel

Distribution and description of the gravel hills

Northeastern Lyon county..... 91 
Southwestern Nobles county, Minnesota_._._._._._._._._._. 92

Western Osceola county

Northern O'Brien county._._. 93

Along Willow creek in southern O'Brien county

Northern Cherokee county

Southeastern Cherokee county

Ida and Sac counties..._. 98

The origin of the gravel hills

Evidence of structure

Evidence of location

Evidence of material

Conclusions _...... 101

Chapter III. The Kansan Drift Region._._._._.

Topography --

General characteristics

Description of the topography-_-

The Kansan drift

General characteristics -

Source of material for the drift

History of the Kansan drift region

Gravel and sand masses included in the till

General characteristics._._._._.

Description of some typical exposures... 113

The origin of the sand and gravel boulders

Chapter IV. The Loess_._._._._._. 116

General characteristics and distribution

The region of thick loess

The northeast border of the thick loess

The region with loess of medium thickness..._.

The region of thin loess

Pebbles within and on the surface of the loess

Data concerning the nature and thickness of the loess

From Wall Lake west across southern Sac and Ida counties_.___._._- 124

From Early west across northern Sac and Ida counties...-...- 125

From Storm Lake across Buena Vista, Cherokee and Plymouth counties 126

O'Brien and Sioux counties._-_._. 130

Clay and Dickinson counties........ 131

Osceola and Lyon counties... 132

Southern Nobles county, Minnesota

Origin and age of the loess.

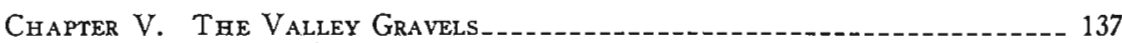

Nature of the gravels

Distribution and description of the valley gravels

The Big Sioux river drainage basin

The main valley

Rock river valley

Tributaries of Rock river-_.

Little Rock river and Otter creek...

Area east and southeast of Sibley. 142

Tom creek._.

Mud creek._-_-_-_- 144

Small tributaries of the Big Sioux..... 144

The Floyd river drainage basin

The main valley

Deep creek valley

The Little Sioux river drainage basin...... 149

The headwaters of the Little Sioux above Spencer_._._._._._._._. 149

Tributaries of the Little Sioux from the Wisconsin drift region....... 151 
PAGr.

Gravels of the Little Sioux valley from Spencer to its mouth._._._._. 152

Tributaries of the Little Sioux from the Iowan drift region.-.

Willow creek.

Waterman and Murry creeks.-155

Mill creek_.

Minor tributaries in Cherokee county

Tributaries of the Little Sioux in the Kansan drift region...- 161

The Maple river drainage basin.

The Boyer river drainage basin... 163

Fossils from the valley gravels

Origin and age of the valley gravels.

Chapter VI. Analyses of Perbles.

Tables of analyses of pebbles

Table I. Pebbles from till or gravel within the Wisconsin region.-.- 172

Table II. Pebbles from valley gravels of the Wisconsin region

Table III. Pebbles from valley gravels of probable Wisconsin outwash in valleys just beyond the boundary -

Table IV. Pebbles from the gravel hills of the Iowan region.-..-- 175

Table V. Pebbles from valley gravels of the Iowan region

Table VI. Pebbles from valley gravels in Iowan drainage lines of the Kansan region.-...- 178

Table VII. Pebbles from valley gravels of the Kansan region in draiñage lines not reached by Iowan or Wisconsin drainage 180

Table VIII. Pebbles from gravel masses enclosed in or associated with till that is apparently Kansan... 181

Table IX. Summary of averages of analyses of pebbles from the several types of gravels._. 182

Chapter VII. Geologic History and Conclusions

Pleistocene Geology

Nebraskan age

Kansan age... 183

Iowan age....

Wisconsin age

Summary of conclusions.

Iowan region

Kansan region.-. 186

The loess.

Interbedded gravel and till

The gravel hills___. 187

The valley gravels. 187 


\section{LIST OF ILLUSTRATIONS}

FIGURE PAGE

1. Outline map of Yowa showing counties and principal towns_-_-_-_-_- 22

2. Pleistocene map of the Mississippi valley showing lowan drift regions_-_-_- 23

3. Map of northwestern Iowa made by compiling Pleistocene maps in county reports _.

4. View across level area of Iowan plain in O'Brien county... 42

5. View across sharply dissected Iowan drift region in Buena Vista county _..- 44

6. Cross profile of tributary valley of Little Sioux

7. Contour map of northwest quarter, section 13, Cherokee township, Cherokee county _............. 53

8. Columnar sections of exposures on Doupe farm

9. Contour map showing gravel pits on Turner farm

10. Sketch of exposure showing lowan till on gravel, OSBrien county

11. Exposure in Cherokee county showing Kansan till and gravel mass_-_-_- 75

12. Columnar sections of exposures in Mill creek, Cherokee county

13. Sketches showing cross-bedding and basin structure of sand, O'Brien county 93

14. Cross section of pit in gravel hill, O'Brien county

15. View of gravel hill in Iowan region, O'Brien county

16. Loess-covered region north of Turin, Monona county

17. Sketch of exposure in Plymouth county, showing loess over old soil and leached clay ..... 123

18. Exposure in trench in Sibley

19. Profiles along Little Sioux river valley...

20. Sketch showing altitude of benches along Little Sioux valley

21. Profiles along Waterman creek valley

22. Profiles along Murry creek valley _.

23. Profiles along Mill creek valley

24. Map of part of Cherokee county showing flat of Mill creek.

PLATE

PAGE

I. Map of the Pleistocene deposits of Northwestern Iowa. Pocket

II. Map of the drift sheets of Iowa, to face 


\section{FURTHER STUDIES ON THE PLEISTOCENE GEOLOGY OF NORTHWESTERN IOWA}

\section{INTRODUCTION}

The Iowa Geological Survey published in 1917 a report by the writer entitled The Pleistocene Geology of Northwestern Iowa. ${ }^{1}$ This report of 1917 deals with an area of about 9,000 square miles comprising twelve entire counties and halves of four other counties; four rows from north to south, and three and one-half rows from west to east. 'The names and relative locations of these counties are given in figure 1.

In the report of 1917 Chapter I gives a summary of the earlier work on the Pleistocene of northwestern Iowa; Chapter II treats the Wisconsin drift region; Chapter IJI deals with the Kansan drift region, including all of northwestern Iowa west of the Wisconsin boundary; Chapter IV treats the gravels associated with the Kansan drift; Chapter $\mathrm{V}$ treats the gravels found in valleys of the Kansan region; Chapter VI discusses the Nebraskan drift; Chapter VII traces the geologic history of northwestern Iowa.

Later work in northwestern Iowa has shown that those parts of the report of 1917 having to do with the Kansan drift region, as there interpreted, should be revised in order to recognize an Iowan drift region in the eastern part of the area there called Kansan. The present report is, therefore, to replace Chapters III, IV and V of the report of 1917. The recognition of the Iowan drift region requires so many changes that it has been deemed advisable to present again, in rearranged form, most of the data included in these chapters III, IV and V. Small parts of Chapter VII, Geologic History, having to do with the Kansan (pages 438 to 440 ), and of Chapter VIII, Summary and Conclusions, having to do with the Kansan (page 443) and the associated gravels (pages 444 to 445 ), should also be revised to accord with the new interpretation. The chapters on the Wisconsin and the Nebraskan in the report of 1917 need no revision. The relation of this Iowan drift region of northwestern Iowa to the other drift regions

1 Carman, J. Ernest, The Pleistocene Geology of Northwestern Iowa: Iowa Geol. Survey, Vol. XXVI, pp. 233-445, 1917. 


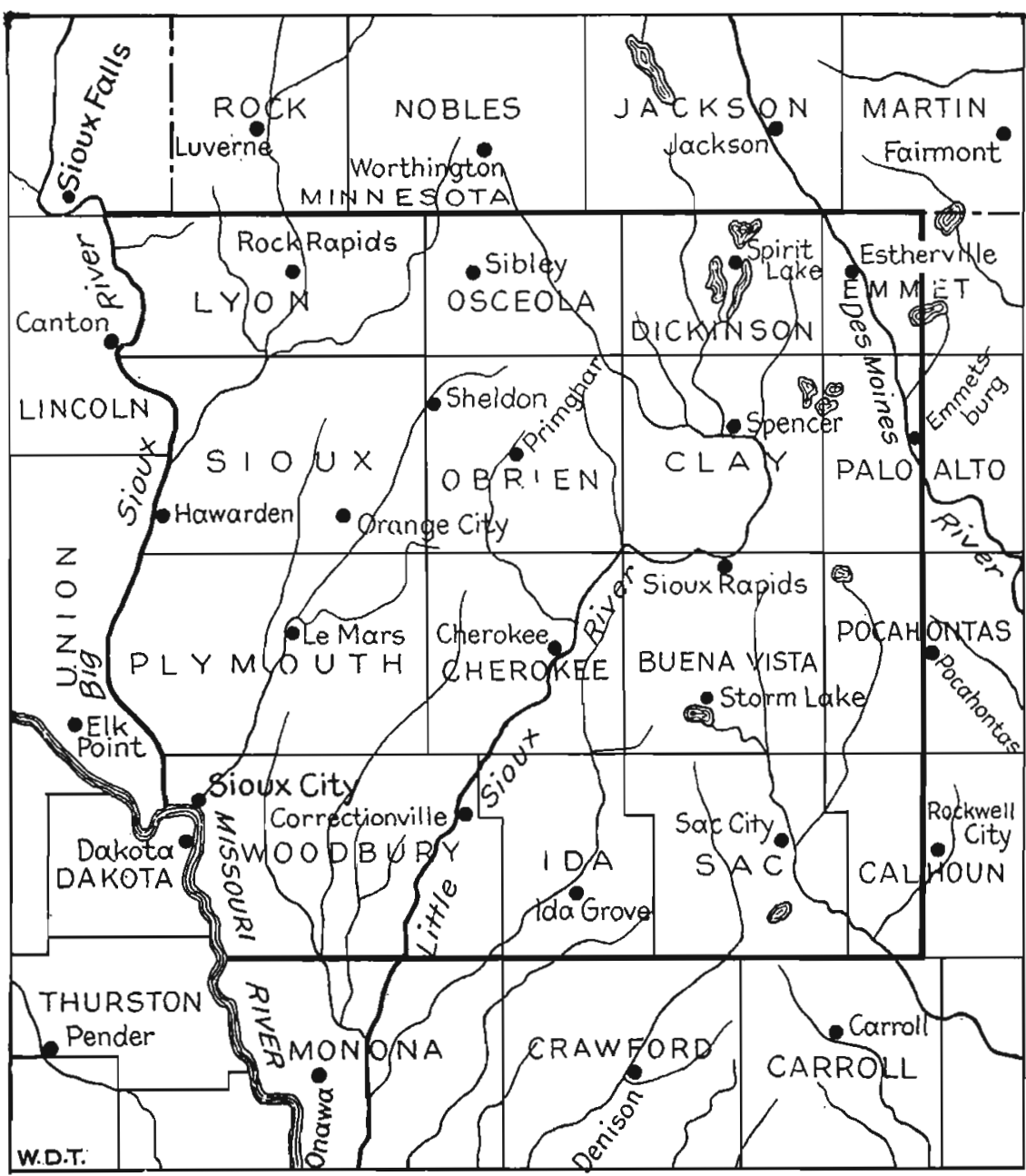

FrG. 1.-Outline map of northwestern Iowa showing counties and principal towns. The area treated in this report is enclosed within the heavy lines.

of the Mississippi valley is shown in figure 2, which has been published by Kay.

In the present report Chapter I summarizes that part of the earlier work in northwestern Iowa which bears directly on the area here called Iowan. Chapter II treats the Iowan drift region including certain associated gravels. Chapter III treats the Kansan drift region. Chapter IV deals with the loess and Chapter $V$ with the gravels in the valleys chiefly of the Iowan drift region. The report closes with a 
summary of the conclusions reached concerning the various subjects treated in the report.

In the discussion of several subjects the material of a more detailed character is placed in smaller type and may be omitted by the general reader without losing the continuity of the discussion.
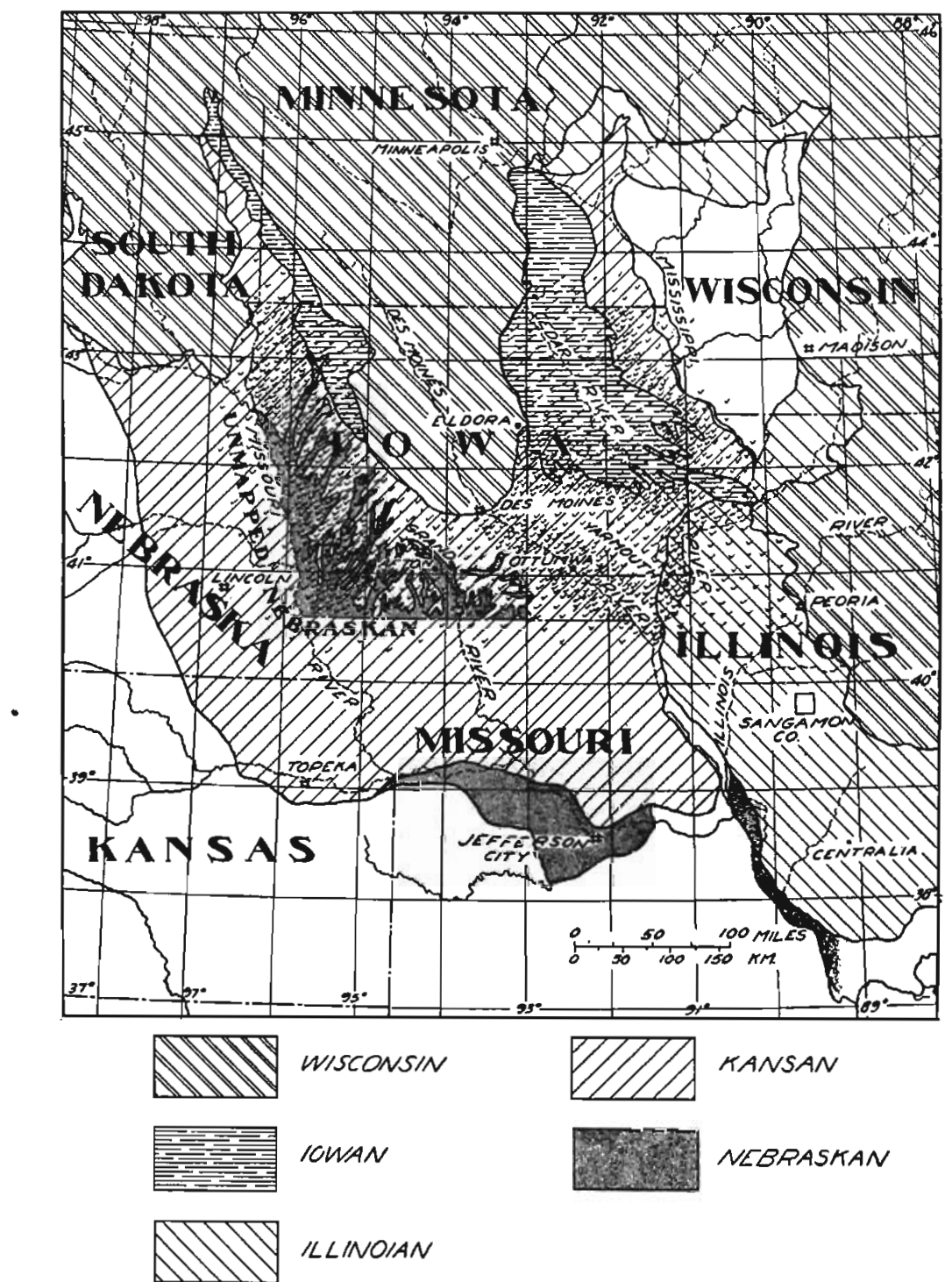

IOWAN

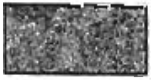

NEBPASKAN

\section{$I L L I N O / A N$}

Fig. 2--Pleistocene map of the Mississippi valley showing the relation of the Iowan drift region of northwestern Yowa (horizontal broken lines) to the other drift regions. (Kay Am. Jour. Sci., vol. XXI, p. 159, fig. 1.) 


\section{CHAPTER I}

\section{SUMMARY OF EARLIER WORK \\ Work Preceding 1909}

The summary which follows does not attempt to review all the geologic work in northwestern Iowa or even all the work on the Pleistocene but emphasizes particularly those writings which bear in some way on the question of the age of the drift of that part of northwestern Iowa west of the Wisconsin boundary. These writings were briefly noted as a part of Chapter I of the 1917 report but because of their bearing on the primary problem of the present report they are here discussed much more fully.

Chamberlin in Geikie's Great Ice Age.-The first assignment of some part of northwestern Iowa to a drift sheet younger than the Kansan and older than the Wisconsin was made by Dr. T. C. Chamberlin in his chapter on North America in". James Geikie's "The Great Ice Age" (1894). Plate XV of that work shows an area of Iowan drift 25 to 30 miles wide west of the Des Moines lobe in northwestern Iowa, including most of the second tier of counties east of Big Sioux and Missouri rivers. To the west of this belt he mapped Kansan drif.t.

Preliminary Work by Bain, 1896.-The first suggested assignment of this character in the reports of the Iowa Geological Survey is in Volume VII (1897), in the administrative report of Doctor Calvin for 1896. On page 18, in narrating the glacial stages affecting Iowa, he wrote: "Fourth Glacial Stage, Iowan. During this stage the northern half of Iowa was overrun by glaciers. The southern limit of this incursion may be traced a few miles north of a line drawn from Iowa City to Des Moines, and then deflected northwestwardly to Plymouth county." On page 20, he wrote: "Prof. R. D. Salisbury, . . . . accompanied Mr. Bain upon a short trip across the northern portion of the state, going as far west as Sioux City and Rock Rapids. The topographic characteristics of the Wisconsin and Iowan were studied and the probable equivalence of the drift sheets east and west of the Des Moines lobe was tentatively decided upon. The correlation forms a good basis for next season's work,". 
Volume VI of the Iowa Geological Survey bears the publication date of 1897, as does Volume VII, but the date of the letter of transmittal is December 31, 1897, one year later than that of Volume VII. Volume VI apparently came out later for it contains footnote references to Volume VII. In this Volume VI is a paper by H. F. Bain entitled "Relations of the Wisconsin and Kansan Drift Sheets in Central Iowa". On page 462 he wrote: "There is in the northwestern portion of the state a drift which in physical constitution and topographic development resembles the Iowan of eastern Iowa, and it has been provisionally correlated with that formation." For this provisional correlation he refers to Plate XV of Geikie's Great Ice Age and the statement of Calvin on page 20 of Volume VII of the Iowa Geological Survey as quoted in the preceding paragraph.

On a "Preliminary Outline Map of the Drift Sheets of Iowa" forming Plate XXVIII, opposite page 467 of this report by Bain, northwestern Iowa west of the Wisconsin boundary is set off on the south by a line labeled "Probable Limit of Iowan Drift". This line leaves Big Sioux river in southwestern Plymouth county and runs eastward across the south part of this county, the southwest corner of Cherokee county, the northeast corner of Ida county, and the northwest corner of Sac county, to the Wisconsin boundary in northern Sac county. This probable Iowan area of northwestern Iowa included all of Lyon, Osceola, Sioux and O'Brien counties, the northern four-fifths of Plymouth county, practically all of Cherokee county, the western parts of Dickinson, Clay and Buena Vista counties, and small areas in northeastern Ida and northwestern Sac counties.

Bain's Work in Plymouth County, 1897.-Volume VIII (1898) of the Iowa Geological Survey contains a report on the geology of Plymouth county by H. F. Bain. He spoke of this as "a report on the first area studied by the Survey with especial reference to the drift problems of northwestern Iowa" (page 319). He emphasized the freshness of the till below the loess, saying that it showed little sign of leaching or oxidation and had no ferretto zone. The age of the till was discussed rather fully (pages 341 to 351 ), the following four possibilities being considered: (1) Kansan, (2) Illinoian, (3) Iowan, (4) Extra-morainic Wisconsin. These possibilities were presented from the viewpoints of topographic development, physical character, alteration, and stratigraphic relationship, and it was found that some viewpoints favored one interpretation, some another. In conclusion 
he wrote (page 350): "The balance of evidence would seem to indicate that the drift is either Illinoian or Iowan, and since it has already been provisionally referred to the latter it may for the present rest in that category. Clearly it is not Kansan, and while certain elusive evidence not yet well enough in hand to discuss, seems at times to link it with the Wisconsin, the bulk of the phenomena seems to indicate an earlier age."

In the Administrative Report of the Assistant State Geologist in this same Volume VIII Bain listed as one of the results of his work in northwestern lowa "the approximate determination of the southern limits of the Iowan (?) drift sheet in the region" (page 27) and noted the presence of Iowan (1) at several places near Rock Rapids in Lyon county, (2) in eastern Sioux county, (3) in Cherokee county, (4). near Storm Lake in Buena Vista county just outside the Wisconsin moraine, (5) near Correctionville and at Sioux City in Woodbury. county, (6) at Ida Grove and for some considerable distance south in Ida county, and (7) at Carnarvon in southeastern Sac county. On page 351 in the Plymouth county report he indicated that the boundary between this Iowan (?) of northwestern Iowa and the Kansan farther south was difficult to determine because of the thickness of the loess and the scarcity of exposures, and it could "only be outlined as running from Carroll northwest through the northern tier of townships in Craw ford county". This indicated boundary is 20 to 25 miles south of that drawn by Bain a year earlier as shown on Plate XXVIII of Volume VI, and it placed in the Iowan at least the northern part of Woodbury county, which he in his earlier report on this. county ${ }^{2}$ had called Kansan drift. Bain apparently at this time placed in the Iowan(?) all of northwestern lowa outside the Wisconsin moraine which had a relatively fresh drift to the surface.

Bain's Work in Carroll County, 1898.-This interpretation, which placed all the fresh drift of northwestern Iowa as far south as central Carroll county in the Iowan, was not borne out by the next season's work, for in the Administrative Report of the Assistant State Geologist in Volume IX, Mr. Bain wrote (page 26): "In Carroll county one of the interesting results of the season's work has been the demonstration that much of the extra-morainic drift, heretofore believed to be young and provisionally correlated with the Iowan, belongs to an anomalous phase of the Kansan. What may be the correct age of.

2 Iowa Geol. Survey, Vol. V, p. 279. 1896. 
the extra-morainic drift north and west of Carroll county can not yet be stated."

In this same volume is Bain's report on the Geology of Carroll County $^{3}$. He interpreted all the county outside the Wisconsin as Kansan, recognizing two types of Kansan outcrops. The first is that, typical for the Kansan farther south, which shows ferretto, leaching, rotted bowlders, etc., at the top of the drift. The second is an abnormal type in which these phenomena are lacking and fresh till continues to the top. He found both types in the same region but in general found an increase of the unleached type to the west and the north in the county. Both types were overlain by the loess which was deposited after the erosion of the Kansan region and it was evident that they were but different phases of the same drift. He recognized the fact that the unleached type resembled closely the Kansan drift commonly 5 to 10 feet below the ferretto and interpreted these abnormal exposures as being due to erosion, which had removed the ferretto and leached zone before the loess was deposited. On page 88 he wrote: "No attempt can be made here to fix the age of the extra-morainic and fresh looking drift in the counties to the north. The work of the present field season has shown that the reference of this drift to the Iowan is probably wrong."

Wilder's Work in Lyon and Sioux Counties, 1899.-In Volume X appeared a report by Frank $A$. Wilder on the geology of Lyon and Sioux counties ${ }^{4}$ in the northwest corner of the state next north of Plymouth county, which Bain had tentatively interpreted as Iowan. Wilder noted (page 125) that the drift of northwestern Iowa had never been positively identified with any of the established drift sheets of other parts of the state and that one of the reasons for undertaking at that time the geological study of Lyon and Sioux counties was to obtain, if possible, information that would make such correlation possible. He stated that the drift of these counties was the same as that in Plymouth and Woodbury to the south and that no line of separation had been found between this unleached drift of northwestern Iowa and the typical Kansan of southern Iowa, which continued north to Carroll county, where exposures of the typical southern Iowa Kansan, with ferretto, and of the unleached northwest Iowa till both ex-

\footnotetext{
3 Bain, H. F., Geology of Carroll County: Iowa Geol. Survey, Vol. IX, pp. 49-107, 1899.

4 Wilder, Frank A., Geology of Lyon and Sioux Counties: Iowa Geol. Survey, Vol. X, pp. $81-184,1900$.
} 
isted in the same region." He thought that this lack of alteration and leaching of the northwest Iowa drift might be accounted for by the smaller rainfall of northwestern Iowa as compared with that of southern Iowa and by the nature of the topography.

Wilder noted (page 132) that: "Topographically the drift is, perhaps, more closely related to the Iowan" but if, as commonly held, the loess was related to the Iowan the underlying drift could not be Iowan, since evidently a considerable interval elapsed between the deposition of the drift and the overlying loess. In conclusion he wrote: "Considering everything, it seems safer to consider the loess-covered drift of Lyon and Sioux counties as Kansan until something is found in the way of a southern boundary to distinguish it from the recognized Kansan farther south." (Figure 3.)

Wilder mapped the extreme northeast corner of Lyon county, approximately the northeast half of Elgin township, as "Wisconsin Drift" with patches of "Altamont Moraine" (page 118) and in the text (pages 132 to 138) treated it all under the heading "The Altamont Moraine" stating that all of this area in Lyon county was morainic. $\mathrm{He}$ described this region in a very positive way as without a loess covering, and with a fresh drift, yellow in color, only slightly oxidized, invariably unleached. Southwest of the Altamont moraine he mapped (page 118) a belt with an average width of about four miles as "Wisconsin Partially Stratified"' and interpreted it as outwash from the Wisconsin.

The first interpretation of northeastern Lyon county as Wisconsin was recorded by Bain in Volume IX published one year earlier than the report by $W$ ilder. In his Administrative Report in this volume Bain commented on a trip through northwestern Iowa and adjacent portions of Minnesota and South Dakota, in company with J. E. Todd and Frank Leverett, and wrote (page 26): "Mr. Leverett traced the morainic hills of the Wisconsin drift into the northeast corner of Lyon county, and it seems probable that other changes in the mapping of the drift sheets of that region will be necessary." Wilder made no reference to this work of Mr. Leverett, but he must have known of it because of the close association of Bain with the work of Wilder in Lyon county.

These interpretations by Wilder were apparently concurred in by Bain, who had previously interpreted differently the drift of Plymouth

5 Iowa Geol. Survey, Vol. IX, pp. 82-85 and map, p. 106, 1899. 
county to the south. In the Administrative Report of the Assistant State Geologist in Volume X, Bain wrote (page 30): "In company

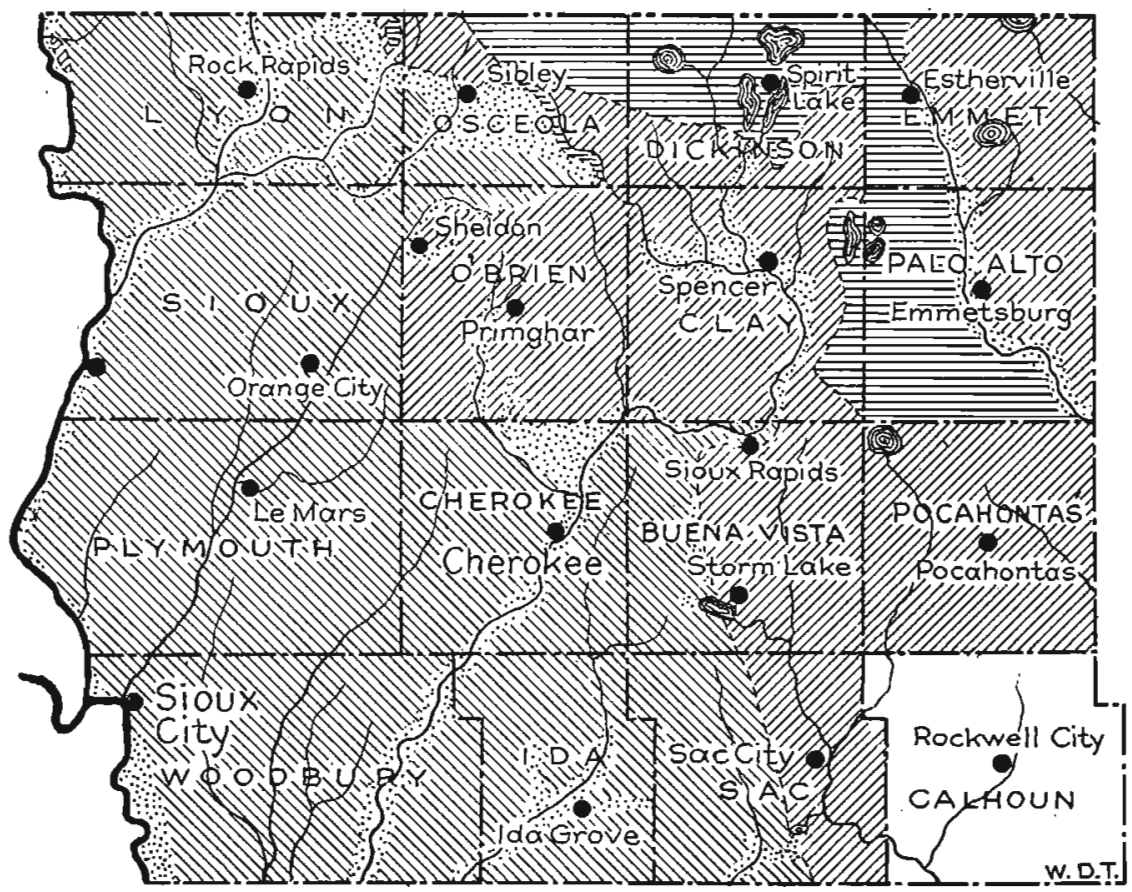

Frc. 3. A map of northwestern Iowa made by compiling the Pleistocene maps in the county reports. 17 "Kansan drift" of Woodbury, Ida and Sac counties; "Loess overlying older drift ties; "Provisionally Iowan" of Plymouth county. "Wisconsin Drift" of Lyon, Osceola, Dickinson, O'Brien, Palo Alto, Buena Vista,
Pocahontas and Sac counties; "Wisconsin Drift Plain" of Clay county; "Wisconsin Plain" of Emmet county.

"Altamont Moraine" of Lyon county; "Wisconsin Moraine" of Osceola county; "Knobby Drift, Morainic" of Dickinson county; "Knobby Drift" of Clay county "Wisconsin Drift. affected by Morainic Knobs" of Emmet county; "Morainic Deposits" of Palo Alto county.

P.:- "Wisconsin Partially Stratifed" of Lyon, Sioux, Osceola, Dickinson and Clay Gravels" of Cherokee county; "Alluvial Deposits" of Emmet, Palo Alto, Cherokee, Buena Vista and Sac counties; "Alluvium" of Ida county.

with Mr. Wilder I made a bicycle journey from Carroll county northwest as far as Sioux Falls, studying the drift of the intervening region. Mr. Wilder then took up the problem and his report, appearing in this volume, shows how successfully he has attacked it. I have been over most of the region in his company or alone, and would wish heartily to concur in his findings." In the Administrative Report of 
the State Geologist, Doctor Calvin wrote (page 15): "Mr. Wilder has also shed much light upon the vexed question of the age of the drift of the northwestern part of the state. His conclusions, while differing somewhat from those previously held by the Survey, are founded on careful study and seem worthy of every confidence. Probably a final opinion on the subject can not be rendered until more of the region sliall have been investigated."

Macbride's Work in Osceola and Dickinson Counties, 1899.-. Tn the same volume with Wilder's report on Lyon and Sioux counties is a report by Professor Macbride on the Geology of Osceola and Dickinson Counties ${ }^{6}$, which lie next east of Lyon county along the state line. Macbride continued the mapping units used by Wilder in Lyon county eastward into Osceola county (figure 3). The northwest part of Osceola county adjoining Wilder's "Wisconsin Drift" of northeastern Lyon county, the southeast part of Osceola county, and the southern third of Dickinson county were mapped as "Wisconsin Drift" outside the distinctly knobby area to the north which was mapped as "Wisconsin Moraine". The area of "Wisconsin Partially Stratified" which was continued from Lyon county with a width of two miles on the county line was mapped as broadening out in the central part of Osceola county to an area six to eight miles across and thence narrowing again to two to three miles where it strikes the south boundary of the county west of Ocheyedan river. The southwest corner of Osceola county was mapped as "Loess, overlying older drift" and provisionally referred to the Kansan (page 218).

Macbride's Work in Clay and O'Brien Counties, 1900.-In Volume $\mathrm{XI}$, one year later, Professor Macbride reported on Clay and O'Brien counties. ${ }^{7}$ The eastern edge of Clay county was mapped as "Knobby Drift", terminal moraine of Wisconsin age (figure 3). All the rest of Clay county and all of O'Brien county except the northwest corner, were mapped as "Wisconsin Drift". A narrow wedge-shaped area in the northwest corner of O'Brien county, 18 miles long from east to west and only $51 / 2$ miles wide at the west line, was mapped as "Loess, overlying older drift (Kansan)", apparently to match up with the similar area of southwestern Osceola county as mapped the previous year. The unit of "Wisconsin Partially Stratified" used by

6 Mazbride, T. H., Geology of Osceola and Dickinson Counties: Iowa Geol. Survey, Vol. X, pp. $185-239$, 1900 .

pp. $185-239,1900$. pp. 461-508, 1901. 
Wilder in Lyon county and continued by Macbride across Osceola county to the O'Brien county line was not used in the mapping of O'Brien county. The "Wisconsin Drift" of the O'Brien county map joins along the west line of the county with the "Kansan Drift" of the earlier Sioux county map of Wilder (figure 3), but no discussion of the lack of agreement or what caused the change of opinion concerning this region was given.

This mapping of Macbride in Clay and O'Brien counties created a large area of "Wisconsin Drift" in northwestern Iowa lying outside the Wisconsin moraine, an extra-morainic Wisconsin drift. In Volume XI there was published as Plate II a "Preliminary Outline Map of the Drift Sheets of Jowa," and, in accord with this work of Macbride, a considerable area in northwestern Iowa, including most of O'Brien and Clay counties and parts of Osceola, Dickinson, Cherokee and Buena Vista counties, was shown as "Wisconsin" but lying outside of the "Wisconsin Moraine."

Macbride's Work in Cherokee and Buena Vista Counties, 1901.Subsequent work to the south evidently did not bear out this conclusion concerning the extra-morainic Wisconsin area, for in his report on Cherokee and Buena Vista counties, ${ }^{8}$ which appeared one year later in Volume XII, Professor Macbride mapped Cherokee county, which - lies south of O'Brien, and the west half of Buena Vista county, next south of Clay county, as "Loess, overlying older drift (Kansan)". This abuts on the north at the county lines against the extra-morainic "Wisconsin Drift" area of O'Brien and Clay counties, as is shown in figure 3. The central and east parts of Buena Vista county were mapped as "Wisconsin Drift" but without a morainic belt along the boundary.

The previous assignment of the drift of O'Brien and Clay counties to the Wisconsin was questioned (page 319 ), with the suggestion that it might prove to be Early Wisconsin or even older. The problem was evidently considered the same as that in Plymouth county, to which report the reader was referred for a fuller presentation of the problem. In the Plymouth county report the drift had been provisionally referred to the Iowan. ${ }^{\circ}$

A second "Preliminary Outline Map of the Drift Sheets of Iowa"

8 Macbride, T. H., Geology of Cherokee and Buena Vista Counties: Iowa Geol. Survey, Vol.

9 Iowa Geol. Survey, Vol. VIII, pp. 341-351, 1898. 
appeared in 1904 in Volume XIV.10 Like the earlier map ${ }^{11}$ it shows an area of "Wisconsin" west of the "Wisconsin Moraine," but the west boundary of this area is five to ten miles farther east in.O'Brien, Cherokee and Buena Vista counties. The area includes most of Clay, Osceola and O'Brien counties and smaller parts of Dickinson, Buena Vista, Cherokee and Lyon counties. A very similar map was published in 1905 in Bulletin 2 of the Iowa Geological Survey, but on this map the Wisconsin Moraine was not shown and the "Wisconsin Drift" area continued unbroken westward to the west boundary of the extra-morainic Wisconsin of the other map.

Macbride's Work in Sac and Ida Counties. - In Volume XVI Professor Macbride reported on Ida and Sac counties, ${ }^{12}$ which lie to the south of Cherokee and Buena Vista counties. He showed the Wisconsin boundary extending north-south across Sac county and connecting up with the earlier tracing in Buena Vista county to the north and Carroll county to the south. The west half of Sac county and all of Ida county were mapped as Kansan drift (figure 3 ).

The work in Sac and Ida counties completed the county report work on that part of northwestern Iowa with which we are concerned. There is considerable lack of agreement between certain of the county maps and some contradictions in the texts. This lack of agreement is shown on figure 3 , which was made by compiling the Pleistocene maps of the county reports. New interpretations were adopted in some cases without showing that the earlier ones were no longer tenable. In some cases divisions were placed upon maps without discussion, and boundaries were mapped without being traced in the text and without discussion of the characters upon which the boundaries were based. This makes it difficult to determine just what the final opinion was on certain points. Thus the matter stood when the writer began his studies in northwestern Iowa in 1909.

\section{Work of the Writer from 1909 to 1916}

The work of the writer in northwestern Iowa began in 1909 with the problem of retracing the Wisconsin drift boundary on the west side of the Des Moines lobe north of Carroll county. ${ }^{13}$ This retracing left

\footnotetext{
10 Iowa Geol. Survey, Vol. XIV, P1. III, 1904.

11 Iowa Geol. Survey, Vol. XI, P1. II, 1901.

12 Macbride, T. H., Geology of Sac and Ida Counties: Iowa Geol. Survey, Vol. XVI, pp. 509. $562,1906$.

13 Iowa Geol. Survey, Vol. XXVI, pp. 251-320, 1917.
} 
outside the Wisconsin boundary that questionable area which had been variously interpreted by earlier-writers as Wisconsin, extra-morainic Wisconsin, Early Wisconsin, Iowan, or Kansan. This questionable area was studied during parts of the field seasons of 1910 and 1911. Various lines of evidence, chiefly topographic, suggested that the eastern part of this area should be assigned to a separate drift region intermediate between the Kansan on the west and the Wisconsin on the east. However, a super-Kansan drift sheet could not be generally separated and the topography did not seem to afford a consistent boundary line. Further, it was recognized that this questionable area corresponded most nearly to the Iowan of northeastern Iowa, and the identity of the Iowan was at that time very strongly questioned by most geologists outside of Iowa and probably by some within the state. It appeared, therefore, that to attempt to establish a post-Kansan pre-Wisconsin drift region in northwestern Iowa would be to create another Iowan problem. The conclusion was reached that all of northwestern Iowa west of the Wisconsin boundary was of Kansan age and a report was prepared by the writer with this interpretation.

It was on the basis of this conclusion that the "Map of Iowa Showing Drift Sheets," published as Plate LXV of Volume XXIV (1913) of the Iowa Geological Survey, was prepared. This map shows the Kansan drift over all of northwestern Iowa west of the Wisconsin boundary, as traced in the work of 1909. This map was reproduced as Plate XIV of Volume XXVI. (1917).

During the summer of $1912 \mathrm{Mr}$. Frank Leverett of the United States Geological Survey, working in southwestern Minnesota, recognized a drift region between the Wisconsin and Kansan and traced it southward to the Minnesota-Iowa line. This corresponded to the division south of the state line which had been tentatively considered by the writer in 1910 and 1911 as intermediate in age between the Wisconsin and Kansan. Mr. Leverett found this division very distinct in Minnesota and bordered by a moraine which he traced from Watertown, South Dakota, through southwestern Minnesota to the Iowa line. ${ }^{14}$

In 1913 the writer re-examined this intermediate area in northwestern Iowa and compared it with Leverett's area in southern Nobles county north of the state line. It was found that the characters of Leverett's area continued into Iowa with decreased distinctness and that a

14 Letter from Mr. Leverett to the writer in December, 1912. 
very indefinite boundary could be traced southward across eastern Lyon, northeastern Sioux, southwestern O'Brien, eastern Cherokee, northeastern Ida and southwestern Sac counties to the point where it passed beneath the Wisconsin boundary. It was then decided to make this the continuation in Iowa of Leverett's area. In Iowa the recognition of this intermediate area rested almost entirely on topography.

The writer then revised his report on northwestern Iowa on the basis of the existence of a drift sheet intermediate in age between the Kansan and the $W$ isconsin. In the manuscript this region was called Iowan with a chapter entitled "The Iowan Drift Region." The reasons for using the term Iowan were given but with the qualifying statement "a positive correlation has not as yet been made with the Iowan drift region of eastern Iowa."

Although the writer then agreed with Mr. Leverett in the recognition of this intermediate drift region, they did not agree as to its age. The writer believed that a loesslike clay which exists over the intermediate drift region was the equivalent of and the continuation of the Missouri river loess, which it was generally agreed was the equivalent of the Peorian loess of eastern Iowa and, therefore, that the intermediate drift region must be Iowan or older. Mr. Leverett, on the other hand, believed, in 1913, that this intermediate region was Wisconsin and so published concerning it in 1919. ${ }^{15}$

The manuscript on northwestern Iowa recognizing the Iowan drift region was submitted to the Director of the Iowa Geological Survey in May, 1915, but because of the lack of agreement noted above as to the correlation of the intermediate drift region the publication of the report was deferred from time to time.

In 1916, the writer, in company with the Director of the Iowa Survey, Doctor Kay, returned to northwestern Iowa to attempt to solve the question of the age of the intermediate drift area. A more detailed study of the loesslike clay that overlies the intermediate drift area confirmed the earlier opinion of the writer and convinced Doctor Kay that this loesslike clay is the continuation of, and the equivalent of, the loess of the Kansan region, which was generally considered to be Peorian. It was, therefore, impossible to agree with Mr. Leverett that this intermediate drift region was Early Wisconsin in age.

The writer had always questioned somewhat the identity of the intermediate area as a distinct drift region, and after showing in 1916

15 Minnesota Geol. Survey, Bull. 14, pp. 51-52, and map in pocket, 1919. 


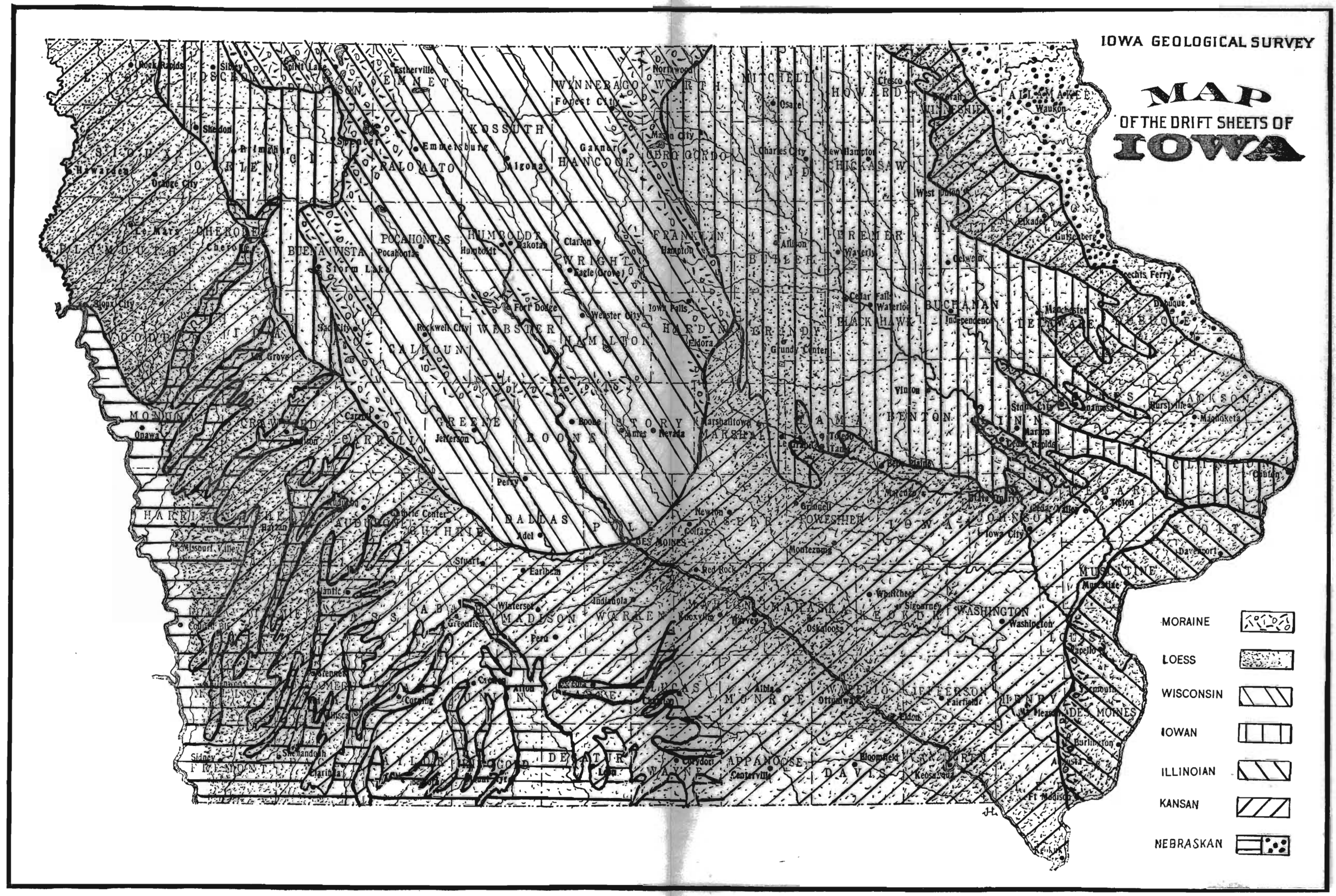


that it must be preloess in age he again reviewed the bases for its recognition. In view of the fact that there was no generally recognizable super-Kansan drift sheet, and that the boundary between the Kansan and the supposed intermediate area was in general indefinite. and questionable, the writer returned, at the end of the field season of 1916 , to the conclusion which he held in 1911, that all of northwestern Iowa west of the Wisconsin boundary belonged to the Kansan drift region.

On the basis of this interpretation the manuscript was again revised and this time published as "The Pleistocene Geology of Northwestern Iowa." ${ }^{\prime \prime}$ There are many parts of this report of 1917 that might be reviewed here, but the more important conclusions bearing on the subjects with which we are concerned in the present report may be shown by a few quotations from the section entitled "Summary and Conclusions" (pages 442-445).

"Kansan Drift.-All of northwestern Iowa west of the Wisconsin drift boundary is assigned to the Kansan drift region on the basis of the identity of the till and the presence of a mantle of loess over the entire region. The absence of leached Kansan till in northwestern Iowa is explained by the removal of this leached zone by erosion of the entire region below the original level at which leached till may have formed.

"Gravel Bowlders and Gravel Hills.-The gravel and sand masses included in the till are parts of frozen gravel deposits which were plowed up by the advancing ice sheet. As is shown by the composition of the gravel, by the freshness of the material and by the clay-balls, most of these masses are of the same age as the inclosing till. They represent deposits made in front of the advancing ice sheet, which a little later plowed them up.

"The gravel hills of the Kansan drift region are included gravel bowlders which have been exposed at the surface by the removal of the inclosing till. They come to stand above the surface of the till by the relatively greater resistance to erosion of the porous gravel mass.

"The Valley Gravels.-The valley gravels occupy valleys cut into the Kansan drift. The material for these deposits was released by erosion from the Kansan drift and was accumulated in the valleys during a period of time subsequent to the major erosion of the Kansan drift plain and preceding the deposition of the loess."

18 Carman, J. Ernest, The Pleistocene Geology of Northwestern Iowa: Iowa Geol. Survey, Vol. XXVI, pp. 233-445, 1917. 


\section{Work Published Since 1916}

In Volume XXVI of the Iowa Geological Survey there appeared a report by Alden and Leighton entitled "The Iowan' Drift; A Review of the Evidence of the Iowan Stage of Glaciation". ${ }^{17}$ In this report the authors reaffirmed the existence of a post-Kansan pre-Wisconsin drift sheet in northeastern Iowa and stated that it is younger than the Illinoian and older than the Wisconsin. This essentially reaffirmed the opinion of Doctor Calvin concerning the Iowan drift region and in the opinion of most geologists re-established the Iowan as one of the independent stages of Pleistocene glaciation. It may be well to note here the bearing of this conclusion on the work in northwestern Iowa. During the progress of the work there the Iowan of northeastern Iowa was under severe question and to postulate an intermediate drift region in northwestern Iowa on questionable evidence seemed doubly questionable, for it appeared that it would have to stand without the support of the type, northeast lowa region. Now, with the type region reaffirmed, it would be much easier to put another questionable area, as that in northwestern Iowa, with it.

In 1919 there appeared a report by Leverett and Sardeson entitled "Surface Formations and Agricultural Conditions of the South Half of Minnesota." 18 On the map which accompanies the report there is in southwestern Minnesota an area about 10 miles wide, lying to the southwest of the morainic belt of unquestioned Wisconsin age. At the state line this is the continuation of the intermediate drift region of northwestern Iowa. This belt is mapped as "Till or boulder plains, clayey," a unit which includes also all the Wisconsin ground moraine farther northeast. In discussing southwestern Minnesota they wrote (pages 51-52): "there is a thin sheet of relatively young gray drift, forming a veneer over the eroded surface of the old gray drift, which lies outside the well defined moraine of Wisconsin drift. . . . In the opinion of the present writers, the drift which veneers the eroded district outside of the moraine is not markedly older than that of the moraine of Upham interpreted to be the outer limits of the younger drift, and should, therefore, be included with it." This statement just quoted showed plainly the opinion of Leverett and Sardeson that the "intermediate" area was of Wisconsin age.

In 1922, Leverett, in a paper entitled "Glacial Formations of the

17 Alden, W. C., and Leighton, M. M., Iowa Geol. Survey, Vol. XXVI, pp. 49-212, 1917.

18 Leverett, Frank, and Sardeson, Frederick W., Minnesota Geol. Survey, Bull. 14, 1919. 
Coteau des Prairies,"19 wrote, "A drift of debatable age, but apparently somewhat older than the Wisconsin drift, and referred provisionally to the Iowan stage of glaciation, extends a few miles beyond the undoubted Wisconsin drift in South Dakota, Minnesota, and Iowa and covers the Missouri-Mississippi divide nearly half way across Iowa." On the accompanying map (page 103) Leverett labeled this area "Iowan(?) Drift". This area in Minnesota is the one which Leverett and Sardeson called Wisconsin outside the moraine in 1919 and in northwestern lowa it is the intermediate drift region mapped by the writer in 1913 and called Iowan in the unpublished manuscript of 1915. Leverett had now abandoned, or at least questioned, the Wisconsin age of this area.

\section{Further Studies in Northwestern Iowa}

In the summer of 1925 Doctor Kay was on a trip in northwestern Iowa with Doctors Leverett, MacClintock and Apfel when they found an exposure near Sheldon, in northwestern O'Brien county, which appeared to offer very strong evidence in support of an intermediate drift sheet. This section has been published by Doctor Kay and will be given on a later page of the present report (page 51).

As a result of this trip in northwestern Iowa, and chiefly as a result of finding the section noted above, Doctor Kay asked the writer to return to northwestern Iowa for a field conference with him and for such additional field work as the problem deserved. It was not possible to find a time suitable to both Doctor Kay and the writer until the field season of 1927 .

In the latter part of June, 1927, the writer joined Doctor Kay at Iowa City for this study. They began by a trip over the Iowan of northeastern Iowa, which the writer had never studied. They then spent about two weeks in a review of the evidence for an intermediate drift region in northwestern Iowa. Very few new exposures of any consequence were found, but a number of the exposures studied by the writer in the years between 1910 and 1916 were re-examined in the light of the reaffirmed Iowan of northeastern Iowa and the new interpretations of Doctor Kay concerning the Loveland deposits of western Iowa. As a result of this study it was decided that the evidence was sufficient to justify an interpretation of an intermediate drift region as used in the unpublished manuscript of 1915 .

10 Bull. Geol. Soc. of America, Vol. 33, pp. 101 and 103, 1922. 
It is necessary, therefore, that Chapters III, IV, and V of the report of $1917^{20}$ dealing with the Kansan drift and associated gravels be replaced by chapters dealing with the Kansan drift, Iowan drift and the associated gravels. The present report is, therefore, in large part from the unpublished manuscript of 1915, which recognized an Iowan drift region in northwestern Iowa, modified to include such additional evidence as was obtained in 1916 and in 1927.

20 Carman, J. Ernest, The Pleistocene Geology of Northwestern Iowa: Iowa Geol. Survey, Vol. XXVI, pp. 233-445, 1917. 


\section{CHAPTER II}

\section{THE IOWAN DRIFT REGION}

The region discussed in this chapter is a post-Kansan, pre-Wisconsin drift region lying to the west of the Des Moines lobe of the Wisconsin - drift sheet. It includes most of that questionable area of northwestern Iowa which has been variously interpreted as covered with Wisconsin, extra-morainic Wisconsin, Early Wisconsin, Iowan, or Kansan drift.

The extent of this Iowan drift area in northwestern Iowa is shown on Plate I. It covers the major parts of Osceola, O'Brien and Clay counties, considerable parts of Cherokee, Buena Vista and Sac counties, and smaller parts of Lyon, Dickinson, Sioux and Ida counties. Its total area in Iowa is about 2,000 square miles and its eastern limit is the margin of the Wisconsin drift as traced in the report of $1917 .{ }^{21}$ Its western boundary, to be traced in detail in this chapter (pages 59 to 84), crosses eastern Lyon, northeastern Sioux, southwestern O'Brien, eastern Cherokee, northeastern Ida and southwestern Sac counties, and near the south line of Sac county is overlapped by the Wisconsin drift. The relation of this Iowan region in northwestern Iowa to the drift sheets of Iowa is shown on Plate II. The entire area of this drift region west of the Des Moines lobe is an elongate area extending from Watertown, South Dakota, across southwestern Minnesota and northwestern Iowa to the south border of Sac county, a distance of more than 200 miles. Through Minnesota its width is 10 to 20 miles. South of the state line the belt widens, because of the eastward swing of the Wisconsin boundary, to 45 miles in O'Brien and Clay counties. It narrows again to 15 miles in northern Cherokee and Buena Vista counties and terminates at the south line of Sac county (figure 2).

\section{CORRELATION}

This intermediate drift region of northwestern Iowa is here correlated with the Iowan drift region of northeastern Iowa. A brief statement of the bases for this correlation is given here, but the evidence for the conclusion appears under several headings of this report.

21 Iowa Geol. Survey, Vol, XXVI, pp. 252-293, 1917. 
This intermediate region is younger than the Kansan region to the west and older than the Wisconsin region to the east with its distinctly glacial topography. In contrast with the $W$ isconsin, undrained depressions and other pronounced glacial features are absent. However, the area has not suffered much erosion and some of its features are constructional.

The position of this intermediate drift region to the west of the Wisconsin drift area of north-central Iowa is comparable to the position of the Iowan drift region to the east of the Wisconsin drift area. The two Iowan areas of northeastern and northwestern Iowa together outline the limits of a lobe of ice which covered most of northern Iowa (Plate II). The general features of the topographies of the two regions are the same and the drift of each cannot, in many cases, be positively distinguished from the Kansan drift below. The Iowan area of northwestern Iowa is overlain, without evidence of elapsed time, by a thin mantle of loess or loesslike clay which, as shown in Chapter IV (pages 116 to 136 ), is the time equivalent of the Missouri river loess, which is commonly correlated with the Peorian loess of eastern Iowa, which was deposited soon after the Iowan ice epoch.

The history of the assignment of the intermediate region of northwestern Iowa in the Pleistocene time scale was traced in the review of the literature in Chapter I. The more recent correlations are: in 1919 Leverett and Sardeson placed the corresponding area in Minnesota in the Wisconsin, ${ }^{22}$ and in 1922 Leverett placed the area provisionally in the Iowan. ${ }^{23}$

\section{TOPOGRAPHY}

\section{General Characteristics}

The characteristics which distinguish the Iowan drift topography are faint and rather indefinite, and until they are well understood and their significance appreciated, this drift region may easily escape recognition. In order to appreciate and recognize the differences between the Iowan and Kansan drift topographies, one must stay with the work for sone time, must go back and forth across the boundary from one drift region to the other, and must compare every minute detail. He who expects to see pronounced differences will be disappointed, and he who attempts to verify or disprove must beware of a hasty judgment.

The entire surface of the Iowan drift is in slopes, mostly definite,

22 Minnesota Geol. Survey, Bull. 14, pp. 51-52, and map in pocket, 1919.

23 Bull. Geol. Soc of America, Vol. 33, pp. 101 and 103, 1922 . 
but in some cases so gentle as to be almost imperceptible. The entire surface is therefore drained, although in some places poorly so. The undrained depressions which characterize the Wisconsin drift plain are entirely absent from the Iowan drift, but along some of the stream courses on the upland there are marshy areas, and in several places the Iowan plain is so flat as to be poorly drained.

The topography of the Iowan drift presents considerable diversity, ranging from level plains with a relief of only 10 to 20 feet in half a mile to rolling regions with a relief of 40 to $60 \mathrm{feet}$, and along the larger valleys there are some sharply dissected, rugged areas. The more level areas are chiefly on the great watershed and along the divides between the larger streams in Clay, O'Brien and Osceola counties. Along the larger streams, even in the northern counties, the topography has a moderate relief, and these areas broaden southward at the expense of the slightly rolling interstream areas until the whole is distinctly rolling.

The drainage pattern of the Iowan region is roughly dendritic, and the valleys are relatively broad and straight. A general view from one of the divides where the relief is 20 to 40 feet appears at first to be across an erosional topography, for on either side there may be broad depressions, possibly one to three miles across, and the divides beyond rise essentially to the altitude of the one on which the observer stands. A closer study shows, however, that the slopes are not long, smooth slopes due to erosion but are somewhat uneven and billowy, and the valleys are more or less obstructed. A view across a Kansan drainage basin shows definite locations for the main streams and tributaries, because the slopes are all smooth and the valleys flaring. A view across an Iowan drainage basin does not show the same definiteness of stream courses or smoothness of valley slopes.

It is believed that before the deposition of the Iowan drift this region had an erosional topography developed on the Kansan drift plain, but that along the great divide of the state there were considerable areas that were nearly level as well as more rolling areas farther from the divide. These pre-Iowan features were not completely obliterated by the Iowan drift sheet and still remain as the greater relief features of the region. Upon these larger features the Iowan drift sheet superposed a glacial topography with minor constructional features making inl. even billowy slopes. 


\section{Description of the Topography}

Slightly Rolling Areas.-Most of Osceola county outside the Wisconsin drift boundary is slightly rolling, and the same is true of northern O'Brien county and of western Clay county within the loop of Little Sioux river. On the broader of the interstream spaces some areas are almost level, with a relief of only five to ten feet. A view of one of these level areas in northeastern O'Brien county is shown in figure 4. The largest of these areas is in western Clay county, in Lincoln, Clay and Lone Tree townships, between Willow creek and Ocheyedan river. The surface is so level that the natural drainage is poor, but there is sufficient slope for successful tiling and this is now a very productive farming region. Most of western Clay county within the Ocheyedan-Little Sioux loop has a slightly rolling topography and at many places this comes out to the very edge of the valley, and with its gentle slopes is in decided contrast with the deep, narrow valley of the Little Sioux.

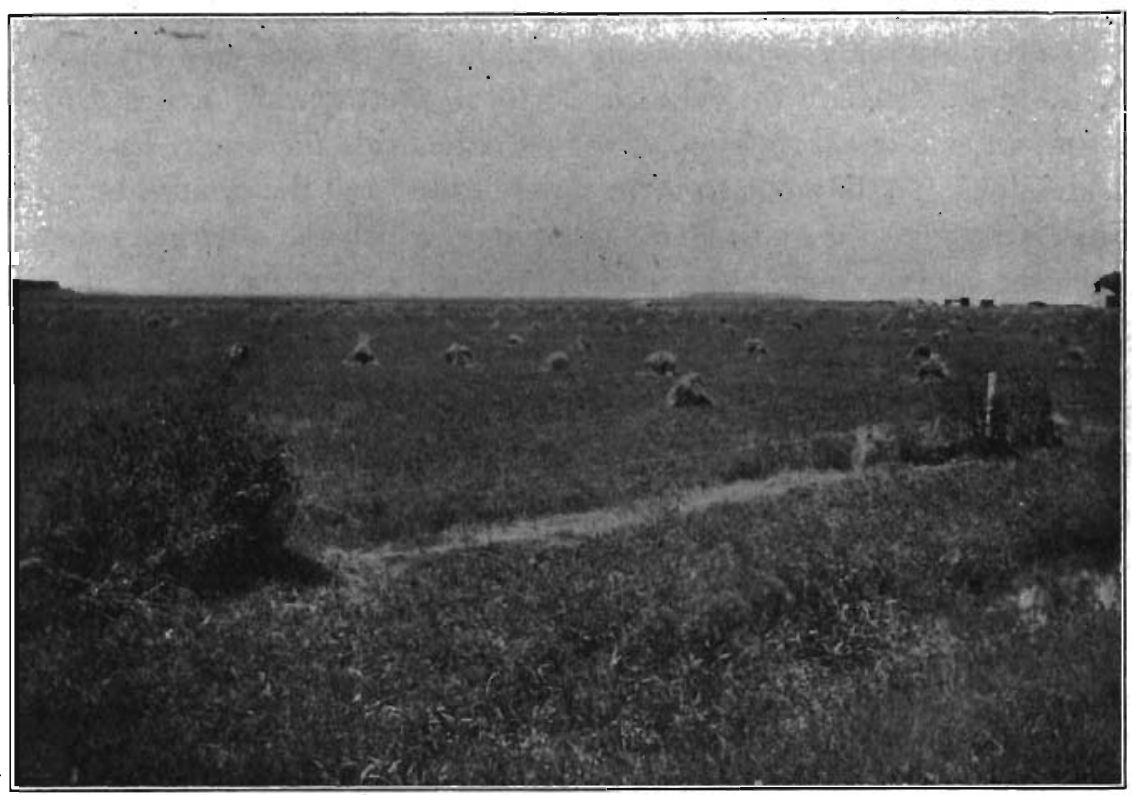

Fic. 4.-View across a level area of the Iowan drift plain northwest of Hartiey in northeastern O'Brien county. (Photo by Lees.)

Another quite level area of considerable size is found along the Osceola-O'Brien county line betweein Melvin and Plessis, and smaller areas exist in north-central Goewey, southeastern East Holman and 
south-central West Holman townships of Osceola county, and in the southwest half of Lincoln township, O'Brien county. From the large area of slightly rolling topography of northern O'Brien county narrowing areas extend southward along the divides between the Floyd river and Mill creek valleys and between the valleys of Mill and Waterman creeks.

A very level area lies just south of the Wisconsin drift boundary of southwestern Dickinson and southeastern Osceola counties, and similar though smaller areas exist east of Little Sioux river from Milford to Dickens and to Gillett Grove. The evenness of some of these areas may have been accentuated by the outwash from the Wisconsin ice front, but they apparently were level before the Wisconsin epoch.

North of Spencer in the adjoining corners of Sioux, Meadow and Summit townships is probably the flattest area of the Iowan drift plain. It is but little above the Little Sioux valley to the southwest, and is so level as to be poorly drained. The poor drainage of this district is due partly to a low ridgelike belt of sand hills along the edge of the Little Sioux flat which has obstructed the drainage from the north (page 47).

Moderately Rolling Areas.-Within the slightly rolling areas of Osceola, O'Brien and Clay counties there are more strongly rolling belts along most of the larger valleys. These broaden southward along the valleys until the intervening, slightly rolling areas are entirely eliminated. Along some of the valleys, as the Little Sioux below Gillett Grove, and the Waterman, a sharply dissected topography exists.

Most of the more rolling topography lies along the valleys, but there are some areas on the upland entirely surrounded by the slightly rolling topography. Such areas are found in north Goewey and Gilman townships of Osceola county and along the headwaters of Floyd river on the county line northeast of Sheldon. Another area lies between the Little Ocheyedan and the Ocheyedan valleys in southeastern Osceola county and is continued as a narrow belt southward along the west side of the Ocheyedan and Little Sioux valleys.

The Iowan drift region of eastern Cherokee, western Buena Vista. western Sac and northeastern Ida counties is, in general, moderately rolling but includes small patches of but slightly rolling topography. The general relief is 30 to 50 feet and the region is well drained. It is an erosional topography mantled by a thin sheet of Iowan drift. 
Erosional Topography along Valleys.-Along some of the larger valleys of the Iowan drift region there are areas characterized by sharp dissection and considerable local relief, giving a very rugged topography along the valleys, although the inter-stream areas present rounded slopes and slight relief. This topography is found along the Little Sioux valley in northeastern Cherokee, southeastern O'Brien, and southern and eastern Clay counties. It exists also along the lower courses of the larger tributaries of the Little Sioux, as Mill, Waterman, Willow and Brooke creeks (figure 5). It has its greatest development in northeastern Cherokee and southeastern O'Brièn counties, where Little Sioux river is 175 to 200 feet below the upland, and where many small tributaries have cut three to five miles into the upland, producing a much dissected area with a relief of 125 to 150 feet. The slopes are steep, but the divides are level and project as spurs of the upland between the ravines out to the very edge of the Little Sioux valley.

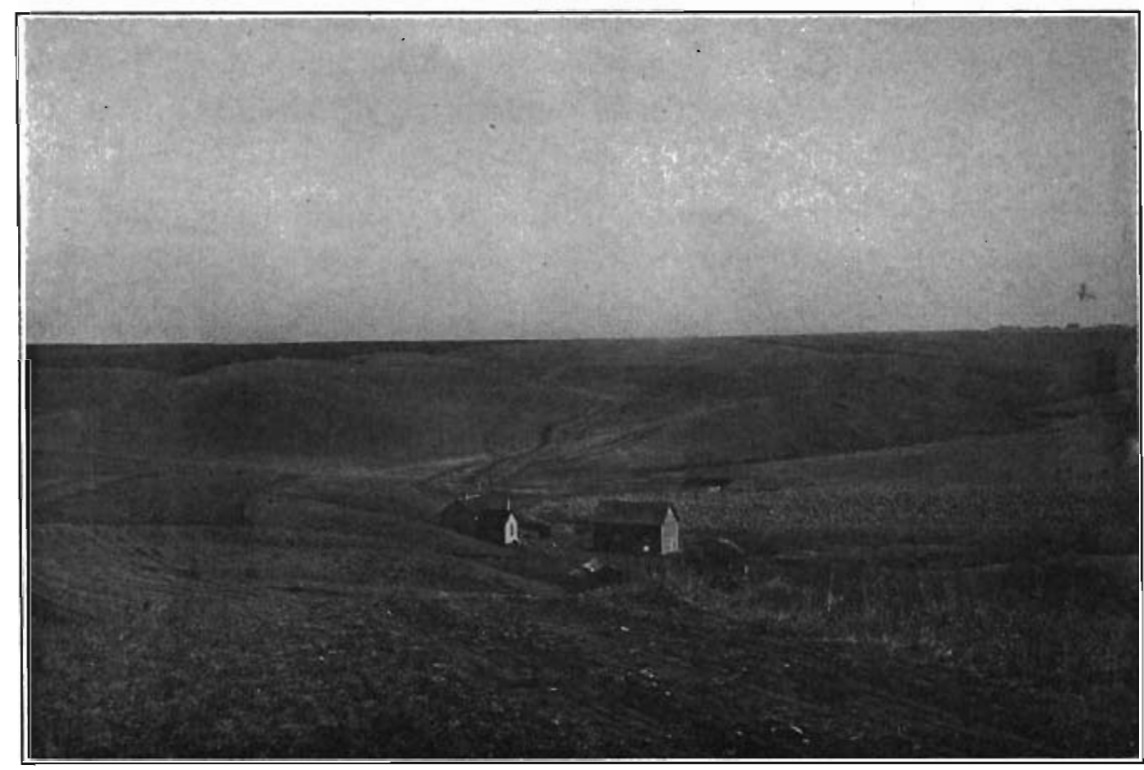

FIG. 5.-View across a sharply dissected area of the Iowan drift region in the lower course of Brooke creek in northwestern Buena Vista county. (Macbride, Iowa Geological Survey, volume XII, p. 315.)

East of southeastern O'Brien county the sharply dissected belt along the Little Sioux valley is narrower, and at many places the slightly rolling plain comes up to the very edge of the valley. Good examples of this condition exist on either side of the valley in the sotthwest 
corner of Clay county, in Gillett Grove township of eastern Clay county, opposite Sioux Rapids and elsewhere. Notably sharply dissected areas are present southeast of Cornell in Herdland township, in section 4 of the same township, in section 27 of Peterson township and at other places.

The area of sharply dissected topography along the Little Sioux valley is more extensive at the mouths of the tributary creeks, and extends up the larger of these creeks for a number of miles. It extends several miles up Willow creek valley in south-central Clay county but with decreasing relief and ruggedness. It continues up Brooke creek valley (figure 5) in northwestern Buena Vista county for about four miles and up other smaller creeks to the northwest of Brooke creek through the north-central part of Brooke township. In southeastern O'Brien county where this sharply dissected topography is so well developed along the Little Sioux, it continues up Waterman creek valley for seven to eight miles through central Grant township. The dissection here is remarkably sharp, giving a topography that is in striking contrast with the level upland to the east and west. The sharply dissected topography extends six to eight miles up Mill creek valley in Cherokee county and affects the lower courses of its tributaries.

If they are viewed from a distance, most of these tributaries of the Little Sioux appear to have broad shallow valleys, but as they are approached more closely what appeared to be broad shallow valleys are found to be trenched by narrow steep-sided valleys. (figure 6).

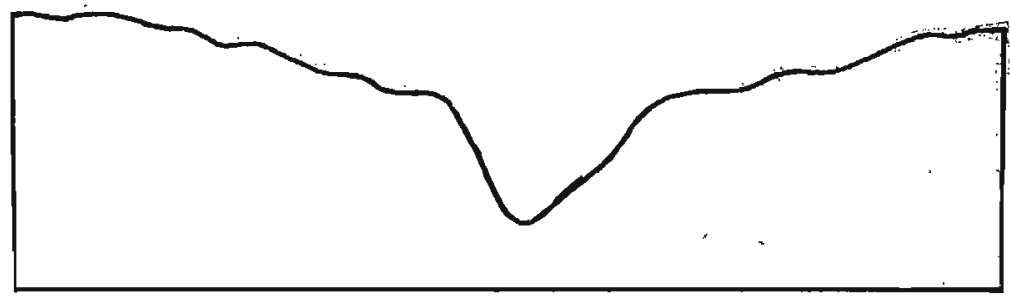

FIG. 6.-Cross profile of a tributary valley of the Little Sioux showing the trenchlike inner valley cut into the broader outer valley.

This feature is particularly prominent in the lower courses of the tributaries. Farther up these creeks the narrow valleys in the bottoms of the older ones grow shallower until they terminate, and above their upper ends the streams flow through broad, shallow valleys similar to the wider parts of the valleys farther down stream. The valley of a small creek which joins Mill creek in section 10 of Cherokee township, 
and which is followed by the Illinois Central railway northward toward Larrabee, shows well the passage from the sharply dissected topography to topography of the upland type. In its lower course the inner valley is 60 to. 75 feet deep, but northward it becomes shallower until at Larabee it terminates, and north of this place the stream flows in a broad, shallow valley characteristic of the Iowan upland.

When the Ocheyedan-upper Little Sioux system was thrown southwestward across the great watershed into its present course, ${ }^{24}$ new conditions were established, and the great quantity of water carried by the Little Sioux soon deepened its valley notably and destroyed the adjustment between it and its tributaries. The rejuvenated tributaries and the valleyside gullies then began to carve out the sharply dissected topography described above. This sharp dissection is all the work of post-Wisconsin time, and cutting in the tributary valleys is still in progress.

Aggraded Areas.-At several places within the Iowan region there are almost level areas that have been formed by the filling in of low areas with gravel. A good example is found west of Primghar in central O'Brien county, where several branches of Mill creek unite (page 157). Here a level area several square miles in extent is almost wholly underlain with gravel. Another lies east and southeast of Sibley in East Holman township, Osceola county, where areas extending some distance back from the present valleys are underlain with gravel (page 143).

Gravel Hills.-At various places on the Iowan plain there are gravel hills or mounds hardly distinguishable from the usual features of the region. Some of them are in groups, some are in rows along the upland valleys, and some are single isolated hills. In the northeast corner of Lyon county north and west of Little Rock there is a group of these hills, giving a topography that is plainly constructional. Along the course of Willow creek leading west from Calumet in southern O'Brien county there is a row of them. Others either in small groups or as single hills are well distributed over the entire Iowan drift plain. These kamelike hills are more fully treated on pages 90 to 102 .

Gravel Benches.-Gravel benches exist along most of the valleys of the Iowan drift plain. Some of them are conspicuous topographic features, as they are continuous for great distances and stand well

24 Iowa Geol. Survey, Vol. XXVI, pp. 310-318, 1917. 
above the level of the streams, but some are merely inconspicuous remnants of terraces or shoulders on the valley sides. They are most prominent along the Little Sioux through Cherokee county and in the lower courses of Mill and Waterman creeks. The dissection of the benches is, as a rule, much sharper than that of the uplands, being of the sharply dissected type of topography described above (pages 44 to 46). All the small creeks cross these gravel areas in narrow, steepsided valleys while upstream on the upland they may have broad, open valleys. Even the smaller valleys of the Iowan region generally have gravel deposits along their courses, even out near the heads of small streams on the upland. Benches may or may not be present, depending upon the extent to which the stream has cut into the valley filling. The valley gravels are discussed more fully in Chapter V.

Sand Hills North of the Spencer Flat.-At a number of places along the north side of the Spencer flat there is a topography characterized by low rounded hills, with a relief of only 10 to 20 feet. These hills appear at first sight to be glacial, but a closer examination shows that they consist largely of sand and that sandy roads are common in the belt where they are present. As noted on page 43 the poor drainage of the plain just north of Spencer apparently is due in part to obstruction caused by this low ridgelike belt of hills.

This topography begins at the east end of the Spencer flat just west of Meadow brook and extends westward as a low slightly rolling ridge bordering the flat through the north half of section 9 , the south half of section 5 , and the central part of section 6 of Sioux township. It is present in section 1 of Riverton township and in the north half of section 36 and the northeast quarter of section 35 of Summit township, where some shallow road cuts show exposures of sand. The north half of section 32 and the adjoining parts of sections 29 and 30 , Summit township, on the point of upland between the Little Sioux and Stony creek valleys, have a topography of slightly rolling hills with a relief of about $10 \mathrm{feet}$, and the road on the north line of section 32 is quite sandy. Similar topography and sandy roads are found just north of Everly, and in section 33 and the southwest quarter of section 28 of Waterford township are rounded hills half a mile back from the valley which are said to be composed of sand. Farther northwest at the southwest corner of Osceola county, along the east bluff of the Ocheyedan river valley, there is another belt of low rounded hills composed of sand, and similar features are shown faintly northwest for several miles across Harrison township. 
The distribution of these sand-areas to the north of the Spencer flat and to the northeast of the Ocheyedan valley accords with the usual location of eolian deposits on the northeast side of vallevs, due to the prevailing southwest winds of our latitude. They probably were formed during the Wisconsin glacial epoch when Ocheyedan river was carrying great floods of debris-laden water from the margin of the Wisconsin ice sheet.

All these areas of sand hills are along the course of the "Altamont moraine" as mapped by Professor Macbride in his discussion of "The Margin of the Wisconsin Drift." 25 They resemble a faint glacia! topography and may have been so interpreted by Professor Macbride.

\section{THE IOWAN DRIFT}

\section{General Characteristics}

The differentiation of the Iowan drift region as distinct from the Kansan and the Wisconsin is based primarily on its topography. The characteristics of the drift itself are so like those of the Kansan drift that general descriptions of the two would be almost identical. It is only by comparing them in detail that differences and distinguishing characteristics can be made out. There are some places where the upper part of a section of drift is fresher than the lower part or differs in some other way, and in such places a twofold division of the drift is suggested.

The more general characteristics of the Iowan till are as follows: It has a brownish gray color where fresh, and on the faces of dry cuts the color is yellowish gray, somewhat lighter than the Kansan till under similar conditions. It is strongly calcareous, even to the surface, there being no leached zone, but near the surface many of the cuts are characterized by a gray calcareous staining along joints and in streaks and blotches through the till, the beginning of alteration. The Iowan till is more sandy and pebbly than the Kansan and, therefore, less compact. Where it is most compact it breaks out in angular chunks which crush down to a mealy clay. The dominant pebble is gray limestone which is, as a rule, fresh and unaltered, although some of the associated coarse-grained igneous pebbles are rotted so as to crumble easily. A common feature is the presence of small, brown, ocherous grains from a sixteenth of an inch to an inch across.

Since the Iowan till generally cannot be separated in sections from

25 Iowa Geol. Survey, Vol. XII, pp. 329 and $333,1901$. 
the Kansan beneath, few data exist as to its thickness. Some of the sections to be given later show 20 to 30 feet of what may be Iowan till, and even more where interbedded with gravel; but it is probable that over most of the area concerned the Iowan till is relatively thin, and that it is in large part reworked Kansan till.

A pronounced characteristic of the till of the Iowan region is its association with much gravel. Some of the gravel is in masses in the till, some is at the surface of the till, some is in layers interbedded with the till, and some is in bedded deposits in the valleys. The gravel in these several positions is very similar and appears to have had a common origin.

\section{Relation to the Loveland Deposits}

There are very few exposures of Iowan till associated with other deposits in such a way as to fix the age of the tills. The super-Kansan gumbotil, which forms such a definite key horizon in the Iowan region of northeastern Iowa and in southern Iowa, is not present in northwestern Iowa and there are no other similar, widely distributed interglacial deposits. It is this lack of key horizons that has made it so difficult to conclusively establish the existence of the Iowan drift region.

At various places in western Iowa south of our region there are old loess, silt, and sand deposits younger than the erosion of the Kansan till and older than the general loess horizon of Peorian age. - These are known as the Loveland, a term introduced by Shimek in $1909^{20}$ and more definitely defined and limited by Kay in recent years. ${ }^{27} \mathrm{Kay}$ has now recognized this unit at various places in southern Iowa, beneath the Iowan till of northeastern Iowa and between the Illinoian gumbotil and the Peorian loess of southeastern Iowa. So far as western and southern Iowa are concerned the Loveland could be late Yarmouth, Illinoian, Sangamon or Iowan in age, but the relations in eastern Iowa, where it rests on an eroded surface cut in the Illinoian gumbotil in southeastern Iowa and is overlain by the Iowan till in northeastern Iowa, seem to limit it to late Sangamon time. It is, of course, not necessary that all deposits called Loveland be of exactly the same age.

Deposits which are interpreted as Loveland have been found at sev-

20 Bull. Geol. Soc. of America, Vol, 20, Footnote, p. 405, 1909

$27 \mathrm{Kay}, \mathrm{G}$. F., Recent Studies of the Pleistocene in Western Iowa: Bull. Geol. Soc. of America, Vol. 35, pp. 71-73, 1924. Loveland Loess; Post-Illinoian, Pre-Iowan in Age: Science, N. S., Vol. LXVIII, pp. 482-483, 1928. Significance of Post-Illinoian, Pre-Iowan Loess: Science, N. S., Vol. LXX, pp. 259-260, 1929. Also Iowa Geol. Survey, Vol. XXXIV, pp. 277-281, 1929. 
eral places in northwestern Iowa and the horizon will appear in some sections treated under the discussion of the loess (pages 126 and 130) and in some sections treated under the discussion of the Iowan boundary (pages 73 to 78 ). A few deposits interpreted as Loveland have been found in the Iowan region beneath till which is in turn overlain by the Peorian loess, and these sections, if correctly interpreted, fix very definitely a post-Loveland, pre-Peorian till. These are, therefore, the most important exposures in support of an Iowan drift region.

In the south part of section 19, Cedar township, Cherokee county, the road cut on the south slope of a deep, narrow ravine showed the following :

FEET

4. Clay, loesslike. Peorian ......................... 4

3. Till, brownish gray, sandy, pebbly, unleached. Iowan ........... 8

2. Sandy silts, blue-gray, calcareous. Loveland .............. 8

1. Till, brown, unleached in upper part, blue-black below. Kansan ..... 45 Top few feet exposed in road cut and exposures exist at intervals down the ravine to near Mill creek.

The road cut on the north slope of this ravine, 50 yards from the above exposure, showed the following:

3. Gravel fresh unleached

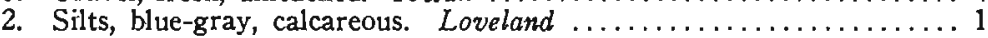

1. Till, brown, unleached. Kansan ....................... 4

The blue-gray calcareous silts on the south side of the ravine very definitely separate a thin till above from a thick till below. These silts are of the type generally recognized as Loveland, and the upper, lighter colored till must be Iowan. On the north of the ravine the Iowan till is absent but the characteristic fresh Iowan gravels occupy this horizon. These exposures are near the boundary of the Iowan drift region as mapped.

At the southeast corner of section 13, Liberty township, Cherokee county, a road cut on the east slope of Mill creek valley showed the following :

3. Silty material, unleached, blue-gray, with some oxidized sandy layers.

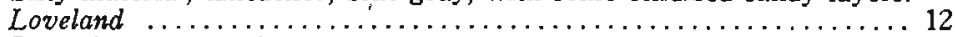

2. Loesslike clay or silt with some sandy layers, brownish. Loveland. 12 As a whole it seems to be leached but has a few calcareous concretions in the upper part. Locally it is strongly oxidized.

1. Till, brown, oxidized, unleached. Kansan ................ 25 This continues below the road level down to the creek. 
A road cut just north of the southeast corner of the section, just north of the east end of the above exposure, showed the following:

FEET

5. Clay, loesslike. Peorian ............................. 5

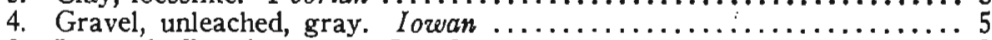

3. Loess, buff, calcareous. Loveland ...................... 8 Somewhat banded with bluish and brownish bands. A few snail shells were found on the slope.

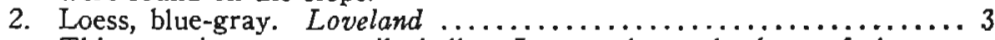

This contains many snail shells. It extends to the base of the cut.

Numbers 3 and 2 of this section are the equivalent of number 3 and possibly number 2 of the first section. Number 5 is above the first section, and the second section does not reach number 1 of the first section. These exposures are at the edge of the Iowan drift sheet as mapped. No Iowan till is shown, but the gravel is a well recognized horizon of this age.

A section west of the quarter-corner on the south of section 4, Carroll township, O'Brien county, three miles southeast of Sheldon, is recorded by Kay and Apfel as follows ${ }^{28}$ :

3. FEeT

2. Till, Iowan, highly calcareous, pebbly and sandy, oxidized to yellowish brown color ............................. 2 to 3

1. Loess, Loveland, highly calcareous, plowed into base of till, gray

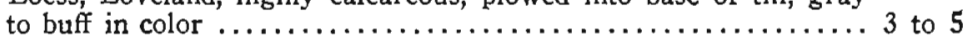

This exposure was found by Kay, Leverett, MacClintock and Apfel in 1925 when the section quoted above was taken. The writer visited this exposure in 1927 in company with Kay, at which time it was so badly slumped and so overgrown with weeds that the above section could not have been made out. However, the several units were dug out locally so that one could recognize at top a leached buff loesslike clay; lower down a calcareous, sandy or gravelly till-like material; and lower still a gray loesslike clay. The writer accepts the interpretation given by Kay and Apfel for this section.

The highway ascending the east bluff of the Little Sioux valley just east of Cherokee showed, in 1927, an interesting series of cuts. The ascent to the upland is made along a grade which cuts a series of spurs between ravines and fills the ravines, and the cuts are successively higher to the east. The first two cuts, beginning at the lower or west end, showed gray unleached Nebraskan till grading upward to leached Nebraskan till or gumbotil. The second cut showed an irregular contact

28 Iowa Geol. Survey, Vol. XXXIV, p. 279, 1929. 
with the Kansan till above, owing to the plowing up of the Nebraskan till by the Kansan ice. This plowing has removed the weathered $\mathrm{Ne}$ braskan at some places.

The third cut from the west showed the following section:

4. Clay, loesslike

At crest of cut it is one foot thick and leached. It thickens down the slopes of the cut to 3 feet, with a maximum leached zone of 2 feet.

3. Till, friable, sandy. Apparently Iowan ..................... 13 At top is a pebble band with several cobbles of quartzite that show wind polish.

2. Till, yellow-brown, unleached, Kansan ................. 20 Contains several inclusions of Nebraskan till.

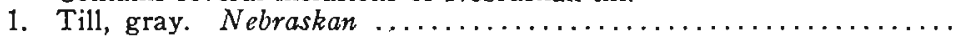

The fourth cut showed only Kansan till. The fifth cut showed 17 feet of buff and blue horizontally bedded silty material with some sandy layers and a few pebbles. It is all calcareous. In the lower part of the exposure at one place is a carbonaceous soil-like material in which a few shell fragments were found. The cut exposed nothing above or below this material, but the elevation of the cut is entirely covered by the Kansan till horizon of the next cut on the west and the next cut on the east. The silty material evidently occupies a depression in the general horizon of the Kansan till. It is interpreted as Loveland material and may be in part eolian.

The next cut exposed 15 feet of oxidized Kansan till overlain by two feet of fresh Iowan gravel and then by four feet of Peorian loess leached to a depth of two feet. The cut at the crest of the valley slope showed about seven feet of loess leached to a depth of four feet. Below the loess about four feet of yellow pebbly till was exposed and the lower part of this horizon showed a much contorted unit of silty material six to twelve inches thick mixed with the till. The till is apparently Iowan, enclosing in its base some contorted Loveland silts.

This series of cuts exposes from the base upward, Nebraskan till, Nebraskan gumbotil, Kansan till, Loveland silts, Iowan till and gravels, and Peorian loess. They are located approximately at the Iowan boundary.

\section{Some Till Exposures Interpreted as Iowan}

Aside from the exposures described above, which include Loveland deposits, the best evidence for the recognition of an Iowan till is found in northern Cherokee county along the Little Sioux river and 
Mill creek valleys, and many exposures of this region were studied in detail. Some of the better ones of these exposures will be described.

Doupe Farm.-There are several interesting exposures on the farm of M. Doupe, in the north half of the northwest quarter of section 13, Cherokee township. A sketch map of the area is shown in figure 7. The upland

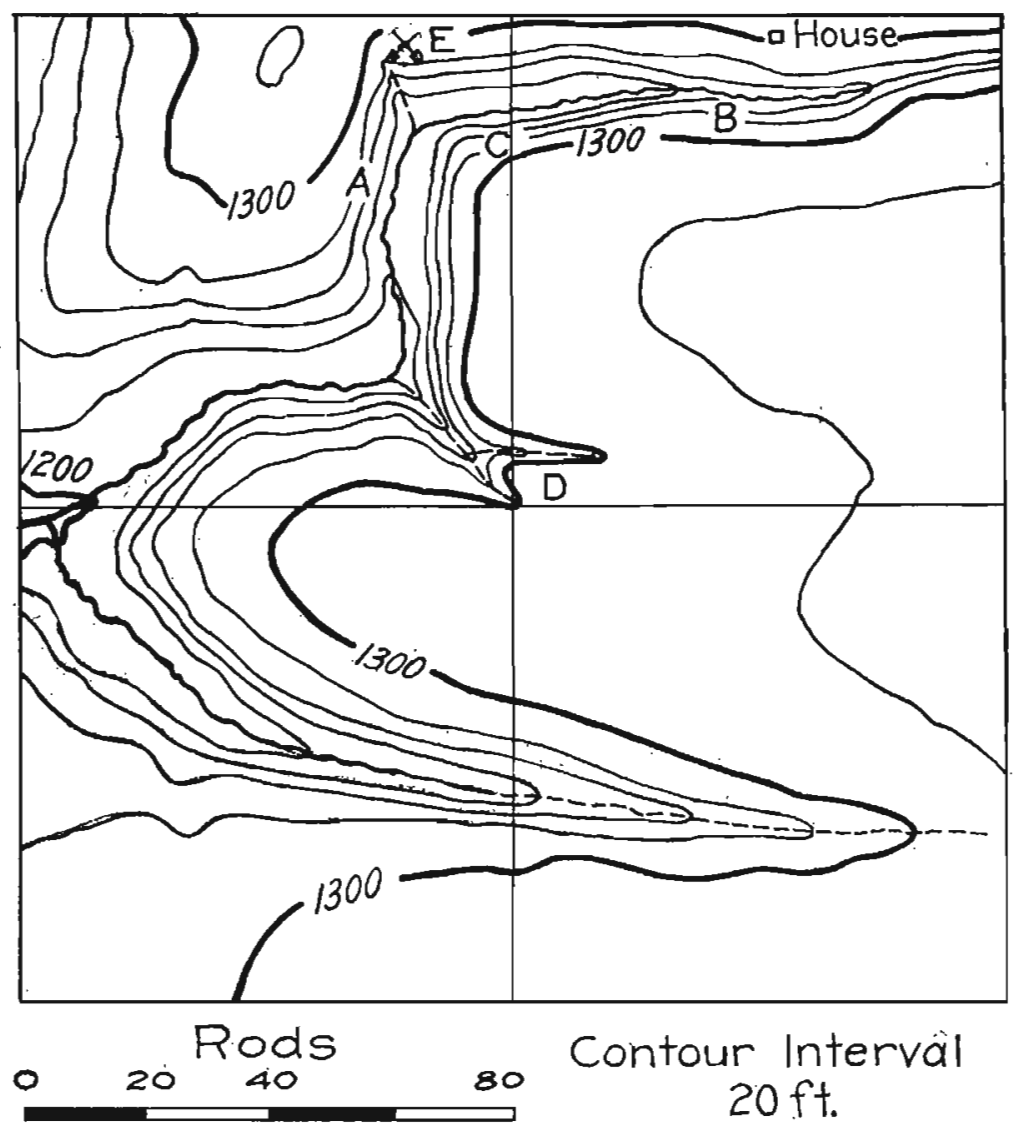

Frc. 7.-A sketched contour map of the northwest quarter of section 13, Cherokee township.

level over most of this quarter section is a bench at an elevation of about 1300 feet above sea level. A ravine enters near the northeast corner and runs southwest across the quarter section as shown in figure 7 . Where it enters the quarter section, this valley is only 25 to 35 feet deep, but in the next quarter of a mile it deepens abruptly so that across the west half of the quarter section it has a depth of 80 to 100 feet, and a narrow floodplain indicates that the stream has here reached grade. The valley sides 
are very steep for drift slopes and rise directly to the level of the bench. This valley is a good example of the type of recent dissection found along the Little Sioux.

The west slope of the valley, about 20 rods south of the place where the stream turns south in the north part of the quarter section (A, figure 7), exposed, in 1910, the following section. It is shown diagrammatically in A of figure 8.

D

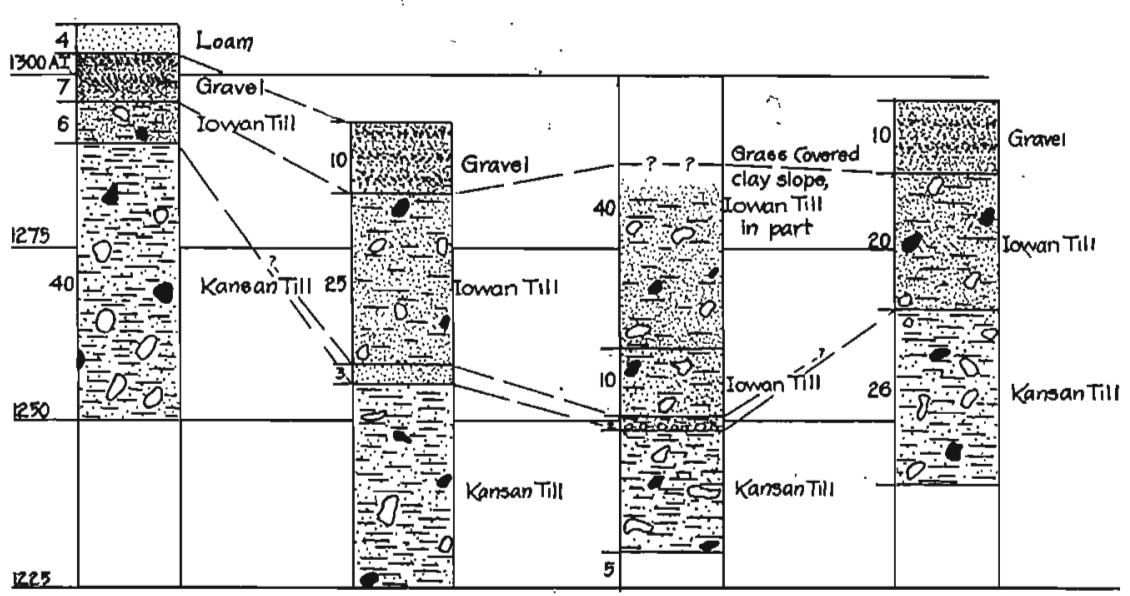

Fig, 8.-Columnar sections of exposures on the farm of $M$. Doupe in the northwest quarter of section 13, Cherokee township. The locations of the sections are shown by corresponding letters on figure 7 .

4. Gravel horizon below terrace bench $\ldots \ldots \ldots \ldots \ldots \ldots \ldots \ldots \ldots$

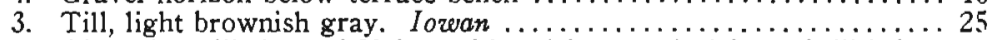

Above is a till slope of 20 feet with a 5 -foot vertical face of till below. This till is more sandy and pebbly than the Kansan and therefore less compact. The lower part contains several lenses and seams of sand.

2. Sand, dirty, yellow, fine- to medium-grained, with a few pebbles and

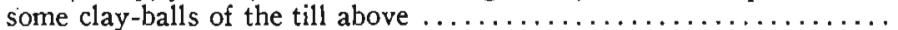
The contacts with the Kansan below and the Iowan above are sharp and horizontal, and the horizon has a uniform thickness across the exposure, a distance of about 40 feet.

1. Till, dark blue, tough, pebbly, weathers brown. Kansan ........ 25 At the top is a vertical face 10 feet high. Below this, a slumped slope of weathered brown till continues down 20 feet to the ravine bed.

About 20 rods southwest of the Doupe farmhouse, at the point marked $B$ in figure 7 , the south slope of the ravine showed the typical dark brown Kansan till rising 25 feet above the ravine bed and overlain directly by the Iowan till, a light brownish gray sandy till with brown iron staining along the joints. This upper till breaks out in angular chunks which break 
up further into small angular fragments and pulverize to a sandy clay. If quite moist the till is plastic, but the sandy nature is usually evident. Sandy or gravelly material is mixed with the till at several places and both the till and the gravelly material have many limestone pebbles. As at many other places a prominent character of the Iowan is the presence of small reddish brown ocherous grains which pulverize to a reddish brown powder. The Iowan till was freshly exposed for about 12 feet and a till slope rose eight feet higher, giving a total thickncss of 20 feet. The till was overlain by 10 feet of fresh gravel rising to the terrace level. The columnar section is shown in B of figure 8. The contact of the Iowan and Kansan tills was exposed at three places covering a distance of about 20 feet and in this distance drops about one foot. At one of the places exposed there is a thin seam of sand at the contact, and at another a zone about one foot thick which is a mixture of the tills above and below. Where no contact phenomena appear, the contact is still distinct, by reason of the contrast of the two tills.

The south slope of the valley on the center line of the quarter section (C, figure 7) exposed the following section, which is shown diagrammatically in $\mathrm{C}$ of figure 8 .

4. Pebbly slope with a few exposures of till and sand ........... FEE

This zone appeared to consist of till with several large included masses of sand. The upper part of this slope covers the elevation of the usual gravel horizon beneath the terrace.

3. Till, brownish gray, sandy, with lenses of sand. Iowan ......... 10

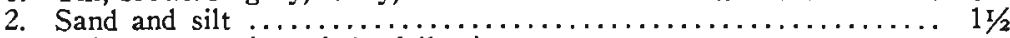
This zone consists of the following:

c. Coarse, ferruginous, laminated sand with a thin band of

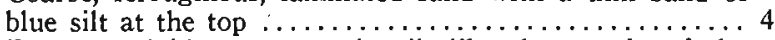

b. Brown and blue-gray sandy silt like the matrix of the layer below ............................... 6

a. Blue-gray sandy silt with cobbles and some bowlders up to 10 inches in diameter $\ldots \ldots \ldots \ldots \ldots \ldots \ldots \ldots \ldots \ldots . \ldots . \ldots . \ldots . \ldots . \ldots$
The bowlders lie on the Kansan till surface and the silt was apparently put down around them.

1. Till, mottled brown and bluish brown. Kansan ............... 18

This type of till is produced by the rapid weathering of the blue clay. The upper three to four feet was in a cliff exposure. The remainder was in a slumped slope extending down to stream level.

The sand and silt zone (No. 2) was exposed at another place in the slide 25 feet away and showed approximately the same succession of bowlders, silt and sand, but all somewhat more ferruginous. The undisturbed position of the laminæ of sand and the silt band just below the upper till show that there was little wear or shoving by the Iowan ice, for such delicate structures would be difficult to preserve even if the material were firmly frozen. 
While ascending the small ravine which heads at the center of the northwest quarter of section 13 ( $D$, figure 7 ) many exposures of typical brown Kansan till were seen, through a vertical distance of $40 \mathrm{feet}$, and at the head of the ravine the Iowan-Kansan contact was exposed at several places over a distance of 25 to 30 feet horizontally. The two tills are in direct contact or separated by a thin band of ferruginous sand.

The Iowan till of this exposure is only a few feet thick, but aside from some slight surface alteration and discolorations along the contacts it has the characteristics common for this till. It contains much coarse yellow sand and gravel, and at one place a vertical section showed as much sand and gravel as till. At the top of the till there is, at several places, a zone 6 to 18 inches thick that was either laid in water or partly reworked. The till is overlain by terrace gravels, and along the contact both the basal six inches of the gravel and the top six inches of the till are iron stained.

The terrace-gravel horizon is six to eight feet thick in this exposure and consists of fresh fine-grained gravel with many pebbles, cobbles and bowlders distributed through it. Gray limestone is particularly abundant among the pebbles. The gravel is in turn overlain by dark brown noncalcareous loesslike clay which has a thickness of about four feet and stands with a vertical face which shows columnar jointing. A columnar section of this exposure is shown in D of figure 8.

Besides the exposures already described for the Doupe farm, there are a number of other smaller exposures supplementing and confirming those already noted. At the gravel pit ( $E$, figure 7 ) the Iowan till and overlying gravels are shown. The road cuts along the north line of the quarter section west of the Doupe farmhouse showed a light yellowish gray till that was distinctly lighter than the Kansan till. The upper few feet of this till contain considerable whitish calcareous material along the joints and in streaks through the till. Where the road crosses the ravine, east of the Doupe farmhouse, in the northwest corner of the northeast quarter of section 13, both valley slopes show the Iowan till overlain by valley gravels.

Pits of Cherokee Sand and Gravel Company.--Across the Little Sioux valley from the Doupe farm, in the northwest quarter of the northeast quarter of section 14, Cherokee township, are the gravel pits of the Cherokee Sand and Gravel Company, in the terrace of the Little Sioux valley. Several pits have been worked in the past on the slopes of a ravine that cuts into the terrace and a pit just south of the ravine was operated to a depth of 40 to 50 feet. All the pits show essentially the same succession. At the top is a gravel horizon a few feet thick; then comes a till horizon 
four to seven feet thick; and below this is the great gravel horizon which has been worked to a depth of more than 50 feet.

Three abandoned pits, each 75 to 100 yards from the others, are located on the slopes of the ravines, as shown in figure 9. The till horizons of the

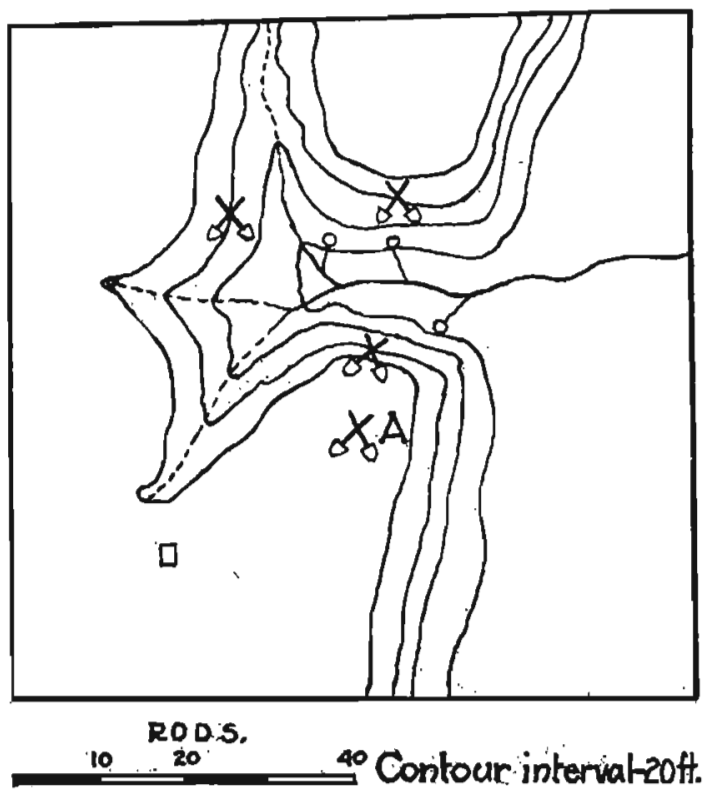

FIG. 9.-Sketched contour map showing the location of gravel pits on the farm of F. R. Turner (northwest quarter of the northeast quarter of section 14, Cherokee towriship). The pit $A$ was operated by the Cherokee Sand and Gravel Company.

three exposures are of practically identical material, are at approximately the same altitude, and have the same thickness, so that there can be little doubt that the till was once continuous across the intervening valleys over an area at least 75 to 100 yards across. The mass is too large to have been floated in by ice and must have been laid directly by the Iowan ice sheet. The till horizon is thinner in the pit on the terrace just south of the ravine and is said to be absent entirely beneath the terrace a few rods farther south.

This till has a light brownish gray color, shows brown iron staining along the joints, and contains many small, reddish brown ocherous grains. Pebbles and cobbles are scattered through the till. Limestone is the dominant material among the pebbles, and it is mostly fresh and firm, while the coarse-grained igneous pebbles are decomposed and crumble easily. These several till exposures differ slightly because of different conditions of moisture, exposure, etc., yet in the main they are similar and all have the characteristics of the Iowan till. 
The contact of the till with the gravel below is very sharp and there is no alteration whatever, both the till and the gravel being distinct to the very plane of contact. In one exposure, extending 30 to 40 feet horizontally, a six-inch layer of coarse sand underlies. the till directly and yet not the least distortion or mixing is shown. The contact does not appear to have been produced by planation by the ice and may represent an aggraded surface covered by till without disturbing the material below. The contact of the till with the gravel above is not so well shown as is the lower contact, but enough was seen to show it has some irregularities. The overlying gravel, where thin and coarse, is weathered and iron-stained throughout its entire thickness.

Other Exposures.-In the east bluff of Mill creek valley in the west half of section 14, Cherokee township, there are a number of exposures showing gravel and till interbedded. The till in the upper, steeper part of the bluff is Iowan, a brownish gray or brownish yellow clay with pebbles, cobbles and small ocherous masses. These exposures are more fully discussed on pages 84 to 89 .

Many exposures north of the Cherokee region show a till that is not typical Kansan, and yet from the small exposures it was seldom possible to identify them positively as Iowan till. They are numerous in northeastern Cherokee, southeastern O'Brien, southwestern Clay and northwestern Buena Vista counties, and less abundant elsewhere throughout the Iowan region. Many of them will be noted in connection with the tracing of the Iowan drift boundary.

In Spring township of northeastern Cherokee county the brownish gray Iowan till was seen on the south lines of the southeast quarter of section 31 and the southwest quarter of 32 ; along the road leading down to the Little Sioux valley north of the center of section 29, where a 15-foot exposure of Iowan till rests on a sand horizon containing a lot of clay masses; in the upper part of the bluff south of the center of section 21 , where it is apparently 50 feet thick; and in the west part of section 12, 75 to 100 yards southeast of the point where the road crosses the creek, the east slope of the valley shows at the top about 40 feet of Iowan till resting on sand, while Kansan till forms the lower part of the slope.

In Brooke township in northwestern Buena Vista county examples of fairly definite Iowan till were seen in road cuts on either slope of a ravine near the quarter-corner on the south of section 22 , in the road cut at the top of the east bluff of Brooke creek on the north line of section 25, and in the cuts on the east of sections 17 and 8 . The west bluff of Brooke creek on the north of section 23 showed a mixture of sand and possible Iowan till. 
Probable Iowan till was seen in shallow cuts in various parts of $\mathrm{O}^{\prime} \mathrm{Brien}$ county. Along Willow creek in Liberty township such exposures were found in the south bank of the creek at the southeast corner of section 17 and in the road cut just east of the quarter-corner on the south of the same section. The road cut in the south slope of this valley on the west line of section 20 showed the typical brownish gray Iowan till, with much gravel interbedded and in pockets, while down the slope near the creek and north of the creek a yellowish brown till that is apparently Kansan was exposed. Probable Iowan till was seen in the railway cuts of section 6 and 7, Highland township; as material thrown from a well in the southwest quarter of section 31, Summit township ; in excavations at Hartley ; and at many other places.

West and northwest of Sheldon there are several exposures of probable Iowan till which will be noted in tracing the Iowan drift boundary (page 65). The till exposed in excavations at Sibley is very fresh and, in fact, this is the general condition everywhere in the northern part of the Iowan drift area.

South of the Wall Lake outlet in southern Sac county, in the banks of a small creek valley which follows the Wisconsin drift boundary in the west part of section 20, Viola township, two tills are exposed. The lower is Kansan. The upper has a yellowish gray color where dry and brownish gray where moist. It breaks into flakelike pieces, crumbles to a mealy clay and contains many more pebbles than the Kansan. Its contact with the Kansan below is relatively sharp and it has a thickness of more than 20 feet. This till is almost identical with the till that overlies the Kansan north of Cherokee and is there called Iowan till. If seen elsewhere in the Iowan area, it would be interpreted as Iowan, but being here so close to the Wisconsin drift area, there is a possibility that it is Wisconsin drift. Near the northeast corner of section 30, Viola township, there is a roadside exposure of yellowish gray pebbly till that may be Wisconsin drift, but it would fit the Iowan drift better, and it is one-half mile west of the creek valley which forms the west limit of the Wisconsin drift topography.

\section{THE IOWAN BOUNDARY}

The discussion of the Iowan boundary which follows is based primarily on the work of 1913 and is essentially as given in the manuscript of 1915. The tracing of this boundary in the field progressed from north to south and the same order is followed in this description. This order was followed in the field because Leverett had definitely established the division in southwestern Minnesota and because its 
distinctness is strongest there and near the state line, decreasing southward.

In order to become familiar with the characteristics of the Iowan and its boundary in this more definite region, the writer studied the Iowan area from the state line in western Nobles county, Minnesota, north beyond Adrian, having at the time a tracing of the boundary as mapped by Leverett. ${ }^{20}$ The marginal portion of the Iowan region through western Nobles county is a broad, elevated ridge having at places distinctly constructional topography. In general this marginal belt becomes less pronounced from Adrian south to the state line, but all the region seen by the writer in Nobles county is positive, and the boundary is definite.

From the State Line to Little Rock River.-The elevated area that runs southward from Adrian, Minnesota, continues into the northcentral part of Elgin township in the northeast corner of Lyon county. It there becomes indefinite and broken up, on the slopes of Little Rock river valley, and south of the Little Rock it is no longer sufficiently prominent to be mapped as a morainic belt separate from the Iowan drift plain. In fact, the east boundary of this marginal belt north of the Little Rock is quite indefinite, and a marginal belt, separate from the Iowan drift plain, is not shown on Plate I. The course of the boundary southward through west-central Elgin township is shown on Plate I.

To the north and west of the village of Little Rock there are a number of kamelike gravel hills, forming probably the most pronounced development of these features found in the Iowan area south of the state line. In general they rise only 10 to 15 feet above their surroundings, but one in the southeast quarter of section 23 rises 25 feet above its surroundings, so as to be a rather prominent feature, especially from the valley to the south. It is figured in the Lyon county report $\mathrm{t}^{30}$ and is there interpreted as part of the Altamont moraine. In the southwest part of section 27 the topography is plainly constructional, with a number of gravel hills, and a dozen or more low swells with pebbly surfaces appear west of the center of section 34 .

The boundary of the Iowan drift crosses the state line into the northeast part of section 7 of Elgin township and runs southeast through the south-

\footnotetext{
29 Later published by Leverett and Sardeson on Map of Surface Formations of Minnesota, Sheet 3: Minnesota Geol. Survey, Bull, 14

go Iowa Geol. Survey, Vol. X, p. 133, 1900.
} 
west corner of section 8 and diagonally across sections 17 and 21, the boundary lying a short distance to the west of a westward facing slope (Plate I). The railway through section 17 follows along the base of this slope and along the Iowan boundary. In the southeast quarter of section 21 the boundary turns southward and through the east part of section 28 is one-fourth to one-half mile west of a crest along the section line. West of this crest the southwestern part of Elgin township is slightly rolling, sloping gently to the west. East of the crest the region is more rolling and the relief, is in part at least constructional, including the gravel hills of sections 26, 27 and 34. Gravelly swells appear also at several places in the northeast quarter of section 33, just east of the quarter-corner on the south line of section 33, and south of this corner in section 4 . The boundary runs south through the center of section 33 and section 4, Grant township, to Little Rock river valley.

Along Little Rock River and Otter Creek.-Crossing to the east side of Little Rock river valley in section 4, Grant township, the boundary follows the valley southward across Grant township and southwestward across the northwest corner of Dale and the northeast part of Wheeler townships to the entrance of Otter creek in section 21 (Plate I). In the southern part of this course in Dale and Wheeler townships the boundary bends, westward $51 / 2$ miles in making $31 / 2$ miles to the south.

In this course along Little Rock river a slight difference in the topography is noted in passing from one side of the valley to the other. To the west the region has more open valleys with long smooth slopes and definite divides, affording long views either along or across the valleys. To the east the larger topographic features still seem to be due to pre-Iowan erosion, and the area is well drained, but the valley slopes are not so smooth, and the valleys are somewhat obstructed, giving to the whole region a more billowy surface. The difference is not such that one can identify each quarter section as belonging to one or the other division, but larger areas must be considered. There is nothing along this margin to suggest the marginal morainic belt that exists farther north, and in fact much of the central part of Grant township has very few constructional features in its topography. More characteristic Iowan drift topography is found farther east along the county line and in West Holman township of Osceola county.

Eastern and central Grant township drains by westward flowing streams to the Little Rock. The relief is 30 to 50 feet and the surface is moderately 
rolling. Although there are quarter sections or even whole sections that are indecisive, the whole of the township east of the river has been included in the Iowan. Some of the evidence for bringing the boundary westward to the valley is as follows: The northwest part of section 9 has an undulating surface, with poorly drained depressions, sandy material at places, and bowlders on the slopes of the valley. The valley slope on the west line of section 9 showed gravel overlain by a mixture of till and gravel, the till being of the type that is considered Iowan. The southwest quarter of section 9 has an undulating surface on the valley slope and the southwest part of section 16 shows the same features to a less degree. At the quarter-section corner on the south of section 20 , at the very edge of the valley is a gravel mound cut by the road grading, and several other pebbly swells are found in the field just north of the road. There is an undulating surface just southeast of the center of section 20 . The soil is in places sandy, as on the east of section 29 , the north of section 20 and elsewhere in Grant township, and pebbles appear on many low swells or are exposed in shallow road cuts. All these are characteristic features of the Iowan drift but not of the Kansan of this region. Besides these more specific cases along the valley margin there is, as noted above, the general undulating surface of all the region to the east of the river.

Along the east side of the valley through Wheeler township there is very conclusive evidence that the Iowan region extends to the valley's edge. A billowy surface is found in many places, sandy material is present in the soil, and a few bowlders lie on the surface. In the north half of the southeast quarter of section 11, south of George, the surface is billowy, and similar topography appears also in section 23 , the east part of section 21 , section 27 , the north part of section 35 and elsewhere. Sandy places exist along the roads on the west of sections 14 and 23 and on the north of section 27 , and pebbly surfaces were seen in the northeast quarter of section 27, the southwest quarter of section 22 , the southeast quarter of section 21 and the northeast quarter of section 35. Some of these gravelly places are on low swells that are evidently gravel hills. Bowlders lie along the fence rows at several places, as near the southwest and southeast corners of section 22 and around the northwest corner of section 36 . The evidence therefore seems conclusive enough that the ice pushed out to the valleys across Wheeler township, even into section 21 .

Eastern Wheeler township for several miles east from the valleys is much like the central part of Grant township; moderately rolling, well drained, and with only the scattered bits of evidence noted above that the Iowan ice covered it. To the east the topography becomes less rolling and in Dale township a typical development of the slightly rolling Iowan 
drift plain with a relief of 10 to 20 feet is found. In no place is there a topography of terminal moraine aspect.

In section 21 of Wheeler township, Little Rock river is joined by Otter creek, which enters from the southeast. At the union of these valleys the Iowan boundary changes its direction to southeast and follows up the northeast side of Otter creek valley across southern Wheeler township and across the northeast corner of Sheridan township, Sioux county, a distance of about five miles (Plate I). Here, in section 7 of Grant township, southwest of Matlock, Otter creek changes its direction and heads off to the northeast, but the Iowan drift boundary crosses the valley and continues its course southeast.

Gravel deposits appear along Little Rock river and Otter creek valleys where they flow along the drift margin and to a less extent along Otter creek and Rat creek within the Iowan drift area. There are low benches at many places along Little Rock river, remnants of the valley filling. The general width of the flat of this valley is about half a mile, most of which is below the bench level.

After the change of direction at the mouth of Otter creek the Iowan drift boundary holds a regular course east of south across several counties (Plate I), a course parallel to that across southwestern Minnesota. Between these two parts the boundary curves westward in eastern Lyon county, extending into the angle between Little Rock river and Otter creek. In Minnesota the ice which reached the Iowan drift boundary had to cross the high area known as the Coteau des Prairies. This high area breaks down in southern Nobles county, and south of this region the ice moving obliquely toward the boundary had an easier course and was able to push farther to the west. The ice that crossed the line of the Coteau des Prairies in southern Nobles and northern Osceola counties probably reached the boundary in southern Lyon county, causing the westward bend described above. The ice found in western Osceola county a rather level upland and in Dale township a very level plain, so that it was able to push out to the valleys of Wheeler township.

Alternative Boundary in Lyon County.-West of the boundary traced through Elgin township and extending westward for about two miles into Midland township and covering the contiguous corners of Liberal and Grant townships to the south, is an indefinite area included in Wilder's "Wisconsin, Partially Stratified" unit (figure 3). It 
has an even surface in part, sloping gently westward, and there is considerable gravel along the stream courses. The topography is, in general, more like Kansan than Iowan but somewhat filled up by gravel along the stream courses. Till exposures were seen on the west lines of sections 20 and 17, Elgin township, but they are of the questionable type, neither distinctive Kansan nor Iowan. Some low gravel hills on the north of section 36, Midland township, and gravel deposits around the northwest corner of the same section suggest Iowan. The west half of Midland township has definite Kansan topography and till. It seems better to leave this indefinite area of western Elgin and eastern Midland townships in the Kansan region, but modified by Iowan outwash.

Northwest of George in sections 34 and 27, Liberal township, there is a north-south ridge and in section 26 a hill that may be constructional, but they are not positive. A similar northeast-southwest ridge exists in section 19, Grant township. These features suggest that the Iowan ice sheet crossed Little Rock river valley in Grant township and had its edge in eastern Liberal township. A suggested boundary that would include these possibly constructional ridges northwest and northeast of George, as well as some of the indefinite area of western Elgin township, is shown on Plate I. It is three to four miles west of the boundary traced above, in southwestern Elgin and Grant townships. It passes along the west side of the ridge northwest of George and thence south to join with the boundary traced above, at the mouth of Otter creek.

This alternative boundary would bring within the Iowan the possibly constructional ridges near George but has little else to support it farther north. It would not bring into the Iowan the whole of the "Wisconsin Partially Stratified" unit of Wilder. To do so would require a north-south boundary through the centers of Liberal and Midland townships. The boundary traced in the foregoing section, which follows the Little Rock river valley, uses, more consistently, those characteristics upon which the boundary is based to the north and south.

From Otter Creek to Floyd River.-After crossing Otter creek southwest of Matlock, the boundary runs southeast across Grant township and reaches Floyd river in the northeast corner of Lynn township, southwest of Sheldon (Plate I). For most of this distance the boun- 
dary is well defined, being marked either by a southwestward facing slope or by a ridge that overlooks the region in either direction.

To the northeast of the boundary the central part of Grant township has a characteristic Iowan drift topography of slight relief and undulating surface, with locally, as in the east half of section 16, a tendency toward marshiness. To the northwest along Otter creek and to the southeast along Floyd river the relief is greater and the Iowan drift characters are not so well defined.

Outside the boundary the Kansan drift topography is characterized by broad, open valleys with long, smooth slopes. Sheridan township, southwest of Otter creek, has a moderately rolling erosional topography near the valley, but to the southwest this passes into an upland of slight relief which covers the central part of the township. This upland has less relief than most of the areas of Iowan drift, but here all the valleys are broad with smooth slopes and head in a level plain.

The course of the boundary is not well defined through section 7; Grant township, just south of Otter creek, but in the northwest quarter of section 17 a ridge or southwestward facing slope begins and continues southeast through the southeast part of section 17 , the southwest corner of section 16 and the northwest quarter of section 21 and dies out in the south part of section 21. A similar slope appears again in the northeast quarter of section 28 and continues either as a front or as a ridge diagonally through sections 27 and 35, across the northeast quarter of section 2 and the west part of section 1 of Lynn township to Floyd river (Plate I). In the southwest quarter of section 16 the outer slope of the ridge rises 30 feet in a short distance, the crest is about 200 yards wide, and a slope leads down to the Iowan plain to the east. Through section 27 the front has an altitude of 15 to 20 feet.

Opportunities for observing the drift are few along this part of the boundary. In the material thrown from a well on the south line of section 6 , Grant township, two tills were apparently represented, and in the southwest quarter of section 16 ash-colored sandy till with pebbles, apparently Iowan, continues to the surface of the ridge which here forms the boundary. The sandy material found at many places along the boundary farther north does not appear south of Otter creek, but pebbles were found along the ridge in the southwest part of section 16 . The boundary here is largely a topographic boundary, but it is sufficiently well defined, being marked by the contrast of the topographies to the northeast and to the southwest and for most of the distance by a ridge or a low southwestward facing slope. 
From Floyd River to Mill Creck.-Crossing Floyd river southwest of Sheldon the boundary continues southeast across southern Carroll, northeastern Baker, southwestern Dale and northwestern Union townships, O'Brien county, to Mill creek southwest of Paullina (Plate I). On the county line south of Sheldon there is a low ridge along the border, and its crest overlooks, to the southwest a thoroughly dissected Kansan drift plain, and to the northeast a slightly rolling, billowy Iowan drift plain in which the location of the drainage courses is not distinct. The contrast of the views to the southwest and northeast from this ridge is one of the best along the Iowan drift boundary. In the southwest corner of Dale township the boundary comes into the valley of Mud creek and follows down this valley to Mill creek.

The Iowan drift boundary crosses Floyd river in the northwest quarter of section 12, Lynn township, Sioux county. It thence runs southeast through the southwest quarter of section 12 and the northeast quarter of section 13 along the base of the outer slope of the low ridge noted above. Continuing into Carroll township of O'Brien county, it passes through section 18, the northeast part of section 19, and the south part of section 20 , marked by a low swell with a low front to the southwest. To the northeast, sections 18,17, 20 and 21 have a slightly rolling, billowy Iowan surface, while to the southwest the valleys are broad and the slopes smooth.

The boundary through southern Carroll and northeastern Baker townships is less definite. Low northwest-southeast ridges in the northwest quarter of section 27 and the southwest quarter of section 35, Carroll township, and the southwest quarter of section 1, Baker township, suggest a boundary along this course, but the topography and an exposure on the east line of the northeast quarter of section 33, Carroll township, indicate that the ice really advanced one-half to one mile southwest of the low ridges. The boundary is mapped as running southeast through the northeast part of section 29, the southwest corner of section 28 , the northeast part of section 33, and the southwest corner of section 34, Carroll township, and continuing through the northeast quarter of section 3 , the southwest quarter of section 2 , the northeast quarter of section 11 , the southwest quarter of section 12 and the east part of section 13, Baker township. In these sections there is not even a low front at the Iowan drift margin, and the Kansan drift region just outside the boundary is only slightly rolling and in part is even more level than the Iowan, where the latter has its usual development.

An interesting shallow roadside exposure existed about 80 rods south of the northeast corner of section 33, Carroll township, in 1927. 
The relations of the several parts exposed are shown in the sketch forming figure 10. A low mound cut across by road grading consists

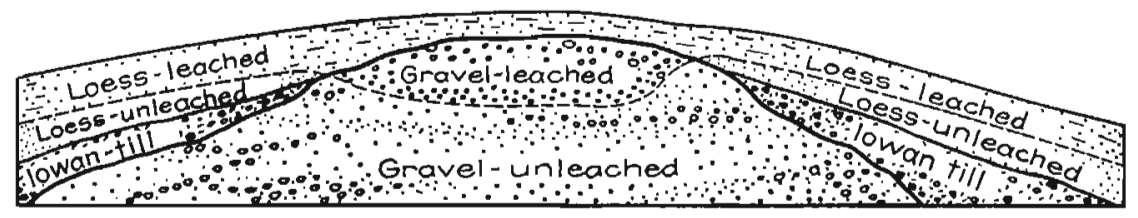

FrG. 10.-Sketch of a roadside exposure about 80 rods south of the northeast corner of section 33, Carroll township, O'Brien county, showing the relations of Iowan till on the flanks of a low gravel mound to the overlying loess and to the gravel below.

largely of gravel. On the flanks Iowan till overlies the gravel, wedging out up the slope before reaching the top. The mound is covered with a coat of loess about three feet thick on the lower slopes but thinning toward the top of the mound, as is usual, to less than two feet and becoming somewhat sandy. The depth of leaching in the loess is about two feet which, over the crest of the hill, is sufficient to go through the loess into the gravels. The gravel beneath the till and beneath the unleached loess is unleached, but over the center of the hill where the loess is entirely leached the gravel below is leached to a depth of four feet below the surface. The relations between the leached and unleached gravels and between the other units show clearly that leaching has progressed much more rapidly in the gravel than in the loess or other more compact materials. The till and gravel are of the type more definitely recognized as Iowan and show that the ice pushed this far southwest. About half a mile farther south on the west of the southwest quarter of section 34 the roadside cut showed beneath the soil one foot of fresh gravel over brown till, with many calcareous concretions, which should be Kansan. The boundary is drawn between these two exposures.

A low ridge, barely recognizable on the east line of Baker township, continues southeast into Dale township through sections 18 and 19, and increasing in size southward, becomes a ridge of some prominence in the east part of section 30, the southwest quarter of section 29 and the central part of section 32. The topography along this ridge and to the east in sections 18 and 19 is plainly constructional. The Iowan drift boundary lies along the west base of this ridge across the southwest quarter of section 18, the west-central part of section 19, the east-central part of section 30 and along the line between sections 31 and 32 . Near the southwest corner of section 32 a creek bank showed three feet of loess, leached 
nearly to the base, resting on three feet of fresh gravels of the Iowan type. In the northeast quarter of section 31, Mud creek, which has had a northeasterly course for four miles, is within one mile of Mill creek, from which it is separated by the ridge 40 to 50 feet above it which marks the Iowan drift boundary. The creek here turns sharply to the south and flows $3 \mathrm{I} / 2$ miles before joining Mill creek.

In northern Union township a billowy glacial topography appears on the elevated area separating Mud creek from Mill creek, and the boundary follows the east slope of Mud creek valley through sections 5, 8 and 17 to Mill creek valley. Shoulders of sand and gravel begin to appear in Mud creek valley in section 5 and become more numerous southward until in section 17 an almost continuous bench borders either side of the valley at an altitude of 20 to 25 feet above the stream. The road on the east line of section 17 is on this bench, and the road cuts show many exposures of dirty sand and gravel. Bowlders were seen in the northeast quarter of section 17, at the southwest corner of section 9 and along the road south of the center of section 9 .

Along Mill Creek in Southern O'Brien and Northern Cherokee Counties.--In southern O'Brien and northern Cherokee counties the region to the east of Mill creek shows in most places the characteristics of the lowan drift plain, while the region to the west shows those of the Kansan. The boundary, therefore, for this distance of 15 to 20 miles from the mouth of Mud creek, southwest of Paullina, southeast to Little Sioux river is placed along the east edge of Mill creek valley (Plate I). If this were the margin of a drift sheet of more pronounced characteristics the boundary probably would be found to run in general along the east side of the valley but not always exactly at its edge; but with a drift sheet of this type there is nothing definite enough about the boundary to justify minor irregularities, and it has seemed better to draw a more generalized boundary, following the valley edge. In several places the Iowan topography comes up to the edge of the valley and it generally can be recognized within one to two miles of the valley, but it would not be possible to prove that the Iowan ice reached the valley at all places.

West of Mill creek the well dissected Kansan topography with broad, open valleys and rounded slopes is found. Farther back to the southwest the relief decreases and the topography passes into the more level upland type of Kansan plain.

A prominent characteristic of Mill creek valley is the presence of 
great gravel deposits along it. These begin as filled-in areas west of Primghar, where the creek has cut little more than a channel into the aggraded plain. Southward the cutting below this plain increases and shoulder-like benches appear along the valley sides. At the county line the benches are 50 feet above the creek, and near the mouth of Mill creek they stand 90 to 100 feet above the stream (figure 23). The gravels of these benches are discussed further on pages 156 to 158 . Great quantities of gravel have been removed in the excavation of the immediate valley of the present stream, and when these are taken into consideration along with that which still remains in the benches, we get some conception of the enormous quantity of gravel that was deposited along Mill creek valley by the waters that flowed out from the Iowan ice front.

Mill creek valley was a stream valley in pre-Iowan times, for it has a long slope leading down from the west. In two places, however, the creek may have been diverted locally. One of these is in southern O'Brien county south of Paullina, from the mouth of Mud creek to the mouth of Nelson creek; and the other is in Cherokee township, from the north part of section 10 to the mouth of Mill creek.

Just opposite the mouth of Mud creek, southwest of Paullina, a high ridgelike area begins and continues, with several minor offshoots, southeast through sections $21,28,27,34$ and 35 , terminating just south of the county line. The area is almost surrounded by valleys, has a relief of 30 to 50 feet, and drains outward in all directions. Its characters are not positive and it may be questioned whether it should be included within the Iowan. If it is not included, the boundary should pass from the mouth of Mud creek east along Mill creek across section 16 and southeast along a low course diagonally across section 22 to Nelson creek valley and thence down this valley through sections 26 and 36 to Mill creek valley.

The crests of this high area stand at an altitude of 85 to 100 feet above Mill creek, which bounds it on the north, west and south, and above Nelson and Willow creeks on the east. Because of this greater relief the billowy topography characteristic of the Iowan drift is not present and yet the drainage courses are not the broad, open valleys characteristic of the Kansan. At several places erosion. has just started to notch the slopes, and sections 21, 28 and 27 show faint indications of Iowan drift. After considering in the field all the possibilities, it seemed best to include this elevated area of south-central Union township in the Iowan and place the boundary along the east slope of Mill creek valley.

South of the mouth of Nelson creek there is fairly conclusive evidence 
that the ice pushed up to the east edge of Mill creek valley, on south to its union with the Little Sioux. Central Cedar township has typical Iowan topography and in most places this continues to within one to two miles of the valley and locally up to its very edge. Along the township line on the west of section 18 an area only three-fourths of a mile from the valley is slightly rolling over an extent of 40 acres; and there are similar areas near the valley in the central part of section 19, in the southwest quarter of section 28 , in the north half of section 33 , and in the central part of section 3 and the southwest quarter of section 11 of Cherokee township.

A cut on the east side of a ravine on the north line of the northwest quarter of section 20, Cedar township, shows lighter colored till, probably Iowan, over a yellow-brown till that is certainly Kansan. Other exposures of till interpreted as Iowan along or near this boundary are noted on pages 56 to 58 and 84 to 89 of this report.

From the Mouth of Mill Creek Southeast to Maple River.-At the mouth of Mill creek the Iowan boundary comes to the valley of the Little Sioux, and from here southward past Cherokee and southeast to Maple river the location of the boundary is quite uncertain. The Iowan ice pushed up to the edge of the Little Sioux valley, southward to a point opposite Cherokee, for the billowy Iowan surface is well developed in sections 13 and 24, Cherokee township, and in the southwest quarter of section 25 at the very edge of the valley. The edge of the ice probably was within the Little Sioux valley southward across sections 23 and 26 to Cherokee, for deposits exposed along Spruce street in the north part of the town appear to be Iowan drift (page 71).

The region east and southeast of Cherokee in southwestern Afton and northwestern Pitcher townships has a billowy topography of the Iowan type, while the region south of Cherokee in northeastern Pilot township has a well dissected erosional topography. The boundary between the two regions is not very definite but a comparison of the topographies usually serves to locate it within a mile or less. The position of the boundary as mapped on the basis of topography is shown on Plate I.

The Iowan drift boundary as here mapped leaves the Little Sioux valley east of Cherokee, where the valley swings to the southwest, and runs across section 36, Cherokee township, the northeast quarter of section 1 of Pilot township, and the southwest quarter of section 6, Pitcher township: On the north line of section 7 , Pitcher township, the front is marked by a rise of 20 to 25 feet where the boundary crosses from the Little Sioux to 
the Maple river drainage. The boundary thence passes through the westcentral part of section 7 and, with less definite characters, through the east part of sections 18 and 19 , to the Maple river valley in the southwest quarter of section 20 (Plate I).

Alternative Boundary just South of Cherokee.-The tracing of the Iowan boundary from the mouth of Mill creek to Maple river is based upon the same criteria as the boundary to the north and south. There are, however, certain deposits at and south of Cherokee that suggest a different boundary farther west than the one traced above. Because these deposits bear primarily upon the location of the Iowan boundary, they will be discussed here as a basis for the statements concerning an alternative boundary.

A cut on Spruce street, just east of Second street, in the north part of Cherokee, within the area of the higher bench level, showed a great diversity of material including gravel, sand, bowlders and till layers. There are many alternations of the material horizontally and vertically. The gravel is coarse, dirty, and contains many large bowlders. Clayballs are abundant, and in some horizons there is only a little gravel as matrix between the large clay masses. One bed appeared to be till, but when it was dug into, the material separated into rounded masses of till which are packed together without matrix. Also there are lenses or layers of Iowan till, too large to have been floated in, which must have been deposited directly by the ice. The upper seven or eight feet of the cut showed the more common valley gravels overlain by loess. This exposure, which is in the northwest quarter of the southeast quarter of section 27, could be accounted for as Iowan by the very probable interpretation that the part of the Iowan ice sheet within the Little Sioux valley pushed a little farther southward than did the ice on the broken edge of the upland just to the east. This outcrop does not require an alternative boundary.

One hundred yards northwest of the Illinois Central Railway roundhouse, in the southwest part of Cherokee, an abandoned pit on the valley slope showed about 10 feet of yellow sand and gravel overlain by about 25 feet of till, which is apparently Kansan. A slope, apparently of till, rises ahout 20 feet higher to a high bench of the Little Sioux valley, underlain by at least a few feet of gravel. The till is chiefly blue-gray pebbly clay as fresh, oxidizing to yellow clay with iron 
staining along the joints. It contains many calcareous concretions and has much sand and gravel mixed through it.

The possibility of this being an exposure of Iowan till over sand and gravel, all kaid down in the Little Sioux valley by a slightly greater extension of the prong of Iowan ice within the Little Sioux valley suggested above, was fully considered in the field. The till, however, is not the type commonly called Iowan and its thickness is greater than any known thickness of undoubted Iowan.

The base of the sand and gravel was not exposed, but the exposure is but slightly above the bench upon which Cherokee stands and which is underlain by Nebraskan till. The till above the sand and gravel is, therefore, at the horizon of the Kansan of this region, with which it agrees in its characteristics. Such an interpretation would place the sand and gravel at the Aftonian horizon, but they are calcareous and not notably. altered at the contact with the till above. They are believed to be outwash in front of the advancing Kansan ice sheet, which then deposited a thick till horizon over the sand and gravel. The gravel is more highly oxidized than the usual valley gravels and the limestone pebbles are more or less altered. In a pebble count of 100 pebbles, 45 were limestone, but of these only three were classified as fresh compact limestone. The till and the underlying sand and gravel are interpreted as Kansan.

The east-central part of Pilot township south of Cherokee is sharply dissected by several small creeks that head in the east part of the township. Along these creek valleys are a number of exposures of sand and gravel, silt, till, etc. The north one of these creek valleys in sections 10,11 and 1 heads in the Iowan region as the boundary is traced above, but its branches from the south and the other ravines farther south do not reach the Iowan area as mapped. This is a questionable area lving just outside the Iowan boundary as traced above, or it may be included in the Iowan region by placing the boundary farther southwest. The silts are in general of the type found in valleys at various places in northwestern and western Iowa and assigned to the Loveland (page 49). With these silts, in the valleys of northeastern Pilot township, an unusual amount of gravel is associated and interbedded, and this gravel is, in general, like that of the Iowan region.

The most northern one of these creeks heads in the southwest corner of Afton township and flows southwest diagonally across section 1 , the north 
part of section 11, and the central part of section 10, Pilot township. Its head is within the Iowan boundary as traced above, across the northeast part of section 1, and the usual valley gravels are present along the valley in section 1, overlain by the loesslike clay. Farther down the valley some exposures show a considerable thickness of clean, fine gravel and quartz sand, as in the railway cut in the northeast quarter of section 11, and above a prominent spring zone on the south side of the valley near the west line of section 11. In other exposures silts and silty sands predominate.

The higher terrace of the Little Sioux valley continues into the lower end of the valley in section 10 and is represented by gravel benches up the valley almost to the township corner. Similar benches are also present along tributary branches from the southeast in section 11 . In its lower course this creek valley is down in the horizon of the Nebraskan till and in section 10, where the creek crosses the terrace area of the Little Sioux, there are exposures of this till 30 to 50 feet above the creek bed. The gravels of the Little Sioux bench here rest on the Nebraskan till.

In the southeast corner of section 2 at the union of a ravine from the north with this creek valley the following section was exposed:

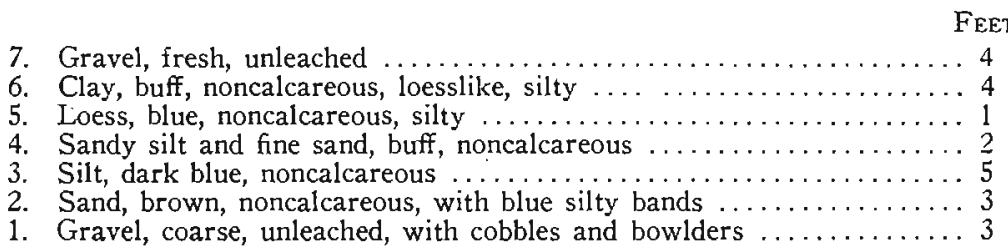

The fresh calcareous gravel at the top (No. 7) is interpreted as Iowan. Zones 6 to 2 below form a unit of calcareous silts and silty sands 15 feet thick and are interpreted as Loveland. It seems more probable that they accumulated as noncalcareous sediments derived from leached surface materials, rather than that they have been leached in place, especially since the next horizon below (No. 1) is a calcareous gravel but contains no calcareous concretions. Number 1 is also interpreted as Loveland. Its base was not exposed, but it probably rests upon till as does the similar horizon (No. 2) of the succeeding section.

Farther up this creek near a railway bridge in the southwest corner of section 1, the bank shows about 12 feet of the Loveland horizon consisting of blue, silty material above and brownish blue, humus-bearing material below, with some snail shells.

An exposure in the west bank of the creek south of the east end of a railway cut in the northeast quarter of the northeast quarter of section 11 showed the following: 
8. Clay, brown, weathered, including soil above $\ldots \ldots \ldots \ldots \ldots \ldots \ldots 21 / 2$

7. Silt, blue-gray, and brown, sandy silt $\ldots \ldots \ldots \ldots \ldots \ldots \ldots \ldots \ldots, 2$

6. Silt, blue-gray, with some sandy silt $\ldots \ldots \ldots \ldots \ldots \ldots \ldots \ldots \ldots \ldots \ldots \ldots \ldots \ldots \ldots \ldots \ldots \ldots$

5. Sand, yellowish, fine-grained, with a few bands of dark blue-gray silt 2

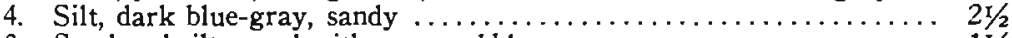

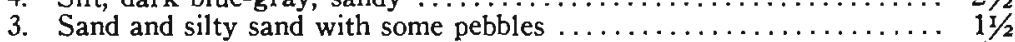

2. Gravel, very coarse, with cobbles and bowlders $\ldots \ldots \ldots \ldots \ldots \ldots, 5$

1. Till, light brown, gummy. Nebraskan ...................... 13

The material is quite variable and a section a short distance laterally might be quite different in details. Zones 4 to 8 are the type of material that characterizes the Loveland and zones 2 and 3 below must go with the Loveland also. The whole makes a thickness of $18 \mathrm{1} / 2$ feet. The silt zones ( 4 to 8 ) are noncalcareous, while the gravel zone (No. 2) contains limestone pebbles.

In the creek bank just south of a railway bridge in the northwest corner of the southwest "quarter of the northeast quarter of section 11, Pilot township, the following section was seen:

3. Clay, dark gray to dark drab, noncalcareous, compact, silty $\ldots \ldots \ldots \ldots . . . \ldots$

2. Sand and silty sand, noncalcareous $\ldots \ldots \ldots \ldots \ldots \ldots \ldots \ldots \ldots$

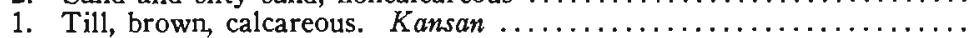

A few rods farther southeast is a much higher bank, but it was so badly slumped that the section could not be made out. It is Kansan till at the base, overlain at places by one to two feet of coarse ferruginous gravel and then by 12 to 15 feet of noncalcareous brown loesslike clay and silty sand, which apparently is Loveland but all badly slumped and poorly exposed. A grass-covered steep slope rises 15 to 20 feet higher.

In the bank of a tributary of this creek valley from the southeast, just south of the north line of section 14, the following section was exposed:

5. Surface loam, dark yellow $\ldots \ldots \ldots \ldots \ldots \ldots \ldots \ldots \ldots \ldots \ldots \ldots \ldots \ldots$

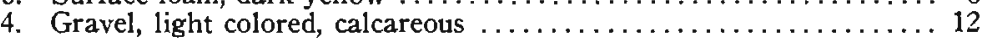

3. Silts, brownish yellow, with a strongly ferruginous layer at the top $4 \mathrm{r} / 2$

2. Bowlder zone with a pebble matrix $\ldots \ldots \ldots \ldots \ldots \ldots \ldots \ldots \ldots \ldots \ldots \ldots \ldots$

1. Till. Nebraskan .............................. 10

Zone 5 is probably surface wash, zone 4 is probably Iowan gravel. Zone 3 is Loveland and the strongly ferruginous layer at its top may represent an old sóil zone, or it may be simply a concentration of irony material at the top of a relatively impervious zone.

Near the east line of section 10 in the south bank of the creek is an exposure which was studied in 1910 and again in 1927. At the later date the exposure was as shown in figure 11 but was too irregular for a section. The till at the base is Kansan. The horizontally bedded gravel at the top is Iowan. The irregular unit of gravel, sand, silt and till between cannot be 
definitely placed. The irregular mass of till at the top of this unit is somewhat lighter in color than the usual Kansan, but this is commonly true of the till associated with gravel.

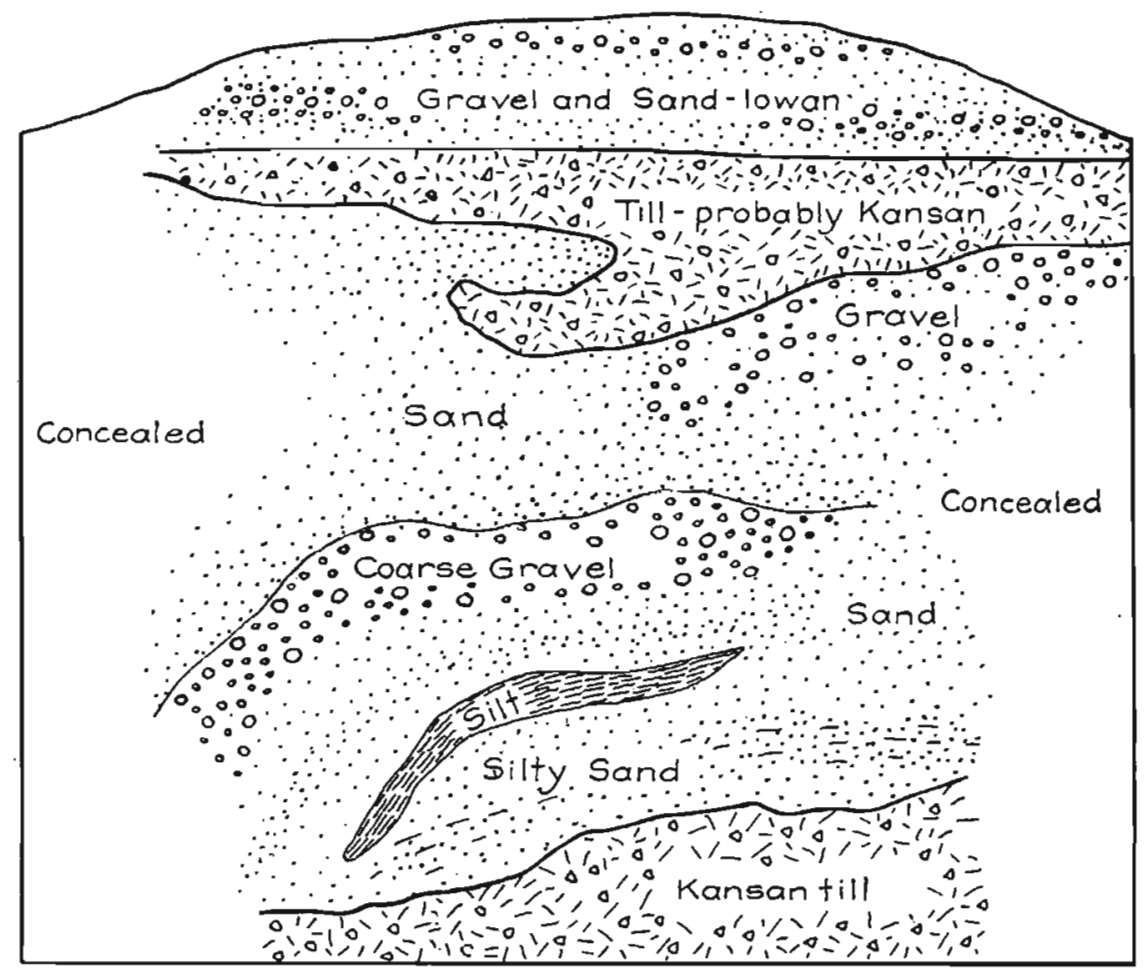

Fig. 11.-Sketch of an exposure in the creek bank near the east line of section 10, Pilot township, Cherokee county, showing a greatly contorted and mixed sand and gravel mass resting on Kansan till and with probable Kansan till above. The horizontally bedded gravel and sand at the top is apparently Iowan.

The irregular character of this unit suggests that a deposit of sand and gravel was plowed by an ice sheet which distorted it and introduced the till at the top. If the upper fill is Iowan, then the Iowan ice sheet extended to this place, overrode and distorted the gravel which had probably been deposited just in front of the ice sheet, and introduced the till. If the upper till is interpreted as Kansan, then the Kansan ice sheet plowed up a deposit of gravel which had possibly been formed just in front of the ice sheet and incorporated a mass of it in the Kansan till; or a deposit of gravel within a moulin up in the Kansan ice sheet might have furnished the gravel. If all the till is Kansan, then this mass belongs to the class of included gravel masses to be discussed on pages 111 to 115 .

The elevations of the various exposures of unquestioned Nebraskan and 
Kansan tills along these creek valleys show that the Kansan drift sheet was laid down on a surface of Nebraskan till which had a relief of at least 50 feet. If the upper till is Iowan, then it was deposited down in a valley 75 to 100 feet deep, cut through the Kansan drift into the horizon of the Nebraskan drift, as shown by the Kansan and Nebraskan exposures on the upper slopes of this valley, one-fourth mile to the north. The writer interprets all the till of this exposure as Kansan and the irregular gravel mass below the upper till as Kansan gravel included in Kansan till.

The next creek valley to the south in section 23 and the northeast part of section 22 has similar deposits. The south slope of this valley in the northeast part of section 22 showed the following section. some cobbles up to 8 inches in diameter ...................... 17

4. Sand, yellow, calcareous, medium-grained, with coarser layers in upper part and grading downward to fine-grained sand with silty layers 15

3. Silt, sandy silt and fine sand in alternating layers, calcareous, blue to brown, compact .................................... 17 Some of the silt layers contain snail shells.

2. Sand, coarse, and fine-grained gravel with a layer of bowlders at the

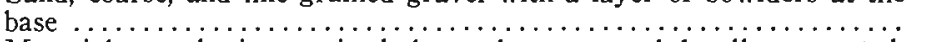
Material greatly iron-stained, but calcareous and locally cemented. Copious springs issue at the base of this zone.

1. Till, tough, greenish blue, with a very few pebbles. Nebraskan .... 9

The principal silt division (No. 3) is certainly the same as that called Loveland in the valley to the north, but here it is calcareous and also appears to grade through sandy silt and fine sand (No. 4) to the gravel horizon at the top as if the whole belonged to one unit.

About 150 yards southeast of the large exposure just noted, the south bank of the ravine showed the following:

FEeT

3. Silt, calcareous, and sandy silt, in alternating layers $\ldots \ldots \ldots \ldots \ldots 5$

2. Loesslike clay, blue, calcareous, with many snail shells $\ldots \ldots \ldots \ldots \ldots 5$

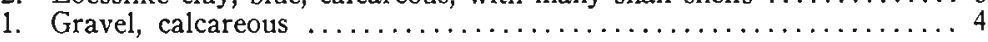

Farther up this creek valley near the quarter-section line in the north part of section 23 there are several exposures of silts and gravels too badly. slumped to yield sections.

In the southeast quarter of the northeast quarter of section 23, about 100 yards west of the road, the north bank of this valley showed the following:

FEeT

6. Loesslike clay, buff to brown, leached, with a few thin seams of

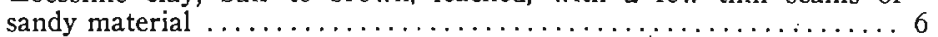

5. Silts, calcareous, sandy, with a few pebbles ................... 3

4. Silts, gray, calcareous, sandy, with a few fossils $\ldots \ldots \ldots \ldots \ldots \ldots \ldots \ldots$

3. Gravel and sand, mottled dark brown, calcareous, with some black

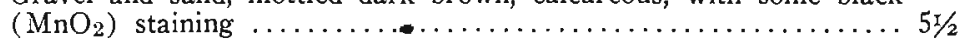

2. Gravel, calcareous, rusty, coarse, with black $\left(\mathrm{MnO}_{2}\right)$ staining ..... 3

1. Silts, dark gray, calcareous, sandy, with carbonaceous material ..... 2 
Zone 1 comes down to the base of the exposure at the center, but to the east and the west the Nebraskan till appears from below and rises to a height of about 10 feet in the bank, with the several lower zones of the above section abutting laterally against the till. On the east there is also Kansan above the Nebraskan, but its lateral contact with the silts is concealed. The horizontally bedded silts were evidently laid down in a depression cut through the Kansan into the Nebraskan till.

The interpretation of the silts, tills and gravels of Pilot township has a bearing on the mapping of the Iowan boundary. As noted above the Iowan boundary as traced in the foregoing section would not permit Iowan drainage to enter all of these valleys. A somewhat greater extension of the Iowan region into the east edge of Pilot township would permit Iowan drainage to enter all of these valleys; an extension of the Iowan region to the Little Sioux, southward from Cherokee to the center of Pilot township, would include all the region discussed under this heading. These two alternative boundaries are shown on Plate I.

The topography of northeastern Pilot township shows none of the characteristics of the Iowan drift region. The two exposures of till suggesting Iowan, that near the round-house in southwestern Cherokee (page 71) and that near the east line of section 10, Pilot township (page 74), can both be better interpreted as Kansan. There is, therefore, no basis for an extension of the Iowan region to the Little Sioux valley in central Pilot township.

The silts and silty sands of Pilot township are not. a characteristic feature of the Iowan region, but the associated gravels are like those of the Iowan region. However, both types of deposits exist out on the Kansan region beyond the greatest possible extension of the Iowan region. For example, in a small valley tributary to the Little Sioux in the central part of section 6, Silver township, five miles southwest of the exposure in section 22 described above, there is an exposure of about 15 feet of blue-gray silty material with interbedded layers of sand and with some fresh gravel overlying. It is only in the notably greater development of the silts and sands that Pilot township stands out.

Most of the sections described above under this heading show a horizon of fresh gravel at the top, and it is probable that the lowan ice sheet did cover the divide along the east line of Pilot township south- 
ward to section 24 and furnished the drainage which brought in these gravels. These gravels are not well set off from the silts below and in one section (page 76) they appear to grade into each other. It is probable, therefore, that the silts represent only a small part of the entire Loveland, namely that part just preceding the Iowan ice age. In fact, it is possible that the silts of Pilot township were thrown down in the slack waters of the tributary valleys of the Little Sioux, which were ponded by the aggradation of the floor of the major valley by the Iowan outwash gravels which built the high terrace level of the Little Sioux valley. By this interpretation they would be essentially Iowan in age.

Along Maple River Valley.-Southward from southwestern Pitcher township the Maple river valley forms the approximate boundary of the Iowan drift southward for about 12 miles to Galva in northeastern Ida county (Plate I). This again is a generalized boundary as was true along Mill creek valley, and it would not be possible to show that the ice came down to the valley everywhere along this course. Several miles back from the boundary in eastern Pitcher and Diamond townships, and on to the east in Buena Vista county, the Iowan topography is well developed.

A number of kamelike gravel hills are found east of Maple river in southern Pitcher and in Diamond townships, and these aid in giving a constructional appearance to the topography. They have their best development in sections 28 and 33 of Pitcher township and in sections 4 and 35 of Diamond township (page 97).

Besides the gravel hills indicative of Iowan age there are examples of the billowy Iowan topography near the Maple river valley in the northwest quarter of section 21 and the southwest quarter of section 33, Pitcher township, and in section 4, the west part of section 16, the east part of section 28 and the north part of section 34, Diamond township. Pebbly swells appear also on the north line of section 16 and in the northeast quarter of section 28 .

In Galva township of Ida county the relief for two to three miles back from Maple river is 50 to 75 feet, and in this greater relief the Iowan topography does not have its typical development. However, in the northeast quarter of section 15 and the southeast quarter of section 10 there is a group of gravel hills, one of which on the section line has an exposure showing a ferruginous, dirty gravel with clay-balls; in the northeast quarter of section 24 there are a dozen or more low swells that show pebbles; 
pebbly surfaces were seen in the northwest quarter of section 12 , the north half of section 23 and the northwest quarter of section 25 ; and slightly billowy surfaces suggestive of Iowan drift appear at several places. On the whole, the evidence seems sufficient to justify placing the boundary along the Maple river valley southward to the mouth of a small creek that enters just west of Galva.

Farther eastward the northwestern part of Sac county shows good Iowan drift topography between Early and Schaller and west almost to the county line, where the less typical Iowan noted above begins.

At the northwest corner of section 26, Galva township, just southwest of the village of Galva, a road cut beneath the railway showed, in 1927, leached buff loess 10 . feet thick, overlying five feet of sand and finegrained gravel which is in part leached to a depth of one foot. The exposure is just at the boundary of the Iowan drift area, as mapped, and the sand and gravel look like Iowan material, but the thickness of the overlying loess and the depth of leaching is unusual.

West of Maple river valley in southeastern Cherokee and northern Ida counties an erosional topography on Kansan drift is found. On the slope of the valley it is not very different from the Iowan to the east, but two to three miles to the west the typical Kansan topography appears.

Maple river is bordered by a valley flat one-fourth to one-half mile in width which is in part at least underlain with gravel, but only at a few places do gravel benches appear. The small creek valley of section 23 at Galva carries a gravel deposit and there are low benches on either side of this valley. A pit has been opened in this deposit just north of the town, exposing fresh gravel. The absence of gravel deposits along this portion of Maple river is in contrast with their great development along Mill creek in northern Cherokee county, and the reason for the difference is not evident.

From Maple River to Odebolt.-At the mouth of the small creek west of Galva the Iowan boundary leaves Maple river valley and runs southeast through Silver Creek and Richland townships toward Odebolt (Plate I). Along part of this course through Galva and Silver Creek townships the exact location of the boundary is not definite, and several alternative courses were considered in the field. Farther south in Richland township the boundary is more definite.

Leaving Maple river the boundary is mapped as passing southeast across sections 26, 35 and 36 of Galva township. The southeast corner of Galva township and southwestern Eureka township to the east have a topography apparently erosional, but there are slight constructional features and peb- 
bly swells in the southwest quarter of section 20 and the north part of section 32, Eureka township, and in the northwest quarter of section 25 of Galva township. West of the boundary section 35 and the west part of section 26 have a rolling Kansan topography and the road along the west line of section 26 shows several exposures of loess.

Crossing into Silver Creek township, the boundary runs south across the west part of section 4 and thence southwest across the northwest quarter of section 9 and the southeast quarter of section 8 , to the valley of Silver creek in the north part of section 17 . On crossing this valley the boundary changes its direction and runs south of east through the central part of section 16 and the south part of section 15, where it again takes the general southeast direction and crosses parts of sections 22,23, 26 and 25 (Plate I). The projection of the ice to the southwest into section 17 was down the valley of Silver creek, which facilitated the ice motion and allowed it to push farther southwest. The northeastern part of Silver Creek township is moderately rolling, with certain parts showing the billowy Iowan topography, and there are pebbly swells in the northeast quarter of section 3, at the quarter-corner on the north of section 9 and on the slope of the valley in the southwest quarter of section 9 and the southeast quarter of section 8. The western and southern parts of the township are rolling, with a much more definite erosional topography.

West of Maple river valley in southern Galva township and through Logan township there is a region of higher altitude and more rugged topography. West of Galva in sections 27 and 28 this region has a relief of 75 to 100 feet, is very rugged, and has a surface covering of loess. These conditions continue southward through Logan township. From western Silver Creek township, the rugged area across the valley is prominent, rising above the divides on the east, and the contrast between the gentle slopes of the moderately rolling topography on the east and the bold rugged topography on the west is very striking.

In southeastern Logan township the area of rugged loess-covered topography crosses to the east of Maple river valley and covers the point of the upland between Buffalo creek and Maple river. Its north edge crosses sections 25 and 30 and along this line the rugged topography changes abruptly to the gently rolling surface to the north. Exposures along the county line road in the southwest quarter of section 30, Silver Creek township, show 8 to 10 feet of loess without reaching its base. This higher rugged topography continues southeast across the southwest corner of Silver Creek township and across northern Blaine township, occupying the divide between Elk and Odebolt creeks. The decided contrast which comes at the northeast edge of this higher, more rugged area suggests strongly the possibility that the Iowan boundary may lie along this edge. 
There is, however, a belt of erosional topography about four miles wide between this area and the better developed Iowan drift topography to the east.

Southeast of the center of Silver Creek township in sections 22 and 26 there is a high, ridgelike area that has characteristics similar to those of the more rugged area to the southwest. It is loess-covered in part, shows till on some of the steeper slopes, and stands well above the surrounding region. The Iowan boundary lies along the east slope of this elevated area through sections 23,26 and 25 .

In the southeast corner of Silver Creek township the boundary approaches Elk creek valley and here there is another slight deflection from the general course. The boundary runs south across section 36 to Elk creek, and thence eastward along the south slope of the valley through the northeast part of section 1, Blaine township, and the central part of section 6 of Richland township, Sac county (Plate I). In the north part of section 8, Richland township, the boundary assumes again the general course east of south and passes through the east part of section 8 and the west part of section 16. Along this course the Kansan and Iowan drift characters are distinct half a mile in either direction from the boundary as mapped. Sections 4 and 9 to the east show Iowan drift topography, while sections 8 and 17 to the west are distinctly erosional. Good contrasting views of the two types may be had from the north line of section 8 .

The rugged loess hills noted above as coming southeastward across northern Blaine township cross sections 18 and 20 of Richland township and in the west part of section 21 the Iowan drift boundary lies along the edge of this rugged area, giving a well defined boundary. The contrast of the two topographies is well shown from the high area in the west part of section 21. The view to the east, over central and eastern Richland township, shows a rolling plain with a relief of 20 to 40 feet. The slopes are gentle, the features apparently constructional and the locations of the stream courses rather ill defined. The view to the west shows an eroded region with steep slopes and sharp crests and a relief of 100 to 150 feet. One mile to the southwest is the broad, open valley of Odebolt creek and beyond this the view extends to the high, rugged divide of southern Ida county. This region to the southwest shows the typical Kansan drift topography of southern Iowa which continues on southward beyond the southern boundary of the state.

From Odebolt to the South Line of Sac County.-At Odebolt the boundary turns eastward and runs across the end of the Iowan drift region toward the Wisconsin drift boundary. This part of the boundary is more irregular, being across the front of the ice lobe, normal 
to the general direction of ice motion, and the pre-Iowan topography caused a lobate margin. By this course from Odebolt to Boyer river, the width of the Iowan drift area is diminished to barely four miles (Plate I). The course is then southward along Boyer river valley for three miles to the Wall Lake outlet. South of the Outlet the width is still further reduced to two miles and a southeastward course soon carries the Iowan boundary beneath the Wisconsin drift.

The Iowan drift area south of Wall Lake outlet is small, comprising an area of only five to six square miles, two miles wide at the south border of the Outlet and narrowing to a point four miles to the southeast. No part of the area is more than a mile from one of the boundaries or from the Outlet. The region is moderately rolling, and, lying between the rugged loess-covered Kansan drift area on the southwest and the slightly rolling Wisconsin drift area on the east, it is distinct from either of them. On the county line on the south of section 34 , Viola township, the Wisconsin drift topography borders the rugged loess-covered Kansan drift, and so it continues on southward across Carroll county.

The erosional topography of western and southwestern Richland township continues eastward along the south line of this township and in Wheeler township to the south, thereby cutting across the general southeastward course of the Iowan drift boundary. This boundary passes southward through the east part of section 28, Richland township, and then swinging southeastward, crosses the north part of section 34 through the south part of the town of Odebolt and continues eastward through the central part of section 35 .

In northern Wheeler township south of Odebolt there is a high divide region upon which lie some rather level areas about half a mile wide that locally suggest Iowan topography. They are best developed along the divide running diagonally across sections 3,11 and 13, Wheeler township. The stream courses on the divides are at some places broad and shallow, but in a short distance from their sources the valleys become deeper and the country is more rolling.

A sewer ditch exposure near the east end of the main street of Odebolt showed three feet of mottled, brown loesslike loam overlying six feet of yellowish sand with a few pebbles and small bowlders. The exposure was 100 to 150 feet in length and showed no change laterally and the bottom of the sand horizon was not reached. This sand is just within the boundary of the Iowan drift and probably was washed out from the ice front and deposited in the waters ponded between the edge of the ice and 
the divide to the south. Five miles south of Odebolt, in sections 26 and 27 of Wheeler township, there are some pits in a gravel deposit in the valley of a southward flowing stream which heads in section 3 just south of Odebolt, and this gravel also may have been deposited by waters from the Iowan ice front, which passed over the divide south of Odebolt and escaped down this valley to Boyer river.

The region just north and northeast of Odebolt for several miles has a well defined Iowan drift topography. The adjoining parts of sections 35,26 and 25, just east of Odebolt, lie in a broad shallow depression, draining westward, and constitute the most positive case. of Iowan drift topography found near the boundary in Sac county. From the central part of section 35, Richland township, the boundary makes a broad curve to the north, passing through the south part of section 25 and the south part of section 30, Clinton township, and in the southwest quarter of section 29 comes into the valley of a small creek, down which it runs for a distance of about two miles to the northeast quarter of section 4, Levey township (Plate I). This northward curve of the boundary is where it crosses the prominent divide area to the west of Boyer river, and farther south, in the northeast quarter of section 31 and the west half of section 32 , this divide area becomes prominent and rugged and continues so southeastward across sections 5, 4 and 10 of Levey township. In section 32 and on to the southeast it has a relief of 75 to 100 feet, with very steep slopes and sharp crests, and the road cuts expose 15 to 20 feet of loess, without reaching its base. Across the valley and the boundary, in section 33, the general altitude is 30 to 50 feet lower, the surface is moderately rolling with long, gentle, faintly undulating slopes, and the loess is thin.

In the northeast quarter of section 4, Levey township, the boundary again bends northward, passes around a rugged area in sections 3 and 34 , and, running through the west and north parts of section 34 , strikes the valley of Boyer river in the northeast corner of this section. Its course is thence southward down the Boyer valley for more than four miles to the Wall Lake outlet. Along this part of the boundary the opposite sides of the Boyer valley present a contrast like that described above.

Clinton township to the north has a relief of 20 to 40 feet and contains some rolling topography and a few gravel hills. The Boyer valley, the dominant feature of the township, appears broad and open in a general view; but closer study shows that it has undulating slopes, apparently constructional. The major parts of Clinton, Boyer Valley and Cook townships present an indefinite type of Iowan drift topography, but parts of Richland township are much more definite.

The south part of Levey township, south of the Outlet, has a rough topography with a relief of 50 to 100 feet, and road cuts show thick 
loess exposures. This continues northward to the valley of a small creek flowing northwest across the northeast quarter of section 25 and the southwest quarter of section 24 . North of this valley, in section 24 and east in section 19 of Viola township, the general altitude and relief is less, the topography is less rugged, although the whole is well drained, and loess cuts are not found. The Iowan boundary passes up this valley through sections 24 and 25 and continues in Viola township diagonally across the south half of section 30 , the north half of section 32 and the south-central part of section $3 \dot{3}$ to the Wisconsin drift boundary, under which it passes in the southeast quarter of section 33 (Plate I). In sections 32 and 33 the boundary follows the base of a slope rising to the higher, rugged area to the south.

\section{INTERBEDDED GRAVEL AND TILL}

Exposures showing till interbedded with sand and gravel were seen at a number of places within the Iowan area, especially in northern Cherokee county. The sand and gravel are mostly fresh and the gravel is mostly fine-grained. Coarse sand with pebbles scattered through it is common. Some of it is distinctly bedded and some shows no stratification. Locally the gravel is cemented by a calcareous cement and so forms irregular masses of firm conglomerate; or cementation may affect the whole or part of a stratum over a considerable area. Cementation is more common at the top of the gravel zones than at the base and apparently is more common on the face of an exposure than farther back from it.

\section{Distribution and Description of Exposures}

By far the greatest example of the interbedding of gravel and till observed was found in the east bluff of Mill creek in the west half of section 14, Cherokee township, three miles north of Cherokee. Mill creek at this place flows against the base of the east slope of its valley, and this slope rises very steeply 100 to 120 feet to the crest of a narrow ridge which overlooks the valley of Mill creek on the west and the Little Sioux valley on the east. The good exposures were just south and north of the line through the center of section 14, were distributed through a distance of about 80 rods, and were found in little gullies and slides that gave exposures of the underlying material. The lower 30 to 40 feet of the valley slope is gentle but showed a few exposures of the typical Kansan till. Above this is a steep slope of 75 to 100 feet, consisting of about equal parts of interbedded Iowan till and gravel which alternate several times in the vertical section. The gravel 
horizons range in thickness from mere seams to 20 feet, but a common thickness is 10 to 15 feet.

Most of the gravel is fresh and has a light color owing to the predominance of gray limestone pebbles. It contains many clay-ball pebbles from the associated Iowan till and some of Kansan and $\mathrm{Ne}$ braskan tills. The interbedding of gravel and till and the presence of

A

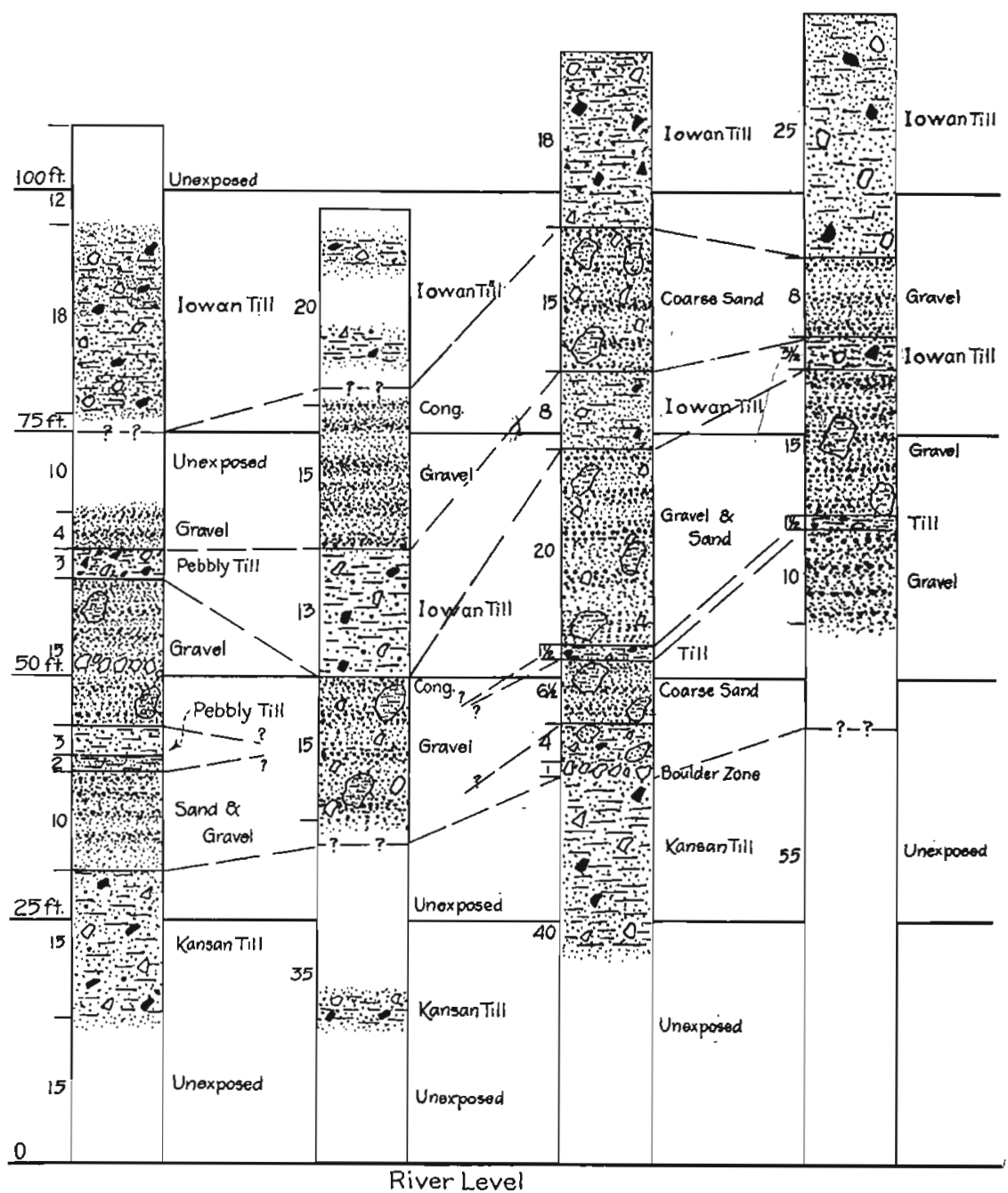

FIG. 12,-Columnar sections of exposures in the east bluff of Mill creek in the west half of section 14, Cherokee township. The probable correlation of the zones of the several sections is indicated. 
the clay-balls of the associated till in the gravel show that the gravel belongs to the same stage as the till.

These exposures in the Mill creek bluff of section 14 were such good ones that the following sections are given, recording in detail the succession found in several of the better exposures. The exposures were all mere gully washes and were partly obscured by slumping and surface accumulation. The sections are given in order from south to north.

Section $A$.-The most southern exposure, that covered approximately all of the height of the slope, was 30 to 40 rods south of the quarter-section line. This exposure is shown diagrammatically in $\mathrm{A}$ of figure 12 .

11. Grass-covered, gravelly, clay slope rising to the top of the ridge, which is here 106 feet above the creek. Probably Iowan till, but it

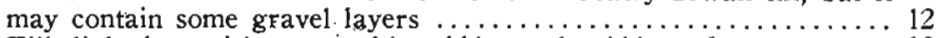

10. Till, light brownish gray, with pebbles and cobbles. Iowan ....... 18 The exposure is not entirely continuous and the division may contain some gravel. Numbers 11 and 10 combined would make a till zone 30 feet thick, which is greater than for any single zone of till known along this bluff. There is also the unexposed zone (9) below, which may be largely till. It is not probable that numbers 11,10 and 9 form a single continuous till zone, or even that numbers 10 and 11 are without a single gravel layer.

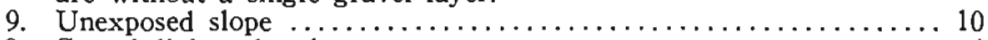

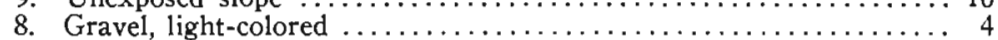

7. Till, light brownish gray, with pebbles, cobbles and small ocherous masses. In some places the pebbles and cobbles make up fully half of the whole. The basal contact on the gravel is very sharp, without any alteration or deformation of the gravel ................

6. Gravel with large pebbles and bowlders scattered through it and a layer of bowlders about 5 feet above the base. Many included clayballs and masses of Iowan till are present. The gravel has a light color and limestone is the dominant material. Shale pebbles are quite abundant. This is the typical gravel associated with the fresh

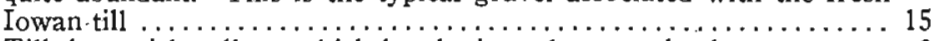

5. Till, brownish yellow, which breaks into elongate chunks ....... 3

4. Till, brownish blue-gray, sandy ........................ 2

3. Sand and gravel; at top a fine-grained, yellow sand; only partly

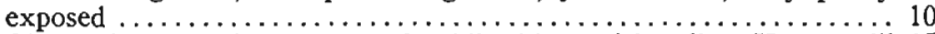

2. Slope with several exposures of oxidized brownish yellow Kansan till 15

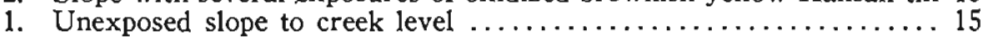

Numbers 1 and 2 of this section are Kansan till. Above these the Iowan section gives at least three gravel zones and three till zones, and a better exposed section probably would increase the number.

Section B.-The gully just north of the quarter-section line fence exposed the following, beginning 98 feet above the creek and passing downward. The columnar section is shown in B of figure 12 .

5. A pebbly clay slope with a few exposures of brownish gray till .... 20

4. Gravel horizon; cemented to a conglomerate near the top ......... 15

3. Till, brownish yellow-gray; harder and more compact than number 5. Where it is fresh it breaks into irregular chunks and crumbles to a sandy clay. The lower 3 feet includes much gravel ........... 13 
2. Gravel, light colored, with pebbles, cobbles, clay-balls, and some larger

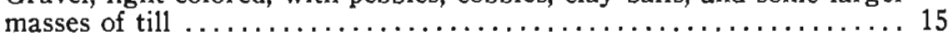

In the gully the upper 2 feet of this horizon is cemented, forming a calcareous conglomerate, but this does not continue horizontally beyond the gully. The lower part of the slope is so badly slumped that the lower contact of the gravel could not be exposed.

1. Unexposed to creek level, except for one small outcrop of oxidized, brown Kansan till at 15 feet above the creek ................. 35

This section shows two distinct layers of fresh gravel, each at least 15 feet thick, and each overlain by Iowan till. A cemented horizon is found at the top of each gravel zone. The cementing material is calcareous and the cementation is sufficient to make firm conglomerate, large blocks of which lie on the slope below the outcrop. The cemented parts differ in thickness and seem to be irregular cemented masses rather than continuous beds. This cementation is due to the evaporation which takes place when ground water percolating downward passes from the compact till to the porous gravel. If the water has become saturated with calcareous material this evaporation will cause deposition.

Section C.-This exposure was in a gully about 40 rods north of the quarter-section line fence. It is shown in $\mathrm{C}$ of figure 12 .

FEET

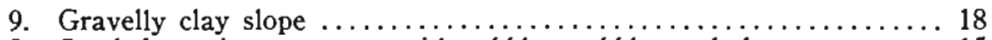

8. Sand, ferruginous, coarse, with pebbles, cobbles and clay masses .... 15

7. Till, sandy, brownish gray, breaks out in irregular chunks and pul-

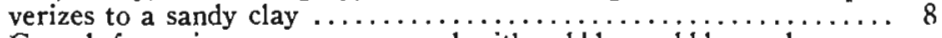

6. Gravel, ferruginous, or coarse sand with pebbles, cobbles and numerous large clay masses, some of which are 2 to 4 feet across ........ 20

5. Till, bluish gray, with brown streaking along joints .............. $11 / 2$

4. Sand, coarse, with pebbles, a few cobbles and clay-balls. The lower 18 inches is about half clay in the form of clay-balls ............ $6 \mathrm{x} / 2$

3. Till, yellowish brown, with many pebbles and pockets and seams of

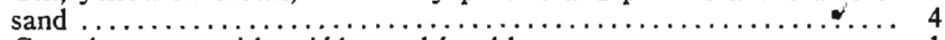

2. Gravel, coarse, with cobbles and bowlders ........................ 1

1. Brown Kansan till was exposed for 18 inches below the top of the zone and at one point 10 feet lower. Remainder of division to creek

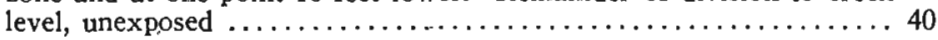

Section D.-At the place where the bluff begins to bend to the west there is a gully which branches about 50 feet above the creek. The following exposure was seen in the north branch of this gully. It is represented in $\mathrm{D}$ of figure 12 .

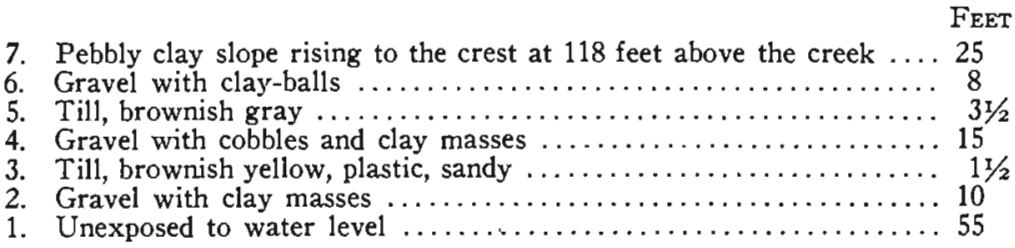

Several other exposures to the north show a part of the section and in every case where more than a few feet is exposed an alternation of gravel and till is to be seen. 
The beds of all these gullies are filled with bowlders. Pink and gray granite of the fine-grained type predominate, but basalts are numerous and limestones are more prominent than is common among bowlders.

The sections given above show two, three and four gravel horizons, and few of the exposures were continuous enough to demonstrate that other thin gravel layers are not present. Some similarities of sections which are very close together were noted, but on the whole it appears that the individual horizons are not continuous through the length of the bluff. Figure 12 shows such correlations as can be made between the various members of the several sections.

The fresher till interbedded with gravel in the upper parts of the exposures just described is interpreted as Iowan. The till exposed in the lower 30 to 40 feet of the bluff is darker and firmer than that which is associated with the gravel beds and is interpreted as Kansan. In the lower ends of several of the gullies toward the north end of this bluff the Nebraskan drift is exposed.

At several places in the exposures described above the interbedded gravel contains such a great number of clay-balls that they constitute a very important part of the whole. These clay-balls indicate that the material had not been carried far before deposition, for clay material could not have withstood the wear incident to long transportation, even though it were firmly frozen. As the clay-balls were formed probably on or near the edge of the ice sheet, their presence indicates the nearness of the ice front at the time of gravel deposition.

The banks of the creek valley in section 24 of Cedar township, Cherokee county, east of Larrabee, show a number of small exposures with gravel and sand associated with the till. Examples appear a few rods to the north and to the south of the east-west quarter-section line. None of these exposures is very extensive, and it is not clear whether these gravel zones are within or at the base of the Iowan till. Farther down the creek valley exposures of gravel, sand and silt associated with till may be seen at a number of places. Some of these gravels evidently are included masses, while others may be gravel zones of some extent. A conglomerate ledge projects at one place, and elsewhere masses of conglomerate lie on the surface. The valley slopes are quite completely grassed over, but if good exposures existed the section might be somewhat similar to that of the Mill creek bluffs described above.

At various other places examples of gravel layers interbedded with 
the till were seen, which indicates that the phenomenon may have a rather general distribution, but nowhere else are the interbedded layers known to be so numerous as in the Mill creek bluffs north of Cherokee.

In the till of northwestern Iowa there is a considerable quantity of gravel and sand in the form of inclosed masses. Many of these masses are in till exposures within the area of Iowan drift, but some are in the area of the Wisconsin drift and some in the Kansan drift region. All these inclosed masses will be treated in the discussion of the Kansan drift region (pages 111 to 115 ).

\section{Origin}

The advance of the edge of an ice sheet probably is really a succession of advances and retreats in which the advances are greater than the retreats. Likewise the general period of retreat of the ice edge may be broken by temporary advances. Between these two general periods there is a longer or shorter time when the oscillations approximately balance each other and the general position of the ice edge remains nearly constant. These oscillations may be due to seasonal changes or to changes taking place over longer periods. Gravel deposited beyond the front of the advancing ice sheet soon may be overridden by the ice and covered with a deposit of till. If now the ice edge withdraws temporarily, gravel may be deposited on top of the till only recently laid down. Readvance of the ice would result in a second till horizon, and so with several oscillations several alternations of till and gravel might be formed. It is not necessary to assume any great oscillations of the ice front, for none of the gravel horizons noted above has been shown to cover any considerable area. An oscillation of a fraction of a mile, or a few miles at most, would be adequate. The greatest known succession of till and gravel horizons, that of the Mill creek bluffs north of Cherokee, is at the edge of the Iowan drift sheet, and it is probable that the greatest and most frequent oscillations would take place at the time of maximum extent of the ice sheet.

Gravel deposited near the edge of the ice, in the way just outlined, would be of the outwash type, consisting of fresh, unweathered material with some pebbles of soft rocks, and would rest on fresh till. The gravel of these horizons is, therefore, interpreted as having been deposited just beyond the front of the ice sheet during the oscillations that took place at the general stage of maximum advance or during the minor oscillations within the stages of advance and retreat. 


\section{THE GRAVEL HILLS}

At a number of places within the area of the Iowan drift there are mounds composed of gravel and sand. Their slopes are gentle and few of them rise more than 15 to 20 feet above their surroundings. In form they resemble the kames of the Wisconsin drift, though they are much less conspicuous. Some of them are isolated, and some are in groups.

\section{Nature of the Gravel}

The gravel of these hills is as a rule fresh or but slightly altered. Some of the exposures, however, show highly oxidized and leached gravel near the surface and a few show ăn abundance of chalky, calcareous material either as weathered limestone pebbles or as matrix between the pebbles.

As in all types of gravels of our region, gray limestone pebbles predominate to such an extent as to make a light-colored gravel. In twenty-one analyses made in the gravels of this type the limestone pebbles average 55 per cent of the whole. Shale pebbles are present and in certain layers are even abundant. Grains of shale also are abundant in the sand. A characteristic and distinctive feature of these gravel hills is the presence of small rounded masses of glacial clay (clay-balls) among the pebbles. These differ in size from a fraction of an inch to six inches in diameter. They are recorded in nineteen of the twentyone analyses of gravel from these hills and the average for the twentyone analyses is 12 per cent. The percentage is 26 or below in all analyses but one, where it is 59 . The igneous rock content ranges from 8 per cent to 48 per cent, the lowest percentage being due to the large number of clay-balls. Counting the clay-balls as sedimentary the average total of sedimentary rocks is 76 per cent, and the average total of igneous rocks is 24 per cent. The analyses of pebbles from the gravel hills are tabulated in Table IV, page 175.

The percentage of giranite and other igneous pebbles generally is low in comparison with that shown in analyses from gravel deposits of other types. This is due to the large number of clay-balls in these gravels, which by their presence lower the percentage of all other kinds of pebbles. The decrease, however, comes mainly in the igneous pebbles, for the comparison is with gravels that have been more waterworn, and which therefore contain a smaller percentage of pebbles of the softer materials. Chief among these softer pebbles are the clay- 
balls, which would be destroyed by wear and thus would increase the percentage of all other kinds. But some pebbles of other soft materials would be destroyed by the transportation, so that the increase would be most apparent in the harder types. The increase in the percentage of limestone pebbles due to the destruction of clay-balls apparently was offset by the destruction of some of the softer limestone pebbles, with no apparent gain in limestone.

If these gravel hills are kames or some other type of deposit directly associated with the ice, softer material would naturally be more abundant than in gravels that were subjected to longer transportation and wear. On the other hand, waters flowing well up in an ice sheet, as may be the case with waters forming kames, probably would yield a larger precentage of igneous pebbles than waters draining from the base of the ice.

There is in some cases a great range in the composition of the gravel in the same hill. This is particularly prominent in the case of shale pebbles, for certain layers contain a percentage far above normal, and some layers are made up almost entirely of small grains of shale. In other constituents also there is in some cases a considerable lrange. No differences were detected that differentiate the deposits of different localities. Analyses from gravel hills a hundred miles apart are as likely to be similar as those from hills near together.

\section{Distribution and Description of the Gravel Hills}

Many of the gravel hills of the Iowan drift region are within a few miles of the outer edge of this drift sheet and have been mentioned under the discussion of the Iowan boundary (pages 59 to 84). Some of these may come in for fuller treatment under this heading and others back from the boundary will be considered. The locations of the better developed of these hills, including many of those here discussed, are shown on Plate I by a hollow square.

Northeastern Lyon County.-The northeast corner of Lyon county, north, northwest and west of Little Rock, contains the most conspicuous examples of these hills in the Iowan area (Plate I). Most of them are below the general upland level on the slopes of Little Rock river valley. Most of them rise only 10 to 15 feet above their surroundings, but one in the southeast quarter of section 23 rises 25 feet above its surroundings.

A group of hills just north of Little Rock, near the center of section 26, contained several gravel pits in relatively fresh material. A pit in the 
high hill in the southeast quarter of section 23 showed 15 feet of coarse gravel and fine sand with many clay-balls, some of which are six to eight inches in diameter. The gravel is unleached but well oxidized and some of the coarse granite and dark igneous pebbles are decomposed. This is a good example of a kamelike hill.

In the southwest quarter of section 27 there are a number of gravel hills with a distinct constructional topography, and one at the southwest corner of the section shows a coarse somewhat rusted gravel in which the coarse-grained igneous pebbles crumble readily. The gravel of this exposure, as well as that of section 26 , contains many clay-balls. Other low gravelly hills, without exposures, are found in the west half of section 34 and the east half of section 33 .

Southwestern Nobles County, Minnesota.-A large number of gravel hills are found in the southwest part of Adrian, Minnesota, and in the northeast quarter of section 23, half a mile farther southwest. This is within the more hilly belt along the margin of the Iowan drift in Minnesota and the kamelike hills here are larger and more prominent than anywhere to the south in Iowa. A road cut in one of these hills on the north line of the northeast quarter of section 23 showed a great mixture, including coarse dirty gravel with clay-balls; ferruginous bowldery deposits in which many of the dark igneous bowlders are rotten; fine fresh. sand; great masses of till; and mixtures of gravel, bowlders and till. The areas north of Little Rock and southwest of Adrian were interpreted by Professor Wilder as parts of the Altamont moraine of Wisconsin age. ${ }^{31}$

Three miles south of Adrian, in the southwest quarter of section 36, West Side township, a pit in a low hill on the north slope of a shallow valley showed in part coarse pebble beds and in part fine gravel and sand. Clay-balls are abundant in the coarser part, one analysis giving 16 per cent. The coarse-grained, dark igneous pebbles crumble easily and most of the limestones are coated brown. In a part of this hill the layers are steeply inclined, and in these layers the laminæ, locally, have an angle of 80 degrees.

Western Osceola County.--In the west part of Osceola county there are low gravel hills on the north slope of a broad, shallow valley in the west part of section 5, West Holman township, and 6 miles south in the southwest quarter of section 5 and the southeast quarter of section 6 of Gilman township. In the hill in southwest 5, Gilman township, a pit exposure showed about three feet of coarse ferruginous gravel resting upon fresher finer-grained material. Clay-balls are very abundant, amounting to 25 per cent of the total contents in one analysis, and on the pit face one was exposed for each square inch of surface.

81 Iowa Geol. Survey, Vol. X, 'pp. 132-135, 1900. 
Northern O'Brien County.-Gravel hills are found along the headwaters of Floyd river in northern Franklin township of O'Brien county. They are present along a tributary valley in the southwest quarter of section 4 , where some gravel pits have been opened, and along the main valley in the southeast quarter of section 4 (Plate I). The exposures seen were shallow and the gravel was strongly oxidized. A low hill just northwest of Sheldon in the central part of section 25, Grant township, Sioux county, is probably a gravel hill.

In a pit in a low mound 3 miles northwest of Hartley, near the center of section 24, Lincoln township, the gravel had been worked out in several places and there was exposed a vertical contact between the gravel mass and the till. This gravel mass, partly inclosed within the till, occupies an intermediate position between the gravel hills and the included masses of gravel. Farther east, in Waterford township of northeastern Clay county, there are several low hills or mounds apparently composed of gravelly material.

Along Willow Creek in Southern O'Brien County.-One of the regions of greatest abundance of the gravel hills is along Willow creek west of Calumet in southern O'Brien county, where more than a dozen of these hills are present in the north parts of sections 22,21 and 20 and the south parts of section 16 and 17, Liberty township (Plate I). About half of these have exposures showing sand and gravel. The two best exposures are in gravel pits in the north part of section 22 and will be described somewhat in detail.

Near the quarter-section corner on the north of section 22 there is a low mound near the top of the valley slope with a pit 20 to 25 yards across and 10 to 15 feet deep. The material exposed is sand and fine gravel, with some very fine-grained horizons showing extremely fine
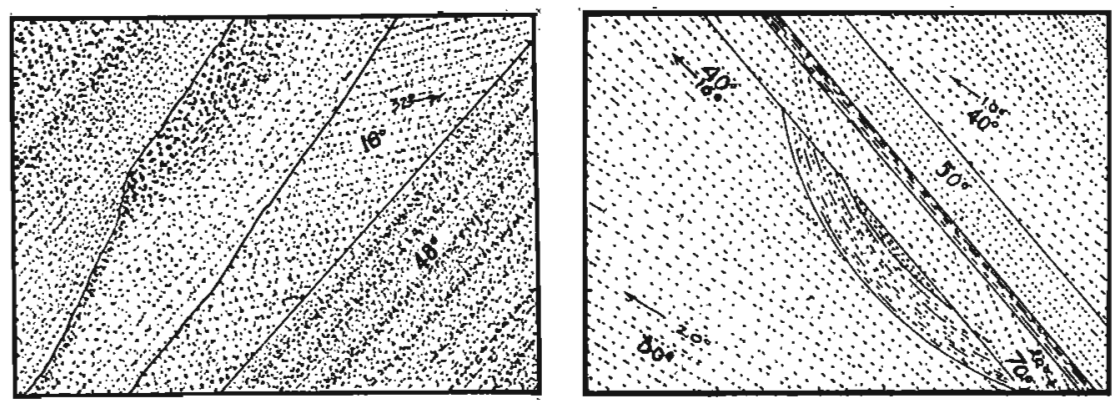

Frc. 13.-Sketches showing cross-bedding and basin structure of sand exposed in a pit in a gravel hill in the northwest corner of the nortbeast quarter of section 22 , Liberty township, O'Brien county. The present inclination of the beds is given in the more prominent figures. The direction of inclination before the tilting of the gravel mass is indicated by the arrows, and the angle by the less prominent figures. The position of the beds at the time of deposition may be shown by tilting the figure on the left, to the right about 50 degrees, and the figure on the right, to the left the same amount. 
lamination. Throughout the lower part of the mass the horizons are inclined, with a strike N. $25^{\circ}-30^{\circ} \mathrm{W}$. and a dip of $45^{\circ}-50^{\circ}$ in a direction south of west. The individual horizons are cross-bedded and laminated. Where the tilting of the mass increased the inclination of the cross-bedding laminæ, these now stand at an angle of $60^{\circ}-70^{\circ}$. Where the laminæ were originally inclined in the direction opposite to the direction of tilting of the mass, the original inclination was overcome and the laminæ are now inclined $20^{\circ}$ to $30^{\circ}$ in the opposite direction (figure 13.)

Gray limestone pebbles are by far the most abundant, forming 66 per cent in one analysis. A few shale pebbles appear in all the material but are most abundant in the finer gravel layers, where they form a third to a half of the whole number, and decrease in abundance with the increase in size of the pebbles. Interbedded with these layers containing much shale are other layers of nearly the same coarseness that have only a few shale pebbles.

The following section records the material shown in this pit which dips to the southwest (figure 14).

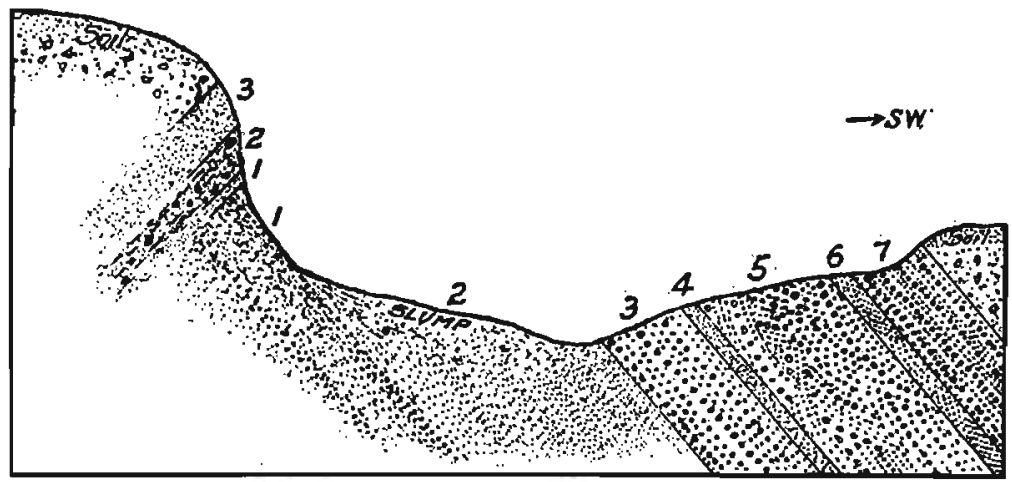

FIG. 14.-Cross section of a pit in a gravel hill in the northwest corner of the northeast quarter of section 22 , Liberty township, O'Brien county, showing the structure and the relation of the parts described in the text. The numbers on the figure are the numbers of the zones of the sections recorded in the text.

FEET

7. Reddish gravel, fine-grained $\ldots \ldots \ldots \ldots \ldots \ldots \ldots \ldots \ldots \ldots \ldots .4$

6. Sand, very fine-grained, yellowish gray, cross-bedded and finely lami-

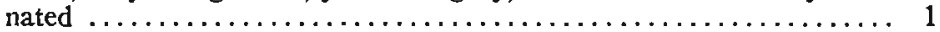

5. Sand, coarse, and fine gravel; laminated and cross-bedded in part;

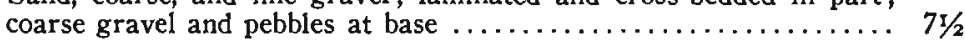

4. Sand, fine-grained, cross-bedded $\ldots \ldots \ldots \ldots \ldots \ldots \ldots \ldots \ldots \ldots \ldots$

3. Sand and fine gravel; some layers contain much shale $\ldots \ldots \ldots \ldots \ldots, 41 / 2$

2. Slumped slope of fine sand $\ldots \ldots \ldots \ldots \ldots \ldots \ldots \ldots \ldots \ldots \ldots \ldots \ldots \ldots \ldots$

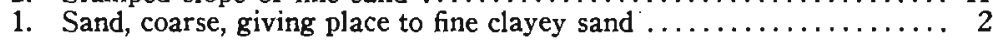

Resting across the edges of the lower horizons of the section just noted and exposed in the east face of the pit are the following: 


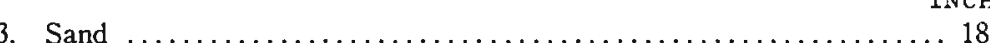

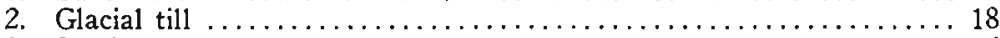

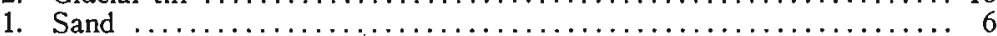

These three members have a strike similar to that of the horizons below but dip in the opposite direction (northeast) at an angle of about $50^{\circ}$ (figure 14). The till horizon thins to left and right, forming in the pit face a lens-shaped exposure about 1.5 feet long. It may be either a mass of till put down upon the large gravel mass or the thinning edge of the surrounding till, which appears partly to inclose the gravel mass. If the gravel were entirely worked out the contacts might throw much light on the relation of the gravel masses and the till. Above these three members in the pit face is a jumbled mass of pebbles, bowlders and clay material 3 to 4 feet thick and then a sandy, pebbly soil horizon of 2 feet.

Just south of the northwest corner of section 22 is a large pit in a gravel hill on the south slope of the valley. This is the largest of these hills along this creek and rises 40 feet above the stream, although its top is only slightly higher than the upland just to the south. The material here is somewhat coarser than that in the last pit described. Clay-balls are quite abundant in some zones and average 20 per cent in three analyses. They range in size from small pebbles to masses 6 to 8 inches across. The material is stratified and the horizons are inclined with a strike $\mathrm{N} .45^{\circ}-50^{\circ} \mathrm{W}$. and a dip of about $20^{\circ} \mathrm{SW}$. The following section is exposed in this pit.
10. Soil, gravelly
FEET

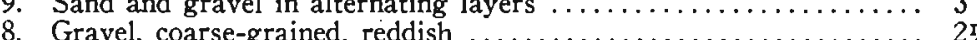
7. Sand, fine-grained, cross-bedded $\ldots \ldots \ldots \ldots \ldots \ldots \ldots \ldots \ldots \ldots \ldots$

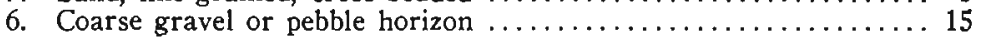
Contains numerous clay-balls ranging in diameter from 1 to 8 inches. This horizon is quite variable and at the east end of the pit it contains a 4-foot layer of fine cross-bedded sand, which thins out entirely in 40 feet to the west. At the central part of the pit face it is very bowldery. At the west end it is fine gravel with a few pebble layers.
5. Sand, coarse, and fine gravel, poorly exposed. Some of the gravel

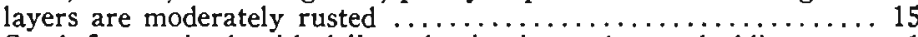
4. Sand, fine-grained, with delicate lamination and cross-bedding $\ldots . . .11 \frac{1}{2}$ Horizontally this grades into coarse sand not distinguishable from No. 3.
3. Sand, cross-bedded, grayish, with a large percentage of grains of shale. Some layers are so largely of shale that they are sticky like clay when moist ................................ 21/2
2. Sand, coarse, reddish, cross-bedded, containing clay-balls in upper part. Only partly exposed $\ldots \ldots \ldots \ldots \ldots \ldots \ldots \ldots \ldots \ldots \ldots . . . \ldots$
1. Sand, fine, yellow-gray, poorly exposed ................. 10

In the north part of section 21 and the south parts of sections 16 and 17 , farther down Willow creek valley, there are more of these hills, several of which show shallow exposures of gravel. In the southeast quarter of 
section 17 a small abandoned pit in one of these hills (figure 15) showed gravel, from which a pebble count was made which contained 59 per cent of clay-balls.

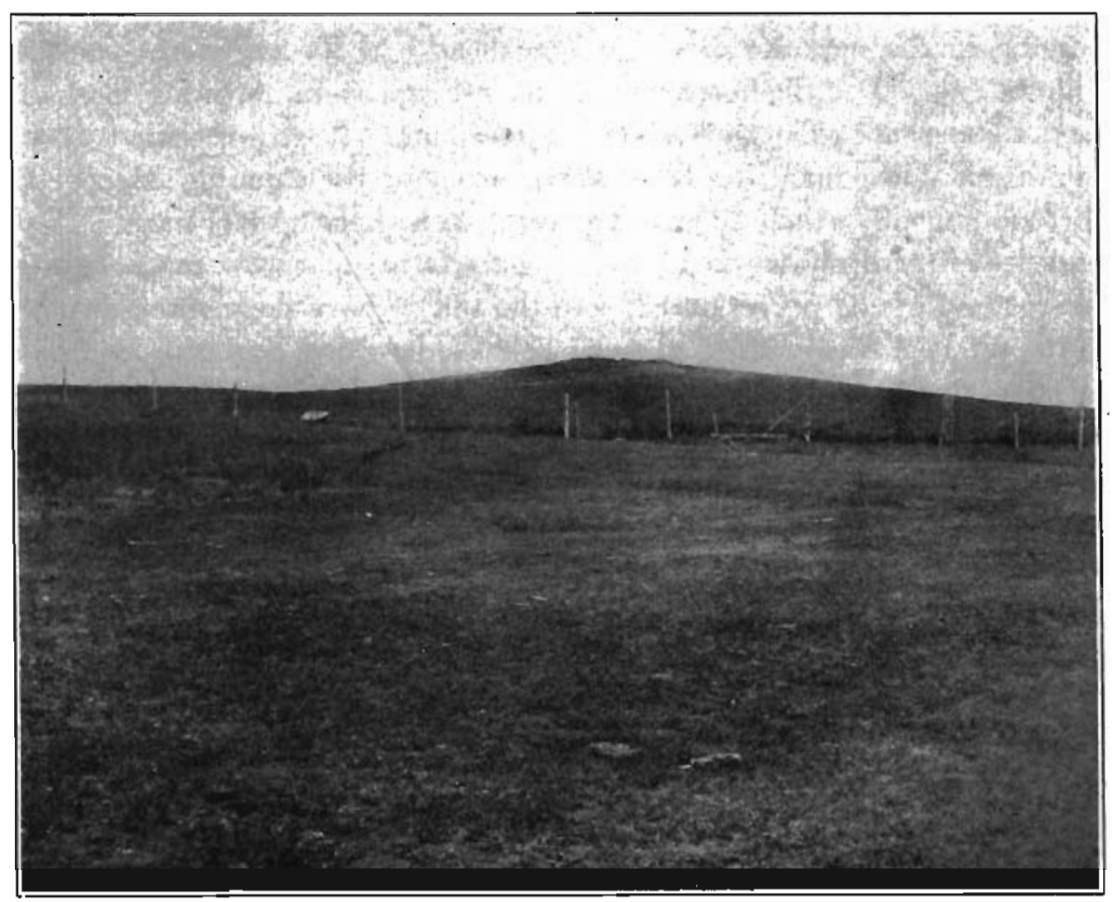

Fyc. 15.-View of a gravel hill of the Iowan drift region on the north slope of Willow creek valley in the southeast quarter of section 17 , Liberty township, O'Brien county.

Northern Cherokee County.-Near the south line of section 10, Cedar township, Cherokee county, a mile north of Larrabee, there is a gravel hill that has been worked for a number of years. It is located on a divide and stands 10 to 15 feet above its surroundings. Another hill about half a mile to the north is of similar size. A pit exposure in the first hill showed relatively fresh coarse gravel in inclined layers. Clay-balls are plentiful and some are as much as 6 inches in diameter, and the pit face showed a lens of till 5 feet long and 4 .to 8 inches thick. This hill was mentioned by Macbride in his report on Cherokee and Buena Vista counties and was interpreted as being "part of a continuous series of such deposits extending from Sibley south and east, including the gravel pit at Sheldon and similar deposits about Calumet." 32 The deposits at Sibley and Sheldon are valley deposits, while the "deposits about Calumet" probably refers to the

32 Iowa Geol. Survey, Vol. XII, p. 322, 1902. 
gravel hills along the headwaters of Willow creek, described above. The suggested "continuous series of deposits extending from Sibley south and east" does not exist, although there are several points to suggest such a series.

One mile south of Larrabee, on the east side of the railway, at the center of the northwest quarter of section 26 , an abandoned pit in one of these hills showed a rather rusty gravel with many clay-balls. In the north half of the southwest quarter of section 34 are several hills, one of which has an exposure showing the usual light-colored gravel with clay-balls.

Southeastern Cherokee County.-In southeastern Cherokee county there are gravel hills at many places in Pitcher and Diamond townships. They are most numerous along a ridge which extends from the northwest quarter of section 28, Pitcher township, southeast across this section and south through the east part of section 33. Pebbly mounds appear on this ridge just northwest of the center of section 28 , in the southwest quarter of section 28 , at the northeast corner of section 33 , and at a number of places in the east part of section 33. A group of hills near the quarter-corner on the east line of section 33 has been worked for sand for many years. There are other pebbly hills near the center of section 21 and in the northwest quarters of sections 22 and 9 . The pebbles, as exposed at the surface of the mounds, show only the hardest varieties of rock, but in the pits and road cuts on the east line of section 33 all the usual kinds of pebbles are present, with some clay-balls. The material in general is more ferruginous than is common farther north, but in the pits just noted there is much fresh fine-grained sand. Gravel hills containing very ferruginous sand appear also in the east part of section 4, Diamond township.

In the northeast quarter of section 35, Diamond township, there is a group of gravel hills which extends also into the adjoining corners of sections 26 and 25 (Plate I). These hills have been extensively used for road material and show a number of poor exposures. At several places the gravel is very rusty and reddish and at places the coarser material is leached to a depth of several feet. Elsewhere it is calcareous to the surface and at no place does the leaching or strong oxidation go to a greater depth than 5 feet, even in the coarser material. One exposure about 100 feet across showed essentially horizontal zones, within which are inclined laminæ and cut-out structures, suggesting deposition in great moulins in the ice rather than as kames at the edge of the ice. In the northeast part of section 25 there is an isolated steep-sided kamelike hill on the south slope of Little Maple river valley.

The great alteration of the gravel of many of the gravel hills of Diamond township raises the question whether they are of the same age as the 
hills farther north. Their position would make them Iowan, but the material in some of them looks older. However, alteration is not merely a matter of age. The more frequent the alternation of the presence of water and air in the gravel, the more rapid the alteration. Neither water nor air remaining permanently in a deposit will produce much change. The hills of section 35 are in a region of considerable relief where there would be fairly rapid motion of the ground-water and a great fluctuation of the ground-water table with each successive period of rain. Under these conditions oxidation and leaching would be more rapid than in the more level regions farther north.

Ida and Sac Counties.-Gravel hills and pebbly swells exist at several places along the Iowan drift boundary through northeastern Ida and western Sac counties, all of which have been considered sufficiently in connection with the discussion of the Iowan boundary (pages 79 to 84). Farther east, just southeast of Early, in the north-central part of Sac county, only one to three miles from the Wisconsin drift boundary, gravel hills with pit exposures are found in the southwest and northeast quarters of section 10, Boyer Valley township. The material seen in the pit in the southwest corner of the section consists of well oxidized gravel and fresher cross-bedded sand. The coarse-grained igneous pebbles and cobbles and even some of the limestone pebbles are largely decomposed. The surface of the hill on which the water tank is located at Early is pebbly, and 5 miles south of Early a low gravel hill is located just east of the southwest corner of section 34 .

In his report on Sac and Ida counties, Macbride mentions gravel deposits in and about Early $;^{38}$ gives pit sections from both the gravel hills of section 10; and shows gravel pits on the Sac county map in section 10 southeast of Early and in section 31 west of Lake View. Concerning these gravel deposits, he says they "represent probably an overwash from the drainage of the Wisconsin front". All these hills are well up toward the top of the divide between Boyer river and Indian creek, one to two miles west of the Wisconsin drift margin, which lies along Indian creek valley. Iowan drift topography intervenes between this drift margin and the gravel hills, and there is no evidence that the Wisconsin ice occupied any part of the area west of Indian creek or drained across this divide. The topographic position of the hills and their isolation from the Wisconsin drift margin show that the material was not derived from the Wisconsin ice margin.

One mile north of Wall Lake, in the central part of section 1, Levey township, there is a group of gravel hills, covering 15 to 20 acres, which

38 Iowa Geol. Survey, Vol. XVI, p. 540, 1906. 
have been extensively worked for a number of years for road ballast. The material here is light-colored gravel with a high percentage of limestone pebbles and is much fresher than most of the material of the hills south of Cherokee. In one of the pits there is much light yellow siltlike material mixed with the gravel. Gravel hills are present also along the west line of section 1. In Clinton township they are present in the northeast quarter of section 32, the northwest quarter of section 35 and the southwest and northeast quarters of section 26.

A few gravel hills are found in the Iowan drift area south of Wall lake outlet. In the north part of the southwest quarter of section 19, Viola township, a pit on a valley slope exposes a fine gravel with much limestone. Clay-balls are abundant and the material is evidently of the gravel hill type. Gravelly swells are found also near the quarter-corner on the south of this section. In the northeast quarter of the southwest quarter of section 20 there is a gravel pit in a shoulder on the east slope of the valley that forms the Wisconsin drift boundary. The material is a dirty gravel containing many clay-balls and masses of till. This appears to be one of the gravel hills which characterize the Iowan drift region, although the surface just to the east shows Wisconsin drift topography.

\section{The Origin of the Gravel Hills}

As to the origin of the gravel hills, four hypotheses will be considered. (1) The hills are kames formed during the retreat of the Iowan ice sheet. (2) They consist of gravel deposited in great moulins or wells in the ice, which, on the melting of the ice, was let down on the drift surface. (3) They consist of masses of pre-Iowan gravel plowed up while in a frozen condition by the Iowan ice sheet and incorporated as gravel bowlders with its debris. When the ice melted these gravel masses were left at or near the surface of the Iowan drift sheet. (4) They consist of masses of gravel plowed up by the Iowan ice sheet and left at the surface of the Iowan drift as in (3), but the gravel is of Iowan age, having been deposited by the waters flowing out from the front of the advancing Iowan ice sheet, which a little later plowed it up.

Before discussing these hypotheses we will summarize some of the evidence which bears upon them.

Evidence of Structure.-Most of the gravel is stratified, and many of the individual layers are themselves beautifully cross-bedded and finely laminated. Most of the deposits that are adequately exposed show the layers inclined at a considerable angle. In the pits just north- 
west of Calumet the gravel layers have an inclination of 58 degrees, while some of the cross-laminæ are inclined as much as 70 degrees (figure 13). Other masses showing tilted layers are found in section 10 , one mile north of Larrabee, and in the southwest quarter of section 36, three miles south of Adrian, Minnesota, where cross-laminæ have an angle of 80 degrees (page 92). These angles are well above the highest possible angle of deposition, and the strata have come into their present position by a tilting of the mass since the deposition of the gravel. The strike and dip of the beds in most cases are uniform in a particular gravel hill, indicating that the tilting affected the gravel mass as a unit.

Evidence of Location.-Most of the gravel hills are located along valleys or on the slopes of valleys. The most notable instance of their location along valleys is along Willow creek, west of Calumet, in southern O'Brien county, but other examples were noted in northern . Franklin township of O'Brien county, five miles west of Sibley, and three miles south of Adrian, Minnesota. The pronounced development of these hills north and northwest of Little Rock (page 91) is within or on the slopes of Little Rock river valley. From the valleys these hills may appear prominent, but their tops are seldom higher than the upland; and from the upland they are hardly recognizable. Some of the hills are located on divides, entirely independent of stream courses. No single topographic position will include them all and no hypothesis that hinges upon a topographic association can meet all the necessary conditions.

Evidence of Material.-One of the characteristics of these gravels is the presence of the clay-balls seen in most of the exposures. Balls of clay, even when frozen, cannot be supposed to have withstood the wear of transportation by running water for a very long time, and these clay-balls, therefore, indicate that the material was not carried great distances before deposition. The large percentage of shale and other soft materials found in some of the exposures and the prevalent subangular form of the pebbles point to the same conclusion. This evidence is against any hypothesis that would make the gravels interglacial, for interglacial deposits should be of well rounded pebbles and consist of only the harder materials.

The clay composing the clay-balls is typical Iowan till, and therefore the gravel containing them cannot be older than the Iowan ice sheet. 
But the gravel containing the clay-balls is at many places partly inclosed in Iowan till, and there seems to be no division between these masses and those completely inclosed in the till and likewise containing clayballs. The deposit cannot, therefore, be younger than the Iowan ice sheet.

In general appearance these gravels look very much like the gravel masses included in the till, like the gravel interbedded with the till, and like the valley gravels. The pebbles of the gravel are very much like those of the Iowan till, and from its general appearance the gravel might have been derived from this till.

Conclusions. - The first hypothesis listed above (page 99) would make the hills Iowan kames. Kames would be largely on the surface, although their basal parts might go down into the till sheet, as these gravel masses do in most cases. However, the uniformity of dip throughout any one of the hills, the distinctly bedded character of the material, and the well developed lamination and cross-bedding show a regularity too great for kame deposits. Some of the more irregularly arranged and heterogeneous deposits, as that shown in the road cut on the north line of the northeast quarter of section 23, just west of Adrian, Minnesota (page 92), may be kames. The north-south alignment of the hills north of Little Rock might also be explained by assuming that they were built where a stream emerged from the ice, a position which successively changed as the front of the ice retreated.

The second hypothesis assumes that the gravels were deposited in channels, moulins or other cavities, on or in the ice. When the ice melted such masses were left on or in the upper part of the drift sheet, but might extend some distance into the drift or even be inclosed in the upper part. During the lowering of the mass, or during its transportation after formation, it might be tilted in the manner demanded by these hills. The chances of such deposits being formed were probably greatest near the edge of the glacier where the ice was thin, and where holes could extend even through it to the ground beneath. It would be relatively easy for masses of till to be incorporated in such deposits by falling from the walls of the channels directly into the accumulating gravel.

The third and fourth hypotheses listed differ only in the time of deposition of the gravel. Both are alike in so far as the method of plowing up the gravel and getting it into the Iowan till is concerned. 
The third makes the gravel of pre-Iowan age, the fourth of Iowan age, preceding possibly by only a short interval the time when it was plowed up by the advancing ice sheet. The evidence given above (page 100) is almost conclusive for an Iowan age.

The chief features demanded are that the gravel be of Iowan age; that it be deposited in an approximately horizontal position; that some of the masses be tilted to considerable angle and partly inclosed in Iowan till, but rising slightly above the general surface. Either the second hypothesis, calling for deposition within channels or moulins in the ice, or the fourth hypothesis, with deposition just beyond the front of the ice, will fulfill these conditions, since they differ only in the place of deposition of the gravel. It is probable that the conditions for the development of cross-bedding and lamination of the strata would be better met by deposition just beyond the edge of the ice, but conditions for the inclusion of large masses of till in the gravel are best met by deposition in moulins, from the walls of which the till might fall directly into the accumulating gravels. The writer believes that the majority of the material had its origin in moulins and channels in the ice, as outlined in the second hypothesis, but would not exclude the fourth hypothesis. In so far as the hills fulfill the conditions of true kames, the first hypothesis may be used. 


\section{CHAPTER III}

\section{THE KANSAN DRIFT REGION}

The Kansan drift region of northwestern Iowa is the area which lies west of the Iowan drift boundary. It includes all of Woodbury and Plymouth counties, most of Ida, Cherokee, Sioux and Lyon counties and small parts of Sac and O'Brien counties (Plate I). To the south it broadens out into the great Kansan drift region of southern Iowa and northern Missouri. Northward it continues into southwestern Minnesota and eastern South Dakota, occupying the narrow area between the Iowan drift region on the east and the Dakota lobe of the Wisconsin drift region on the west (figure 2). From the northwest corner of Iowa southward to Canton the Wisconsin drift plain lies just west of the Big Sioux valley. South of Canton the Kansan plain extends westward into southeastern South Dakota and northeastern Nebraska.

\section{TOPOGRAPHY \\ General Characteristics}

The topography of the Kansan drift region is erosional, and the greater part of the area is in the mature stage of the erosion cycle and presents a rolling or rough topography. The entire surface of the Kansan drift is well drained, being characterized by long, direct stream courses, which, for any particular locality, generally have a rather uniform direction but diverge enough to make a dendritic stream pattern. Long, gentle slopes lead down from either side, making a topography of broad, open valleys. Most of the divides are rounded without level upland areas and all the surface is in slopes. The lower parts of the valley slopes are broadly concave and their upper parts are broadly convex. It is the topography typical of maturity. The relief varies from place to place, being only 20 to 40 feet in some places and 125 to 150 feet in others. The steepness of the slopes varies with the relief.

The Kansan drift plain includes considerable range in both relief and degree of dissection. There are a few quite level or almost flat areas; there are areas with slight relief, with long, gentle slopes; areas of moderate relief, well drained; rolling and rough areas with steep 
slopes; and sharply dissected areas with very steep slopes. These various types of topography have an orderly arrangement with respect to the chief drainage lines and in most cases grade rather gradually from one type to another.

\section{Description of the Topography}

The most typical Kansan topography as judged by the standards of southern lowa is found in the southwest part of our region in Woodbury, Ida, southwestern Sac and western Plymouth counties. Here the relief is 100 to 150 feet and the region is rolling to rough, the typical Kansan of southern Iowa. To the east and northeast, with increasing distance from the great drainage lines, the relief and ruggedness decrease, with prongs of the more rugged topography extending northeast along the drainage lines and prongs of the more even type extending southwest along the interstream areas.

Most of the Kansan region of northwestern Iowa has a rolling topography with a relief of 50 to 100 feet. This type covers Lyon, Sioux, eastern Plymouth and western Cherokee counties. The drainage pattern is distinctly dendritic, the slopes are definite but of moderate steepness, and the region is well drained. This area includes the best farm land of northwestern Iowa.

At several places within this rolling Kansan drift region there are areas that have only slight relief. Several of the more prominent of these lie just outside the Iowan drift boundary and have been mentioned in connection with that subject. There are small areas of this type on the divide south of Odebolt in southwestern Sac county and on the divide around Holstein in northern Ida county. Parts of Marcus township of northwestern Cherokee county are only slightly rolling, and farther northward along this divide between Mill creek and Floyd river there is a considerable area of almost level surface in Caledonia and Baker townships of southwestern O'Brien county. Another quite level area lies in northern Sheridan township of Sioux county (page 65 ). These more level areas do not seem to represent the original Kansan plain as do the level uplands of southern Iowa, but the whole region seems rather to have been eroded beyond the mature stage of the cycle. It is this more even or slightly rolling type that exists along most of the Iowan boundary, and the Iowan drift region is apparently merely this slightly rolling Kansan type veneered by a thin layer of Iowan drift. 
Although erosional features are the dominant ones of the Kansan drift region, there is one region with a topography that is in part constructional. This is a belt five to ten miles wide just east of the Missouri river valley through Woodbury and southwestern Plymouth counties. The topography is of a bold rugged type, characterized by steep slopes which are at many places almost bare of vegetation, by pointed hills, and by narrow ridges (figure 16, page 117). This area has a thick deposit of loess and the topography is partly loess-formed. It continues southward along Missouri river through western Iowa and has its best development south of our region. Five to ten miles from the Missouri and Big Sioux river flats, with decrease in thickness of the loess, this topography grades into the more typical erosional topography of the Kansan drift region.

East of the region which has the distinctive loess topography, the loess is much more extensive as a thinner deposit, mantling the rounded profiles of the drift surface but not notably affecting the topography. This mantling loess deposit, thinning eastward, covers the entire Kansan area.

\section{THE KANSAN DRIFT}

\section{General Characteristics}

The Kansan till of northwestern Iowa consists of a clay matrix with numerous sand grains, pebbles and bowlders scattered through it. The matrix is finely ground rock-flour, gritty from the presence of very small sand grains, but somewhat plastic if moderately moist. At the surface and in exposures of moderate depth the till is oxidized and has a yellow or brownish yellow color. Below this is the unoxidized "blue clay" phase of the Kansan. The till is cut by numerous joint planes belonging to sets that intersect at such angles as to give the clay a very characteristic fracture into angular fragments a quarter to threequarters of an inch across. Both the oxidized and unoxidized phases are strongly calcareous, even up to the surface or up to the base of the overlying loess. Calcareous material is present further in the form of small grains, pebbles and cobbles of limestone, and, near the surface at many places, as small concretions and gray powdery material along joints.

The oxidized yellow clay at the surface and on the face of cuts is moderately loose, but a few inches beneath the surface it is compact and hard and if wet is tough and gummy. The oxidized yellow clay 
horizon has a usual thickness of 15 to 20 feet, with a range from zero to probably 40 feet. In general it is thicker in those parts having a more rugged topography and thinner in the more level regions. It is thicker on the hills than in the valleys, and in some of the marshy flats it is entirely absent and blue clay lies directly beneath the soil or alluvium.

Calcareous concretions one to two inches across exist in the upper part of the oxidized Kansan till in many of the exposures. They are not so large as those of the Nebraskan till but are larger than those commonly found in the loess. They are formed by the leaching of calcium carbonate from the till or the overlying loess and its concentration in nodules lower down. At a number of places these nodules have an elongate form and stand in a vertical position along the joint planes. They are more numerous and larger in the Kansan till south of our region, as exposed in the cuts of the Chicago, Milwaukee, St. Paul and Pacific railway in Carroll county.

In most exposures the blue clay is plastic and gummy and, if only recently exposed, is very tough and hard. When dry it has a light blue-black or bluish gray color on the face of the exposure, while just beneath the surface it is almost black and with greater depth grades into the typical blue clay. The blue clay is exposed in the banks or beds of many valleys where erosion is now active, and is penetrated by all wells of any great depth. Its thickness differs with the total thickness of the Kansan.

The blue clay is the fresh unoxidized phase of the Kansan till, and the yellow clay is the oxidized form. The transition from the blue to the yellow is, as a rule, abrupt or accomplished within a very thin transition zone, but the alteration to a yellow color may extend down into the blue clay along joint planes, affecting the clay for several inches from these planes. Where the till is much broken by intersecting joints and is mixed with irregular pockets and veins of sand which allow the weathering agents irregular access to the till, there is, at the contact, a zone several feet thick made up of masses of unoxidized till enclosed in oxidized till. Where the till is moist and where, because of recent erosion and exposure, rapid alteration is now in progress, a blue-black phase is present in the transition zone between the blue and brownish yellow phases.

Gray limestone is the dominant rock material among the pebbles of the Kansan till, forming more than 70 per cent of the total number of 
pebbles; Other types of limestones and a few quartzites and shale pebbles increase the number of sedimentary pebbles to about 75 per cent of the whole. The remaining 25 per cent consists of igneous pebbles, chiefly granites. The large cobbles and bowlders are dominantly igneous; quartzite, which is never abundant in the analyses of pebbles, is common; while limestone bowlders are rare. The pebbles of the Kansan drift are in most cases rounded or subangular, but a few are angular. The drift separates cleanly from the pebbles, and the white limestone pebbles show plainly against the darker clay.

\section{Source of Material for the Drift}

The bedrock of northwestern Iowa belongs to the Cretaceous system, which also is present in great thickness to the north. The dominant rock of this system is shale, and the remainder is largely shaly limestone and friable sandstone. Its most notable contribution to the drift was the material for the clay matrix, derived largely from the shale, but it also yielded much soft limestone which was ground to powder. Although they contributed the bulk of the drift material, the Cretaceous rocks are not common among the pebbles and never appear among the bowlders.

The compact gray limestone pebbles of the till are commonly unfossiliferous, but a few contain fragments of Ordovician fossils. No limestone of this age is known in the bedrock of northwestern Iowa or for several hundred miles to the north along the course followed by the ice, but in the northwest corner of Minnesota and extending northward along the valley of Red River of the North through Manitoba to Lake Winnipeg and beyond, there is a belt of Ordovician, Silurian and Devonian rocks which probably furnished the limestone pebbles of our region. The igneous pebbles and bowlders were derived from the pre-Cambrian rocks of Canada and northern Minnesota and from the smaller areas in the Red river and Minnesota river valleys. The large amount of calcareous material in the matrix of the drift was derived in part from the impure limestone and calcareous shale of the Cretaceous and in part from the Paleozoic formations that furnished the limestone pebbles.

In the extreme northwest corner of Iowa are a few outcrops of quartzite, and to the northwest around Sioux Falls there are considerable areas of this rock. It is very resistant and furnished many bowlders for the drift of northwestern Iowa. In decreasing abun- 
dance they occur southward to the limit of glaciation. The largest of these quartzite bowlders exposed at the surface in our region is "Pilot Rock" in the southeast quarter of section 15, Pilot township, Cherokee county, four miles south of Cherokee. Here is a great block of reddish quartzite about 35 feet by 25 feet and rising 10 to 15 feet above the surface.

Preceding the Kansan epoch, northwestern Iowa had been glaciated by the Nebraskan ice sheet, which deposited a thick sheet of till. As the Kansan ice sheet advanced over the surface of the Nebraskan till, it gathered up great quantities of the older till and mixed it with such new materials as it brought in, making the Kansan drift. It also picked up masses of Nebraskan till and incorporated them in the Kansan till without intimate mixing. There are also masses of gravel, sand and silt inclosed in the Kansan, and these probably were gathered in a similar way either from interglacial deposits resting on the Nebraskan or from outwash deposits laid down in front of the advancing Kansan ice sheet. These gravel masses and the evidence as to their age are considered on pages 111 to 115 .

\section{HISTORY OF THE KANSAN DRIFT REGION}

A' notable characteristic of the Kansan till of northwestern Iowa is the small amount of alteration and weathering which it shows. Oxidation to a yellow color commonly extends to a depth of 15 to 20 feet, and locally the till is iron stained along the joints, but the degree of this oxidation is only moderate. Excessive oxidation of the type represented by the iron-stained horizon (ferretto) present at the top of the Kansan till at many places farther south is lacking in northwestern Iowa. Further, the Kansan till of northwestern Iowa is commonly calcareous to the surface. In only a few places in the south and southwest part of the region was any leached till found. Even where the overlying loess is leached for its entire thickness, the till beneath is commonly unleached. . In southern Iowa leached till is commonly present and in many places has a depth of several feet.

In the Kansan drift region of southern Iowa the principal divides of a region commonly rise to a uniform altitude and have some level surface at their summits. These level areas are interpreted as remnants of the original Kansan drift plain, which is thought to have been relatively level without marked constructional features.

These level uplands of southern Iowa are covered with about 10 feet 
of gray to dark colored noncalcareous sticky clay which Doctor Kay has named gumbotil ${ }^{34}$ and interpreted to be the result, chiefly, of the chemical weathering of Kansan drift ${ }^{35}$ on the level Kansan drift plain. The characteristics and distribution of the Kansan gumbotil are fully treated in a report by Kay and Apfel in a recent volume of the Iowa Geological Survey. ${ }^{36}$ Beneath the gumbotil there is a zone of leached Kansan till about 5 feet thick. This leached zone grades upward into the gumbotil and downward into unleached till and represents a less altered phase of the till. After the development of the gumbotil zone an uplift is believed to have occurred, and erosion has carved out a mature topography and reduced most of the surface below the level of the former gumbotil plain. The above interpretation is based on the evidence of the remnants of this plain.

Remnants of the gumbotil zone are numerous in southern Iowa and continue northward to Carroll and Crawford counties, just south of our region. $^{37}$ The most northerly known exposure of the Kansan gumbotil is in a railway cut two miles east of Kiron, a few miles south of the southwest corner of Sac county.

Neither the level uplands nor the gumbotil have been found within our region, although exposures of unleached till have been seen on most of the high areas. However, it is believed that northwestern Iowa has passed through essentially the same history as has been outlined for southern Iowa by Kay. That is, that the Kansan ice sheet left a relatively even drift plain; that the gumbotil and the leached zone below were developed over the entire region; that the gumbotil plain was uplifted; and that it has since been eroded. This erosion, however, has been greater in northwestern Iowa than in southern Iowa, so that, although remnants of the plain and the gumbotil remain in southern Iowa, in northwestern Iowa all the surface has been reduced below the level of the gumbotil plain and every remnant of the plain, the gumbotil and the leached zone has been destroyed.

\footnotetext{
34 Ray, G. F., Gumbotil, a New Term in Pleistocene Geology : Science, Vol. XLIV, pp. 637-638, 1916. Also Iowa Geol. Survey, Vol. XXVI, pp. 216-218, 1917

35 Kay, G. F., Bul1. Geol. Soc. of Amer., Vol, 27, pp. 115-117, 1916. Also Iowa Geol. Survey, Vol. XXV, pp. 612-615, 1916

Kay, G, F., and Pearce, J. N., The Origin of Gumbotil: Jour. of Geol., Vol. XXVIII, pp. $89-125,1920$.

86 Kay, G. F., and Apfel, E. T. The Pre-Illinoian Pleistocene Geology of Iowa: Iowa Geol. Survey, Vol. XXXIV, Chapters VI and VII, 1929.

37 Kay, G. F., and Apfel, E. T., Iowa Geol. Survey, Vol. XXXIV, p. 129, Fig. 27, 1929.

Kay, G. F., Pleistocene Deposits between Manilla in Crawford County and Coon Rapids in Carroli County: Iowa Geol. Survey, Vol. XXVI, pp. 213 to $231,1917$.

Carroll Count : Iowa Geol. Survey, Vol. XXVI, pp. 213 to 231, 1917. Gol. XXXII, pp. 322, 323, 1927.
} 
Concerning this matter of erosion of the gumbotil plain in Carroll county just to the south of our area Kay wrote as follows : ${ }^{38}$

"The history of northern Carroll county and farther to the north seems to have differed from the history of the Templeton region (southern Carroll county) in having undergone still greater erosion. Northward from Templeton there are fewer and fewer remnants of the weathered zones until none are found. Moreover, in the region of Templeton there appears to have been more erosion than farther to the south. In southcentral Iowa the uneroded remnants of upland with gumbotil and leached drift are a somewhat distinctive feature of the topography."

The above explanation includes several points that have not been conclusively proved, but the interpretation explains the conditions fairly well. It has not been proved that the gumbotil plain extended over northwestern Iowa. However, the writer has seen a good deal of the evidence in southern Iowa and in Carroll and Crawford counties just south of our region, upon which Kay bases the gumbotil interpretation, and considers it so strong that he cannot fail to use this interpretation for the southern part of the region here under discussion. It is believed that the development of the gumbotil to a depth of 10 to 15 feet over southern Iowa required a very great length of time. Such thicknesses are found northward to Carroll county, where a section recorded by Kay from a railway cut three miles west of Templeton shows 15 feet of Kansan gumbotil. ${ }^{39}$ A deposit of this origin and representing such a great lapse of time could not terminate abruptly and, therefore, it seems very probable that the gumbotil was developed farther northward over northwestern Iowa during this same long interval of time.

The way in which the remnants of the gumbotil on the highest divides become fewer and smaller as they are traced northward in westcentral Iowa, and especially in Carroll county, indicates strongly that these remnants have been entirely destroyed farther north; that is, that northwestern Iowa has been entirely reduced below the level of the gumbotil plain. The unleached Kansan drift at the surface in northwestern Iowa is.similar in all respects to the unleached Kansan drift which exists beneath the leached drift and gumbotil farther south. The altitude of the remnants of the gumbotil along the divide between the Mississippi and Missouri rivers increases gradually northward from

38 Iowa Geol. Survey, Vol. XXVI, p. 218, 1917.

39 Iowa Geol. Survey, Vol. XXXIV, p. $226,1929$. 
about 1,200 feet at Tingley, near the south line of the state, to nearly 1,500 feet west of Templeton in Carroll county. ${ }^{40}$ If these altitudes are used to project the plain northward, it is found that it would pass above all the high points of northwestern Iowa.

An uplift of the region is postulated in order to allow the dissection of the gumbotil plain. In southern Iowa, where remnants of the gumbotil plain exist, the postulated uplift rests on firmer basis than in northwestern Iowa, where the uplift is merely inferred. The question as to why northwestern Iowa was eroded more deeply than southern Iowa, in spite of the fact that it is farther up the Missouri valley, has not been satisfactorily answered. Possibly the uplift in northwestern Iowa was greater than in southern Iowa; possibly it occurred earlier. There exist in northwestern Iowa considerable areas of slight relief which by this hypothesis must be interpreted as having been reduced below the original plain, and yet they are not at flood-plain level. The origin of these areas is not understood.

The writer has attempted in earlier manuscripts to develop an explanation of the unleached Kansan drift of northwestern Iowa as compared with the Kansan drift farther south on the basis of difference in the composition of the drift; difference in topography and relief, as affecting the rate of alterations; difference in rainfall and other climatic factors. None of these attempts has been satisfactory. The chief difficulty has been to explain the apparent abrupt dropping out of the gumbotil and leached zone horizons just south of our region. By all these interpretations these horizons should pass out gradually northward or grade into some other alteration product.

\section{GRAVEL AND SAND MASSES INCLUDED IN THE TILL General Characteristics}

There is in the till of northwestern Iowa a large quantity of gravel and sand in the form of inclosed masses (gravel bowlders). These are known in both the Kansan and Iowan drift regions and are apparently inclosed in both the Kansan and Iowan tills, although it is not possible in most cases to distinguish these tills. These gravel masses were observed in cuts and in the fresher. and steeper valley-side exposures. When they are penetrated by bored or drilled wells they are usually reported as gravel layers but in dug wells their true nature is

40 Iowa Geol. Survey, Vol. XXXIV, p. 261, 1929. Also Vol. XXVI, p. 229, 1917. 
revealed in most cases. Most wells which stop in gravel masses fail to furnish an adequate supply of water.

The gravel masses range in size from small pockets a few inches across to huge masses 10 to 20 feet or more in diameter. Common dimensions are three to six feet. A mass exposed in a railway cut in section 6 of Douglas township, Ida county, about $1 \frac{1}{2}$ miles south of Washta, is about 35 feet by 20 feet on the face of the cut and another in a Chicago \& North Western railway cut just east of Sioux Rapids is 20 to 25 feet across.

Most of the sand and gravel masses are roughly equidimensional or compressed in a vertical direction, but some are irregular in shape. Most of them have a rounded form, but several were seen with corners projecting into the till in such ways as could have been assumed only. when the gravel masses were frozen.

The sand and gravel of the bowlders are, as a rule, stratified. The beds range in position from approximately horizontal to vertical, and locally the layers are contorted. The bedding of a particular bowlder is usually a unit, but a few 'cases were observed which show faulting and some crushing, and in many cases the bedding is obliterated at the margins of the mass.

The material of these bowlders is sand, fine gravel, and some silts. Most of it is slightly ferruginous so that an iron-stained dust is released when the gravel is displaced. There are a few masses composed of strongly rusted gravel. In general the coarse gravel is rusted and partly decomposed, while the finer material is fresh and unaltered. The coarse-grained igneous pebbles are more decomposed than the finergrained ones and the darker colored varieties (containing mica and hornblende) more than the lighter colored. Most limestone pebbles are altered slightly at the surface and a few are altered to the center or decomposed to clay ironstones.

Seventeen analyses of gravel associated with till were made, but there is some question concerning the correct interpretation of a number of these as gravel bowlders. The analyses of the ten positive cases average 38 per cent igneous and 62 per cent sedimentary rocks, 50 per cent being limestone. The average for the seventeen analyses is 41 per cent igneous rocks and 59 per cent sedimentary. Small rounded balls of till (clay-balls) were seen in a few of the gravel bowlders.

In most cases the till is fresh up to the edge of the gravel bowlder, but in a few cases a thin shell, concentric with the border, is stained, 
altered, and partly cemented with ferruginous material. Also in a few cases the gravel is cemented in a shell around the outside of the mass. This alteration and cementation is a contact phenomenon which has been produced since the inclusion of the gravel mass.

\section{Description of Some Typical Gravel Masses}

Little Sioux river valley across northern Buena Vista and southern Clay counties has been cut deeply into the till, and both natural and artificial exposures along the valley show many gravel bowlders. This is in the Iowan drift region, but an Iowan drift cannot commonly be differentiated from the Kansan, and the till of these bluffs is quite certainly Kansan. A large sand bowlder in a cut of the Chicago and North Western railway just east of Sioux Rapids has been noted above (page 112), and gravel masses are numerous in several cuts a little farther east. In the southeast quarter of section 3, Barnes township, Buena Vista county, just east of where the railway crosses the terrace area, is a cut which, although old and slumped, showed a great number of sand bowlders.

Near the top of the bluff north of the schoolhouse at Peterson there is a pit excavation 30 to 40 feet across and 15- to 20 feet deep. The material excavated was supplied by several large sand and gravel bowlders packed closely together. Some of the vertical contacts with the inclosing till were exposed. Some of the material is coarse gravel, some is fine sand, and some is silt. The material is stratified, and the beds now stand at various angles. Near the top of the slope leading to the upland southwest of Peterson the road cut exposed a lens of sand 50 feet long and 10 . feet thick. The material is slightly iron-stained and around the edges of the mass is somewhat contorted.

- A large sand bowlder was exposed in a road cut on the slope toward the river in the north half of section 26, Waterman township, O'Brien county, and at about the center of section 14 of the same township the east bluff of Waterman creek showed several gravel bowlders, 4 to 10 feet across, inclosed in Kansan till.

Just east of the center of section 22, Brooke township, Buena Vista county, the west bank of a ravine exposed an old-looking ferruginous sand and gravel with some fine silty layers. The exposure had a length of about 50 feet and rose 40 feet above the ravine bed to the top of the slope. In either direction the ravine slope was grassed over and the basal part of the exposure was too badly slumped to show material in place, but Kansan till was exposed in the ravine bed just south of the exposure and rose 6 to 8 feet above the ravine bed just north of the exposure. There is little doubt that this is a great gravel mass included in the Kansan till. The bedding of the mass dips slightly to the south and apparently back into 
the bank to the west. Ferruginous concretionary cementation has affected part of the sand and has formed irregular shaped masses, some of which are more than a foot across. The material composing this mass is much more decomposed and altered than is common for the gravel masses.

In the north bluff of Storm lake, near the center of section 4, Hayes township, Buena Vista county, there are several irregular masses of loesslike silt and sand. At several places the layers making up the masses are contorted and crumpled and even broken off, so that they abut against other parts of the mass in which the layers have a different angle.

In the north part of Cherokee, in an alley just east of Second street and south of Spruce street, a bank showed a large mass of silt and sand partly inclosed in till. The material is somewhat contorted and the layers are in part steeply inclined. This exposure is probably of Iowan drift. A series of road cuts in Kansan till in the northeast quarter of section 28, Cherokee township, showed in 1916 a large number of inclosed gravel masses. The face of one of these cuts near the north line of the section showed almost as much gravel as till.

Other gravel masses were seen in the south bluff of Mill creek between the bridges in the northeast quarter of section 23, Cherokee township; in the bluffs of the creek valley of section 24 , Cedar township; along the creek valley through sections 11 and 10 , Pilot township, south of Cherokee; and at many other places throughout the area. In fact, most large exposures of till show some of these gravel masses. Most of the gravel masses so far described are in the Iowan drift region, but the Iowan drift is believed to be very thin and the gravel masses are apparently in the Kansan till.

In the south bank of a ravine in the south part of section 10 , Stockholm township, Crawford county, about a quarter of a mile west of the railwáy there are several gravel bowlders four to ten feet in diameter and some smaller ones of sandy silt or silt. The material of these gravel bowlders is somewhat iron-stained and in one case the gravel around the border is partly cemented, while in another the surrounding clay is iron-stained for two to three inches, concentric with the border of the bowlder. An analysis of pebbles from one of these bowlders gave 30 per cent igneous rocks and 70 per cent sedimentary rocks, 7 per cent of which were clay-balls. The layers of the gravel composing the bowlders are inclined.

In the south bank of the road cut just east of the railway crossing in the east part of section 15, east of Sioux Falls, South Dakota, there is a mass of gravel completely inclosed in the Kansan till. The gravel is rather fresh and contains shale pebbles and drift pebbles. The analyses showed 49 per cent igneous rocks and 51 per cent sedimentary. The bedding of the mass is inclined. 
Masses of gravel inclosed in Kansan and Nebraskan till are present at many places in western and southern lowa south of our region. Great masses of gravel, formerly interpreted as Aftonian gravels, in . Union county in southern Iowa and in Harrison and Monona counties in western Iowa, have been recently interpreted by Kay as lenses and irregularly shaped masses inclosed within the till. ${ }^{41}$

\section{The Origin of the Sand and Gravel Bowlders}

The presence of the rounded, rectangular or angular masses of stratified gravel, sand and silt completely inclosed in the till has been noted. It has also been noted that some of these gravel masses have angular corners projecting into the till and that the layers of the masses have various positions. These points indicate that the gravel masses are fragments of larger deposits which were broken up, probably while they were in a frozen condition, and the fragments were incorporated like rock bowlders in the till. As to the origin and age of the gravel deposit that was thus broken up, two hypotheses may be considered. (1) It was an interglacial deposit which existed in the region prior to the Kansan or Iowan ice epoch. (2) It was an outwash deposit laid down in front of the advancing Kansan or lowan ice sheet, which a little later plowed it up.

An interglacial deposit should consist largely of well worn pebbles of the harder, more resistant types of rock that are left after the weaker ones have been worn out or decomposed. It would commonly consist of leached material. By both of these criteria the gravel of these masses does not seem to be interglacial.

In general appearance and freshness the pebbles of the gravel masses bear a close resemblance to pebbles picked directly from the Kansan or Iowan till. The clay-ball pebbles which are present in the gravel show that the material was not transported far before its deposition. 'These clay-balls are of Kansan or Iowan till.

The gravel masses are, therefore, considered to be contemporaneous with the till sheet which incloses them and the gravel is interpreted as having been deposited beyond the front of the advancing ice sheet, which a little later plowed it up and incorporated fragments of the frozen mass in its drift. Deposition in openings beneath the ice or low enough in the ice to become inclosed in the till would also suffice.

41 Iowa Geol. Survey, Vol. XXXIV, pp. 184-195. 


\section{CHAPTER IV}

\section{THE LOESS}

\section{General Characteristics and Distribution}

The Kansan and Iowan drift regions of northwestern Iowa are covered with a mantle of fine-grained yellow clay known as loess. In the southwestern part of the area the loess has a considerable thickness, but it thins to the northeast until it is almost negligible. It crosses from the Kansan region east onto the Iowan area and continues to the Wisconsin boundary. In the regions where the loess is thick, it is commonly calcareous to the surface and in many exposures contains calcareous concretions and snail shells. Farther northeast, where the surface is more even and the loess is thinner, it is leached in its upper part, or possibly for its entire thickness, and shells and calcareous concretions are absent.

\section{The Region of Thick Loess}

The region within which the loess covering is thick includes Woodbury county, Ida county except the northeast part, the southwest part of Sac county, and a belt along the east side of the Big Sioux valley narrowing northward through western Plymouth, Sioux and Lyon counties. Within this area many road cuts on the slopes or on the crests of the hills expose 10 to 20 feet of loess. It is buff to yellow in color, commonly calcareous to the surface, contains concretions at many places, and in some places is fossiliferous with snail shells. In the more recent road cuts the loess stands as cliffs.

The greatest thickness of the loess is found in a rugged belt five to ten miles wide just east of the Missouri river valley in Woodbury and southwestern Plymouth counties. Here exposures of 30 to 50 feet or more of loess exist. The topography is rugged, made up of narrow ridges and pointed hills (figure 16). The slopes are steep and at many places almost bare of vegetation. The more prominent characteristics of this topography and much of the relief were produced by the deposition of the loess. The elevations of the hilltops of this belt are, in general, greater than in the region to the east. It is an area of distinc- 


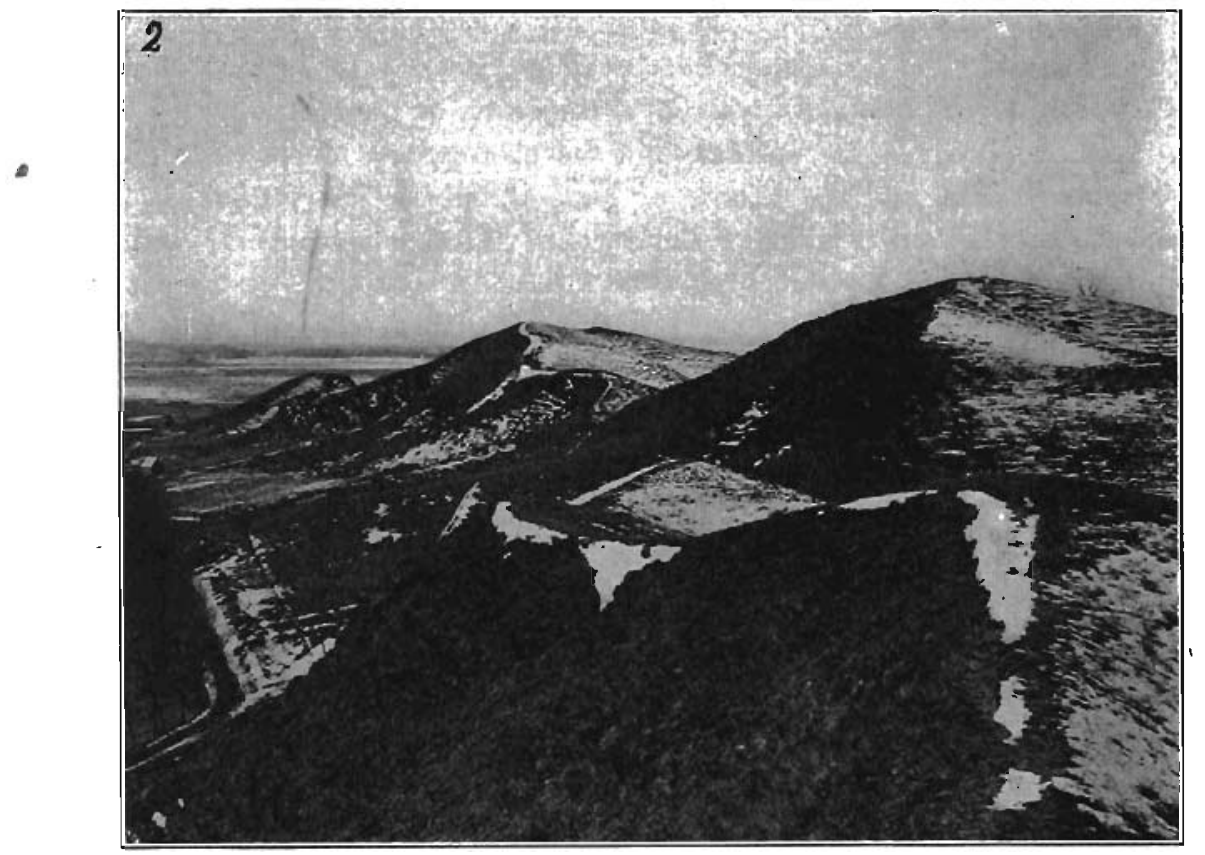

FIG. 16.-The topography of the loess-covered region north of Turin, Monona county. Snow partly covers the surface, especially to the lee, east, of the crests. (Shimek, Iowa Geological Survey, volume XX, p. 289.)

tively loess-formed topography which continues southward along Missouri river across western Iowa.

\section{The Northeast Border of the Thick Loess}

Along a belt on the northeast, the loess thins abruptly within a distance of a mile or less, so that there appears to be a loess boundary. This belt, within which the loess becomes so much thininer, leaves the Wisconsin drift boundary near the south line of Sac county and extends northwest across southwestern Sac, northeastern Ida, southwestern Cherokee and southeastern Plymouth counties. West of the Floyd river valley it extends west of north through western Plymouth, Sioux and Lyon counties. The change is more abrupt in Sac and Ida counties than farther northwest and more abrupt where this belt follows valleys than where it crosses upland country. In some places it seems to be a definite boundary, but on the whole it is simply a zone within which the thinning of the loess is very marked.

The zone within which the loess thins so notably is quite definite south of Wall Lake in Sac county through sections 33, 32 and 30 of Viola 
township and sections 25 and 24 of Levey township. This is along the Iowan boundary. To the southwest is rough, Kansan topography with a relief of 50 to 100 feet and road cuts at the crests of the hills show 10 feet or more of loess. To the northeast the Iowan region is much less rugged, the relief is less, and the mantle of loess is only a few feet thick. A marked contrast exists along a small valley through sections 33 and 32 of Clinton township, northwest of Wall Lake. In section 32 on the southwest of this valley the topography is rugged with a relief of 75 to 100 feet, with very steep slopes and sharp crests, and the road cuts through these crests expose 15 to 20 feet of loess without reaching its base. Across the valley in section 33 , the general altitude is 30 to 50 feet lower, the surface is moderately rolling, and loess is not prominent. A similar contrast exists along the Boyer valley in sections 34 of Clinton and 2 of Levey townships. In both of these cases the Iowan drift boundary is also the boundary of the thick loess.

Northwest of Odebolt, toward Maple river, there are several places where the border of the thicker loess is definite, but it is not a continuous boundary. The loess is thickest on the higher points and there is commonly some group of hills or a divide where the thicker loess projects farther northeast than is general, and along the northeast base of these hills the marked change is located. The first course of this type northwest of Odebolt is along the northeast base of a belt of hills in sections 21,20 and 18, Richland township. The base of this ridge at its east end is the Iowan boundary, but the boundary thence runs on north and toes not continue along the northeast face of the ridge. This belt of loess-covered hills continues on west through Blain township, Ida county, as the divide between Odebolt and Elk creeks. Some hills with thick loess, however, exist on the divide north of Elk creek in the southwest corner of Silver Creek township and in southeastern Logan township in the angle between Buffalo creek and Maple river, where a very marked contrast exists for a short distance.

A very marked contrast exists along the course of Maple river valley from section 25 of Logan township, Ida county, north to section 22 of Galva township. Rugged topography with deep loess cuts exists to the west of the valley, while to the east it is less rugged and there are few exposures of loess.

At the south end of the Iowan drift region southeast of Odebolt there is a close co-ordination between the Iowan boundary and the edge of the thick loess deposit and it appears that the thick loess was deposited while the Iowan ice sheet protected the area on the northeast. 
Northwest of Odebolt through northeastern Ida county these boundaries are not the same, the Iowan boundary as mapped being east of the edge of the thick loess. At Galva the Iowan boundary comes to the east side of Maple river valley, while thick loess covers the region west of the river. North of Galva there is no further relation between the two boundaries. The Iowan boundary runs north-northwest across Cherokee and O'Brien counties. The edge of the thick loess runs west-northwest across northern Ida, southwestern Cherokee and southern Plymouth counties. Westward the transition belt becomes broader and less definite and can hardly be considered a boundary.

At a number of places along the north-south valleys more rugged topography exists and the loess is thicker on the west slope than on the east. This feature is present in the case of several of the parallel valleys and is not a characteristic simply of the belt within which the loess becomes thinner but of the region of thick loess. This feature is shown along the West Floyd and other valleys of west central Plymouth county.

\section{The Region with Loess of Medium Thickness}

Over eastern Plymouth, western Cherokee, most of Sioux and western Lyon counties the Kansan drift region is rolling and the loess has a moderate thickness of five to fifteen feet. The relief varies from place to place, in general becoming more even to the north and the east. The preloess topography was rolling with similar features and relief 'and the deposition of the loess had little effect upon the topography. It is a loess-mantled topography. Roadside exposures of the loess are numerous along graded roads, the loess being commonly thicker on the slopes than on the crests of the ridges. On the more level surfaces the loess is leached for one to three feet, but on the steeper slopes where erosion is active it is commonly calcareous to the surface.

\section{The Region of Thin Loess}

The loess continues to thin to the east and northeast, decreasing to a mantle of two to five feet. This condition exists over the eastern part of the Kansan drift region in central Cherokee, southwestern O'Brien, eastern Sioux and eastern Lyon counties and over all of the Iowan drift region east to the Wisconsin boundary. Most of this region is quite even, and exposures over the uplands are few and shal- 
low. The natural exposures, being on the lower slopes of the valleys, do not commonly show the loess, which has been removed from such positions, and one must depend largely on artificial exposures on the level surfaces for data as to its thickness.

Within this region the loess is leached in its upper part and at many places for its entire thickness, where this is less than five feet. Where the loess is thicker than four to five feet, the basal part is unleached. The underlying till is commonly unleached even where the loess is entirely leached. The contact of the loess and the till is commonly definite.

In Clay, O'Brien, southwestern Dickinson, and southeastern Osceola counties the loess is only two to three feet thick and the surface is very level. When it is less than $2 \mathrm{r} / 2$ feet thick this mantle is commonly not definite loess but a loesslike clay which may contain sand grains and pebbles throughout. When traced from the southwest it is very evident that this is the continuation of the loess mantle.

The very definite and characteristic loess of the southwestern counties of our area has been recognized as loess from the earliest geologic work done in the region. This includes the area of thick loess and that with a mantle of five to fifteen feet. The material which overlies the Iowan region and the eastern edge of the Kansan region north of Cherokee county, and which is commonly leached for its entire thickness, has not previously been definitely recognized as loess. It was called loesslike clay or loam by the writer through much of the progress of the field work, and its identity with the loess to the southwest was not demonstrated until the summer of 1916, when a series of east-west tracings were made across the entire loess-covered region with a very careful study of the changes in the loess along these lines.

In the region of thicker loess the yellow calcareous, concretion-bearing, fossiliferous loess is seen at many places. In the region of thinner loess there are few exposures and these show the noncalcareous, brownish yellow pebbleless loesslike clay. But within the region of positive loess there are some exposures in which the upper part of the loess is leached and certain level areas where the leached loess is general, and in these places the leached loess is identical with the loesslike clay (leached loess) farther northeast. Scores of exposures were studied by the writer as he passed back and forth from the region of thick loess to that of thin loess and in this way the identity of the loess 
of the entire region was established. The loesslike clay of the thinly veneered areas is identical in origin with the distinctive loess of more deeply covered areas.

\section{Pebbles Within and on the Surface of the Loess}

In the region of thin loess and to a large extent elsewhere a few pebbles may be found within the loess, especially in its basal part. Their distribution is of two types: (1) Pebble bands bedded in the loess, and (2) occasional pebbles scattered through the loess. Those of the first class are restricted to the basal 12 to 18 inches of the deposit and are found where the loess overlies gravel in the valleys, or on the lower slopes of the hills where the loess accumulated on a topography of some relief. In the case of the occasional pebbles scattered through the loess they are found in large part where the entire thickness of the loess is not more than three feet. It was found that many of these pebbles could be shown to occupy old burrows of animals, and in many cases where the burrow was not at first apparent a careful examination revealed it. Not every pebble found in the loess was proved to be in a burrow, but a large percentage of them was found to be so located and probably practically all have had such an origin. The burrows go from three to five feet beneath the surface and at some places are quite numerous. In some cases where the burrows passed through the loess into gravel below, the burrows appeared like tubes of pebbles in the loess. Where the loess is more than four feet thick few of the burrows go through the loess and there is no opportunity for obtaining the pebbles.

In almost any part of the loess-covered area it is possible to find a few pebbles on the surface or in the loess soil. They may be found along the public roads and less frequently in the fields. Careful search along the road enabled the writer to find one or more pebbles along practically every quarter of a mile of road where the search was made within the loess area. There are several ways by which these pebbles may have come to their present location. Where the loess is thin they may be brought up by burrowing animals from the drift beneath the loess. Many of the pebbles along the roads have dropped from the loads of gravel being hauled along these roads. The pebbles in the fields may come with maniure hauled from barn lots, most of which have gravel in them. Others may have been carried from neighboring valleys in the mud attached to wheels, or to the feet of animals of his- 
toric or prehistoric times. It may be noted that during a search for pebbles, especially along the roads, one also finds nails, pieces of coal, cinders, iron, glass and crockery, bottle caps, bases of shot gun shells, etc. All these things have come to their present location by accident and were not derived from the loess beneath and likewise the few pebbles are believed to have come by accident to their position on the surface of the loess and not from within the loess.

Over much of the loess-covered region the loess does not completely cover the surface but exists where conditions were more favorable for accumulation or where erosion has been slight. The mantle of loess completely conceals the till where the surface is level or only slightly rolling, but on steep slopes the till is commonly exposed because erosion has removed the loess. The east and north slopes of hills have a thicker loess mantle than the opposite slopes or the crests of the hills, which is explained by the prevailing west and southwest winds and by the greater accumulation of the loess in the lee of the hills. Till is exposed at the crests or on the upper slopes of many hills which farther down the slopes have a complete loess covering. Under these conditions pebbles from the drift near the crest of the hill are washed down the slope onto the loess. Many examples of this condition were observed, where in ascending a loess-covered slope occasional pebbles were found and at the top of the slope the drift is exposed. It is not possible in all cases to show that the loess rests on the till, but it is possible to do this at many places. An example of this was found west of LeMars in Plymouth county west of West Floyd river on the south line of section 12, Washington township. Cuts in the lower slope show six to eight feet of loess without exposing the till but occasional pebbles are found on the road and in the gutters. Toward the crest of the hill just west of the southwest corner of section 12 the loess thins out and the till rises to the surface.

Another excellent exposure showing the relation of the till and the loess was seen in a road cut about 50 yards north of the southwest corner of the section 12 noted above. The cut extends north-south and is at the crest of a slope leading down to a valley to the north. At the crest of the hill the Kansan till rises five feet above the base of the cut and is overlain by six feet of brownish pebbly leached material (figure 17). In either direction from the crest the upper contact of the Kansan dips steeply and passes below the road grade, and the 
brownish leached zone thins to one foot and becomes an old soil. There is no true loess in the section at the crest of the hill, but below the crest in either direction it is present above the leached material and it

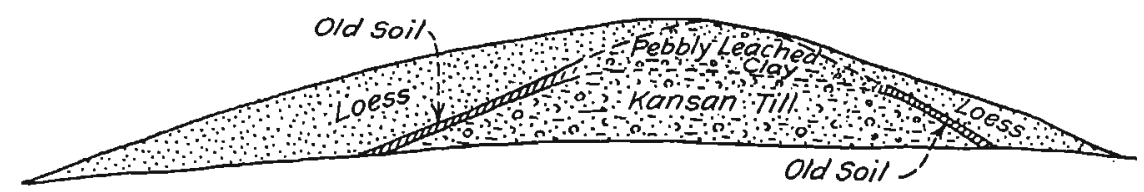

FIG. 17.-Sketch of a road cut exposure 50 yards north of the southwest corner of section 12, Washington township, Plymouth county. The sketch shows the relation of the loess to the pebbly leached clay at the top of a preloess hill, and to an old soil on the slopes of this hill.

thickens notably down the slopes, especially on the north slope, where it attains a thickness of at least 10 feet. Pebbles may be found lying on the loess on the lower slopes of the hill and no doubt they were washed down from the leached pebbly material exposed at the crest of the hill. If this were a shallow cut it would be like scores of others which were seen but in which the source of the pebbles was not so evident.

The most indefinite part of the loess mantle is commonly found near the crests of the hills where the mantle is thin. It cannot in all cases be so definitely related to the till as in the exposure just described, for if the cut is shallow, the relation of the till to the loess is not evident, and the till may appear to be above the loess which covers the slope lower down. In all cases, however, where an adequate cut exists it is evident that the sandy, pebbly material passes below the loess. This material at the crests may be distinctly different from the loess, as in the cut described above, or it may differ from the loess only in the presence of a few pebbles. In the former case it has been derived from the till, while in the latter case the bringing in of a few pebbles by burrowing animals or other means would suffice to explain the difference.

\section{Data Concerning the Nature and Thickness of the Loess}

A great number of exposures showing the loess were studied and a few of the better sections, most of which are artificial exposures, will be recorded. They are described in order from east to west along certain lines extending from the Wisconsin boundary westward across the Iowan and Kansan regions. This arrangement is followed in order to bring out the changes in thickness and nature of the loess along these lines. 
From Wall Lake West across Southern Sac and Ida Counties.-At the town of Wall Lake in southern Sac county, a basement excavation just north of the water tank showed the following:

FEeT

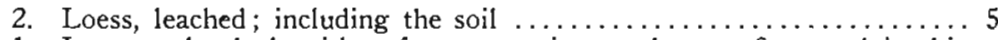

1. Loess, unleached, with a few concretions and some fine sand in thin

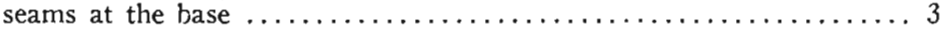

Wall Lake is less than two miles from the Wisconsin boundary, yet this material is unquestionably loess.

At the town of Odebolt, in southwestern Sac county, a basement excavation in the southwest part of town exposed the following:

3. Loess, leached, and soil $\ldots \ldots \ldots \ldots \ldots \ldots \ldots \ldots \ldots \ldots \ldots \ldots \ldots$

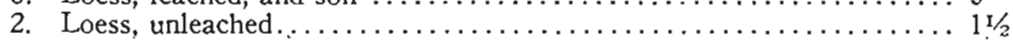

1. Till, yellow $\ldots \ldots \ldots \ldots \ldots \ldots \ldots \ldots \ldots \ldots \ldots \ldots \ldots \ldots \ldots \ldots \ldots \ldots$

Another excavation one square farther south showed:

FEET

2. Loess, leached, and soil $\ldots \ldots \ldots \ldots \ldots \ldots \ldots \ldots \ldots \ldots \ldots \ldots \ldots \ldots \ldots \ldots \ldots \ldots \ldots$

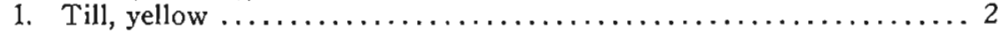

A trench on the main street in the east part of town exposed:

FEeT

2. Loess, leached $\ldots \ldots \ldots \ldots \ldots \ldots \ldots \ldots \ldots \ldots \ldots \ldots \ldots \ldots \ldots \ldots$

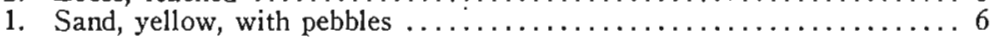

The trench exposure was open for 150 feet and showed no changes laterally.

These exposures at Odebolt are just within the boundary of the Iowan drift region and the till beneath the loess may be Iowan till but it is not possible to differentiate it from the Kansan till.

Five and a half miles south of Odebolt, near the quarter-corner on the west of section 26, Wheeler township, a gravel pit in Porter creek valley showed the following:

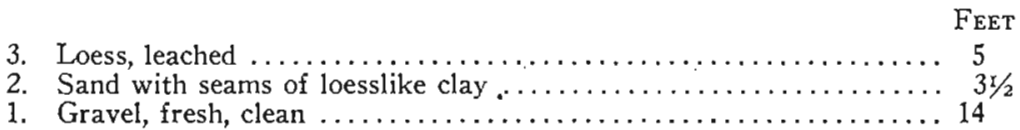

In another part of the exposure the loess is seven feet thick and is leached to a depth of only two feet. This is typical calcareous loess, containing concretions and a few small snail shells. This exposure is five miles beyond the Iowan boundary, out in the rugged Kansan region, but the loess material is the same as that at Odebolt and Wall Lake. The valley in which these gravels are located continues southward to Boyer river at Boyer, in Crawford county, and in its lower course gravel material overlain by fossilbearing, calcareous loess is exposed in several railway and other cuts.

At Arthur, in eastern Ida county, a basement excavation in the north 
part of town showed $4 \frac{1}{2}$ feet of leached loess to the base of the opening. Arthur is three miles beyond the Iowan boundary in the region of unquestioned Kansan drift and loess, yet this leached loess is identical withthat found farther east at Odebolt and Wall Lake. The loess thickens to the west across southern Ida and Woodbury counties and is exposed in many road cuts. In many of the exposures on the slopes where erosion is active the unleached concretion-bearing loess comes to the surface.

From Early West across Northern Sac and Ida Counties.-At Early in west-central Sac county an excavation at the schoolhouse in the northwest part of town showed the following:

2. Loess, leached $\ldots \ldots \ldots \ldots \ldots \ldots \ldots \ldots \ldots \ldots \ldots \ldots \ldots \ldots \ldots \ldots$

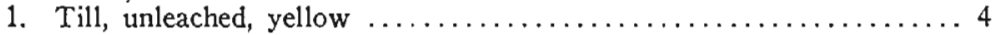

Early is less than two miles from the Wisconsin boundary, and exposures along the road leading north from Early show that the leached loess, about three feet thick, continues to the edge of the Wisconsin drift.

About five miles northwest of Early a railway cut at the southwest corner of section 28, Eden township, showed the following:

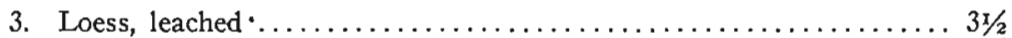

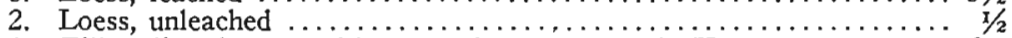

1. Till, yellow-brown, with concretions; apparently Kansan .......... 6

At Schaller in northwestern Sac county the following section was measured :

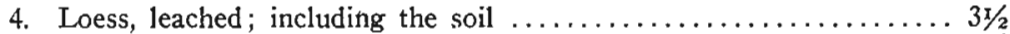

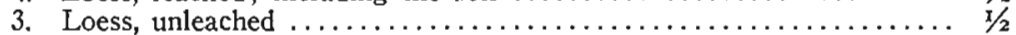

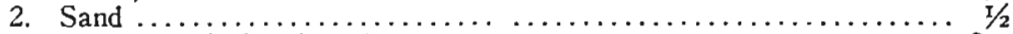

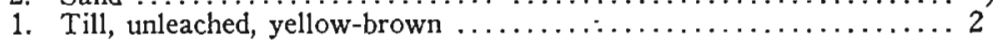

At Galva in northeastern Ida county a trench in the road in the south part of town showed the following:

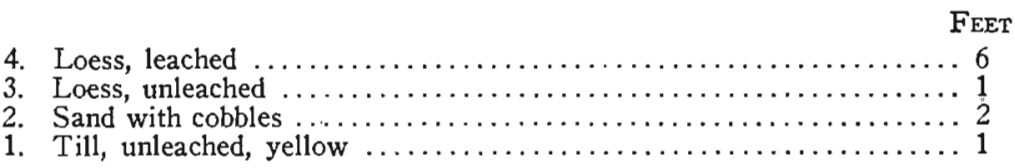

Another exposure in the east part of town showed leached loess to the bottom of a trench four feet deep.

These exposures at Early, Schaller and Galva are within the Iowan drift region and show the loess with thicknesses ranging from three to sevezz feet resting upon till which should be Iowan, but which could not be positively differentiated from Kansan in any of the exposures.

West of the Maple valley at Galva is the unquestioned loess region and the unleached loess is exposed in many road cuts. Near the northwest 
corner of section 27, Galva township, on the west slope of the Maple river valley, a highway cut exposed, in 1927, the following section.

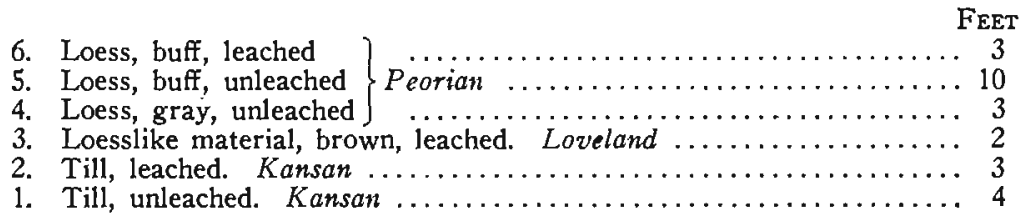

This is a very interesting exposure in that it shows a leached zone at the top of the Kansan, and the overlying leached, loesslike material, interpreted as Loveland, below the unleached base of the Peorian loess. Exposures of this type are more usual in the typical Kansan region of western Iowa farther south, but this is the most northern known exposure of this type in northwestern Iowa.

At Holstein in north-central Ida county a trench exposure on the street showed the following:

3. Loess, unleached, yellow-brown, mottled, with a few concretions $4 \mathrm{~L} / 2$

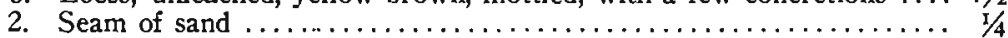

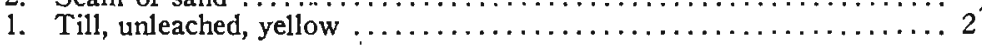

The divide cut on the railway one mile east of Holstein exposed the following :

3. Loess, leached $\ldots \ldots \ldots \ldots \ldots \ldots \ldots$

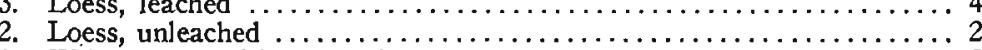

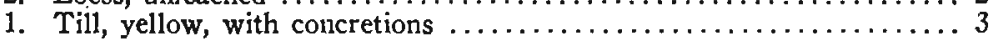

This series of exposures from Early through Schaller and Galva to Holstein extends from the Wisconsin boundary across the Iowan area into the unquestioned loess-covered Kansan. The loess is thicker to the west, and with this increased thickness the unleached zone appears, but the leached loess is the same at all places. Within a short distance west of Holstein the country is rugged and loess exposures are common in the road cuts. The loess thickens to the west across Woodbury county to Sioux City, where loess exposures 30 to 50 feet deep may be seen.

From Siorm Lake across Buena Vista, Cherokee and Plymouth Counties.-At Storm Lake a basement excavation on the main street showed the following:

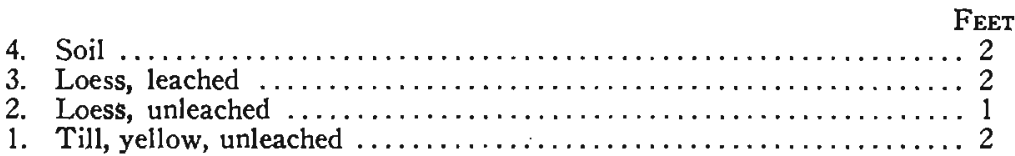

This exposure is within one mile of the Wisconsin boundary and in other exposures in the east part of town the loess may be found to, and possibly beneath, the Wisconsin drift. 
At Alta excavations along the railway just west of the station and in the divide cut in the west part of town showed three feet of leached loess with soil overlying unleached grayish yellow till with some concretions. This is at the crest of the great divide. The till exposed here and at Storm Lake is the light yellow till phase that is interpreted as Iowan.

In southwestern Buena Vista county, in the southwest quarter of section 21, Maple River township, a well boring passed through five feet of loess, and at the time of the writer's visit the well had been sunk to a depth of 50 feet, all in yellow till. This is an exceptional thickness for the oxidized zone of the till. This locality is within the Iowan drift region, but most of this thickness probably is Kansan till.

Just east of the Little Sioux east of Cherokee along the south line of sections 25 and 30 there are a number of cuts which exposed four to six feet of loess, and in at least two cases about a foot of unleached loess containing concretions was shown beneath the leached material. The first cut east of the southwest corner of section 30, Afton township, showed at the center till overlain by two to three feet of dark loesslike clay which contains some pebbles. In either direction down the slope this material becomes thicker and grades into typical loess without pebbles. An exposure on the south side of the road east of a ravine on the north line of the northeast quarter of section 36, Cherokee township, showed a mantle of about three feet of leached loess resting directly on the unleached till. At the contact are several gravel masses partly inclosed in the till and overlain by the loess. These are included gravel masses in the till which were exposed at the surface at the time the mantle of loess was deposited.

At Cherokee, at the new hospital in the north part of town, about 50 yards northwest of the building, a trench showed the following:

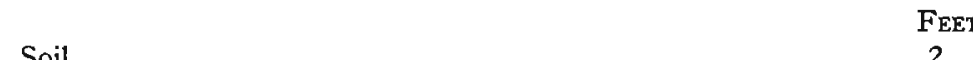

4.

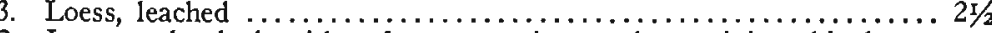

2. Loess, unleached, with a few concretions and containing thin layers

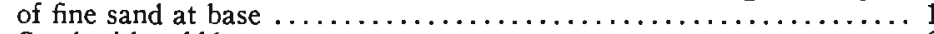

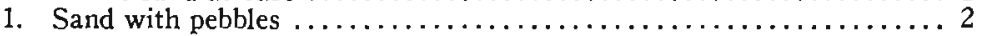

This exposure is on the high gravel bench of the Little Sioux valley, about 125 feet above the river. The position of the loess over the sand and gravel of the bench area shows that the gravel deposit of the high benches is older than the loess. A cut on Spruce street in the north part of town just east of Second street shows three feet of loesslike material overlying the gravel. The upper two feet of the zone is leached.

In 1916 a road in the northeast part of section 28, Cherokee township, had been recently graded and showed a number of good sections. The first cut north of the Cherokee water tank showed the following: 


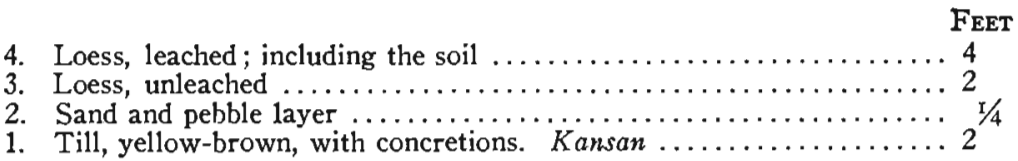

The third cut north of the water tank, at a bend of the road, showed the following :

5.

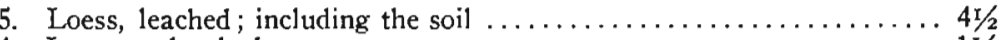

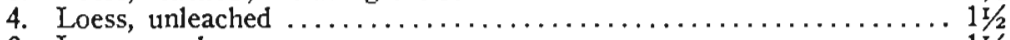

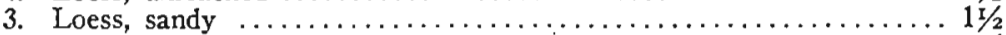

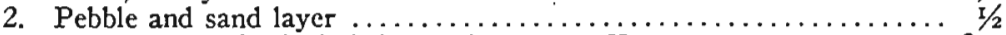

1. Till, yellow, with included gravel masses. Kansan $\ldots \ldots \ldots \ldots \ldots \ldots . \ldots \ldots \ldots 2^{2}$

In the loess zone of this exposure a section of a small elephant tusk about six inches long was found. Other cuts northwest to the viaduct across the spur of the railway show similar exposures. The first road cut east of this viaduct showed:

3. Loess, leached

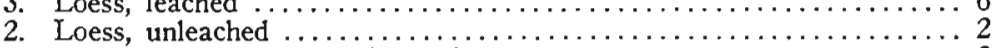

1. Sandy material, fine-grained, clayey $\ldots \ldots \ldots \ldots \ldots \ldots \ldots \ldots \ldots \ldots \ldots \ldots$

A railway spur in the southeast quarter of section 21 and the north part of section 28, on the grounds of the Cherokee State Asylum, showed in 1916 some newly made cuts. At the edge of the creek valley in the southeast quarter of section 21 the cuts showed 30 feet of typical brownish yellow Kansan till with large included sand and gravel masses. A thin zone of leached loess was exposed at the top of the cut.

The largest cut along this spur is at and just south of the north line of section 28. The Kansan till rises 15 to 20 feet in the cut and has included in it as lenses much material that is not typical Kansan. Just south of the section line there are several masses of Nebraskan till included in the Kansan. One of these, an elongate lens, is more than 50 yards long and six to eight feet thick and is somewhat mixed with yellow Kansan till. Another smaller mass consists of leached Nebraskan till. The upper contact of the till in this cut shows some small relief features not expressed in the present topography; that is, certain small irregularities in the till surface were filled in and obliterated by the sand and loess.

At one place in this cut a section exposed by cleaning a strip down the face of the cut was as follows:

9. Loess, leached; including the soil $\ldots \ldots \ldots \ldots \ldots \ldots \ldots \ldots \ldots \ldots$

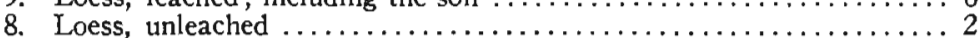

7. Loess and fine sand in alternating layers $\ldots \ldots \ldots \ldots \ldots \ldots \ldots \ldots \ldots$

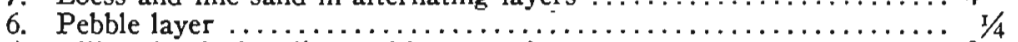

5. Till, unleached, yellow, with concretions $\ldots \ldots \ldots \ldots \ldots \ldots \ldots \ldots$

4. Till, unleached, blue-gray, pebbly, with a few concretions $\ldots \ldots \ldots \ldots 2$ 


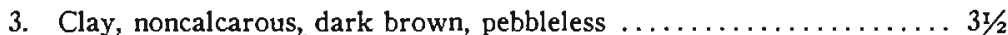

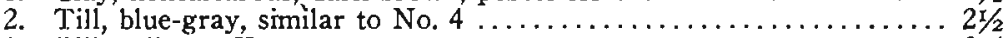

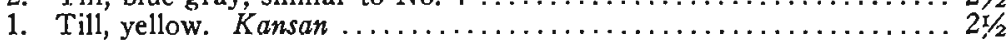

All the material below the pebble layer (No. 6) probably is Kansan drift, numbers 4, 3 and 2, which are not typical Kansan, being interpreted as included material. It appears that the noncalcareous brown clay (No. 3) is material gathered up from some surface by the Kansan ice sheet. The marginal parts of this included mass became mixed with the Kansan till, forming horizons 4 and 2 above and below it. The exposure was so badly slumped that it was not possible to determine the lateral extent of zone 3 , but it is not present generally throughout the. cut.

An alternative interpretation for the foregoing exposure is to extend the Iowan west of Mill creek and Little Sioux river and make zones 5 and 4 Iowan till. Zone 3, the brown noncalcareous, pebbleless clay, would then be the leached Loveland loess resting on Kansan till. An exposure along the highway in the northeast part of section 28 also showed some dark leached clay, but its relation to the till could not be determined. However, if the Iowan is extended west of Little Sioux river at Cherokee, one cannot see why it should not extend on west across western Cherokee and Plymouth counties. It seems better to interpret the noncalcareous material as an inclusion.

Near the south end of this large cut, where the till had passed below the grade, the following section was measured.

. FEET

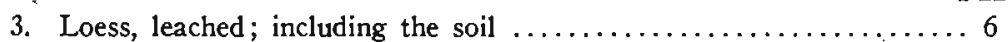

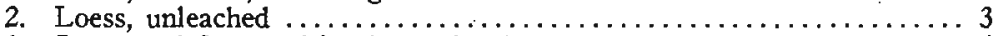

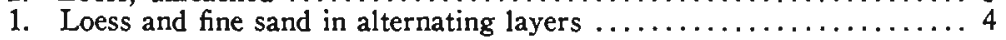

A small cut at the level of the upland just northwest of the buildings showed:

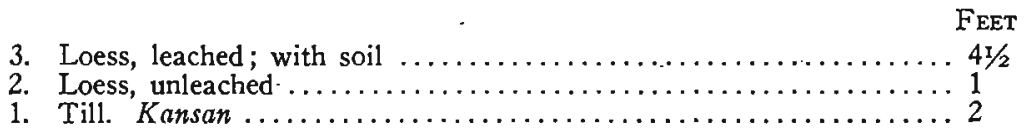

This illustrates the usual thinning of the loess on the hilltops as compared with the east or north slopes.

About a mile southwest of Cherokee, in the north part of the southeast quarter of section 33, on the north slope of a ravine valley, are some abandoned clay pits which show the following section.

FFET

4. Loess, leached; including the soil $\ldots \ldots \ldots \ldots \ldots \ldots \ldots \ldots \ldots \ldots \ldots, 5$

3. Loess, unleached, containing a few concretions ............... 15

2. Loess, sandy, silty, with a few layers of fine sand $\ldots \ldots \ldots \ldots \ldots \ldots \ldots, 5$

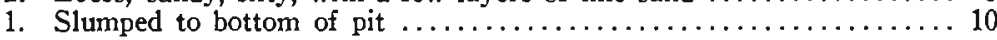

The material in the lower part of the exposure (No. 2) has a faint hori- 
zontal banding and may be partly waterlaid. It grades upward into the more typical loess, which here has an exceptional thickness for this region. The unleached loess (No. 3 ) is filled with the brown threadlike rootlet impressions which are characteristic of the loess. The top zone of leached loess is the same as that which is found in most road cuts. It is believed that number 2 and possibly part or all of number 3 represent the Loveland, here directly overlain by the Peorian. loess. This deposit was formerly used for the manufacture of brick and tile.

Western Cherokee and eastern Plymouth counties have a loess mantle of sufficient thickness to conceal the till on all but the steeper slopes. The shallow road cuts show dark soil passing into the leached loesslike clay below. Some cuts of four feet or more in the loess show the unleached phase. An exposure just south of the northwest corner of section 29, Sheridan township, Cherokee county, showed the usual horizons.

Loess, leached $\ldots$

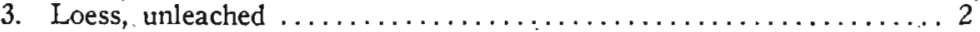

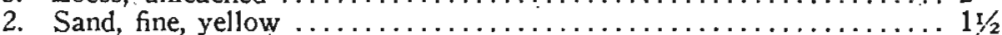

1. Till, yellow. Kansan ................................ 1

On the west side of the West Fork of Little Sioux river in the south part of section 23, Amherst township, a gravel pit showed the following section, which includes the horizons commonly existing along the valleys.

FEET

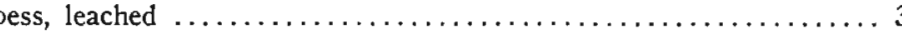

4. Loess, unleached, with pebbles in basal 6 inches ...............

3. Sand with pebbles and becoming more dayey above $\ldots \ldots \ldots \ldots \ldots \ldots$

2. Gravel, medium-grained, with a few cobbles $\ldots \ldots \ldots \ldots \ldots \ldots \ldots \ldots$

1. Till, fresh, yellow. Kansan ......................

Similar conditions continue for several miles west of LeMars, but. within the more rugged country the loess is thicker and the unleached concretion-bearing phase is at the surface.

About 40 rods south of the northwest corner of section 32 of Henry township, Plymouth county, the following section was exposed.

2. Loess, buff, calcareous, Peorian ......................... 8

Contains many calcareous concretions and has some fine-grained sand in basal part.

1. Loess, brownish gray, leached. Loveland ................ $31 / 2$ Contains some calcareous concretions, apparently of material carried in from above.

Another cut near by showed Kansan till beneath the brownish gray loess.

O'Brien and Sioux Counties.-At Sutherland, in southeastern O'Brien county, at the southwest corner of town, a post. auger hole was bored through soil and leached loess to a depth of three feet and eight inches without reaching the base of the loess. In the east part of town are 
several pits in the gravel deposit along the headwaters of Murry creek that show $3 \mathrm{r} / 2$ feet of leached loess overlying the gravel.

Road cuts in northern Cherokee and O'Brien counties commonly show the black soil, which at a depth of 12 to 18 inches grades into the yellow leached loess. 'If the exposure is over three feet deep the unleached yellow till is commonly shown. A good series of road cuts was exposed along the township line road leading south from Primghar. One of these road cuts in the southwest quarter of section 7 , Highland township, showed $3 \mathrm{I} / 2$ feet of leached loess overlying unleached till of the Iowan type. A road cut passing beneath the railway on the east line of section 12, Union township, showed five feet of leached loess over 12 feet of light yellow calcareous till which apparently is Iowan. An exposure near the southwest corner of section 8 , Liberty township, showed from above downward: (1) Leached loess, $3 \mathrm{r} / 2$ feet; (2) unleached gray gravel, 8 feet; (3) yellow Iowan till.

About half a mile north of the Sheldon railway station in a cut on the Chicago, St. Paul, Minneapolis and Omaha railway, the following section was measured.

Fert

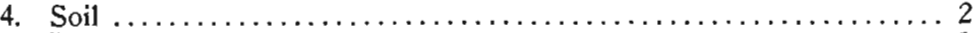

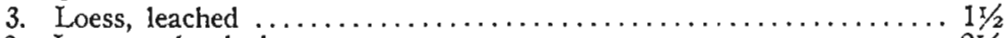

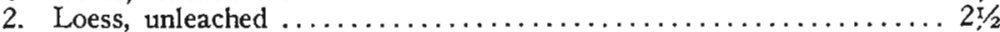

1. Till with calcareous concretions $\ldots \ldots \ldots \ldots \ldots \ldots \ldots \ldots \ldots \ldots \ldots$

Farther north near the crossing of Floyd river, abandoned gravel pits show a zone of leached loess three to five feet thick overlying the gravel. All these exposures of O'Brien county are in the Iowan region.

In Sioux county, Sheridan township, at the southwest corner of section 29 , an excavation for a storm cave in the schoolhouse yard showed eight feet of loess, the larger part of which is leached. Below the loess is a thin layer of sand and pebbles and then the unleached Kansan till. Two miles north, at the southeast corner of section 18, in the schoolhouse yard, material thrown from an excavation for a storm cave showed that the loess has a similar depth, for the till was not reached. At the northeast corner of section 32, Lincoln township, an excavation for a cistern showed 10 feet of loess without reaching its base. Careful search on the walls of the cistern and of the material thrown out did not show a single pebble.

Farther west in Sioux county, loess exposures are numerous but commonly show only the leached loess, except in the more rugged region near Big Sioux river, where unleached concretion-bearing loess is found.

Clay and Dickinson Counties.-In Clay county, Douglas township, near the quarter-corner on the south of section 25, an open trench showed the following : 


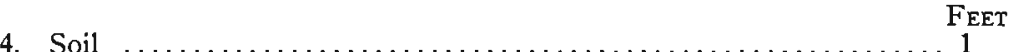

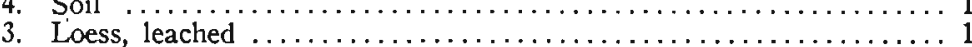

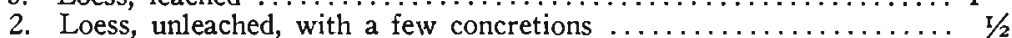

1. Till, yellow, with a few concretions $\ldots \ldots \ldots \ldots \ldots \ldots \ldots \ldots \ldots \ldots \ldots \ldots \ldots$

This exposure is just half a mile west of the north-south center line of Clay county and within four miles of the Wisconsin boundary across the Little Sioux valley, but the loess horizon, although thin, is sufficiently well developed to be definitely recognized. To the north in central Clay county, towards Spencer, the loess horizon is thinner and in some places, where it is less than two feet thick, it is not a definite loess zone. It forms, however, a thin mantle of dark to yellow clay commonly concealing the till and when it is traced from the counties to the west it is seen to be very definitely the equivalent of the loess. This is the condition over northern Clay and southwestern Dickinson counties outside the Wisconsin boundary.

Osceola and Lyon Counties.-In southeastern Osceola county, Harrison township, on the south line of the southwest quarter of section 2, a post auger hole gave the following section.

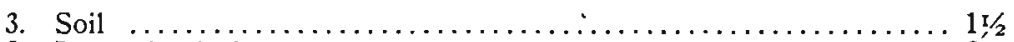

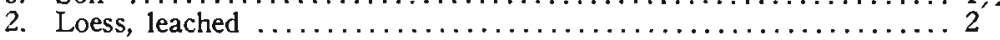

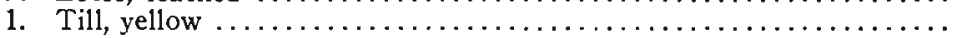

On the west line of section 3, Harrison township, an open trench showed the following:

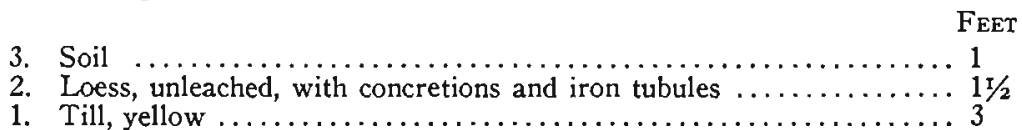

On the north line of the northwest quarter of section 28 , Ocheyedan township, a post auger hole gave the following section.

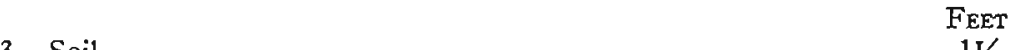

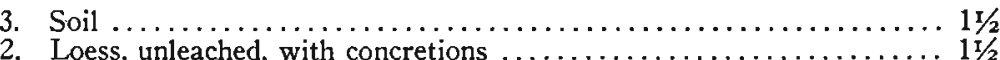

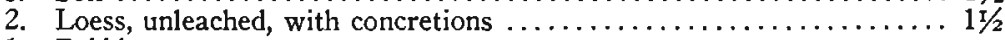

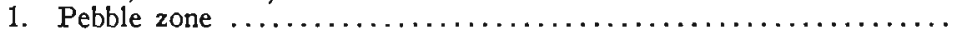

All three of these sections are within one mile of the Wisconsin drift boundary and yet they show the loess horizon.

Road cut exposures in southern Osceola county commonly show the leached loess, which has a thickness of $2 \frac{1}{2}$ feet and rests directly on the unleached till.

At Sibley, a trench just east of the intersection of the main streets showed the following section:

FEET

4. Fill, chiefly of black soil $\ldots \ldots \ldots \ldots \ldots \ldots \ldots \ldots \ldots \ldots \ldots$

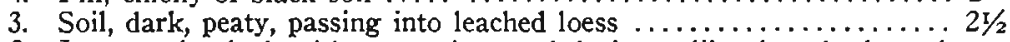

2. Loess, unleached, with concretions and dark rootlike threads through

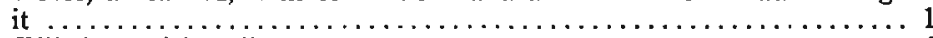

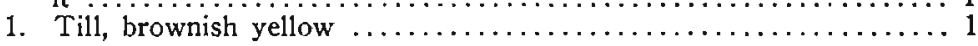


This trench was open from the intersection of the main streets south for two blocks to the Rock Island railway and the loess was essentially the same all the way. At the first street crossing (near Windsor Hotel) gravel appeared below the loess and thickened to the south until the till dropped below the bottom of the trench. The gravel was said to be five feet thick near the railway. An open trench east of the park in the northeast part of town showed similar relations of the loess, till and gravel (figure 18, page 143), and the gravel of the pits in the east part of Sibley is overlain by three to four feet of leached loess.

At Little Rock, in northeastern Lyon county, a cellar excavation in the west part of town showed the following:

FEET

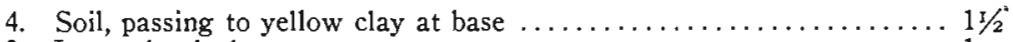

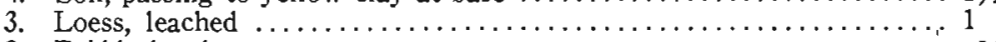

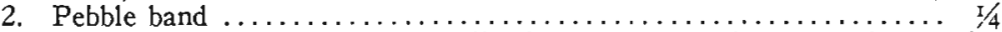

1. Till, unleached, yellow, with small calcareous concretions near the top 6

Other exposures in the region show $2 \mathrm{I} / 2$ to 3 feet of leached loess, as near the southeast corner of section 35 , at the northeast corner of section 22, and near the southeast corner of section 18, all in Elgin township. All of these exposures noted in Osceola and Lyon counties are in the Iowan drift region. Farther west, in Lyon county, on the Kansan region, the leached loess may be seen in many exposures, and in the more rolling country near the Big Sioux the unleached loess with concretions is commonly exposed.

Southern Nobles County, Minnesota.-The study of the loesslike clay was continued about 10 miles north of the state line to Adrian in Nobles county, Minnesota. At the southwest corner of section 28, Ransom township, less than two miles from the Wisconsin drift boundary, a post auger hole exposed $2 \mathrm{r} / 2$ feet of soil and loesslike clay overlying yellow till with calcareous concretions.

At the quarter-corner on the east line of section 19, Little Rock township, a post hole showed the following section.

FeEt

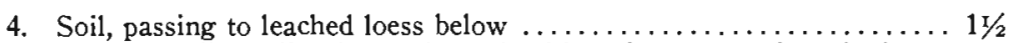

3. Clay, loesslike, slightly sandy and with a few concretions in lower

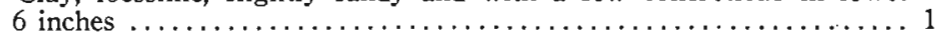

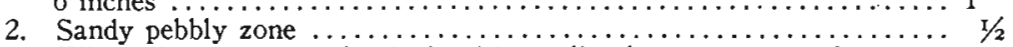

1. Till, yellow-brown, unleached, with small calcareous concretions ....

At the quarter-corner on the east of section 12, Grand Prairie township, a post hole showed the following:

FEET

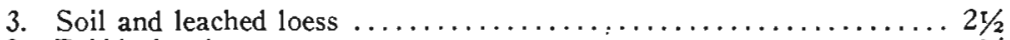

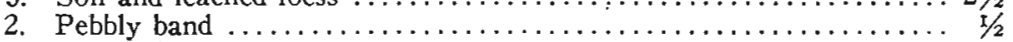

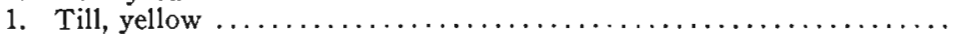


Three miles south of Adrian at the southeast corner of West Side township, a post hole showed the following:

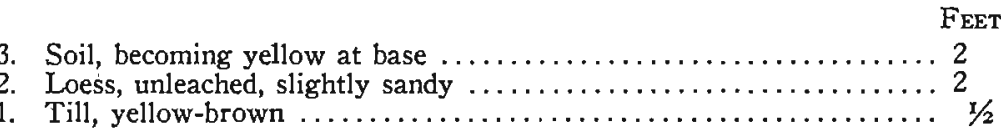

The last three records are located along the crest of the ridge running south from Adrian which Wilder interpreted as the Altamont moraine ${ }^{42}$ and are within the area mapped by Leverett and Sardeson as Wisconsin outside the prominent moraine. ${ }^{43}$

The loess mantle in the Adrian region is thin, as the area is far to the northeast of the region of thick loess and so is similar to Clay and southern Dickinson counties farther south. The exposures east of Adrian are not of the typical leached loess, but sand grains exist more or less throughout the whole of it. It is, however, the equivalent of the loess mantle.

\section{ORIGIN AND AGE OF THE LOESS}

That loess is of eolian origin has become firmly established. ${ }^{44}$ The chief source of the loess material of our region was the valley flats of the great rivers forming the west line of the state; especially Missouri river, and because the prevailing winds of the region are from the west, the thickness deposited and the extent of the mantle are greater to the east than to the west of the valleys. The greatest thickness was deposited near the Missouri and Big Sioux river valleys in western Woodbury and Plymouth counties, where thicknesses of 30 to 50 feet exist, producing the distinctive loess-formed topography of that region. With increasing distance to the east and northeast the thickness of loess deposited decreased. It was 10 to 20 feet over Woodbury, Ida, southwestern Sac and western Plymouth counties; it was five to ten feet over western Cherokee, eastern Plymouth, Sioux and Lyon counties; it was three to six feet in northwestern Sac, eastern Cherokee, western Buena Vista, O'Brien and western Osceola counties; and it decreased to one to three feet in Clay and southwestern Dickinson counties. It covered all the Kansan drift region and all the Iowan drift region now exposed eastward to the Wisconsin boundary, although in Clay county it was very thin.

At the south end of the Iowan area in southwestern Sac county the

42 Iowa Geol. Survey, Vol. X, pp. 132-135, 1900.

48 Minnesota Geol. Survey, Bull. 14, p. 51 and map in pocket.

44 A bibliography on loess is given in Iowa Geol. Sarvey, Vol. XXII, pp. 582-592. Professor Shimek discusses the matter briefly, from the standpoint of the evidence of western Iowa, in Vol. XX, pp. 399-405, and lists in a footnote on page 399 some of his more important papers on the subject. 
thickness of the loess decreases abruptly at the Iowan boundary from 10 to 20 feet on the Kansan region to the south to three to five feet on the Iowan. This suggests that the Iowan region was protected in some way, possibly by the presence of the ice, or that conditions were more. favorable for accumulation on the Kansan region: This abrupt thinning of the loess at the boundary is similar to the condition which exists around the southern border of the Iowan area of northeastern Iowa. Farther northward, where the thick loess does not approach the Iowan boundary, the thinner loess mantle passes across this boundary without any perceptible change.

Little evidence exists in northwestern Iowa as to the exact age of the loess. This is due to the questions as to the exact age of the drift sheets of the region. Just south of our region in Craw ford and Carroll counties the Missouri river loess mantles a mature erosional topography which was developed from the Kansan gumbotil plain. It is, therefore, later than the erosion of the Kansan gumbotil plain. This loess mantle of Crawford and Carroll counties is without doubt the one that continues over all of northwestern Iowa to the Wisconsin drift boundary. The loess terminates on the east at the Wisconsin boundary, and in Carroll county to the south there are exposures showing the Wisconsin drift on top of the loess. ${ }^{45}$ The loess is, therefore, preWisconsin.

It is generally agreed that the great loess deposit of the Missouri river region is of the same age as the great loess deposit of eastern Iowa, which is placed in the Peorian interglacial age and seems to have followed closely the Iowan ice age. If this correlation of the great loess deposits of western and eastern Iowa is correct, then it follows that the loess of northwestern Iowa east to the Wisconsin boundary is Peorian in age.

The significance of the determination recorded above, that the equivalent of the Missouri river loess continues unbroken to the Wisconsin boundary, is that it makes the "intermediate" region pre-Missouri-river loess in age and, by the correlation noted above, pre-Peorian in age. Since the loess of this region rests directly upon a fresh, unleached till, it would seem to follow that this till is Iowan; that is, that the "intermediate" region is an Iowan drift region in northwestern Iowa, similar to the Iowan region in northeastern Iowa. However, this correla-

45 Iowa Geol. Survey, Vol. IX, pp. 89.92, 1899. 
tion of the till of the "intermediate" region with the Iowan, on the basis of the freshness of the till beneath the loess, is not very strong, since the till of all of northwestern Iowa over the Kansan region as well is fresh, unleached till, and it has not been possible in most cases to differentiate a till distinct from the Kansan in the "intermediate" region. 


\section{CHAPTER V}

\section{THE VALLEY ,GRAVELS}

Gravel deposits exist along many of the stream courses of northwestern Iowa. They are found along the larger rivers, along the medium-sized streams, along the small creeks even nearly to their heads on the uplands, and they fill in certain broad areas on the headwaters of some of the streams. As a rule the present stream channels are cut into the gravel fillings, while the parts which remain form terraces which differ greatly in height, some of them being as much as 100 feet above the streams.

The valley gravels are present in both the Iowan and the Kansan drift regions. In both regions they lie upon unleached yellow till and are overlain by loesslike clay which has been shown to be the continuation of the Missouri river loess. There are also gravels within the valleys of the Wisconsin drift region, but these gravels are not discussed here. Several of the larger rivers of northwestern Iowa head northeastward within or along the Wisconsin drift margin and therefore must have carried drainage from the Wisconsin ice. This is true of Big Sioux, Rock, Little Sioux and Boyer rivers. The drainage basins of Floyd and Maple rivers, however, are entirely beyond the margin of the Wisconsin ice. Also many of the tributaries of those stream valleys which carried Wisconsin drainage are entirely beyond the margin of the Wisconsin ice.

Most of the valley gravels appear to have originated within the Iowan drift region apparently as outwash from the Iowan ice sheet. This material was gathered into the valleys of the Iowan area and some of it was deposited there. Some of it was carried on southwest down the valleys into the Kansan region and deposited. This will account for most of the valley gravels of the Kansan region, but not for all of them. The gravels of certain valleys of the Kansan region could not possibly have come from the Iowan ice sheet as here interpreted and mapped. In fact, it would probably be necessary to extend the Iowan over all of northwestern Iowa, at least as far south as Crawford and Carroll counties, to make such an origin possible for all the gravels. These gravels must, therefore, have originated in the Kansan 
region. It is not possible to distinguish the gravels of Iowan age from those that originated in the Kansan region so alike are they in their general characteristics. Further, in both regions they rest on unleached till and are overlain by loess.

\section{NATURE OF THE GRAVELS}

The material is mostly coarse sand and fine gravel, and the extremes in either direction, coarse gravel or silty sand, are rare. The material is horizontally bedded, but not well assorted and the layers in most cases are 10 to 12 inches thick rather than thin beds. Some of the layers are cross-bedded, with lens and basin structures. Another common condition, especially along small valleys, is thick layers of sand with small pebbles up to one or two inches in diameter scattered through it.

The material is distinctly fresh and commonly is without the least indication of iron-rusting or other alteration. Much of the sand, 70 to 80 per cent of the whole, is quartz." Among the pebbles there are many kinds of rocks, but gray limestone pebbles are most abundant and give to the whole deposit a light color. The average of eightyeight analyses of pebbles from the valley gravels is: Igneous rocks 37 per "cent, of whìch 23 per cent are granite; and sedimentary rocks 63 per cent, of which 56 per cent are limestone (pages 176 to 180 ). The percentage of the igneous and other resistant kinds of pebbles is larger down the yalleys and to the west and southwest. In comparison with the material of the gravel hills, these valley gravels contain 13 per cent more of igneous rocks. This is perhaps the result of the destruction of the clay-balls and shale pebbles and a consequent relative increase of other kinds. The number of limestone pebbles worn out largely offsets the relative increase due to the destruction of the clay-balls, "so that most of the increase is in the igneous rock pebbles.

\section{DISTRIBUTION AND DESCRIPTION OF THE VALLEY GRAVELS The Big Sioux River Drainage Basin The Main Valley}

Big Sioux river drained the east margin of the Dakota lobe of the Wisconsin ice sheet from the head of the Coteau des Prairies southward to Canton, and received through its larger tributaries drainage rfrom the west margin of the Des Moines lobe. It also received the drainage from the Iowan ice edge in southwestern Minnesota and in 
Lyon county, Iowa. The valley contains a gravel deposit south of the northwest corner of Iowa and at several places this deposit forms. prominent terraces. These gravels and these terraces were not studied in sufficient detail to separate the Iowan and Wisconsin, if in fact this can be done.

Near the northwest corner of the state, west and northwest of Granite (Plate I), there is a terrace area two miles long and one-half to threefourths of a mile wide (Granite terrace). The surface altitude is 1330 to 1345 feet above sea level; or 80 to 90 feet above the river. At the south end of the bridge on the west line of section 19 just west of Granite, the terrace gravel is 20 feet thick and rests on Kansan till, which continues down to the creek level, 20 to 25 feet lower. The north slope of the valley at this place shows 20 to 25 feet of fresh gravel and sand below the terrace. About a mile west of Granite, in the southwest quarter of section 24, the Chicago, Rock Island \& Pacific Railway Company formerly operated a gravel pit in the terrace. The following section was exposed in the pit and in a gully below.

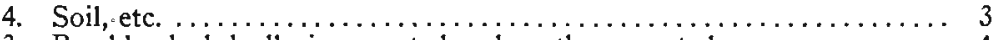

3. Bowlder bed, badly iron-rusted and partly cemented $\ldots \ldots \ldots \ldots \ldots \ldots .4$

The coarse-grained igneous bowlders are rotted, and the limestones are decayed to brown masses.

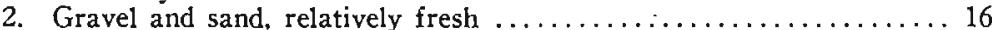

1. Till, brownish yellow. Kansan ..................... 35

Continuous exposure for 5 feet at top and at intervals for 30 feet.

The gravel horizon in the two exposures noted has a thickness of about 20 feet, but these exposures are located along the continuation of Blood Run valley across the terrace, and the average thickness of the deposit over the whole area is probably less.

South of Blood Run the terrace continues as a narrower belt across sections 26 and 35 and is terminated by an eastward bend of the river just south of the township line. It begins again in section 7 , Centennial township, and with a width of about a mile continues south to Klondike (Klondike terrace). The Klondike terrace is only 45 to 55 feet above the river or 30 to 40 feet lower than the Granite terrace. The material was seen just east' of the bridge at Klondike, where it is a coarse gravelly deposit, and in the north part of section 17, where it is largely coarse gravel with bowlders and is partly cemented. In the latter exposure the gravel rests on a tough dark drift which Shimek interpreted as "probable Nebraskan".,6

From Klondike south to Canton the river follows the Iowa bluff, and

46 Shimek, B., Pleistocene of Sioux Falls and Vicinity: Bull. Geol. Soc. Amer., Vol. 23, p. 144, 1912 . 
the Dakota side, although rising gradually, does not present a distinct terrace. Along this portion of the Big Sioux valley the Dakota lobe of ice pushed up to the river and such gravel deposits as exist are probably of Wisconsin age.

South of Canton, terraces appear at various places along the valley to Hawarden and Chatsworth. The river swings from side to side of the valley and the terraces are found here on one side and there on the other. The altitude of these benches is 20 to 30 feet above the river, decreasing southward.

\section{Rock River Valley}

Rock river heads in northeastern Pipestone county, Minnesota, on the slope of the Coteau des Prairies. It drains most of the Iowan belt in Minnesota and has the heads of its several branches in the edge of the Wisconsin region. Rock river enters Iowa at the center of the north line of Lyon county and flows southward and southwestward across Lyon and northwestern Sioux counties to Big Sioux river. Aided by its tributaries from the east it drained about 50 miles of the Wisconsin ice margin and an equal length of the Iowan belt. It was, therefore, well located to receive gravel deposits from both of these ice sheets.

South of the state line the valley flat is about a mile wide, and much of this flat is a terrace about 25 feet above the river. Rock Rapids, Doon and Rock Valley are located on this terrace. At the mouth of Rock river valley the terrace unites with that of the Big Sioux, making a large level plain several miles across.

At Rock Rapids the gravel is 25 to 30 feet thick and rests on yellow Kansan till. A pit about half a mile north of Rock Rapids showed crossbedding and basin structure and variations in the coarseness of the material. At Doon the gravel deposits have been extensively worked in the past by the Great Northern Railway Company. A pit face here showed 25 feet of gravel, which was: said to continue without change for at least five feet below the pit bottom. At Rock Valley the town well is 18 feet deep and is entirely in gravel, and the Chicago, Milwaukee, St. Paul \& Pacific Railway pit west of town has a depth of 20 feet, without reaching the base of the gravel. The material exposed at all these places along Rock River is relatively fresh, oxidized but unleached, and consists of sand and fine-grained gravel with few cobbles or bowlders. Cross-bedding, inclined-bedding and basin structure are common. 
Tributaries of Rock River

Little Rock River and Otter Creck.-Little Rock river, the principal tributary of Rock river from the east, heads in southern Nobles county, Minnesota, within and along the Wisconsin drift margin. In Iowa it crosses the northwest corner of Osceola county and flows south and west across eastern Lyon county to its union with Rock river. Its course southward to where Otter creek enters is within or along the margin of the Iowan area. This stream, therefore, like Rock river carried both Iowan and Wisconsin drainage. There are gravel deposits along the valley at various places, forming indistinct benches which merge more or less gradually with the flood-plain level which forms the major part of the area between the valley slopes. On the Lyon county map Wilder showed this area as a Wisconsin gravel train with a width of about half a mile and extending continuously along the stream.

Just opposite Little Rock there is a low terrace with gravel exposures, and in the northeast part of the town is a small gravel pit in the terrace. The material is horizontally bedded and consists of fresh gravel and sand which is poorly assorted. The gravel of the pit is overlain by two feet of sandy, loesslike material which grades into the soil above.

At George, 10 miles below Little Rock, the terrace on the north side of the valley is almost half a mile wide and 15 feet above the river. The south part of the village is on this terrace, and the town well, southeast of the railway station, has the following $\log$.

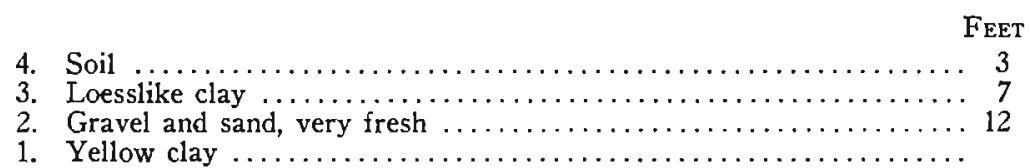

Otter creek heads just within the Wisconsin drift margin north of Bigelow, Minnesota, flows south along this margin for several miles and at the time of maximum glacial advance drained about 10 miles of the icemargin. It has an irregular course southward across western Osceola county, and thence flows west and north in southeastern Lyon county to its union with Little Rock river southwest of George. Its entire course is within or along the margin of the Iowan drift region.

This valley has very little gravel in its upper course near the Wisconsin drift margin, but from Gilman township in southwestern Osceola county across southeastern Lyon county gravel terraces are common. The material exposed in the terrace at Ashton is fresh, only the coarse-grained biotite granites being altered. An analysis of pebbles here showed the presence of 35 per cent igneous rocks and 65 per cent sedimentary rocks, 64 per cent of the latter being gray and buff limestones. On the county line 
northeast of Matlock, Otter creek valley is a broad shallow depression with a broad flood plain and a narrower gravel terrace about 15 feet above the stream.

Rat creek, a tributary of Otter creek in southeastern Lyon county, flows in a broad.sag 15 to 25 feet below the upland. The valley contains some gravel, and indefinite low benches appear at several places. On the Lyon county map, Wilder mapped a Wisconsin gravel train along the entire length of this creek. The valley is in the Iowan drift region, entirely beyond the $W$ isconsin region, and did not receive $W$ isconsin outwash.

Area East and Southeast of Sibley.-At the edge of Sibley there are some large gravel pits in a deposit that is not along any present stream course. The deposit has an areal extent of at least 80 acres and underlies the east and south parts of Sibley. In the City pit 25 to 30 feet of gravel and sand were exposed, and the Chicago, Rock Island \& Pacific Railway pit to the south showed 18 feet of gravel. The gravel rests on an uneven surface of unleached till, which at one place in the City pit slopes four feet in a horizontal distance of 30 feet, and greater irregularities are said to exist. Several mounds of till appear in that part of the railway pit from which the gravel has been removed. One of these consists of a mass of till with the gravel beneath it on at least one side, and in another the till has irregular contacts with the surrounding gravel, and may also be an included mass of till.

A small pit just west of the larger pits showed, in 1927, a lens of till 25 feet across on the pit face and four feet thick, at the top of the gravel horizon. It is light yellow unleached till, resting on unleached gravel and is overlain by $31 / 2$ feet of leached loess. The gravel and till are certainly of the same age and certainly Iowan.

The gravel of these pits is, in general, fresh. At the top is a zone of coarse material, several feet thick, which is iron-stained, and near its base the gravel is in places stained a dark color. A well in this gravel area in the east part of Sibley stopped on a "cement rock" layer which is probably at the base of the gravel. Most of the dark coarse-grained igneous rock pebbles are decayed so as to crumble easily, limestone pebbles are abundant and unaltered, and many layers or laminæ contain a large percentage of grains of shale. The gravel is medium-grained and quite uniform. Bowlders are rare except at the base of the gravel, where they rest on the till.

A sewer pipe trench along the street just east of the City Park in the northeast part of Sibley was open in August, 1911, and showed at the south, sand and gravel overlain by loess. To the north fresh till rose above the level of the bottom of the ditch, the sand and gravel horizon 
thinned to zero, and the loess rested on the till. A sketch of this exposure is shown in figure 18. The exposure was apparently at the edge of the

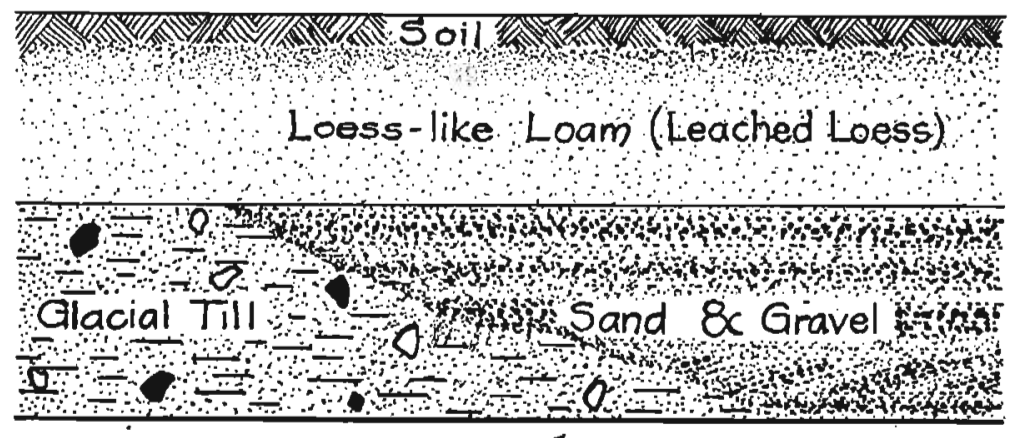

FIG. 18.-Sketch of exposure in side of sewer pipe trench in the northeast part of Sibley. It shows the relation of the gravel horizon to the till, and of the loess to both the gravel and the till.

gravel deposit and showed the relation of the gravel to the till and the relation of the loess to both the gravel and till. None of the contacts showed any alteration. Similar conditions were seen in an open trench along the north-south main street of Sibley at the street crossing near the Windsor Hotel (page 133).

Two miles. southeast of Sibley, in the northeast quarter of section 30; East Holman township, a gravel pit operated by the Chicago, Rock Island \& Pacific Railway Company exposed material similar to that at Sibley except that the upper part is coarser and more bowldery. Eighteen feet of gravel was exposed beneath a five-foot zone of loesslike clay. A considerable area south of this pit in sections 30 and 29 is quite level and is probably underlain with gravel.

The margin of the Wisconsin drift as traced by the writer is only a few miles to the northeast of these deposits east and southeast of Sibley, but the small valleys leading away from this Wisconsin drift margin show no indication of having carried outwash material, and the small valley of section 18, which passes near the deposit east of Sibley, did not head back to the margin of the Wisconsin ice. Also these gravels are overlain by loess :which is older than the Wisconsin epoch and at one place are overlain by a great lens of Iowan till. In appearance and composition these are the typical valley gravels of the Iowan drift region.

Tom Creek.-This creek drains. a part of northeastern Lyon county near the state line and enters Rock river at Rock Rapids. There are gravel terraces along its course and fresh gravel and sand may be seen in several valley pits in Midland township. A similar deposit is found along the north branch of Tom creek. 
Tom creek and Little Rock river drain the area in northeastern Lyon county mapped by Wilder as Wisconsin outwash. ${ }^{47}$ Otter creek drains the similar outwash area in northwestern Osceola county. Although these areas have some gravel outside the present valleys, it is not sufficient to form an outwash plain and they are not related to the Wisconsin boundary. Several of the more important gravel deposits along these valleys are overlain with loess and probably essentially all of the gravel is of Iowan age.

Mud Creek.-This creek heads in the southern part of Rock county, Minnesota, and flows south by southeast across Lyon county to Rock river near Doon. From the state line southward the valley is broad with gentle slopes and a flat bottom. This flat is, as a rule, a flood plain, but benches of gravel appear at many places. The gravel is fresh and consists of relatively resistant material. Three analyses of pebbles from benches along this valley show an average content of 51 per cent of igneous rocks, which is 14 per cent higher than the average for pebbles from the valley gravels. The analyses also show a high percentage of quartzites and cherts, which are classed with the sedimentary pebbles. This valley is entirely within the Kansan drift area and could not possibly have received any outwash from the Iowan area as here mapped.

Rock river, Little Rock river and Otter creek all head at the Wisconsin margin and therefore carried Wisconsin drainage. The headward courses of Rock and Little Rock rivers in Minnesota were not studied but the upper course of Otter creek valley does not contain much gravel. Further, the gravel of these valleys is overlain by the loess or loesslike clay that covers the Kansan and Iowan drift regions and which is older than the Wisconsin. These gravels are, therefore, believed to be of Iowan age. The gravels just east and southeast of Sibley, within the Iowan area and those along Tom creek in Midland township, just outside the Iowan area, apparently are of Iowan age. The gravels along Mud creek in western Lyon county could not have been derived from the Iowan and are believed to have been released from the Kansan till by erosion and to have accumulated in the valley. The greater dominance of the resistant types of pebbles might be thus accounted for.

\section{Small Tributaries of the Big Sioux}

None of the creeks considered under this heading is more than six to ten miles long and all lie. entirely within the Kansan drift region. The first of these south of the state line is Blood Run, which flows southwest-

47 Iowa Geol. Survey, Vol. X, p. 135 and map, 1900. 
ward across Sioux township in northwestern Lyon county, and joins the Big Sioux valley west of Granite. The Granite terrace of the Big Sioux valley (page 139) continues into the mouth of Blood Run valley as far as Granite, and gravel deposits appear to the east along the valley through sections 20,21 and 22 .

Plum creek enters the Big Sioux valley along the south edge of the Klondike terrace a few miles south of Blood Run. This creek was not followed, but Beyer describes it as having a low indistinct terrace of small extent, and describes a pit exposure along the creek, three miles south of Larchwood, as showing seven to eight feet of clean sand and gravel resting on the blue clay. ${ }^{48}$

Dry creek and Six Mile creek, in western Sioux county, have broad, open valleys with narrow flood plains, and gravel deposits appear along them at various places, but nowhere do they form benches of any prominence. Similar gravel deposits are found along the creeks of western Plymouth county, especially along Broken Kettle creek, and in this region the gravel is overlain by a deposit which is unquestionably loess. The gravel of all these small tributaries of the Big Sioux must have been derived from the Kansan till.

\section{The Floyd River Drainage Basin The Main Valley}

Next east of the Big Sioux lies the Floyd river basin. This is a smaller basin lying between the Big Sioux and the Little Sioux and is limited to the north by the spread of the basins of its larger neighbors. Floyd river heads in southern Osceola and northern O'Brien counties and flows south by southwest across eastern Sioux and central Plymouth counties to Missouri river at Sioux City. The Floyd drainage basin is separated from the Wisconsin drift area by the high divide of southern Osceola county and certainly received no drainage from the Wisconsin ice. Its headwaters northeast of Sheldon are within the Iowan drift area, of which it drains about 150 square miles. Southwest of Sheldon across Sioux and Plymouth counties the basin is within the Kansan drift region.

In northwestern O'Brien county there are small benches in the Floyd valley 10 to 20 feet above the stream. Exposures in these benches are not common, but one on the west side of the valley on the north line of section 21, Floyd township, showed three feet of horizontally bedded gravel overlain by about 18 inches of leached loess.

48 Iowa Geol. Survey, Vol. XXIV, p. 426, 1914. 
About one mile north of Sheldon on the south side of the Floyd valley there is a large abandoned gravel pit and there are also some smaller pits that are now being worked. In the abandoned pit west of the railway the following section was exposed.

FEET

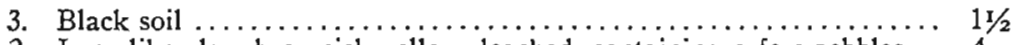

2. Loesslike clay, brownish yellow, leached, containing a few pebbles .. 4

This member grades into the soil above, and in some places, by the inclusion of pebble bands, it grades into the gravel bed below. Although not true loess in the lithological sense, this material is certainly the time equivalent of the loess. Loess exists in the vicinity and rests on the till, as may be seen in a railway cut between these pits and Sheldon (page 131).

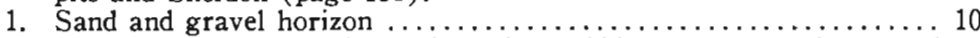

This gravel is fine-grained with a few cobbles, and some of the sand layers show inclined laminæ. The material of the layers changes horizontally in short distances so that any section taken fits only that particular place. The base was not exposed at the pit face but part of the floor of the pit is a cemented zone of cross-bedded sand, probably at the base of the gravel horizon.

In a small pit just north of the large abandoned pit, the gravel rests on unleached brownish yellow till that may be either Kansan or Iowan. A pit on the east side of the railway showed 12 feet of fine gravel. Several clay-balls (till) were found here, this being one of the few places where they were seen in the valley gravels. This is within the Iowan region and the gravels may have been carried only a short distance before deposition.

Southwest of Sheldon, Floyd river has a broad, open valley with a gradually widening valley flat. Patches of terrace about 10 feet above the flood plain exist at many places, and there are gravel pits in these terraces at Hospers, two miles north of Alton, at Alton, Seney and LeMars (Plate I). At the east end of the Chicago \& North Western railway bridge at Alton some pits expose 10 feet of gravel with thin layers of coarse sand, overlain by three feet of loesslike clay, which rises to an indistinct bench 20 feet above the river. Other pits in a bench of similar height north of the railway station show the same loesslike zone overlying the gravel.

A pit near the river in the northwest part of LeMars showed the following section :49

5. Soil, sandy, black $\ldots \ldots \ldots \ldots \ldots \ldots \ldots \ldots \ldots \ldots \ldots \ldots, 4$

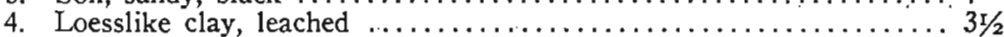

3. Loesslike clay, unleached, with thin layers of sand .......... $6 \mathrm{r} / 2$ The upper part of this zone contains small calcareous concretions.

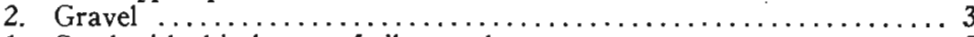

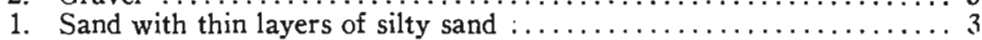

The calcareous material removed by leaching from zone number 4 has been concentrated in the upper part of zone number 3 in the form of con-

49 This or a pit nearby was described and figured by H. F. Bain in his report on Plymouth county. Iowa Geol. Survey, Vol. VIII, p. 338 and Plate 29, figure 2. 
cretions. These two zones are the time equivalent of the loess of the upland and togther form a horizon much thicker here than farther up the Floyd valley at Sheldon. From the pit of B. Erdman just west of the above several limb bones and pieces of deer horns have been taken.

South of LeMars the flat of the Floyd valley is a mile to a mile and a half wide, but it is all essentially at flood-plain level. This flat is probably underlain with gravel.

The Floyd river valley contains gravels from its headwaters to its mouth. In the Iowan area above Sheldon these should be of Jowan age and those farther down the valley may also have been derived from the Iowan area. However, tributary valleys which could not have received Iowan drainage, as the West Fork of Floyd river and Deep creek, contain similar gravels and if these latter were derived by the erosion of the Kansan till, then some of those in the main valley may have been derived from the Kansan.

\section{Deep Creek Valley}

At LeMars Floyd river is joined by Deep creek, which rises in southwestern. O'Brien and southeastern Sioux counties and flows south to Remsen and thence west to Floyd river. Fresh sand and fine gravel appear in benches along this creek, and exposures were seen in every section from Remsen to LeMars. The gravel horizon is overlain by yellow loesslike clay, as in the Floyd river valley.

In the northwest quarter of section 5, Marion township, the terrace is 30 feet above the creek, and a well on the terrace goes 45 feet into sand, or 15 feet below the stream level, without reaching the bottom of the sand. A pit in the northeast quarter of section 4, Marion township, one mile east of Oyens, operated by $\mathrm{C}$. $\mathrm{H}$. Grimes, showed the following section.

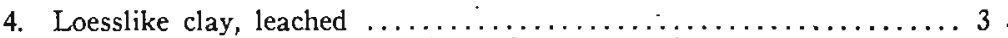

3. Loesslike clay, unleached, with a few bands of pebbles in the basal

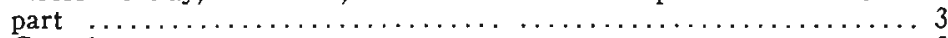

2. Gravel ......................................... 3

1. Sand and gravel; above water level $\ldots \ldots \ldots \ldots \ldots \ldots \ldots \ldots \ldots, 6$

The pit was worked by a suction-dredge to a depth of about 20 feet below water level. The material is sand and fine gravel with some cobbles. Several vertebræ and other bone fragments have been pumped up with the gravel.

In the lower course of Deep creek valley just northeast of LeMars there 
are two pits from which gravel has been dredged beneath water level. One is located in the northeast quarter of section 10 and the other a mile farther west in the northeast quarter of section 9. The pit in section 10, now abandoned, showed the following exposure above water level.

4. Soil, passing downward into yellow, sandy clay ............... 6

3. Alternating layers of fine sand and clayey sand, horizontally bedded

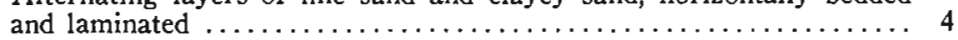

2. Loesslike clay, brownish, with thin partings of sand ............ 6 What are apparently rootlet impressions penetrate this clay, and ironstaining has taken place along these openings.

1. Gravel, fresh, fine-grained, with a few cobbles 4 to 8 inches through;

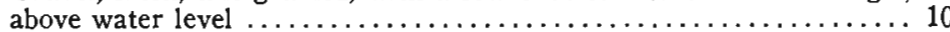

This pit can be worked to a depth of 47 feet below water level, where a layer is struck that is said to consist of flat, slabby pebbles, too hard to be penetrated by the dredge scoop. The material from this pit is fine sand with very little gravel. Details of stratification are of course unknown. At a depth of 25 feet a silty layer with stems and vegetable material is passed through. This was penetrated over the entire pit area, which is 50 to 60 yards across.

The pit in the northeast quarter of section 9 shows the following section above water level.

FeEt

4. Soil, sandy, dark $\ldots \ldots \ldots \ldots \ldots \ldots \ldots \ldots \ldots \ldots \ldots \ldots \ldots \ldots \ldots \ldots$

3. Clay, sandy, dark gray, leached ....................... 4

2. Loesslike clay, unleached, containing thin layers of fine sand ....... 15 This is the usual material overlying the gravels but is here thicker and more sandy than common.

1. Gravel, fine, and sand; above water level ............... 5

Gravel is dredged from this pit to a depth of 30 feet below water level. At this depth a layer of slabby pebbles is struck as in the other pit. Prospect drill-holes have been sunk near by, one of which penetrated 58 feet of gravel below water level. As in the pit farther east, there is, at a depth of 20 to 25 feet, a dark silty layer containing vegetable material.

A number of bones have been dredged up from these pits, but no evidence could be obtained as to the horizon from which they came (page 164). They are not greatly altered and have a more modern appearance than bones from the gravel deposits of western lowa farther south. Six analyses of pebbles from the gravel deposit of Deep creek valley show an average content of 48 per cent igneous rocks, which is about 11 per cent higher than the average for all analyses made of the valley gravels, indicating a greater wear and transportation.

Deep creek is entirely in the Kansan drift region and the explanation of its thick gravel deposit is a rather difficult problem. The valley in which the gravel lies apparently goes through the glacial drift, at 
least in part, for an exposure of Cretaceous rock exists near the level of the creek in the southwest part of section 2, less than half a mile up the valley from the abandoned pit in section 10 , where the gravel was worked to a depth of more than 40 feet below the creek level. Does this deep valley continue down Floyd river to the Missouri? When was the valley eroded, and when was it filled with gravel? Much more evidence concerning these gravel deposits is required before a satisfactory explanation can be given. From the freshness of the gravels and their relation to the overlying loess, it is believed that they were deposited just before the loess deposition or approximately at the time of the Iowan glacial period.

\section{The Little Sioux River Drainage Basin}

The Little Sioux is the largest of the southwestward flowing streams of western Iowa. In common with its chief tributary, the Ocheyedan, it heads on the Wisconsin drift plain, and after passing to the Iowan drift region near Milford in Dickinson county, it flows near the Wisconsin drift margin south to the mouth of Brooke creek, in northwestern Buena Vista county. It received the drainage of the Wisconsin ice front from a point east of Sibley to Storm Lake, a distance of about 100 miles, and at the present time drains more than 1,000 square miles of the Wisconsin drift plain. From the mouth of Brooke creek to Cherokee the Little Sioux crosses the Iowan area and receives important tributaries from this Iowan area from the north. On the whole, it drains more than 1,000 square miles of the Iowan drift region. Southwest of Cherokee the Little Sioux is on the Kansan drift region.

\section{The Headwaters of the Little Sioux above Spencer}

The Little Sioux river system above Spencer consists of the Little Sioux proper, the Ocheyedan with its tributary the Little Ocheyedan, and Stony creek, all of which have their upper courses within the Wisconsin drift region. There are gravel deposits at various places along the Little Sioux within the Wisconsin area in Dickinson county, but on the whole they do not form continuous terrace benches.

The Okoboji outlet, which drains the lakes of north-central Dickinson county, joins the Little Sioux southwest of Milford. This course was the outlet of enormous floods of water during the Wisconsin ice epoch and there are great gravel deposits along the outlet and along the Little Sioux to the south. Gravel exposures are found in the valley sides and 
in pits on the terrace. The thickness of the gravel is 10 to 20 feet and it is coarser and more rusty than is the gravel of most of the deposits that are beyond the reach of the Wisconsin ice drainage. Eight analyses of gravels from the Little Sioux valley between the Wisconsin boundary and Spencer show an average of 41 per cent igneous rocks, which is about 5 per cent higher than the average igneous content of gravels found in valleys that could not have received drainage from the Wisconsin ice.

This gravel area extends as a terrace down the Little Sioux valley to the county line and south to Spencer. At Milford the terrace is 70 to 80 feet above the river, but it declines to 50 feet at the county line, and to 20 feet at Spencer, as shown in figure 19. In this distance the river falls 70

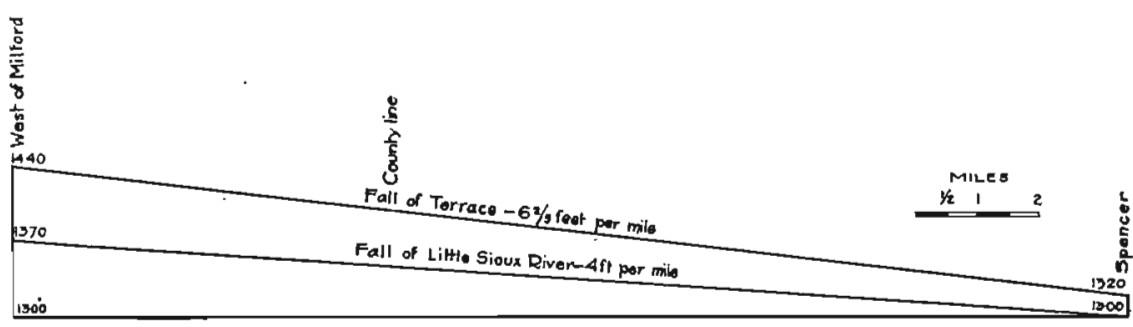

Frg. 19.-Profiles along the Little Sioux river valley from west of Milford to Spencer, showing the gradient of the river and the gradient of the terrace. The distance is measured along the central line of the gravel-filled area.

feet while the terrace drops about 120 feet. The fall of the terrace measured along the center line of the filled belt is $62 / 3$ feet per mile, and the fall of the river along this same line is about four feet per mile. The fall of the river from west of Milford to Spencer, measured along its winding course, is $2 \frac{2}{3}$ feet per mile.

In the pits south of Milford the gravel is overlain by two to three feet of brown sandy, noncalcareous material with few pebbles. It is not the usual leached loess but bears some resemblance to it and, considering the location of the region, where the loess is almost absent on the upland, this may be the equivalent of the loess. Such an interpretation of the overlying material would make the gravel of the Milford bench pre-Wisconsin and place it with the valley gravels of the Iowan age. The more rusty character of the gravel, the location of the deposit with respect to the Wisconsin drift boundary, and the decline of the bench southward to stream level at Spencer seem to separate this gravel deposit from the usual valley gravels and it is most probably Wisconsin outwash. Gravels underlie the valley flats of Ocheyedan river and Stony creek, both of which head within the Wisconsin area and extend out onto the Iowan area to the south, but these flats are low, being little if any above the flood-plain level.

The valley flats of the Ocheyedan, Stony creek and the Little Sioux 
all unite in Riverton township west of Spencer in a large gravel area (Spencer flat) which extends from Everly eastward through Spencer to the southward bend of the Little Sioux southwest of Dickens. It covers the north half of Riverton township, a strip about two miles wide across Sioux township, and continues west and north up the Ocheyedan and Little Sioux valleys. About half of this area is a terrace 15 to 20 feet above the river. Gravel exposures appear at many places. At the pit of the Spencer Cement Tile Company, the gravel is worked to a depth of about 20 feet by a suction-dredge which pumps the gravel from beneath ground water level. About 10 feet of material is exposed above water level, and this consists of cross-bedded fine gravel and sand. Blue clay is said to underlie the gravel, and bowlders have been encountered toward the base of the gravel. The gravel is overlain by a brown sandy material similar to that over the gravel at Milford.

\section{Tributaries of the Little Sioux from the Wisconsin Drift Region}

From Spencer to the mouth of Brooke creek in the northwest part of Buena Vista county the Wisconsin boundary is along or near the east bluff of the Little Sioux and in this distance the valley must have received drainage from the $W$ isconsin ice.

East of Spencer the Little Sioux is joined by Meadow brook, which with its several branches drains those parts of northeastern Clay and southeastern Dickinson counties which lie within the Wisconsin drift boundary. Small gravel deposits are present along this creek at many places in the Wisconsin region but not in quantities sufficient to form terraces. Five miles east of Spencer the Little Sioux is joined by the outlet of Lost Island lake (Dickens outlet), and there are important gravel deposits along this valley south and southeast of Dickens.

Through southeastern. Clay county and northern Buena Vista county west as far as Linn Grove no tributaries of importance enter from the east. Elk creek, entering at Gillett Grove in southeastern Clay county, has very little gravel along its course, although it drained about six miles of the Wisconsin ice margin and now drains probably a township of Wisconsin drift plain. Brooke creek, which flows north along the Wisconsin drift margin to the Little Sioux, drained 18 miles of the Wisconsin ice margin. It has little gravel in its upper course, in Washington and Elk townships, but in its lower course, in Brooke township, there are thick gravel deposits into which the creek and its tributaries have cut deep, narrow valleys. All these tributaries from the east between Spencer and Brooke creek drain the Wisconsin region. 


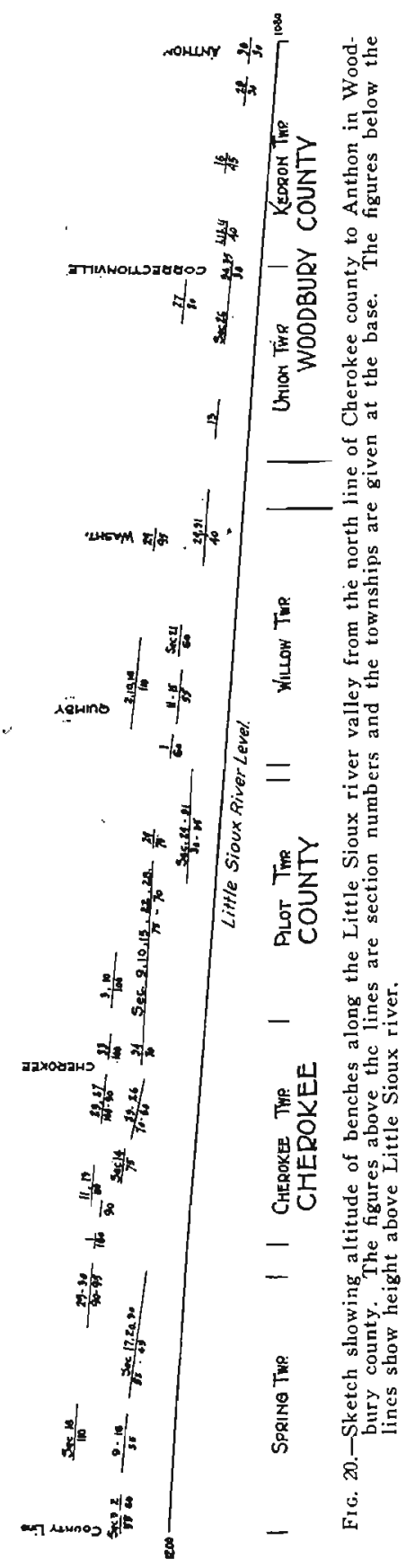

\section{Gravels of the Little Sioux Valley from Spencer to Its Mouth}

From the bend east of Spencer south to Gillett Grove, Little Sioux river flows through a narrow valley and there are practically no gravel deposits. Below Gillett Grove, in Herdland township, there are some small gravel terraces, chiefly along the east slope of the valley, which here marks the Wisconsin drift margin. At Sioux Rapids the station of the Minneapolis and St. Louis Railway is on a bench about 50 feet above the river and a gravel pit just north of the railway station shows 20 feet of gravel. To the west there are benches at several places, usually on the inner side of the great bends of the valley. There are in places one, in places two, and in places three benches, and their altitudes above the river differ greatly. One common elevation is 45 to 60 feet above the river. All these benches are probably composed of Wisconsin gravels derived from the $\mathrm{W}$ isconsin ice front, which lay just to the east.

From the mouth of Brooke creek to Cherokee the course of the Little Sioux is across the Iowan drift region. At the bend of the Little Sioux in southeastern O'Brien county, at the mouth of Waterman creek, there are gravel benches about 115 feet above the river, and only 15 to 25 feet below the adjoining upland. A gravel deposit at this level on the west line of section 23, Waterman township, has a thickness of 30 feet. This terrace continues up Waterman creek valley to the north and up Murry creek valley to Sutherland but is not present along the Little Sioux valley to the east. This is in accord with the interpretation given elsewhere ${ }^{50}$ that 
the Little Sioux river came into its present course across the great divide in Wisconsin time and that Waterman creek is the northward continuation of the pre-Wisconsin Little Sioux.

South of the bend and in Cherokee county two bench levels are common; one near the upland, 100 to 120 feet above the river, and another 50 to 55 feet above the river. The elevations of these benches along the Little Sioux vallev across Cherokee and Woodbury counties are shown in figure 20. In Spring township the higher terrace is found on the north line of section 2 , in the southeast quarter of section 17 , in the west half of section 29 , and at the lower ends of the valleys which enter in sections 16 and 19. The lower terrace is found in sections $3,2,9,16$ and 29 , and as a large area in sections 17,20 and 30 . At many places this terrace grades down to the flood-plain level.

In Cherokee township the higher terrace is found in section 13, along the lower course of Mill creek, and southward to and through Cherokee. Lower terraces of considerable area are found north and south of Cherokee, and the town of Cherokee stands on such an area. There seems to be very little uniformity in the altitude of these benches.

In section 14 there are two pits in the terrace, which is here about 75 feet above the river, that go down into the deposit 50 and 60 feet, respectively. The material is sand and gravel, with a few bowlders. Clay-balls are abundant locally. The material is relatively fresh but oxidized. The pit of the Cherokee Sand and Gravel Company was 60 feet deep, and the bottom was on a bowlder zone which is said to rest on "blue clay". About 80 rods south of this pit is the Gilleas pit which showed a face 50 to 60 feet high, made up of layers of coarse and fine gravel and sand. There are many cobbles and small bowlders in this pit, and some very large bowlders. On the basis of the evidence given elsewhere (page 57) that a great lens of till is interbedded with the upper part of this gravel, it is known to have accumulated during the Iowan ice epoch.

Just south of Cherokee in the southwest quarter of section 34 the Illinois Central Railway Company has removed the gravel from an area of several acres. An exposure in the east end of this pit showed till, probably Kansan, below about 20 feet of gravel.

In Pilot township the most continuous terrace is 70 to 75 feet above the river, but other altitudes are represented. At Washta the lower terrace is not over 40 feet above the river, and the upper one is 95 feet above water level (figure 20). At Correctionville the terraces are still lower, being 30 and 80 feet above the river. Correctionville stands on the lower terrace and the higher one is represented by benches at the mouth of, and within the valley of Pierson creek.

The lower terrace is found in Kedron township south of Correctionville, 
where there is a pit on the west line of section 15; at Anthon, where it is 30 feet above the river; and in sections 17 and 18 of Miller township, three miles south of Anthon. Farther south terraces were not recognized, and practically all of the flat is flood plain, at an elevation of 20 to 25 feet above the river.

The upper bench level was not positively identified south of Correctionville, but masses of gravel were seen at several places high up on the slopes of the valley. In the southwest quarter of section 20, Miller township, there is some oxidized gravel 85 feet above the river; opposite Oto in section 5 there is a gravel deposit about 100 feet above the river; and in section 8 there is an exposure of sand 80 to 90 feet above the river. These materials are all more oxidized than the deposits found north of Correctionville.

Since Little Sioux river drains so large an area of Wisconsin drift, it should have carried much Wisconsin drainage and much gravel along its valley should be of this age. If the course westward across the great watershed is a Wisconsin glacial diversion, then the gravel benches in this part of the valley must be of Wisconsin age. The lower benches across Cherokee and Woodbury counties may be of Wisconsin age. The high bench beginning in southeastern O'Brien county and continuing southward is continuous with benches in valleys that did not receive Wisconsin gravels. Also the gravel of this high bench is overlain by loess in the north part of Cherokee (page 127), in the southwest part of section 31, Pilot township, and at a few other places along the Little Sioux valley and at many places along the courses of the tributary valleys. This upper terrace is, therefore, preloess in age and is interpreted as Iowan.

\section{Tributaries of the Little Sioux from the Iowan Drift Region}

All the tributary valleys of the Little Sioux from the west, between Spencer and Cherokee, drain the Iowan region and did not receive drainage from the Wisconsin ice, and yet these valleys in Clay, O'Brien and Cherokee counties contain prominent gravel deposits, which continue in some cases to the heads of small valleys, whether. these head northward or to the east or to the west toward some of the interstream divides.

Willow Creek.-The first creek of importance which joins the Little Sioux from the west, south of Spencer, is Willow creek.' Along its lower course in section 7, Herdland township, O'Brien county, there is a fresh 
gravel deposit covering a large area and forming benches about 30 feet above the creek and 35 to 40 feet above Little Sioux river. An analysis of pebbles showed the presence of 72 per cent sedimentary rocks, all of which were limestone. These gravels are too far from the mouth of the valley to have-washed back from the Little Sioux and therefore are not of Wisconsin age. They were derived from the Iowan region possibly during the Wisconsin epoch, for the elevation of the bench accords with that in the Little Sioux valley.

Waterman and Murry Creeks.-In its upper course the valley of Waterman creek, which drains eastern O'Brien county, is a broad sag 15 to 20 feet below the general level, but it deepens within a short distance, so that in its lower course it is more than 100 feet below the upland. In western Omega township there is a gravel bench 15 to 20 feet above the valley bottom, and gravel extends down to water level. The altitude of this bench above the stream increases greatly to the south so that in central Grant township it is 70 feet and near the mouth of Waterman creek more than 100 feet above the stream. Here it unites with the high-level bench of the Little Sioux valley. The relation of the slope of the terrace and the gradient of the creek is shown in figure 21. In Grant and Waterman

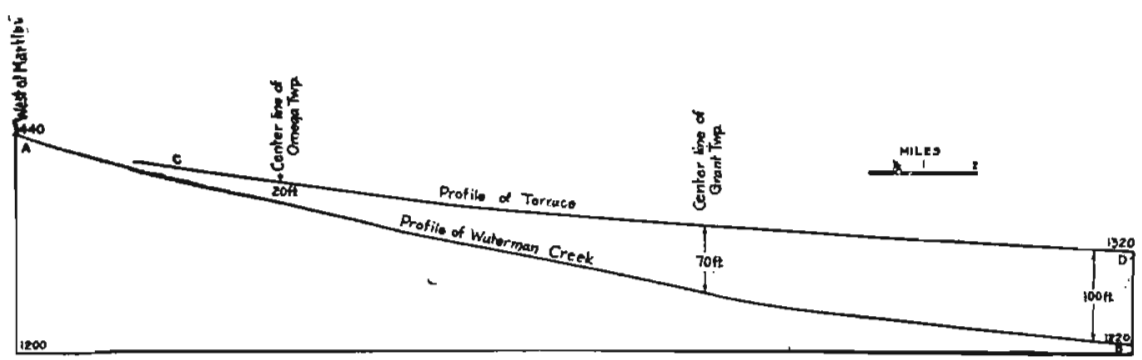

Fig. 21.-Profiles along Waterman creek valley from west of Hartley to its mouth, showing, $A-B$, the gradient of the stream, and, $C-D$, the gradient of the terrace.

townships the terraces have considerable area and the gravel in most of them is 20 to 30 feet thick. Waterman creek and its tributaries have cut narrow, steep-sided valleys in the gravel-covered area, leaving level-topped spurs extending out toward the creek from either side and making a very rugged topography. The gravel material is very uniform, consisting of fine gravel with pebbles.and small cobbles. The sand is coarse- or mediumgrained, subangular, and the larger grains are dominantly limestone and the smaller grains dominantly quartz.

Murry creek is a tributary of Waterman creek. It heads on the east slope of the high divide of O'Brien county, a mile north of Sutherland, and flows south of east to Waterman creek. Its entire length is only about 10 miles. Along its upper course at Sutherland there are several gravel 
pits exposing 10 to 15 feet of fresh gravel which rests on glacial till and is overlain by two to three feet of loesslike clay (leached loess). At Sutherland the gravel terrace is only 15 feet above the stream, but to the east its altitude increases as the stream descends, until at the mouth of the creek the terrace merges with the high-level benches of the Waterman and Little Sioux valleys at 110 feet above the valley bed. The terrace in this distance drops 100 feet while the stream drops 200 feet. The slope of the terrace and the gradient of the stream are shown in figure 22.

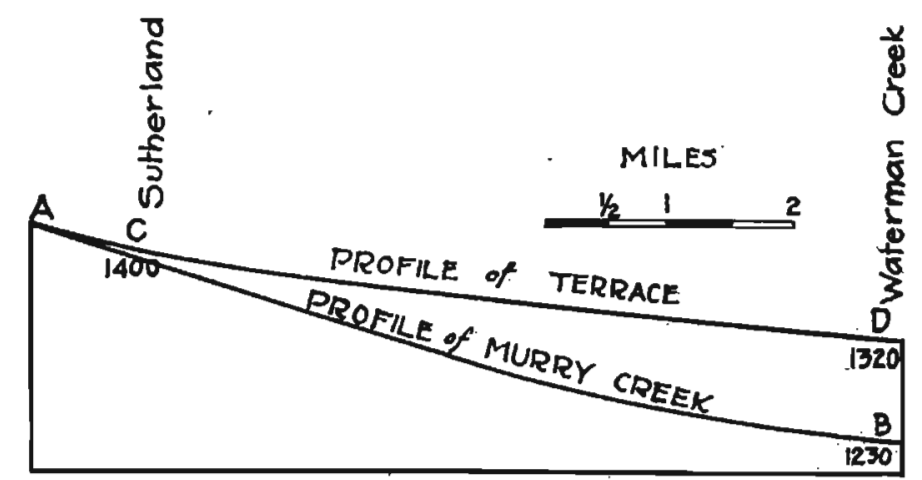

Fig 22.-Profiles along Murry creek valley from Sutherland to its mouth, showing, A-B, the gradient of the creek, and, $C-D$, the gradient of the terrace.

This valley furnishes one of the best examples of the way the gravels exist in small valleys well out on the upland only a mile or so from the head of the stream. It furnishes very positive evidence against the hypothesis of overwash from the Wisconsin ice margin to the north. The stream heads on a north-south divide and numerous streams flowing to the east and west drain the divide farther north. If water could have passed over the high divide south of Ocheyedan river, it would have been carried away either to the east or west by some one of a dozen valleys to the north of Sutherland. The altitude of the gravels at Sutherland is 1415 to 1420 feet above sea level. They are on the slopes of the highest watershed of northwestern Iowa.

Mill Creek.-Mill creek, with its tributaries, drains central and southern O'Brien county and central northern Cherokee county. The territory which it drains in its upper part is quite level but farther south its basin is more rolling, and in northern Cherokee county it is rather rugged. Mill creek did not receive drainage from the Wisconsin ice, for its headwaters are all south of the high divide of southern Osceola county and their gathering grounds are limited on the north by the headwaters of Floyd river and Waterman creek. However, the valleys of Mill creek and its tributaries contain gravel, which in many cases extends nearly to their 
heads on the upland. This applies to creeks heading east and west on the intervalley divides as well as to those heading northward.

Three miles west of Primghar several branches of Mill creek unite, and at their union there is an almost level area covering several square miles which appears to be underlain with gravel. The area is not absolutely flat but rises gradually away from the creek and its boundary is in some places quite indefinite. It has an altitude of about 15 feet above the creek - but is not a definite terrace. Projections of this area extend up stream courses to the northwest, north and northeast, and it continues south beyond the center of Dale township. Wells near the quarter-corners on the south of section 33 and the east of section 32, Summit township, are 20 feet deep in sand and gravel and one at the quarter-corner on the south of 29 is said to be 40 feet deep and all in gravel.

An east branch of Mill creek heads about two miles northeast of Primghar and flows southwest through northwestern Highland and eastern Dale townships. In sections 6 and 7 of Highland township, only a few miles from its head, this valley contains a gravel deposit with distinct benches 15 feet above the creek. Two gravel pits in these benches show seven to eight feet of fine gravel and sand, overlain by two to four feet of leached loesslike clay. The stream has cut through the gravel, exposing the till beneath. Benches are found farther down the valley through Dale township, as in the southwest corner of section 13 and at the northwest corner of section 26 .

Near Paullina in Union township the benches are 20 to 25 feet above Mill creek, and there are numerous exposures of gravel along the main valley and in the lower courses of tributaries. The gradient of Mill creek is greater than the slope of the terrace level and the elevation of the benches above the creek increases southward as shown in figure 23 .

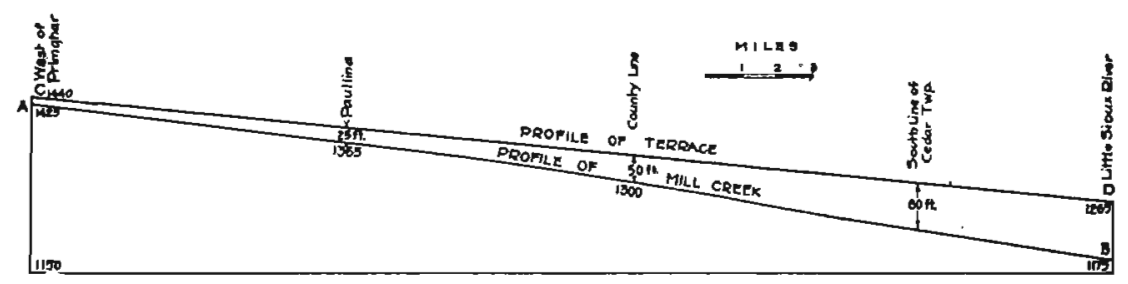

Fig. 23.-Profiles along Mill creek valley from central O'Brien county to its mouth showing, $A-B$, the gradient of the stream, and, C-D, the gradient of the terrace.

In section 28, Union township, there is a large exposure in a bench 40 to 45 feet above the stream. In part of the exposure the gravel apparently extends to the water level, but elsewhere it is underlain by about 10 feet of indefinite gray to brown silt or clay which rests on brownish yellow till, 
apparently Kansan. This clay material is probably the Loveland horizon. The gravel here is fresh fine gravel with much sand and is overlain by three to four feet of loesslike clay. On the south side of the. valley in the west part of section 34 the bench is about 50 feet above the creek (figure 23). The gravel horizon consists of 35 to 40 feet of fresh coarse sand with pebbles and cobbles scattered through it. It is overlain by four to six feet of loesslike clay and overlies till which rises six feet above the stream.

Willow and Nelson creeks head in Liberty township north of Calumet, flow westward into Union township, turn southward, unite, and join Mill creek just beyond the county line. Willow creek has a number of gravel hills along its slopes in Liberty township (pages 93 to 96), but it does not have a prominent valley-gravel deposit. Below the turn to the south in eastern Union township gravel benches are common along these creeks, especially in sections 25,26 and 36 . On the south line of section 24 a pit shows five feet of very fresh fine gravel, and a well on the bench along Nelson creek in the southwest quarter of section 23 penetrated 20 feet of sand and gravel. A low area connects Nelson creek valley in the west part of section 23 with Mill creek valley in the south part of section 15. It suggests an old water course, but the surface is undulating and does not appear to be underlain with gravel.

Farther south in Cherokee county the quantity of gravel material along Mill creek is larger, although the benches have small areal extent and are by no means continuous. The original width of the aggraded flat, as shown in figure 24, was about one mile, but much of this area has been cut out and is now in steep slopes or narrow flood plain. The altitude of the benches above the creek increases southward (figure 23), so that on the south line of Cedar township they are 75 to 80 feet above the creek and near the mouth of the valley they stand almost 100 feet above the stream. The creek winds back and forth from side to side of the valley, undercutting first one bank and then the other, and the gravel areas on the inner curves of the creek are found successively on alternate sides along the valley.

The Mill creek bench extends into the lower course of a tributary valley in the northeast quarter of section 10 and the east half of section 3 , Cherokee township, and from this valley a prong of the bench extends southeast across the northwest quarter of section 11 to the Little Sioux bench (figure 24). At the time of maximum aggradation this prong ${ }_{i}$ separated an area of upland in the southwest part of section 11 and the northwest part of section 14 from the upland to the north.

Minor Tributaries in Cherokee County.-In section 11, Spring township, in the northeast corner of Cherokee county, a small creek enters the 
Little Sioux from the east, and in the northwest quarter of section 12 there are benches along this valley 105 to 110 feet above the creek. The material exposed is relatively fresh sand with pebbles, has a thickness of

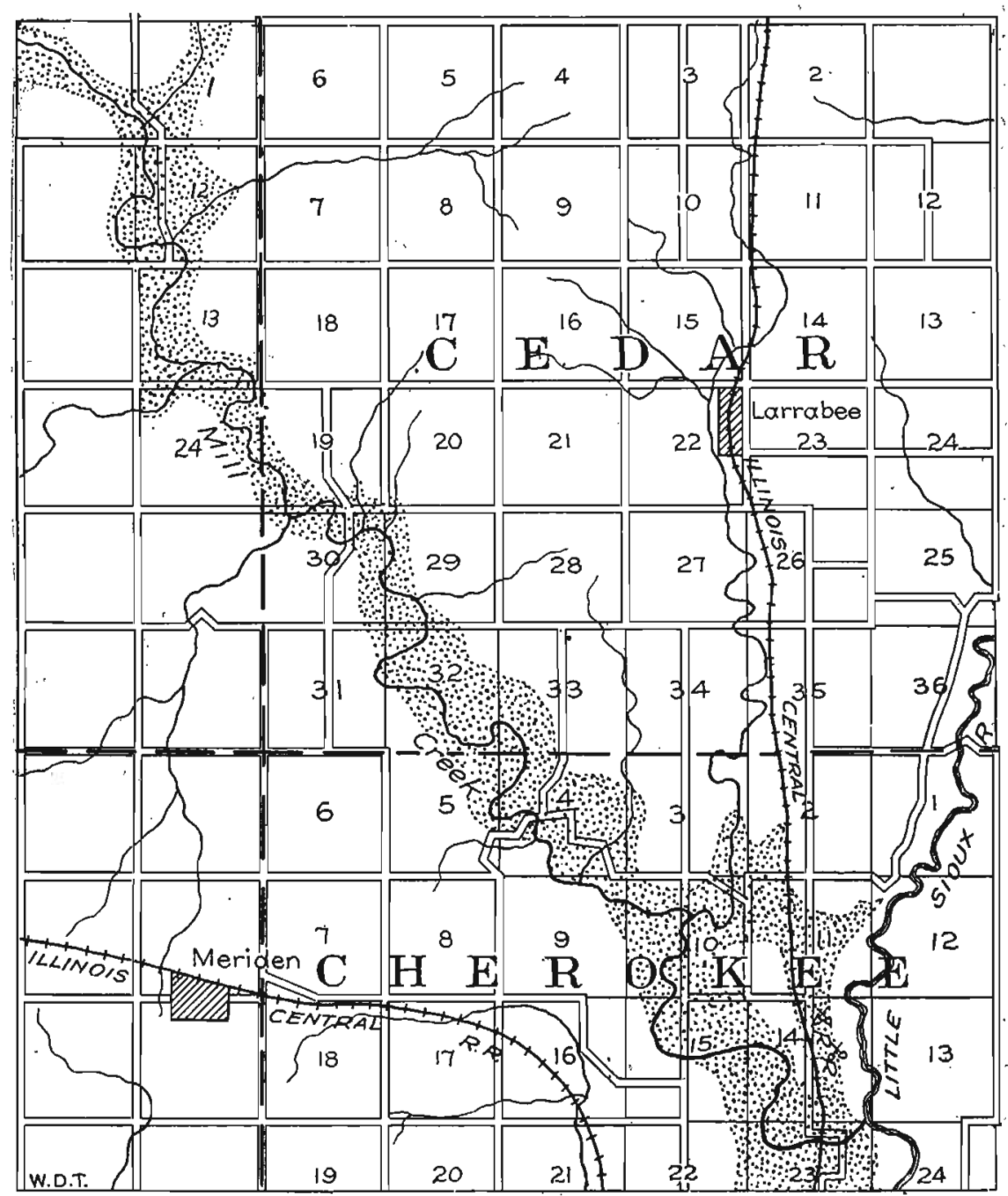

FIG. 24.-Map of a part of northern Cherokee county showing by the shaded area the original extent of the aggraded flat of Mill creek. Part of this area remains as terrace and part has been cut our and now exists as steep slopes or flood plain.

10 to 20 feet, and rests on till. A thin layer of gravel was seen on the slope of this valley near its head two miles farther east, in the northeast quarter of section. 7, Brooke township, Buena Vista county.

Most of the east half of section 16, Spring township, is a terrace 110 
feet above the Little Sioux, and a projection of this extends east up a valley through section 15 . The creek flowing southward through sections 18 and 19 of Spring township is bordered by benches 65 feet above the creek, and the gravel, which is 20 to 30 feet thick, rests on till. Gravel benches exist also along the valley in sections 24 and 25, Cedar township, especially in its lower part, where they become continuous with the bench of the Little Sioux valley. In Cherokee township there are gravel deposits in tributary valleys in sections 1 and 13.

In Pilot township two small creek valleys from the east contain notable gravel and silt deposits. One of these is in sections 10 and 11 and the other in the north parts of sections 22 and 23. The higher terrace of the Little Sioux valley continues into the lower end of the valley in section 10 and is represented in this valley by gravel benches almost to the township corner. In most of the exposures the material is clean fine gravel and quartz sand, but at some places deposits of silty sand and iron-stained silty material are present. In the lower part of the valley the gravel and silt deposit rests on Nebraskan till, but in the upper course of the valley it rests on Kansan till.

The higher bench of the Little Sioux valley also extends into the mouth of the tributary valley in the north part of section 22 and is marked by small benches on the valley sides eastward beyond the central line of section 23. At the mouth of the valley the terrace is 80 feet above the creek, but the gradient of the creek bed is so great that a mile east the benches are only 15 feet above the stream. In this distance the terrace rises 25 feet but the creek rises 90 feet. Where the valley crosses the quartersection line of section 23 the gravel rests on Kansan till, which in turn rests on Nebraskan till, but farther down the valley the Kansan till is absent and the valley-filling rests on the Nebraskan.

These two valleys of Pilot township are just outside the Iowan drift region but received Iowan drainage. Because of the bearing of the deposits. in the valleys on the question of the location of the Iowan boundary they were fully discussed on pages 72 to 77 .

All the tributaries of the Little Sioux from the west between Spencer and Cherokee and the minor tributaries from the east in northeastern Cherokee county drain the Iowan drift region, and the gravels are interpreted as outwash from the Iowan ice sheet, collected into the valleys which had been but slightly modified by the thin veneer of Iowan drift. In some places, as in the bluffs of Mill creek in section 14 of Cherokee township north of Cherokee (pages 84 to 87 ) and in the gravel pits of the same section (page 57), the 
gravels are interbedded with the till, showing an oscillation of the edge of the ice sheet during the time of gravel accumulation. Mill creek and Waterman creek furnish the greatest examples of gravel deposits in the Iowan drift region.

\section{Tributaries of the Little Sioux in the Kansan Drift Region}

Through Cherokee and Woodbury counties, outside the Iowan boundary, there are many small valleys, tributary to the Little Sioux, that have gravel in their lower courses. In general the benches of these valleys are continuous with those of the Little Sioux valley. In some cases the gravel may have been carried into the tributary valleys from the main valley, but in most cases it continues too far up the tributary valleys to have been derived in this way.

In Cherokee township there are gravel deposits in the valley from the northwest at Cherokee as far up as the central part of section 21 and in the valley which enters from the northwest just south of Cherokee. The higher bench of the Little Sioux valley continues into both of these valleys. These two small valleys are not far beyond the Iowan drift boundary as mapped, and there are some exposures in section 28 (page 129), suggesting that the Iowan ice sheet may have crossed Mill creek and occupied the central part of Cherokee township. Such an extension would account for the gravels of these two valleys as Iowan. However, there are other valley gravels in the Kansan region farther southwest which could not have been supplied by any possible extension of the Iowan region.

In the lower course of Parry creek, which drains the western part of Pilot township, there are a few benches high up on the slopes about 70 feet above the creek and about 35 feet above the lower terrace in the Little Sioux valley. Benches are found at intervals farther up the valley. Rock creek, which joins the Little Sioux north of the center of Willow township, also has along its lower course benches which are continuous with high, narrow benches along the Little Sioux valley to the north and south. These are present at intervals up the valley to the center of Rock township and decrease in altitude until they are only 15 feet above the creek.

Opposite Correctionville, in northeastern Woodbury county, the highlevel bench of the Little Sioux valley, 80 feet above the river, continues into the lower end of Pierson creek valley. A gravel pit in this bench at the northwest corner of section 34, Union township, at the mouth of the valley, showed 23 feet of fine-grained gravel and sand. The Walsh Brothers' pit near the center of the southeast quarter of section 28 , half a mile within the valley, showed 25 feet of gravel overlain by four feet of fine sand and 
above this about three feet of leached loess. An abandoned pit at the center of section 20, three miles within the valley, showed 10 feet of gravel over blue Kansan till and overlain by three to five feet of sand and sandy clay. Benches of gravel continue up the west branch of the creek to Pierson and are present in the lower course of the north branch. The material exposed in these pits is almost entirely clean quartz sand and fine gravel and is more worn than are the valley gravels farther north. Four analyses of pebbles from this valley show an average of 47 per cent igneous rocks, which is 10 per cent higher than the average of all valley gravels, and the sand averages about 95 per cent quartz grains. There are small snail shells in the gravel, and the pits in sections 34 and 28 have yielded some vertebrate remains (page 165 ).

The material overlying the gravel of the benches in the lower course of Pierson creek valley is not usually distinctive loess, but leached loess overlies the gravel at the Walsh pit and the sand and sandy clay of other exposures is undoubtedly the time equivalent of the loess. The stratigraphical position of the gravel below the loess is well shown on the north line of section 20 where a gully on the west slope of the north branch of the creek shows seven feet of loess, the upper three feet of which is leached, overlying 20 feet of gravel. The continuity of this gravel with that farther down the valley cannot be questioned, as this exposure is only half a mile from the pit exposure of section 20 .

These tributary valleys south of Cherokee are entirely in the Kansan drift region and such deposits as they contain must have been derived from the Kansan drift. The gravels and the benches of these valleys are continuous with those of the Little Sioux valley and apparently were deposited at the same time.

\section{Maple River Drainage Basin}

Maple river heads in northeastern Cherokee county and flows southward through eastern Cherokee and Ida counties to Ida Grove. Here it changes direction to southwest and holds this course to its union with the Little Sioux southeast of Onawa. In eastern Cherokee county this river has a broad upland valley with a large flat, much of which is overflowed by the river at times of high water. In northeastern Ida county the valley becomes deeper where it enters the more rugged part of the Kansan drift region and from here southward it is a broad, open valley more than 100 feet deep.

The broad valley of Maple river through eastern Cherokee county prob- 
ably is underlain with gravel material, but the river has only a shallow channel and gravel was seen at only a few places. In Galva township of northeastern Ida county, gravel was seen in benches at the northwest corner of section 10 and in sections 22, 27 and 34. The valley joining Maple river valley at Galva is bordered by gravel benches through the north part of section 23, and a pit just north of Galva shows 10 feet of clean gravel and sand overlain by five feet of yellow loesslike clay or leached loess.

At Ida Grove, Maple river is joined by Odebolt creek from the east. On the south side of the latter, in the west part of section 19, Blain township, there is an exposure of about 15 feet of sand with a few pebbles, and there is an abandoned gravel pit just northeast of the railway station at Ida Grove.

The headwaters of Maple river are entirely within the Iowan drift region and separated from the Wisconsin drift region by the high north-south divide of western Buena Vista county. No Wisconsin drainage could possibly have entered the valley. From section 20 , Pitcher township, Cherokee county, to Galva in northeastern Ida county, a distance of 13 miles, the Iowan boundary is mapped along the east side of Maple river. From Galva to Ida Grove the valley is out in the Kansan region, but its tributaries from the east head in the Iowan region. Southwest of Ida Grove the basin is entirely in the Kansan region. The gravels of the Maple river basin are, therefore, assigned to the Iowan outwash in large part. The gravels in some tributary valleys southwest of Ida Grove, which drain only the Kansan region, must have been derived from the Kansan.

\section{Boyer River Drainage Basin}

Boyer river heads southwest of Storm lake in southern Buena Vista county and flows east of south to southern Sac county. In this portion of its course it is four to six miles west of the Wisconsin drift margin and received drainage from the Wisconsin ice by a break through the divide to the east just north of the Buena Vista-Sac county line and by the Wall lake outlet south of the town of Wall Lake. From southern Sac county, Boyer river flows southwest across Crawford and Harrison counties to Missouri river.

The headwaters of Boyer river above Early occupy broad, upland valleys, characteristic of the Iowan drift region. Flat areas, that apparently are underlain with gravel, are found along the valleys of Eden township, but the streams have cut only shallow channels into them and exposures are 
few. In Boyer Valley and Clinton townships the valley is deeper. Gravel deposits were seen at a few places and may be of either Iowan or Wisconsin age. In southern Clinton and northern Levey townships, near the Iowan boundary, the valley contains gravel benches, probably of Iowan gravels.

The Wall lake outlet connects the Boyer valley with the Wisconsin plain and with a great gravel deposit of Wisconsin age at the west end of Wall lake. The bottom of the outlet is a swampy flat, projections of which extend up small tributaries of the Boyer into northwest Levey township.

Southwest of the Wall lake outlet, across Crawford county, the Boyer valley has steep slopes and a flat bottom which is at flood-plain level, and is in most places one-half to one mile wide. At a few places, especially at the mouths of tributary valleys, there are benches that look like remnants of a former valley filling.

In a recent report on the Geology of Crawford county, ${ }^{51}$ Doctor Lees shows that gravels have a wide distribution in the valleys of Crawford county (pp. 328-338 and map, p. 362). They are present on the lower slopes of the valleys where they at places form benches and they exist over the upper slopes at places even to the upland level. They are on the slopes of a topography which is cut into the Kansan drift and are overlain by the loess mantle. As in the region farther north, they are present both in the large valleys that cross the county and carried drainage from the Iowan drift region, such as the Boyer valley, and in many of the smaller valleys that head out on the divides of the Kansan region. Their presence in these smaller valleys which are entirely in the Kansan region far beyond the Iowan boundary gives further evidence that the valley gravels were in part derived by the erosion of the Kansan till, as discussed on pages 168 to 170 .

\section{FOSSILS FROM THE VALLEY GRAVELS}

The valley gravels, especially in the southern part of the area, have yielded some fossil remains. These include both vertebrates and mollusks.

The two deep pits just northeast of LeMars (pages 147 to 148) have yielded a number of bones. They were brought up by the dredge scoop and are said to come from different depths. Among the material from these pits are elephant tusks and teeth, part of a pelvic girdle of an elephant, deer horns, horse teeth and a number of unidentified

51 Iowa Geol. Survey, Vol. XXXII, pp. 241-362, 1927. 
leg bones and vertebræ. Remains, chiefly deer horns, limb bones and vertebræ have been obtained also from the Erdman pit in the Floyd river valley in the northwest part of LeMars (page 147) and from the pit operated by C. H. Grimes in Deep creek valley one mile east of Oyens (page 147).

From the pit of the Cherokee Sand and Gravel Company north of Cherokee a tooth of Elephas columbi, an elephant tusk, and various small bone fragments have been taken.

Two specimens obtained from the pit of the Walsh Brothers in Pierson creek valley west of Correctionville were identified by $\mathrm{Dr}$. O. P. Hay" as "a horn core and the base of a skull of a bison, both belonging to Bison occidentalis." The writer examined a large proboscidian tooth, a horn core, a horse tooth and some pieces of unidentified bones which were taken from the gravel pit of Paul Fleming, at the mouth of Pierson creek valley. A few miles south of Correctionville, within the Little Sioux valley, is the Gilleas gravel pit, from which a "buffalo head", deer horns, a worn tooth of Elephas primigenius and various bone fragments have been taken.

Some proboscidian bones have been found in the gravel deposit of Rock river at Rock Rapids. This locality is well out in the Kansan drift area, but the valley carried both Iowan and Wisconsin drainage.

The bones found in the gravels of northwestern Iowa are, so far as known, all isolated finds and many of the bones are worn. No complete skeletons have been found. The evidence is not such as to prove that the animals lived while the gravel was accumulating, although probably this was true.

Small snail shells were found in the gravel at several places in the southern part of the area, mostly in the tributary valleys of the Little Sioux at or near their union with the main valley. They were found in coarse sand and fine gravel as well as in silty sand and silt deposits.

In the creek valley in the northeast quarter of section 11 , Pilot township, Cherokee county, gastropod shells were found in fresh coarse sand in a railway cut. In the next creek valley to the south, in the northeast quarter of section 22 , small gastropod shells were found in a compact silt that forms part of the valley filling.

The gravel in the Paul Fleming pit at the mouth of Pierson creek, opposite Correctionville, contains many snail shells. At least five spe-

52 Iowa Geol. Survey, Vol. XXIII, p. 74, 1914. 
cies were collected here, although most of the shells belonged to one species.

South of our area, in Crawford county, shell-bearing gravels were found in two tributary valleys of the Boyer. Along Porter creek in Stockholm township, north of the village of Boyer, there is a gravel deposit which forms benches 30 to 40 feet above the creek, and snail shells were found at several places in the fresh sand and fine gravel in these benches. At the lower end of the valley just southwest of Boyer, mussel shells (unios) were found in a brownish yellow to bluegray silt zone. Farther south in the southwest part of section 6, Washington township, just above the mouth of the valley of Buck creek, which joins the Boyer near Arion, there is a bed of fresh, clean gravel which contains many gastropod shells. The zone is part of a 30-foot bank of sand and gravel which is overlain by fossiliferous loess.

All the gravels containing molluscan fossils and practically all those containing vertebrates lie outside the Iowan drift area. None of the gravels of the northern part of our area are fossiliferous. The deposits along Mill creek and elsewhere were examined carefully for fossils but none was found. South of Cherokee within two miles of the Iowan drift boundary fossiliferous gravels were found and at many places to the south. The gravels deposited by the waters flowing out from the Wisconsin ice sheet and the Iowan gravels deposited within the Iowan drift area evidently accumulated under conditions unfavorable for the gastropod fauna.

\section{ORIGIN AND AGE OF THE VALLEY GRAVELS}

The term valley gravels is intended particularly for those gravels which occupy valleys in the Iowan drift area and are of Iowan age. In those valleys of the Iowan area that head back into the Wisconsin drift region and which, therefore, carried drainage from the Wisconsin ice front, there may also be gravels of Wisconsin age, but it was not possible in most cases to distinguish the two types. Further, there are similar gravels in many valleys of the Kansan drift region which could not have been reached by drainage from the Iowan or the Wisconsin ice sheets and which, therefore, must have originated in some manner within the Kansan area. In the above discussion of the distribution of the gravels, all gravels occupying valleys have been treated, and in most of those cases in which valleys must have received drainage 
from two ice sheets it was not possible to differentiate the gravels of different ages.

In the Iowan drift region most of the gravels probably rest on Iowan till, although it is not as a rule possible to distinguish this till from the Kansan. In the valleys of the Kansan drift area the gravels rest on the Kansan till, except where the Kansan till had been entirely removed at the time of gravel deposition, as in the Little Sioux valley and the lower courses of some of its tributaries, in which case they rest on the Nebraskan till.

In composition the gravels are like those of the clay-ball hills (pages 90 to 102) and the inclosed gravel masses (pages 111 to 115) and closely resemble the pebbles that may be picked from the Iowan and Kansan tills. Clay-balls and shale pebbles are not common, as they are in the gravels of the gravel hills, indicating that the valley gravels were subjected to some transportation; and yet they were not transported far enough to wear out the limestones or to round the pebbles, most of which are subangular. Masses of Iowan till included in some of the gravel deposits, as in the gravel pits north of Cherokee (page 57), show that in these cases the Iowan ice was near. The composition is distinctly against an interglacial age.

The gravels of both the Iowan and the Kansan drift regions are generally overlain by pebbleless loesslike clay which is continuous with a similar deposit over the upland. In the west and southwest parts of the area studied, this deposit over the upland is the undoubted loess; and over the remainder of the Kansan drift and over the Iowan drift this deposit, although thinner and in many places leached for its entire thickness, is the time equivalent of the loess (page 120). The loesslike clay apparently was deposited soon after the gravels, for the top of the gravel deposit does not show the least indication of a weathered zone. In fact it appears that there was a transition from gravel deposition to deposition of loesslike clay, for there is at many places alternation of the two materials near the contact and a recurrence of sand and pebble bands in the lower 12 to 18 inches of the loesslike clay. The lower part of this loesslike clay shows banding in some exposures and must be water laid. The upper part must be eolian, a method of origin which would accord better with its texture and its general lack of bedding. The gravels apparently were deposited just before the formation of the Peorian loess. 
Most of these valley gravels of northwestern Iowa were interpreted as Wisconsin gravels by Macbride and Wilder. At first they were interpreted as being largely within the area of the Wisconsin drift, the boundary of that drift sheet being placed far enough southwest to include O'Brien county. Later, when the Wisconsin drift boundary was shifted to the Ocheyedan-Little Sioux course, the gravels of the extra-morainic region were interpreted as being due to waters which broke over the great divide and flooded the country to the southwest. With the margin located across Sac, Buena Vista, Clay, Dickinson and Osceola counties as described in the report of $1917,{ }^{63}$ it is possible to determine which streams could have received drainage from the Wisconsin ice. These are Big Sioux river; Rock river and its tributary, Little Rock river, with Otter creek; Little Sioux river and its tributary, Ocheyedan river, with the Little Ocheyedan; and Boyer river. The drainage courses of Floyd river, Mill creek, Waterman creek, Maple river and others which contain valley gravels could not have received Wisconsin drainage. Therefore, from the viewpoint of the possible distribution of Wisconsin outwash, the valley gravels could not all be of Wisconsin age.

The great bulk of the valley gravels are here interpreted as of Iowan age, deposited by the waters flowing out from the retreating Iowan ice front. The valleys had not been obliterated by the thin sheet of Iowan till (page 41) and from the beginning were stream courses and sites of deposition for the overloaded glacial waters. Where the waters passed beyond the Iowan drift area and deposited material in the valleys of the Kansan drift area the deposits occupy true erosion valleys and rest on either Kansan or Nebraskan till. This explanation applies to all the gravels in valleys that carried the drainage from the Iowan ice sheet.

The gravels in those valleys of the Kansan area that could not have received drainage from the Iowan ice sheet are more difficult to interpret. In general characteristics they are like those of the Iowan area and are overlain by the same loess deposit. Further, the benches formed by the gravels in those valleys of the Kansan area that did not carry lowan drainage connect exactly with the benches in the main valleys that did carry Iowan drainage and these latter benches continue up the main valleys into the Iowan area. It appears, therefore,

83 Iowa Geol. Survey, Vol. XXVI, pp. 255-293, 1917. 
that the valley gravels and the resulting benches of the Iowan and the Kansan regions are of the same age.

The only difference of any significance noted for the gravels in those valleys of the Kansan area that did not receive Iowan drainage is that they contain a somewhat larger percentage of the more resistant kinds of pebbles. Thirteen analyses of pebbles from benches in valleys that are entirely in the Kansan drift average 47 per cent igneous rocks, while 42 analyses of pebbles from the valley gravels of the Iowan drift area average only 27 per cent igneous. There is also a larger percentage of the resistant types of sedimentary rocks in the analyses from the Kansan drift region, where quartzites average 7 per cent and cherts 4 per cent, while in the analyses from the Iowan drift area each of these types averages only 1 per cent. The sand likewise contains only the more resistant material, about 95 per cent of it being quartz grains. This all shows a greater amount of transportation and wear for this gravel of the Kansan region.

It is believed that this gravel, in valleys of the Kansan region that were not reached by drainage from the Iowan ice sheet, was derived from the Kansan till, from which it was released by erosion, and that it collected in the valleys as the finer material was carried beyond the region. The conditions under which fresh, unleached gravels would accumulate so widely in erosional valleys are not well understood. They may be climatic and associated with the decreased vegetation and increased erosion of the Iowan ice age, during which, although the ice did not actually cover the region, its climatic effects were strongly felt. This would explain the agreement of bench levels and the continuity of the gravels and overlying loess of the two types of gravels, which indicate that they were being accumulated at the same time. That is, the gravels released by erosion of Kansan till were being deposited in the tributary valleys while the main valleys were being aggraded by Iowan outwash. Of course, if this origin is applicable for those gravels of the valleys of the Kansan region which were not reached by the Iowan drainage, the same origin must hold for some of the gravels in those main valleys of the Kansan region which also carried Iowan drainage.

By this interpretation the accumulation of the gravels came after the uplift of the postulated gumbotil plain and after its erosion to a stage which had removed all remnants of the gumbotil and leached zones. 
In the valleys there then accumulated the valley gravels. No leaching of the underlying till took place before the gravels were deposited and no leaching of the gravels took place before the deposition of the overlying loess. The gravels were derived largely from unleached materials and accumulated relatively rapidly, for they are not leached, as is commonly true of gravels that accumulate slowly during an interglacial age. If these gravels were derived from the Kansan till by erosion and removal of the finer material as here outlined, they are remarkably fresh and unaltered for such an origin, since they cannot be distinguished from those of the Iowan region which are interpreted as outwash gravels. Perhaps this gravel accumulation was an incident of the declining stage of a period of more rapid, active erosion of the Kansan region during the Iowan ice age. 
CHAPTER VI

\section{ANALYSES OF PEBBLES}

During the progress of the work in northwestern Iowa about 200 analyses of pebbles from the several types of gravels were made. The method followed was to count out 100 pebbles just as they came from the gravel, taking all those above one-fourth inch and under two inches in diameter. These were then classified according to certain selected rock types and the percentages of the several types determined, as shown in the following tables.

These analyses were made with the hope that a composition basis might be found for the separation of the several types of gravels, but the analyses from these several types are so similar that they cannot be used for this purpose. The variations within one type are commonly greater than the differences between the averages for the several types. There are, however, a few distinctive characteristics, such as the presence of clay-balls in the gravels of the gravel hills, which can be used with a fair degree of accuracy in the differentiation of certain types of gravels. The study was, on the whole, so inconclusive that the data were not included in the report of 1917 . The tabulated analyses are here presented for what value they may have. They should be of some assistance to anyone who contemplates a similar study in this region or elsewhere.

\section{Tables of Analyses of Pebbles}

For convenience of comparison the analyses of the several types are brought together here in one section rather than distributed through the report where the several types of gravels are described and interpreted. In the tables which follow, the analyses are grouped according to type of deposit, but a few of the placings are somewhat questionable. A number of the analyses made are not included in the tables because they could not be definitely placed in one of the several types of deposits indicated by the headings of the several tables.

One hundred sixty-two analyses of pebbles are here tabulated. They are grouped in eight tables which represent eight more or less definite types of gravels. The last column of each table gives the average for 
TABLE I

Analyses of Pebbles from Till or Gravel within the Wisconsin Region

\begin{tabular}{|c|c|c|c|c|c|c|c|c|c|c|c|c|c|c|c|c|}
\hline & 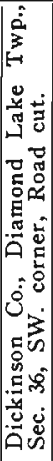 & 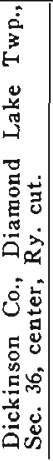 & 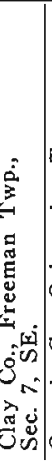 & 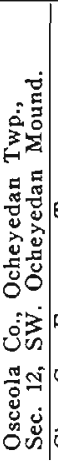 & 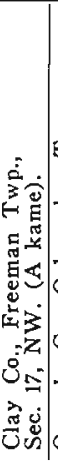 & 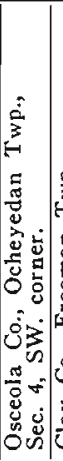 & 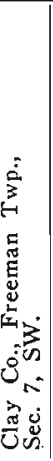 & 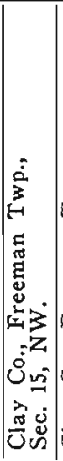 & 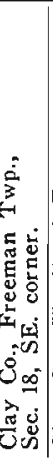 & 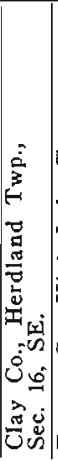 & 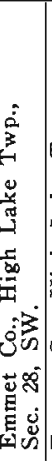 & 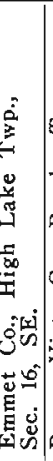 & 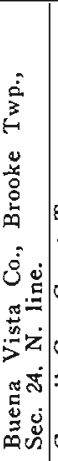 & 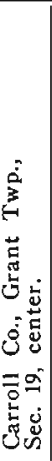 & 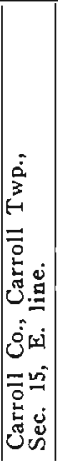 & 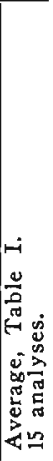 \\
\hline ira & 13 & 14 & 13 & 24 & 26 & 28 & 17 & 19 & 26 & 20 & 14 & 27 & 18 & 23 & 19 & 20 \\
\hline abbro & 2 & 2 & & 8 & - & 3 & 2 & 3 & 2 & & & 1 & 6 & 1 & & 2 \\
\hline Basal & 10 & 5 & 12 & 16 & 5 & 6 & 9 & 14 & 6 & 12 & 15 & 3 & 4. & 6 & & 9 \\
\hline Quartz & 2 & 1 & 3 & 1 & 1 & 2 & 2 & -- & 1 & - & 3 & 4 & 3 & 1 & & 2 \\
\hline el. igneous & 2 & 4 & 4 & 2 & & 2 & 1 & -- & -- & 2 & -- & -- & 3 & & 15 & 2 \\
\hline igneou & 29 & 26 & 32 & 51 & 32 & 41 & 31 & 36 & 35 & 34 & 32 & 35 & 34 & 31 & 45 & 35 \\
\hline & 3 & 3 & 10 & -- & 4 & - & 4 & 2 & 6 & - & -_ & -- & 3 & 1 & 2 & 3 \\
\hline Che & 1 & 2 & -- & _- & 1. & 2 & 1 & 3 & 1 & -- & -- & 3 & 1 & 1 & 1 & 1 \\
\hline dolo- & & & & & & & & & & & & & & & & \\
\hline & 66 & 60 & 55 & 47 & 59 & 50 & 54 & 57 & 57 & 45 & 64 & 57 & 61 & 58 & 40 & 55 \\
\hline & -- & 9 & --1 & $\ldots$ & 1 & & -- & 2 & -- & 1 & -- & 1 & 1 & & & 2 \\
\hline & 1 & -- & 3 & -- & -- & -- & - & -- & -- & & -- & -- & -- & & & \\
\hline Clay & -- & -- & -- & -- & -- & - & 9 & -- & -- & 17 & -- & -- & -- & 1 & 3 & 2 \\
\hline Mis & . & 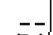 & $\ldots$ & 2 & 3 & -2 & 1 & 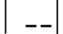 & 1 & 3 & 4 & 4 & -- & 3 & 3 & 2 \\
\hline Cotal sedim & 71 & $74 \mid$ & 68 & 49 & 68 & 59 & 69 & 64 & 65 & $66 \mid$ & 68 & 65 & 66 & 69 & $|55|$ & 65 \\
\hline
\end{tabular}

the analyses of that table, using the nearest unit number. Table IX presents a summary of the averages of the eight types represented by the eight tables.

The several rock types selected for the classification are quite general divisions and the determinations were made in the field from the freshly broken pebbles. The granite-syenite division is almost entirely granite but might include any light-colored coarse-grained igneous rock. Likewise the diorite-gabbro division might include any darkcolored fine-grained igneous rocks. The light-colored fine-grained igneous rocks are very rare and are included in the miscellaneous igneous. The quartz pebbles are included in the total igneous. Only an occasional pebble of gneiss or schist was found and these are included with the miscellaneous igneous. The quartzite pebbles are included in the total sedimentary.

The gravels of northwestern Iowa are, in general, quite fresh and unaltered. This is, of course, in keeping with the general freshness of 
TABLE II

Analyses of Pebbles from Valley Gravels of the Wisconsin Region

\begin{tabular}{|c|c|c|c|c|c|c|c|c|c|c|c|}
\hline & 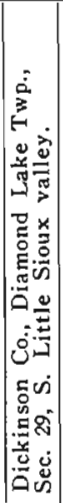 & 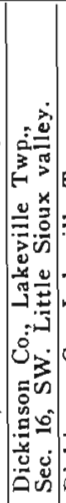 & 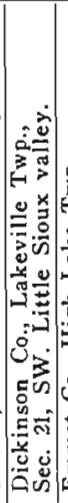 & 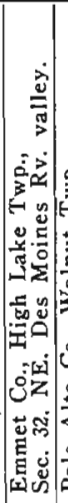 & 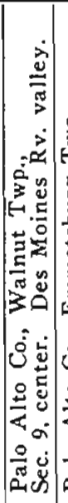 & 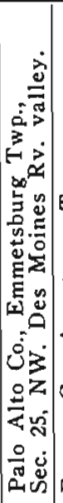 & 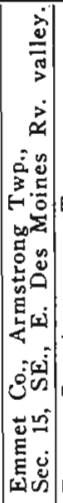 & 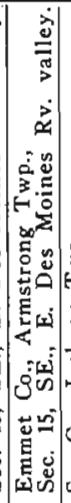 & 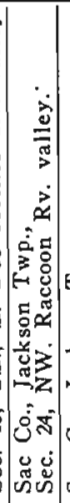 & 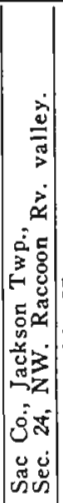 & 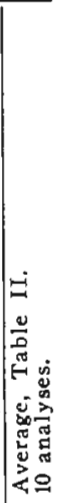 \\
\hline Granite-syenite - & 25 & 31 & 23 & 14 & 29 & 23 & 20 & 27 & 37 & 31 & 26 \\
\hline Diorite-gabbro & 2 & 1 & --1 & & 1 & 4 & & 1 & 2 & & \\
\hline Basalt & 11 & -- & 8 & 11 & 13 & 8 & 5 & 4 & 5 & 6 & \\
\hline Quartz -- & -- & 2 & 2 & 1 & -- & 1 & i & 1 & & & \\
\hline Miscel: igneous & 1 & 2 & & 1 & 1 & 1 & -- & -- & 2 & 2 & \\
\hline Total igneous & 39 & 36 & 33 & 27 & 44 & 37 & 26 & 33 & 46 & 39 & 36 \\
\hline artzite & 6 & 1 & 2 & 5 & 8 & 5 & -- & -- & 3 & 1 & \\
\hline Chert and flint & & 1 & & & & 3 & 1 & & & & \\
\hline Limestone and dolomite & 55 & 58 & 65 & 65 & 46 & 53 & 52 & 59 & 50 & 53 & $5 \overline{5}$ \\
\hline Shale & -- & 4 & -- & -- & -- & - & 19 & 2 & 1 & 6 & \\
\hline & & -- & -- & - & -- & 1 & 2 & 1 & - & 1 & \\
\hline 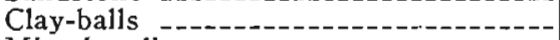 & --1 & -- & -- & -- & & & -- & & - & -. & \\
\hline imentary & & -- & & 3 & 2 & 1 & -_ & 5 & & - & \\
\hline Total sedimentary & 61 & | $64 \mid$ & 67 & 73 & 56 & 63 & 74 & 67 & 54 & 61 & 64 \\
\hline
\end{tabular}

the tills. In practically all the analyses limestone and dolomite dominate, being about one-half of the whole, and are almost entirely gray compact stone. Other types of sedimentary rocks are not common, sandstone and shale being almost negligible. The second most abundant type is granite, which constitutes about one-fourth of the whole and is dominantly pink in color. Basalt, including greenstone, commonly forms about 10 per cent, and other igneous rocks are not common.

Table I gives the analyses of pebbles from till or gravel within the Wisconsin region. The first three analyses of this table are of pebbles taken directly from the Wisconsin till; the remainder are of pebbles from gravel deposits associated with the till but do not include gravels in valleys. Table II records the analyses from gravels in valleys of the Wisconsin region, and Table III includes the analyses from gravels of probable Wisconsin age in valleys beyond the Wisconsin boundary. Tables I, II and III include all the analyses of grav- 


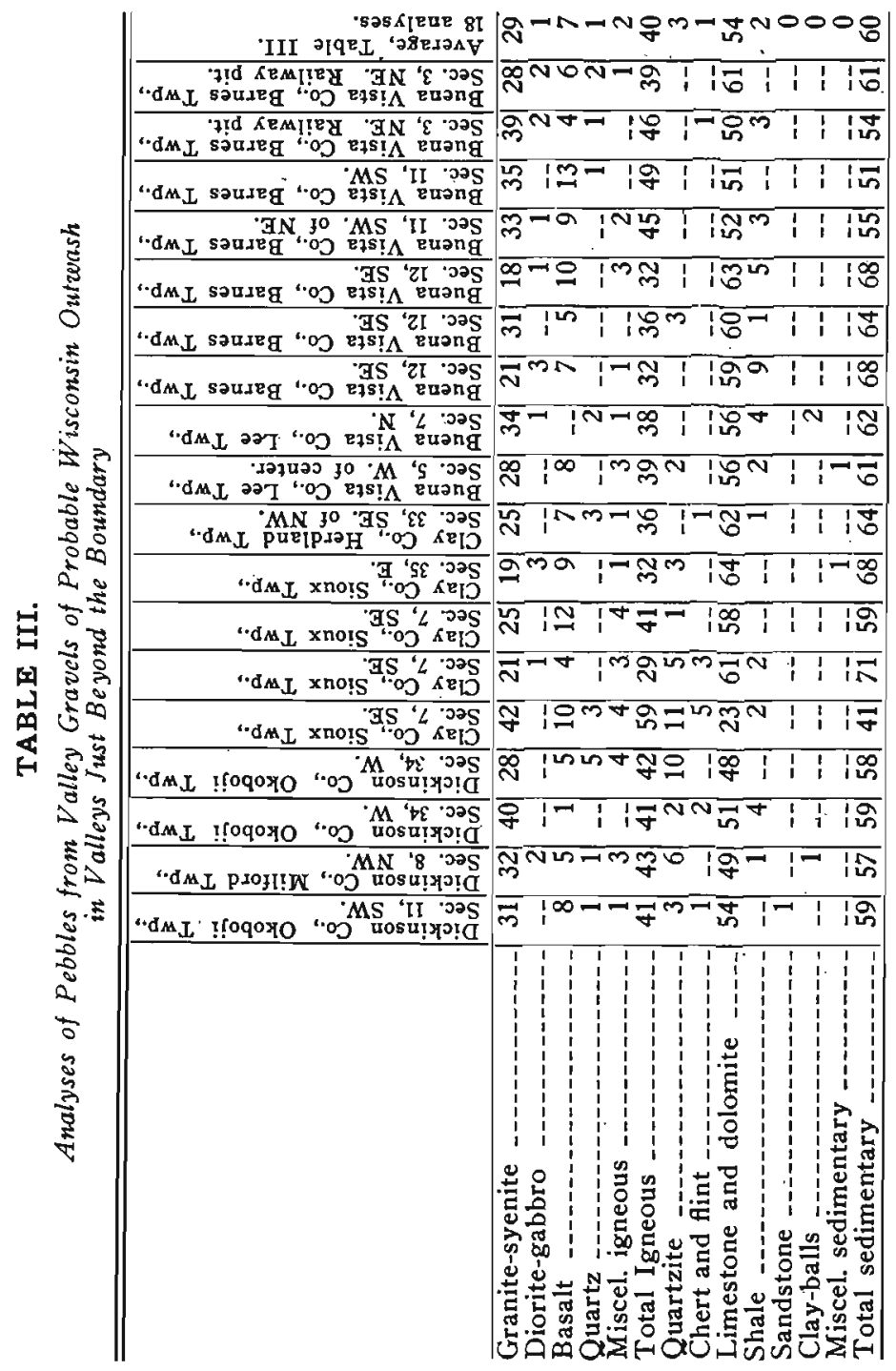

els interpreted as Wisconsin in age. The average of the 43 analyses of these three tables is given in column $3 a$ of Table IX. It shows no distinctive differences from the gravels of the Iowan or Kansan regions.

Table IV gives the analyses of the pebbles from the gravel hills of the Iowan region. This type of gravel has a distinguishing characteristic in the abundance of clay-balls or small rounded masses of till. 


\section{TABLE IV}

Analyses of Pebbles from the Gravel Hills of the lowan Region

\begin{tabular}{|c|c|c|c|c|c|c|c|c|c|c|c|c|c|c|c|c|c|c|c|c|c|}
\hline & 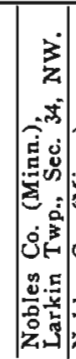 & 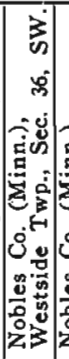 & 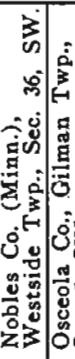 & 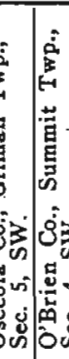 & 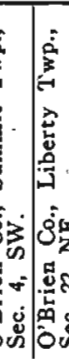 & 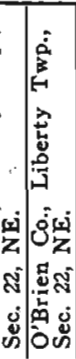 & $\mid$ & 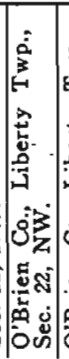 & 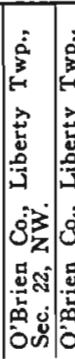 & 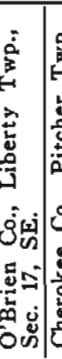 & 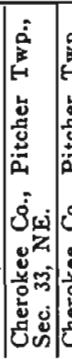 & 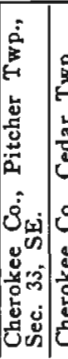 & 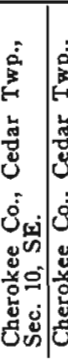 & 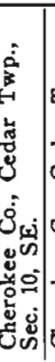 & & 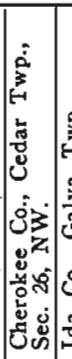 & 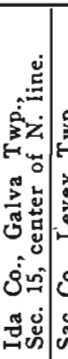 & & & & \\
\hline $\begin{array}{l}\text { ranite-syenite } \\
\text { iorite-gabbro } \\
\text { asalt }\end{array}$ & \begin{tabular}{|r|}
22 \\
-- \\
3 \\
-- \\
$-\overline{25}$ \\
$-\overline{1}$ \\
65 \\
7 \\
$-\overline{2}$
\end{tabular} & \begin{tabular}{|r|}
13 \\
1 \\
8 \\
$-\overline{1}$ \\
23 \\
-2 \\
58 \\
58 \\
-- \\
-16 \\
1 \\
77
\end{tabular} & \begin{tabular}{r|r}
20 & 1 \\
1 & 5 \\
1 & - \\
27 & 1 \\
-- & - \\
64 & 4 \\
5 & 4 \\
-3 & 2 \\
1 & 2 \\
73 & 8
\end{tabular} & \begin{tabular}{r|r}
16 & 1 \\
2 & \\
1 & - \\
\hdashline-3 & - \\
19 & 2
\end{tabular} & \begin{tabular}{r|r}
13 & 1 \\
3 & \\
-5 & - \\
22 & 2
\end{tabular} & 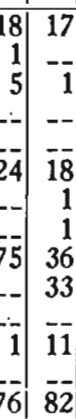 & $\left|\begin{array}{r}15 \\
-2 \\
-2 \\
-17 \\
1 \\
1 \\
43 \\
19 \\
-19 \\
19\end{array}\right|$ & $\mid$\begin{tabular}{r|}
23 \\
-2 \\
-1 \\
26 \\
-2 \\
55 \\
- \\
16 \\
1 \\
74
\end{tabular} & \begin{tabular}{|r|}
18 \\
-1 \\
1 \\
-- \\
$\overline{19}$ \\
-- \\
$\overline{53}$ \\
2 \\
$-\overline{2}$ \\
$\overline{26}$ \\
$\overline{81}$
\end{tabular} & \begin{tabular}{r|r|}
7 \\
$-\overline{1}$ \\
-- \\
$-\overline{8}$ \\
-- \\
29 \\
4 \\
59 \\
5 \\
92
\end{tabular} & \begin{tabular}{|r|}
30 \\
-12 \\
4 \\
2 \\
48 \\
7 \\
2 \\
39 \\
-- \\
-- \\
-4 \\
52 \\
\end{tabular} & \begin{tabular}{|r|}
22 \\
8 \\
13 \\
4 \\
1 \\
48 \\
5 \\
2 \\
43 \\
-- \\
-2 \\
-52 \\
52
\end{tabular} & \begin{tabular}{|r|r|}
23 \\
1 \\
6 \\
1 \\
-31 \\
2 \\
4 \\
46 \\
2 \\
2 \\
-4 \\
1 \\
69
\end{tabular} & \begin{tabular}{r|}
18 \\
1 \\
3 \\
1 \\
$-\overline{3}$ \\
1 \\
$\frac{1}{2}$ \\
65 \\
6 \\
$-\overline{2}$ \\
1 \\
77
\end{tabular} & \begin{tabular}{|c|}
19 \\
-- \\
$\overline{43}$ \\
15 \\
$\overline{23}$ \\
$\overline{81}$ \\
\end{tabular} & \begin{tabular}{|r|}
15 \\
-3 \\
-3 \\
-18 \\
1 \\
52 \\
11 \\
-12 \\
6 \\
82
\end{tabular} & \begin{tabular}{|r|}
25 \\
5 \\
11 \\
4 \\
1 \\
46 \\
7 \\
3 \\
37 \\
-- \\
-3 \\
4 \\
54
\end{tabular} & \begin{tabular}{|r|}
21 \\
-3 \\
1 \\
1 \\
26 \\
2 \\
-71 \\
1 \\
--- \\
-- \\
74
\end{tabular} & \begin{tabular}{r|}
8 \\
1 \\
3 \\
-- \\
-12 \\
3 \\
-80 \\
-- \\
-1 \\
4 \\
48
\end{tabular} & \begin{tabular}{r|}
7 \\
2 \\
4 \\
-- \\
-3 \\
13 \\
3 \\
1 \\
80 \\
-- \\
-- \\
1 \\
2 \\
87
\end{tabular} & \\
\hline
\end{tabular}


TABLE V, SHEET 1

Analyses of Pebbles from Valley Gravels of the Iowan Region

\begin{tabular}{|c|c|c|c|c|c|c|c|c|c|c|c|c|c|c|c|c|c|c|}
\hline & 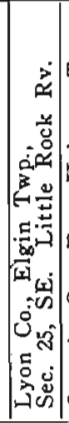 & 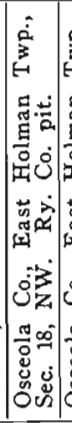 & & & & & & 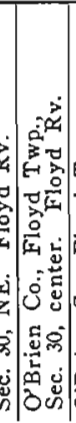 & 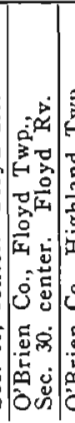 & 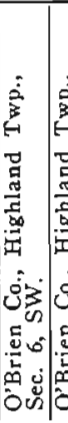 & 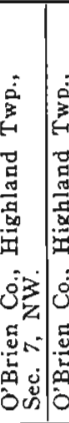 & & 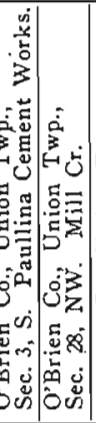 & 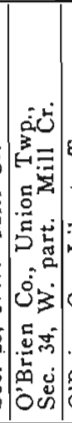 & & 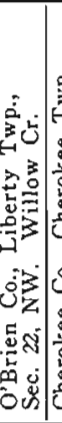 & 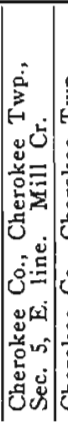 & 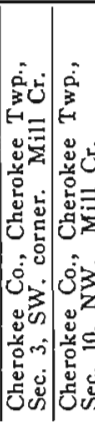 \\
\hline $\begin{array}{l}\text { uartzite } \\
\text { hert and flint } \\
\text { imestone and dolomite } \\
\text { hale } \\
\text { andstone } \\
\text { lay-balls } \\
\text { Iiscel. sedimentary } \\
\text { otal sedimentary }\end{array}$ & $\begin{array}{r}14 \\
3 \\
4 \\
1 \\
--2 \\
2 \\
-- \\
\overline{7} \\
-- \\
-- \\
--\end{array}$ & \begin{tabular}{|r|}
24 \\
1 \\
4 \\
-- \\
$-\overline{29}$ \\
$i$ \\
-3 \\
66 \\
6 \\
2 \\
$-\therefore$ \\
$-\because$ \\
71
\end{tabular} & $\begin{array}{r}-\overline{6} \\
-1 \\
24 \\
--3 \\
73 \\
--- \\
---\end{array}$ & 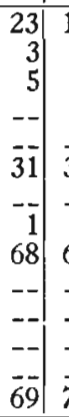 & \begin{tabular}{r|r}
9 \\
1 \\
-30 \\
1 \\
69 \\
-3 \\
-7 \\
-
\end{tabular} & 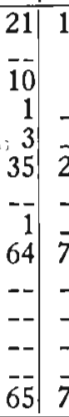 & \begin{tabular}{r|r}
16 & 23 \\
1 & 1 \\
8 & 10 \\
-- & 2 \\
25 & 36 \\
- & 1 \\
55 & 62 \\
\hdashline- & - \\
-- &
\end{tabular} & $\begin{array}{rr}3 & 14 \\
1 & 1 \\
0 & 4 \\
2 & 1 \\
6 & 2 \\
6 & 22 \\
1 & -2 \\
2 & 75 \\
- & 1 \\
- & --\end{array}$ & \begin{tabular}{|r|}
13 \\
1 \\
6 \\
- \\
4 \\
24 \\
-- \\
68 \\
8 \\
-- \\
-- \\
76
\end{tabular} & \begin{tabular}{r|}
24 \\
-- \\
2 \\
2 \\
--8 \\
1 \\
-- \\
71 \\
-- \\
-- \\
-- \\
$\overline{72}$
\end{tabular} & \begin{tabular}{r|r|}
15 & 2 \\
5 & 1 \\
--3 & \\
--1 & 1 \\
75 & \\
-- \\
-- \\
-1 \\
77
\end{tabular} & \begin{tabular}{r|l}
19 & 1 \\
1 & \\
5 & 1 \\
1 & - \\
26 & $\overline{3}$ \\
-1 & - \\
72 & 5 \\
1 & - \\
-- & - \\
-- & - \\
74 & 6
\end{tabular} & \begin{tabular}{r|r}
19 & 16 \\
2 & $-\overline{1}$ \\
16 & 8 \\
-- & 3 \\
$\overline{37}$ & $-\overline{27}$ \\
--2 & 2 \\
59 & -69 \\
-- & $-\overline{1}$ \\
-- & 1 \\
-2 & -1 \\
63 & 73
\end{tabular} & $\left|\begin{array}{r}14 \\
3 \\
4 \\
2 \\
1 \\
24 \\
7 \\
2 \\
59 \\
2 \\
5 \\
- \\
-1 \\
76\end{array}\right|$ & \begin{tabular}{|r|}
17 \\
$-\overline{7}$ \\
1 \\
$\overline{2} \overline{5}$ \\
-- \\
$\overline{7} \overline{5}$ \\
-- \\
-- \\
-- \\
$\overline{7} \overline{5}$
\end{tabular} & \begin{tabular}{r|r}
$-\overline{4}$ \\
1 \\
$\overline{2} \overline{2}$ \\
1 \\
$\overline{77}$ \\
-- \\
- \\
-- \\
$\overline{7} \overline{8}$
\end{tabular} & \begin{tabular}{|r|}
14 \\
4 \\
18 \\
3 \\
1 \\
40 \\
6 \\
1 \\
53 \\
-- \\
-- \\
-- \\
-60
\end{tabular} & \begin{tabular}{r|r}
13 & 1 \\
-5 & 1 \\
1 & \\
-19 & 3 \\
2 & 3 \\
78 & 6 \\
-2 & - \\
-0 & \\
-11 & - \\
81 & 6
\end{tabular} \\
\hline
\end{tabular}


TABLE V, SHEET 2

Analyses of Pebbles from Valley Gravels of the Iowan Region

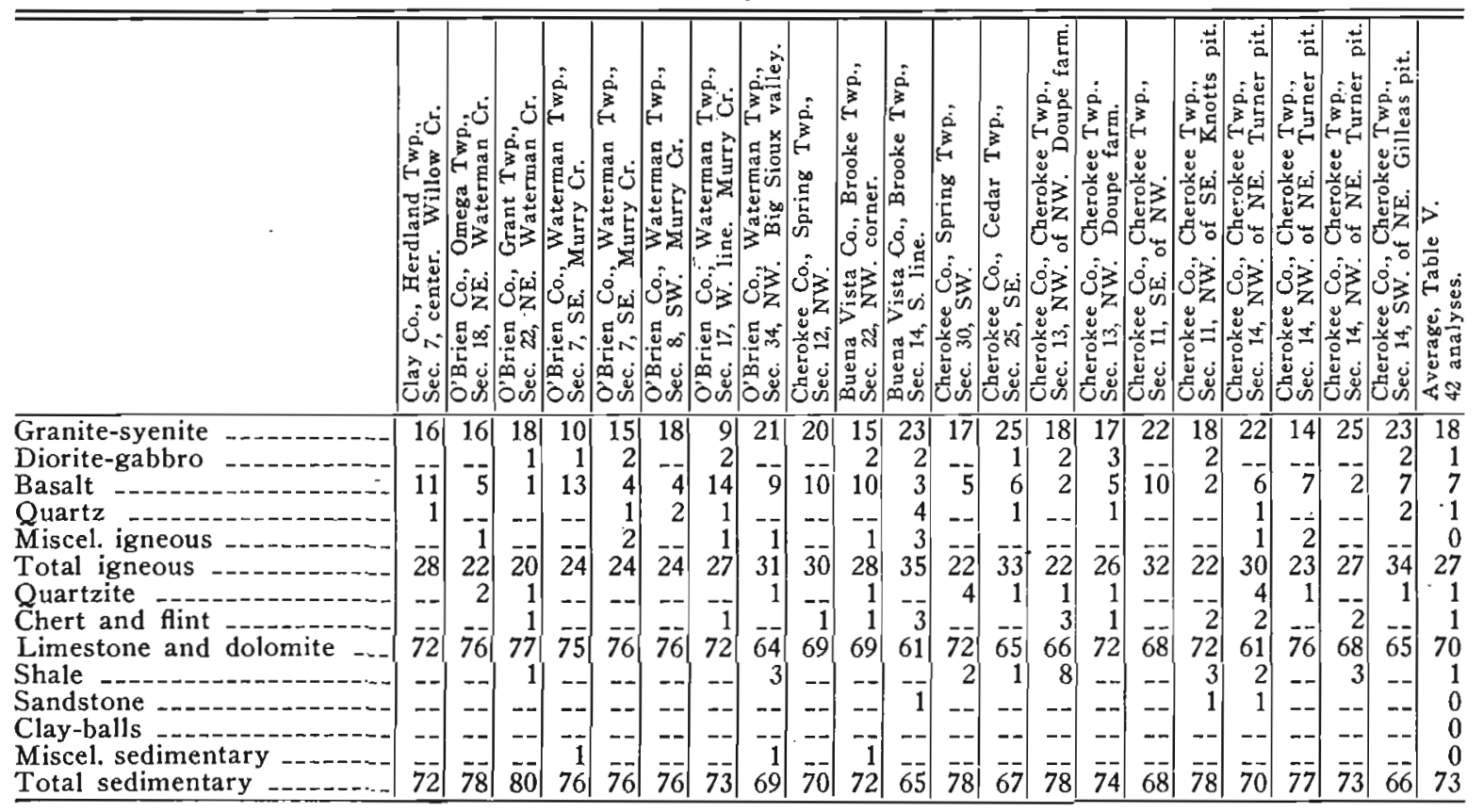


TABLE VI, SHEET 1

Analyses of Pebbles from Valley Gravels in Iowan Drainage Lines of the Kansan Region

\begin{tabular}{|c|c|c|c|c|c|c|c|c|c|c|c|c|c|c|c|}
\hline & 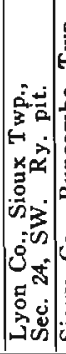 & & & & & 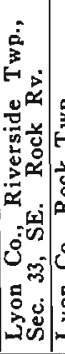 & & $\mid$ & 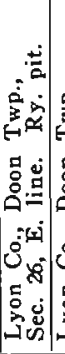 & 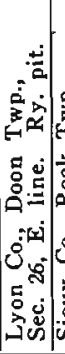 & 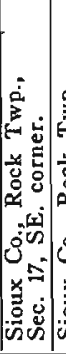 & 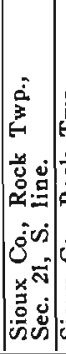 & 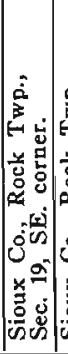 & 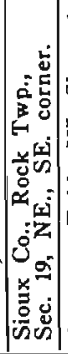 & 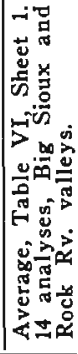 \\
\hline $\begin{array}{l}\text { Granite-syenite } \\
\text { Diorite-gabbro } \\
\text { Basalt } \\
\text { Quartz } \\
\text { Miscel. igneous } \\
\text { Total igneous } \\
\text { Quartzite } \\
\text { Chert and fint } \\
\text { Limestone and dolomite } \\
\text { Shale } \\
\text { Sandstone } \\
\text { Clay-balls } \\
\text { Miscel. sedimentary -- } \\
\text { Total sedimentary }\end{array}$ & $\mid \begin{array}{r}21 \\
2 \\
8 \\
2 \\
-33 \\
7 \\
3 \\
57 \\
-- \\
-- \\
-- \\
67\end{array}$ & \begin{tabular}{r|}
39 \\
2 \\
19 \\
1 \\
3 \\
64 \\
2 \\
2 \\
32 \\
-- \\
-- \\
-- \\
-36
\end{tabular} & \begin{tabular}{r|}
35 \\
13 \\
1 \\
49 \\
3 \\
2 \\
46 \\
-- \\
- \\
--
\end{tabular} & \begin{tabular}{r|}
$23 j$ \\
4 \\
15 \\
1 \\
1 \\
44 \\
5 \\
3 \\
48 \\
- \\
-- \\
-- \\
56
\end{tabular} & \begin{tabular}{r|}
30 \\
2 \\
13 \\
-- \\
$\overline{45}$ \\
2 \\
$\overline{5}$ \\
-- \\
-- \\
-- \\
$\overline{5}$ \\
5
\end{tabular} & \begin{tabular}{|r|}
32 \\
2 \\
6 \\
1 \\
2 \\
43 \\
3 \\
1 \\
53 \\
-- \\
-- \\
-2 \\
57 \\
\end{tabular} & \begin{tabular}{r|r|}
34 & - \\
3 & 1 \\
$3-$ & \\
4 & 3 \\
55 & - \\
-- & - \\
62 &
\end{tabular} & \begin{tabular}{r|r|}
22 \\
7 \\
8 \\
2 \\
4 \\
43 \\
8 \\
$-\overline{45}$ \\
$-\overline{2}$ \\
-2 \\
5 \\
57
\end{tabular} & \begin{tabular}{|r|}
33 \\
5 \\
6 \\
2 \\
2 \\
48 \\
2 \\
3 \\
47 \\
-- \\
-- \\
-- \\
52
\end{tabular} & $\begin{array}{r}34 \\
5 \\
4 \\
- \\
1 \\
44 \\
8 \\
2 \\
46 \\
-- \\
-- \\
- \\
56\end{array}$ & \begin{tabular}{r|}
42 \\
2 \\
12 \\
- \\
1 \\
57 \\
1 \\
1 \\
38 \\
- \\
1 \\
-2 \\
43 \\
\end{tabular} & $\left|\begin{array}{r|}31 \\
-18 \\
3 \\
1 \\
53 \\
4 \\
2 \\
41 \\
--- \\
-- \\
-- \\
7\end{array}\right|$ & $\mid \begin{array}{r}32 \\
4 \\
13 \\
-- \\
-49 \\
6 \\
-\overline{45} \\
-- \\
-- \\
-- \\
51\end{array}$ & $\mid \begin{array}{r}39 \\
5 \\
4 \\
4 \\
1 \\
53 \\
7 \\
-40 \\
--- \\
-- \\
-4 \overline{40} \\
- \\
- \\
-\end{array}$ & $\begin{array}{r}32 \\
3 \\
10 \\
1 \\
1 \\
47 \\
5 \\
2 \\
46 \\
0 \\
0 \\
0 \\
0 \\
53\end{array}$ \\
\hline
\end{tabular}

Their presence indicates that this gravel was not transported far by running water. These clay-balls are present in 19 of the 21 analyses of Table IV and average 12 per cent for the 21 analyses. One analysis shows 59 per cent of clay-balls. The presence of the clay-balls cuts down the percentages of other types of pebbles, so that granites, and igneous rocks as a whole, show lower percentages than in the other types (Table IX, column 4). Table $\mathrm{V}$ records the analyses from valley gravels of the Iowan region and Table VI the analyses from valley gravels in Iowan drainage lines of the Kansan region. These two types do not contain clay-balls. Tables IV, V and VI include all the gravels interpreted as Iowan in age. The average of the 96 analyses of these three tables is given in column 6a of Table IX. It is low in granite and total igneous and high in limestone, clay-balls and total sedimentary, but the differences are not such as can be used to differentiate Iowan gravels.

Table VII shows the analyses of valley gravels which are believed to have been derived from Kansan till, and Table VIII shows analyses of gravels inclosed in, or associated with Kansan till. The average 
TABLE VI, SHEET 2

Analyses of Pebbles from Valley Gravels in Iowan Drainage Lines of the Kansan Region

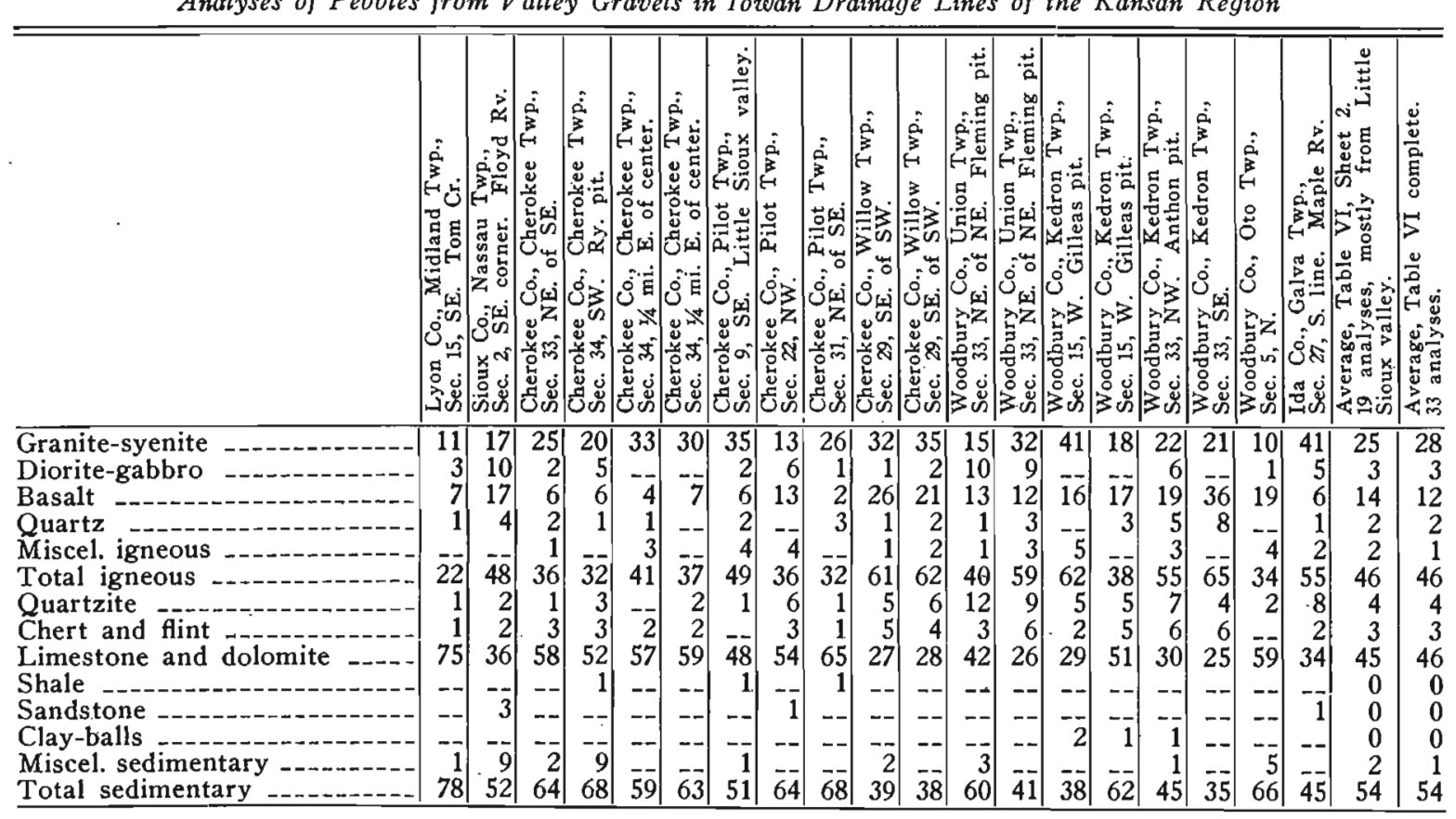


TABLE VII

Analyses of Pebbles from Valley Gravels of the Kansan Region in Drainage Lines Not Reached by Iowan or Wisconsin Drainage

\begin{tabular}{|c|c|c|c|c|c|c|c|c|c|c|c|c|c|c|}
\hline & 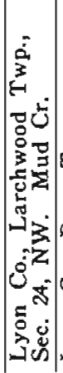 & 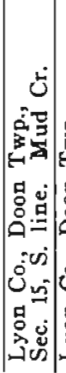 & 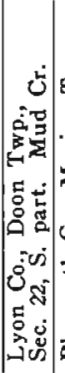 & 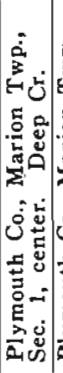 & 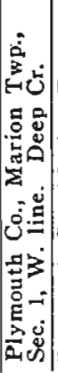 & 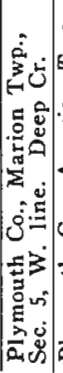 & 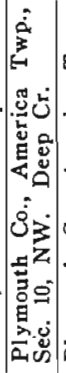 & 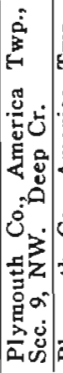 & 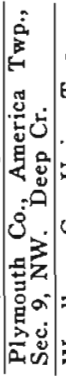 & 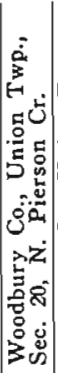 & 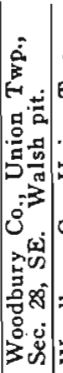 & 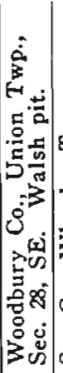 & 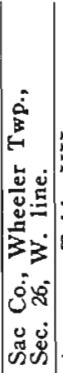 & 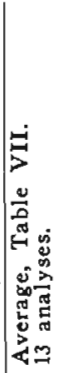 \\
\hline Granite-syenite & 27 & 44 & 29 & 27 & 17) & 21 & 24 & 33 & 28 & 22 & 23 & 19 & 14 & 25 \\
\hline e-gabbro & 4 & 2 & 6 & 6 & 6 & 1. & 4 & 1 & 1 & -- & 3 & & 4 & \\
\hline Basalt _- & 19 & 7 & 9 & 9 & 17 & 20 & 18 & 14 & 16 & $\begin{array}{r}10 \\
3\end{array}$ & 21 & 18 & 16 & 15 \\
\hline $\begin{array}{l}\text { Quartz } \\
\text { Miscel. igneous }\end{array}$ & $-\frac{-}{5}$ & -- & $\begin{array}{r}2 \\
--\end{array}$ & $-\frac{-}{1}$ & $\begin{array}{r}3 \\
--\end{array}$ & $\begin{array}{l}1 . \\
4\end{array}$ & $\begin{array}{l}4 \\
2\end{array}$ & & $\begin{array}{l}2 \\
3\end{array}$ & $\begin{array}{l}3 \\
1\end{array}$ & $\begin{array}{r}7 \\
5\end{array}$ & $-\overline{2}$ & $\begin{array}{l}4 \\
6\end{array}$ & \\
\hline igneous ....... & 55 & 53 & 46 & 43 & $\overline{4} \overline{3}$ & $4 \%$ & 52 & 51 & 50 & 36 & 59 & 39 & 44 & $4 \overline{7}$ \\
\hline zite.----------- & 7 & 11 & 7 & 11 & 6 & --1 & 5 & 3 & 4 & 9 & 10 & 5 & 9 & \\
\hline & & & 4 & 6 & 2 & 5 & 5 & & 6 & & 5 & & & \\
\hline and dolomite & 35 & 31 & 38 & 36 & 49 & 46 & 37 & 40 & 34 & 44 & 26 & 47 & 40 & 39 \\
\hline 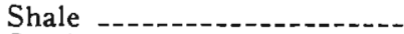 & --1 & -- & & -- & -- & -- & -- & --1 & , & -- & -- & --1 & -- & \\
\hline $\mathrm{S}$ & & - & & 3 & 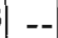 & 2 & 1 & 1 & 1 & -- & -- & 3 & 2 & \\
\hline & & -- & & $-\infty$ & -- & -- & - & -- & & -- & - & -- & & \\
\hline & 1 & & 5 & 1 & & & & - & 5 & 6 & -- & 3 & 4 & \\
\hline Total sedimentary & 45 & 47 & 54 & 57 & 57 & 53 & 48 & 49 & 50 & 64 & 41 & 61 & 56 & 53 \\
\hline
\end{tabular}

for the 23 analyses of tables VII and VIII combined, being all the Kansan-derived material, is shown in column $8 \mathrm{a}$ of Table IX. It is high in basalt and total igneous and low in limestone and total sedimentary. In general, those gravels which are farther down the valleys to the south and southwest show a somewhat larger percentage of the more resistant rock types, such as basalt, quartzite, chert and flint. This is illustrated by comparing the analyses of columns 5,6 and 7 of Table IX.

Table IX presents in summary form for ready comparison the averages of the several types of gravels in columns 1 to 8 . Columns $3 \mathrm{a}$, $6 \mathrm{a}$ and $8 \mathrm{a}$ give the averages for all the analyses of gravels interpreted as Wisconsin, Iowan and Kansan in age, respectively. Column 7a shows the average of the analyses in tables V, VI and VII combined, which include all the typical valley gravels of the Iowan and Kansan regions, a total of 88 analyses. Column 9 gives the average for all the analyses of all types recorded in the eight tables. 
TABLE VIII

Analyses of Pebbles from Gravel Masses Enclosed in, or Associated with Till that Is Apparently Kansan

\begin{tabular}{|c|c|c|c|c|c|c|c|c|c|c|c|}
\hline - & 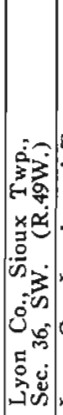 & 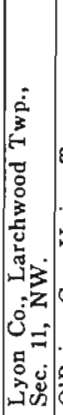 & 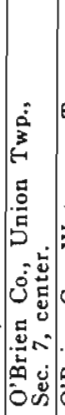 & 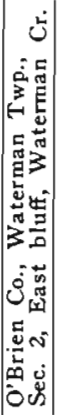 & 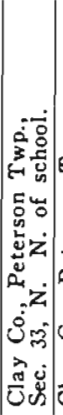 & 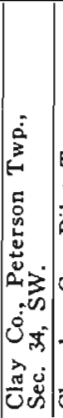 & 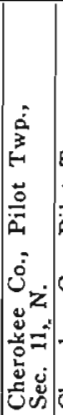 & 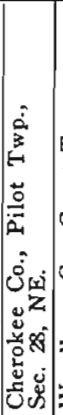 & 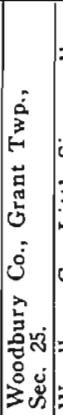 & 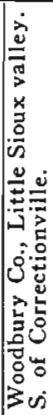 & 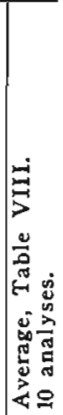 \\
\hline Granite-syenite -... & 12 & 22 & 30 & 25 & 201 & 23 & 30 & 31 & 19 & 26 & 24 \\
\hline Diorite-gabbro & 1 & 3 & 1 & -- & 3 & 1 & 4 & 1 & & & \\
\hline Basalt & 5 & 9 & 5 & 5 & 5 & 3 & 15 & 12 & 12 & 14 & \\
\hline 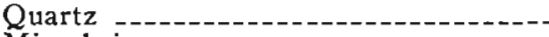 & -- & 1 & 2 & -- & 2 & -- & -- & -- & 2 & 2 & \\
\hline 1. igneous & 1 & & 18 & & & & 3 & 6 & & 6 & \\
\hline Total igneous & 19 & 35 & 56 & 30 & 30 & 27 & 52 & 50 & 33 & 48 & 38 \\
\hline Quartzite & 12 & 6 & 9 & - & -- & 3 & 1 & 4 & 3 & 2 & \\
\hline and flint & 4 & & 10 & -- & -- & --1 & 1 & 1 & 2 & 7 & \\
\hline stone and dolomite & 50 & 59 & 13 & 64 & 68 & 64 & 39 & 42 & 62 & 37 & 50 \\
\hline - & 3 & -- & -- & 6 & --1 & 6 & -- & --1 & -- & $=-$ & \\
\hline tone -1, & & -- & - & -- & -- & -- & -- & - & -- & - & \\
\hline balls & 12 & -- & -- & -- & - & -- & - & -- & -- & -- & \\
\hline edimentary _.......... & -- & -- & 12 & -- & 2 & -- & 7 & 3 & -- & 6 & \\
\hline Total sedimentary & 81 & $|65|$ & $|44|$ & 70 & $|70|$ & 73 & 48 & $|50|$ & 67 & 52 & 62 \\
\hline
\end{tabular}


TABLE IX

Summary of Averages of Analyses of Pebbles from the Several Types of Gravel

\begin{tabular}{|c|c|c|c|c|c|c|c|c|c|c|c|c|c|}
\hline - & 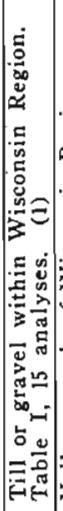 & 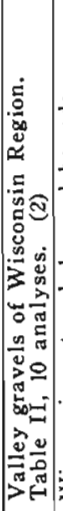 & 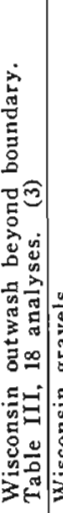 & 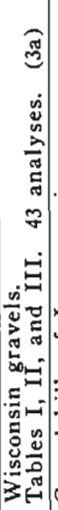 & 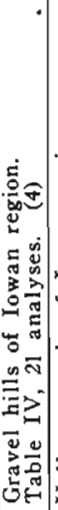 & 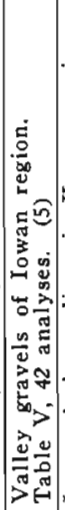 & 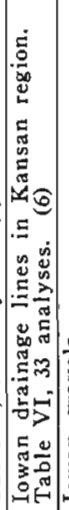 & 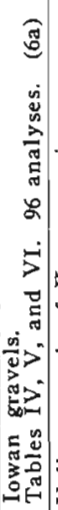 & 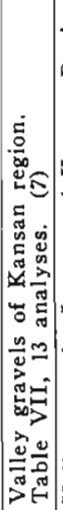 & 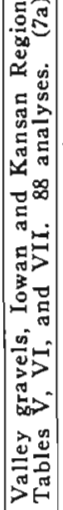 & 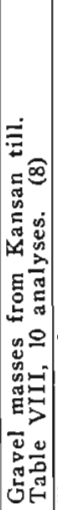 & 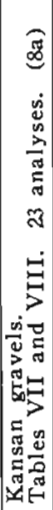 & | \\
\hline Granite-syenite & 20 & 26 & 29 & 25 & 18 & 18 & 28 & 21 & 25 & 23 & 24 & 24 & 23 \\
\hline Diorite-gabbro & 2 & 1 & 1 & 1 & 1 & 1 & 3 & 2 & 3 & 2 & 1 & 2 & 2 \\
\hline Basa & 9 & 7 & 7 & 8 & 4 & 7 & 12 & 8 & 15 & 10 & 9 & 12 & \\
\hline Quartz & 2 & 1 & 1 & 1 & 1 & 1 & 2 & 1 & 2 & 1 & 3 & 2 & \\
\hline Miscel. igneous & 2 & 1) & 2 & 2 & -_. & - & 1 & 1 & 2 & 1 & 1 & 3 & 2 \\
\hline Total igneous & 35 & 36 & 40 & 37 & 24 & 27 & 46 & 33 & 47 & 37 & 38 & 43 & 36 \\
\hline & 2 & 3 & 3 & 3 & 2 & 1 & 4 & 2 & 7 & 3 & 4 & 5 & 3 \\
\hline 0 & 1 & 1 & 1 & 1 & 1 & 1 & 3 & 1 & 4 & 2 & 3 & 3 & 1 \\
\hline Limestone and dolomite & $5 \overline{5}$ & 55 & 54 & 55 & 55 & 70 & 46 & 58 & 39 & $5 \overline{6}$ & 50 & 44 & 55 \\
\hline 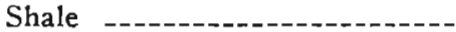 & 2 & 3 & 2 & 2 & 5 & 1 & - & 2 & -- & 1 & 1 . & 1 & 2 \\
\hline Istone --.- & -- & 1 & -- & 0 & & $\ldots$ & $-\infty$ & 0 & 1 & - & & 1 & 0 \\
\hline & & -- & - & 1 & 12 & -.. & - & 3 & -- & - & 1. & 1 & 2 \\
\hline $\mathrm{Mi}$ & & 1 & -- & 1 & 1 & -- & 1 & 1 & 2 & 1 & 3 & 2 & 1 \\
\hline Total sedimentary & 65 & $|64|$ & 60 & 63 & 76 & 73 & 54 & 67 & $5 \overline{3}$ & 63 & 62 & $5 \overline{7}$ & 64 \\
\hline
\end{tabular}




\section{CHAPTER VII}

\section{GEOLOGIC HISTORY AND CONCLUSIONS}

\section{Pleistocene History}

The geologic history of northwestern Iowa was traced in the report of $1917^{54}$ but the changes of interpretation used in the present report require that a part of the Pleistocene history be restated. The bases for the interpretations, and most of the interpretations have been stated in earlier parts of this report but are repeated here as a part of a connected tracing of the history.

Nebraskan Age.--The first ice sheet which invaded northwestern Iowa was the Nebraskan, the oldest ice sheet recognized in the Mississippi basin. It covered all of western Iowa, pushing southward into Missouri, and on its withdrawal left a mantle of 200 to 300 feet of till over much of northwestern Iowa. The Nebraskan ice advanced over a region underlain largely by soft Cretaceous shale and it left a compact, calcareous till with very little sand or gravel.

During the Aftonian interglacial age which followed there was developed over the level Nebraskan till plain in southern Iowa a horizon of gumbotil formed chiefly by long-continued chemical weathering. In northwestern Iowa the evidence is not so clear and decisive, but it is sufficient to show that a similar gumbotil zone developed as far north as Cherokee county and it probably extended over all of northwestern lowa. This gumbotil plain was then dissected, probably quite completely so, before the close of the Aftonian interglacial age. In the Cherokee region the erosion surface had a relief of 50 to 75 feet (page 76).

Kansan Age.-Following the Aftonian interglacial age the Kansan ice sheet developed. It advanced southward across Minnesota and Iowa, eastern North and South Dakota and eastern Nebraska and covered northern Missouri and northeastern Kansas. Its thickness in northwestern lowa was probably several thousand feet. As the Kansan ice sheet advanced over the eroded surface of Nebraskan till it plowed up great quantities of the Nebraskan, which it mixed with the

54 Iowa Geol. Survey, Vol. XXVI, pp. 430-443, 1917. 
material already carried, to make part of the Kansan till. Some small masses were inclosed without mixing in the Kansan till and at places the Kansan ice plowed up the Nebraskan surface but only partly mixed the tills, thus forming a transition zone. The thickness of Kansan till deposited was in most places between 100 and 200 feet.

For the history of the time following the withdrawal of the Kansan ice sheet we are again dependent upon the region farther south in Iowa. Over southern Iowa, as far north as Crawford and Carroll counties, the even drift plain left by the Kansan ice sheet remained for a long time undissected and on this plain there was developed a gumbotil zone. It is believed that a similar gumbotil zone was developed also over northwestern Iowa (pages 108 to 111 ). The development of these Nebraskan and Kansan gumbotils must have taken place very slowly and the Aftonian and Yarmouth intervals must have been very long.

Following the development of the Kansan gumbotil, the Kansan drift region was elevated and erosion began. In southern Iowa this erosion has lowered most of the country below the gumbotil plain but has left a few remnants. In northwestern Iowa there are no remnants of the gumbotil, and erosion is believed to have reduced all the country below the level of the original plain and to have removed every remnant of the gumbotil and of the leached zone of Kansan till below (pages 108 to 111 ).

The interval of time from the Kansan to the next ice invasion of northwestern Iowa (Iowan) includes the Yarmouth and Sangamon interglacial and the Illinoian glacial ages. The Kansan gumbotil was formed during the Yarmouth age. The dissection of the region continued through the Illinoian and Sangamon ages. During the later part of this interval silts and fine sands accumulated in some of the valleys of western Iowa, forming what are known as the Loveland deposits.

Iowan Age.-After the erosion of the Kansan region had progressed nearly to its present condition, northern Iowa was invaded by another ice sheet, the Iowan, which pushed into our region from the northeast to a line extending from eastern Lyon county through Cherokee to southwestern Sac county (Plate I). The Iowan ice sheet appears to have deposited only a thin veneer of drift in most places. It did not, therefore, make a distinctive constructional topography, but merely mantled the then existing topography cut in the Kansan drift, 
producing a region in which the larger relief features are erosional but with the slopes modified by minor constructional features (page 41).

During the general stage of ice advance there were temporary withdrawals, and during the general stage of retreat there were temporary advances. As a result of these oscillations of the ice fronit, gravel that was laid down just beyond the ice front was later overridden.and buried under till. In some places the oscillations were repeated several times and resulted in several alternations of the till and gravel as described for the Mill creek bluffs north of Cherokee (pages 84 to 88). Deposits in moulins in the ice or at the edge of the ice formed the kamelike gravel hills (pages 90 to 102).

During the advance, and particularly during the withdrawal of the Iowan ice sheet, great floods of water loaded with debris flowed out from its front, down the valleys to the south and southwest and deposited gravel in most of the valleys of the region, forming the deposits which have been described in Chapter $\mathrm{V}$ as the valley gravels.

After the Iowan ice age, and apparently soon after the deposition of the valley gravels, northwestern Iowa was covered with a mantle of loess, the material for which was derived chiefly from the valley flats on the west line of the state. Near Missouri river 20 to 30 feet of loess were deposited, but this decreased eastward across the Kansan region to two to four feet over most of the Iowan region. Since the loess was formed it has been leached to a depth of two to four fect, but on the whole the Iowan drift region has suffered little erosion and the till is notably fresh.

Wisconsin Age.-At a still later date a lobe of the Wisconsin ice sheet advanced southward across north-central Iowa, with its west edge across the eastern part of our region, as shown on Plate I. The Wisconsin ice sheet left a drift surface with definite glacial features, including prominent morainic topography. Very little modification of this topography has been produced by the erosion of post-Wisconsin time except along some of the larger streams, which have cut prominent trenchlike valleys.

\section{Summary of Conclusions}

Conclusions and interpretations have been given in connection with each subject discussed but brief statements of the more important conclusions are brought together here in the form of a summary. 
Iowan Region.-Two drift regions exist in northwestern Iowa west of the Wisconsin drift boundary in the area previously interpreted as Kansan (Plate II). The eastern part of this area, lying between the definite Wisconsin on the east and the more definite Kansan on the west, is here differentiated as a distinct drift region formed by an ice sheet that pushed into northwestern Iowa from the northeast and advanced about halfway across our region to a boundary shown on Plate $I$ and traced on pages 59 to 84 . The peculiar topography of this region, consisting of a well developed valley system with faintly constructional slopes, is explained by the interpretation that the ice sheet which formed this region deposited only a thin mantle of drift which modifies slightly a pre-existing erosional topography (page 41 ).

This drift region is assigned to the Iowan age and correlated with the Iowan of eastern Iowa on the bases of similar topography, similar relations to the Kansan below and to the overlying mantle of loess, and similar geographical positions with respect to the later Wisconsin drift region (page 39 ).

Kansan Region.-That part of northwestern Iowa west of the Iowan boundary is interpreted as Kansan. The absence of leached till in this Kansan region as contrasted with the Kansan region farther soluth in western Iowa is explained by the interpretation that northwestern Iowa suffered more extensive erosion which completely removed the leached zone and gumbotil zone, if these had been developed (pages 108 to 111). This erosion took place before the Iowan age. The possibility of explaining the absence of the leached zone by assuming that it was never developed, owing to some climatic differences, is recognized.

The Loess.-Both the Kansan region and the Iowan region are covered with loess (pages 116 to 136). In the southwest part of our area, near Missouri river, this is typical loess and is thick. To the northeast it becomes thinner and over much of the Iowan region it is only two to four feet thick. Lithologically this thin loess may not be typical loess, but it is certainly the time equivalent of the loess. The age of this loess is interpreted as Peorian, as in eastern Iowa (pages 134 to 136$)$.

Interbedded Gravel and Till.-An interbedding of gravel and till characterizes several exposures within the Iowan region (pages 84 to 89). These deposits were formed by oscillations of the ice front 
during the general stages of advance and retreat. By these oscillations, gravel deposited just beyond the ice edge may have been laid down on till only recently deposited and may soon have been buried by till. The freshness of the gravel and till of these layers shows that neither was exposed long at the surface before the next higher member was deposited.

The Gravel Hills. - The kamelike gravel hills of the Iowan region (pages 90 to 102) are interpreted as gravel masses deposited in moulins or other openings in the Iowan ice sheet. On the melting of the ice these masses were left on or in the upper part of the drift sheet.

The Valley Gravels. - The valley gravels of the Iowan region and of the valleys of the Kansan region that carried Iowan drainage are interpreted as outwash from the Iowan ice chiefly during the withdrawal of the ice sheet (pages 166 to 170). The valley gravels in those valleys of the Kansan region that did not receive Iowan drainage are believed to have been released from the Kansan till during an especially active period of erosion, owing to the lack of vegetation during the Iowan ice age, and to have accumulated farther down the valleys (pages 168 to 170 ). 



\section{INDEX}

A

Adrian, Minnesota, Iowan boundary near, 60; loess near, 134

Aftonian ? gravels, age, 115

Aftonian interglacial age, history, 183

Alden and Leighton, work on lowan drift, 36

Alta, loess and till near, 127

"Altamont Moraine" in northwestern Iowa, 28

Alton, gravel near, 146

Apfel, E. T., cited, 109; work in Iowa, 37, 51

Arion, gravel near, 166

Arthur, loess near, 124

\section{B}

Bain, H. F., cited, 146; work of, 24-27

Benches, see valley. gravels

Beyer, S. W., cited, 145

Big Sioux river, gravels in, 138; tributaries, gravel in, 144

Boyer, fossils from, 166; loess near, 124

Boyer river, gravel in, 163; Iowan boundary near, 82

Buena Vista county, analyses of pebbles from, 172, 174, 177; drift in, 31; gravel masses in, 113; Iowan drift in, 39, 43, 58, 126; Kansan drift in, 127; loess in, 126; valley gravels in, 151,159

\section{C}

Calvin, Samuel, cited, 30; opinion of, on Iowan drift, 36

Carman, J. Ernest, report by, 1917, 21; summary and conclusions, 1917, 35; work of, in northwestern Iowa, 32-37

Carroll county, analyses of pebbles from, 172; drift in, 26; gumbotil in, 109, 110; Kansan drift in, 106

Chamberlin in Geikie's Great Ice Age, 24
Cherokee, glacial deposits near, 51; gravel masses near, 114; Iowan boundary near, 70; Iowan gravels near, 71; loess near, 127

Cherokee county, analyses of pebbles from, 175-177, 179, 181; drift in, 31; fossils from, 165; gravel and till in, 84; gravel hills in, 96; gravel masses in, 114; Iowan boundary in, 68; Iowan drift in, 39, 43, 52; Kansan drift in, 103, 128; loess in, 117, 126, 127; Loveland beds in, 50, 73; Nebraskan in, 74; Pilot Rock in, 108; valley gravels in, 153, 156, 161

Cherokee Sand and Gravel Company, pits of, 56; fossils from, 165

Clay-balls in gravels, $85 \mathrm{ff}, 172 \mathrm{ff}$; in gravel hills, 100

Clay county, analyses of pebbles from, $172,174,177,181$; drift in, 30 ; gravel in, 113,151 ; Iowan drift in, $39,42,58$; loess in, 120, 131

Concretions, calcareous, in Kansan till, 106

Correctionville, fossils from, 146; gravel near, 153, 161

Coteau des Prairies, Iowan boundary on, 63

Crawford county, fossils from, 166; gravel in, 164, 166; gravel masses in, 114; gumbotil in, 109; loess in, 124

Cretaceous system of northwestern Iowa, 107

\section{D}

Deep creek, gravel in, 147

Devonian rocks, source of pebbles, 107

Dickens outlet, gravel in, 151

Dickinson county, analyses of pebbles from, 172-174; drift in, 30; Iowan drift in, 39, 43; loess in, 120, 131

Doon, gravel near, 140, 144

Doupe farm, exposures on, 53

Drift, source of material for, 107 


\section{$\mathbf{E}$}

Early, gravel near, 163; loess near, 125

Emmet county, analyses of pebbles from, 172, 173

$\mathbf{F}$

Ferretto, lacking in northwestern Iowa, 108

Fleming, Paul, pit, fossils from, 165

Floyd river, gravel in, 145; Iowan' boundary near, 64

Fossils from valley gravels, 164; in gravels, 148

\section{G}

Galva, gravel near, 163; Iowan boundary near, 78; loess near, 119, 125

Geikie's Great Ice Age, 24

Geologic history and conclusions, 183

George, gravel neár, 141; Iowan drift near, 64

Gillett. Grove, gravel near, 152

Granite, gravels near, 139

Gravel and sand masses included in till, 111,115

Gravel and till, interbedded, 84 ; origin, 89,186

Gravel boulders and gravel hills in northwestern Iowa, 35, 111-115

Gravel hills, distribution and description, 91 ; location, 100 ; material, 100 ; nature, 90 ; origin, 99, 187 ; in Cherokee county, 78, 96; in Ida county, 98; in Iowan drift area, 90; in Lyon county, 91; in Nobles county, Minnesota, 92; in O'Brien county, 93; in Osceola county, 92; in Sac county, 98

Gravel masses, analyses of pebbles from, 181, 182; description, 113; origin, 115; size and character, 112

Gravels, analyses, 171-182; composition, $112,138,167$; in Mill creek valley, 68 ; rock types of, 172 ; see also Gravel Hills, Va.ley Gravels

Gravels, valley, age, 144, 149, 150, 152, $154,160,162,163,166$; analyses of pebbles from, 180, 182; fossils from, 164 ; nature, 138 ; origin, $137,166,187$; distribution and description, 138-164; in Big Sioux river basin, 138; in Rock river basin, 140; in Floyd river basin, 144; in Little Sioux river basin, 149; in Maple river basin, 162; in Boyer river basin, 163

Grimes, C. H., pit of, 147

Gumbotil, absent from northwestern Iowa, 109; altitude, 110; Kansan, formation, 184; in southern Iowa, 109; Nebraskan, formation, 183 ; in Cherokee county, 52; origin and character, 109

\section{H}

Harrison county, gravel in, 115

Hay, O. P., cited, 165

Holstein, loess near, 126

\section{I}

Ida county, analyses of pebbles from, 175, 179; drift in, 32; gravel hills in, 98; Iowan boundary in, 78; Iowan drift in, 39, 43; Kansan drift in, 103, 125 ; loess in, 116, 124; Loveland in, 126

Ida Grove, gravel near, 163

Igneous pebbles of till, origin, 107

Illinoian glacial age, history, 184

Intermediate drift region, correlation with Iowan, 39, 135

Iowa, northwestern, glacial history, 109 ; report on, 1917,21

Iowan age, history, 184

Iowan boundary, course of, 59; in Cherokee county; 68; in Ida county, 78 ; in Lyon county, 60,63 ; in Nobles county, Minnesota, 60; in O'Brien county, 66; in Sac county, 79,81 ; in Sioux county, 64

Iowan (?) drift in Plymouth county, 26 Iowan drift, exposures, 52; general character, 48; interbedded with gravel, 84 ; relation to Loveland deposits, 49; in Buena Vista county, 58; in Cherokee county, 50, 52; in Clay county, 58; in Dickinson county, 39; in Ida county, 34; in Lyon county, 39 ; in northwestern Iowa, 21, 25; in O'Brien county, 51, 58; in Osceola 
county, 61; in Sac county, 39, 43, 59; in Sioux county, 39; near Wall Lake outlet, 59

Iowan drift region of northwestern Iowa, aggraded areas, 46; analyses of pebbles from 175, 176, 182; area, 39; boundary, 59-84; character, 186; correlation, 39; drainage, 154; drainage pattern, 41 ; erosional topography along valleys, 44; gravel benches, 46 ; gravel hills, 46, 96, 99; gravels, 168 ; level area, 42; moderately rolling areas, 43 ; relation to loess, 116,118 ; slightly rolling areas, 42 ; topography, $40-48,60-84$

Iowan gravels in Cherokee county, 71, 78, 84; in Little Sioux valley, 73; see also Gravels, Valley

\section{K}

Kames in gravel hills, $60,78,101$

Kansan age, history, 183

Kansan drift, character, 105 ; in northwestern Iowa, $21,27,35,50-55$; oxidized phase, 105; pebbles in, 106; unoxidized phase, 106

Kansan drift region, analyses of pebbles from, 178-182; area, 103; character, 186; gravels, 168; history, 108; mature erosion, 104; topography, 65, 103

Kansan gumbotil, formation, 184; in southern Iowa, 109

Kay, George F., cited, 109-111, 115; use of term Loveland, 49; work of, in northwestern Iowa, 34, 37; and Apfel, cited, 51

Kiron, gumbotil near, 109

Klondike, gravels near, 139

\section{L}

Lees, James H.; cited, 109, 164

Leighton, M. M., see Alden and Leighton

Le Mars, fossils from, 164; gravel near, 146

Leverett, Frank, beliefs on age of Iowan, 34, 36, 37, 40; Iowan boundary mapped in Minnesota by, 60 ; work of, in Iowa, 28, 33, 37, 51; and
Sardeson, cited, 40, 60; work of, in Minnesota, 36

Limestone pebbles of till, origin, 107

Little Rock, gravel hills near, 60; loess near, 133

Little Rock river, gravel in, 141, 144; Iowan boundary near, 60

Little Sioux valley, exposures in, 51; gravel in, 149; Iowan boundary near, 70; Iowan gravels in, 73 ; profile across tributary, 45; topography along, 45

Loess, characteristics and distribution, 116,120 , 186; formation, 185, 186; medium thickness, region of, 119 ; origin and age, 134; pebbles in and on surface, 121; Peorian age, 135, 186; nature and thickness, 123, 134; thick, region of, 116; thin, region of, 119; topography, 116; in Buena Vista county, 126; in Cherokee county, 127; in Clay county, 131; in Crawford county, 124; in Dickinson county, 132; in Ida county, 124; in Lyon county, 132; in Nobles county, Minn., 133 ; in O'Brien county, 130; in Osceola county, 132; in Plymouth county, 130; in Sac county, 124; in Sioux county, 131

Loess and till, relations, 122

Loess overlying gravel, 167

Loveland deposits, formation, 184; in Cherokee county, 50, 73; in Ida county, 126; in northwestern Iowa, 49; in O'Brien county, 51 ; in Plymouth county, 130

Lyon county, analyses of pebbles from, 175, 178-181; drift in, 27; gravel hills in, 91 ; gravels in, 139; Iowan boundary in, 60, 63; Iowan drift in, 133; loess in, 116,133

\section{$\mathbf{M}$}

Macbride, T. H., cited, 48, 96, 98, 168; work of, $30-32$

MacClintock, work of, in Iowa, 37, 51

Maple River valley, gravel in, 162; Iowan boundary near, 70,78

Milford, gravel near, 150 
Mill creek valley, age of, 69; exposures in, 59; gravels in, 68, 153, 156; Iowan boundary near, 66; profiles along, 157; till and gravel in, 84

Minnesota, analyses of pebbles from, 175; Iowan drift in, 39; Nobles county, gravel hills in, 92; Iowan boundary in, 60; loess in, 133

Missouri river loess, 135

Monona county, gravel masses in, 115; loess in, 117

Moulins or wells in Iowan ice, 99

Murry creek, gravel in, 155; profile along, 157

\section{N}

Nebraskan age, history, 183

Nebraskan drift in northwestern Iowa, 52, 73; in Cherokee county, 52, 74; source of drift material, 108

Nebraskan gumbotil, formation, 183; near Cherokee, 52

Nobles county, Minn., analyses of pebbles from, 175; gravel hills in, 92; Iowan boundary in, 60; loess in, 133

Northwestern Iowa, geological work in, 24

\section{O}

O'Brien county, analyses of pebbles from, 175-177, 181; drift in, 30; gravel hills in, 93; gravel masses in, 113; Iowan boundary in, 66; Iowan drift in, 42, 58, 131; Kansan drift in, 103; loess in, 119, 120, 130; Loveland beds in, 51 ; valley gravels in, 145, 152

Ocheyedan-Little Sioux system, diversion, 46

Odebolt, Iowan boundary near, 79; loess near, 118,124

Okoboji outlet, gravel in, 149

Ordovician fossils in limestone, 107

Ordovician rocks, source of pebbles, 107

Osceola county, analyses of pebbles from, 172, 175, 176; drift in, 30; gravel hills in, 92; Iowan drift in, 42, 61 ; loess in, 120,132 ; valley gravel in, 141

Oto, gravel near, 154

Oyens, gravel near, 147

\section{$\mathbf{P}$}

Palo Alto county, analyses of pebbles from, 173

Paullina, gravel near, 157 ; Iowan boundary near, 69

Pearce, J. N., cited, 109

Pebbles, analyses, 171 ; in and on surface of loess, 121; in drift, origin, 107

Peorian age of loess, 135, 186

Peorian loess, see loess

Peterson, gravel masses near, 113

Pierson, gravel near, 162

Pilot Rock, Cherokee county, 108

Pleistocene history of northwestern Iowa, 183

Plymouth county, analyses of pebbles from, 180; drift in, 25; gravel in, 145; Kansan in, 103 ; loess in, 116, 122, 126, 130; Loveland in, 130

Pre-Cambrian rocks, source of pebbles, 107

Primghar, Iowan gravels near, 69, 157

Profile across tributary of Little Sioux, 45

Profiles along Little Sioux river, 150, 152; Mill creek valley, 157; Murry creek valley, 156; Waterman creek valley, 155

$\mathbf{R}$

Rock Rapids, fossils from, 165; gravel near, 140

Rock River valley, gravels in, 140, 144

Rock types of gravels, 172

Rock Valley, gravel near, 140

\section{S}

Sac county, analyses of pebbles from, $173,175,180$; drift in, 32 ; gravel hills in, 98; gravel in, 163; Iowan boundary in, 79,81 ; Iowan drift in, 43; Iowan drift topography in, 83; Kansan in, 103; loess in, 116, 124

Salisbury, R. D., work of, in Iowa, 24

Sand and gravel bowlders, description, 111 ; origin, 115

Sangamon interglacial age, history, 184; Loveland deposits of, 49 
Sardeson, Frederick W., cited, 36; and Leverett, cited, 60

Schaller, loess near, 125

Sheldon, gravel near, 146; Iowan boundary near, 64; loess near, 131; Loveland beds near, 51

Shimek, B., cited, 134, 139; naming of Loveland, 49

Sibley, gravel near, 142, 144; loess near, 132 ; till near, 133,142

Silurian rocks, source of pebbles, 107

Sioux county, analyses of pebbles from, 178, 179; drift in, 27; gravel in, 140, 145; Kansan in, 103; loess in, 116, 130

Sioux Falls, gravel masses near, 114; Sioux quartzite near, 107

Sioux quartzite in drift, 107

Sioux Rapids, gravel masses near, 113 gravel near, 152

South Dakota, gravel masses in, 114; Iowan drift in, 39; Sioux quartzite in, 107

Spencer, gravel near, 149, 151; Iowan topography near, 43

Spencer flat, sand hills north of, 47

Storm lake, gravel masses near, 114; loess near, 126

Sutherland, gravel near, 156

\section{$\mathrm{T}$}

Terraces, see valley gravels

Till, gravel and sand masses included in, 111

Till and gravel interbedded, 84

Till and loess, relations, 122

Todd, J. E., work of, in Iowa, 28
Topography, pre-Iowan, 41 ; of Iowan drift, 40-48, 60-84; of Kansan drift region, 103

Turner, F. R., gravel pits on farm of, 57

\section{$\mathbf{U}$}

Union county, gravel in, 115

Uplift in northwestern Iowa, 111

\section{V}

Valley gravels in northwestern Iowa, 35; see Gravels

\section{W}

Wall Lake, loess near, 117, 118, 124

Wall Lake outlet, gravel in, 164; Iowan boundary near, 82; Iowan drift near, 59

Walsh Brothers pit, 161; fossils from, 165

Waterman creek, gravel in, 155; profiles along, 155

Wilder, F. A., cited, 168; work in Lyon and Sioux counties, 27

Wisconsin age, history, 185

Wisconsin drift in northwestern Iowa, 28

Wisconsin drift region, analyses of pebbles from, 172-174, 182

Wisconsin boundary, drainage of, 151

Woodbury county, analyses of pebbles from, 179-181; gravel in, 153, 161; loess in, 116

\section{Y}

Yarmouth interglacial age, history, 184 
$\therefore$

\section{.}


(1)

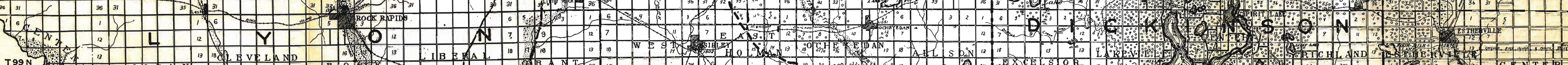

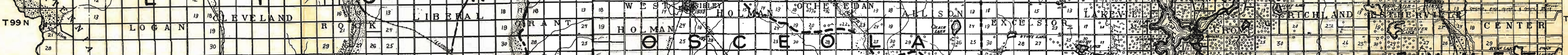

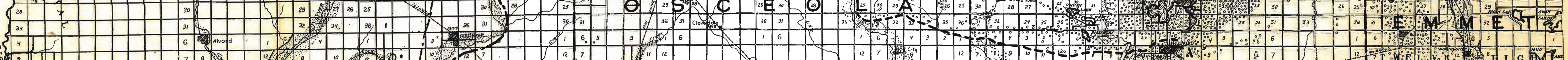
(1. C.

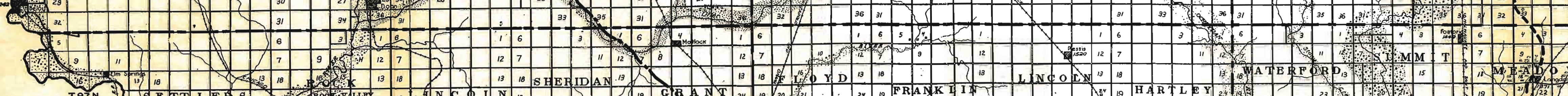

(n) (1).

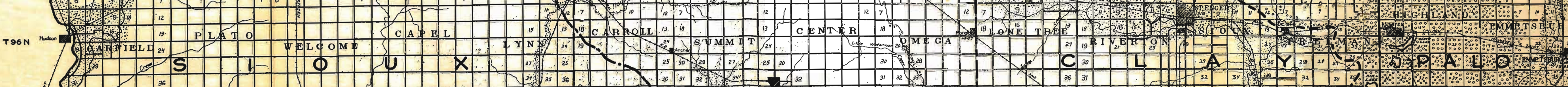

4

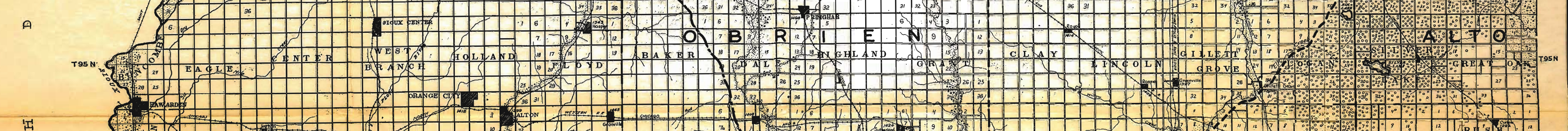

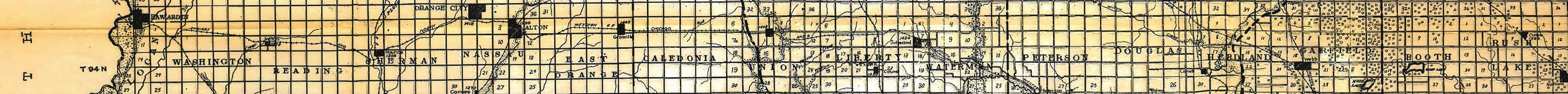
(

T.

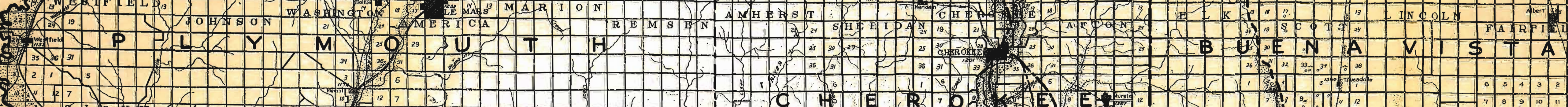

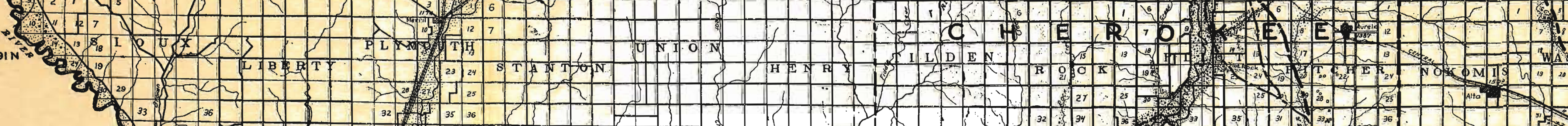

(1)

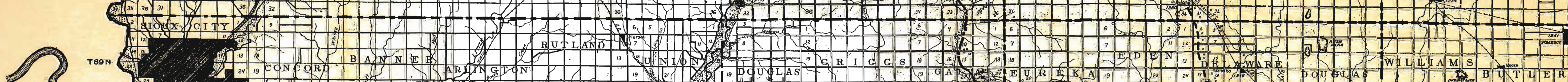

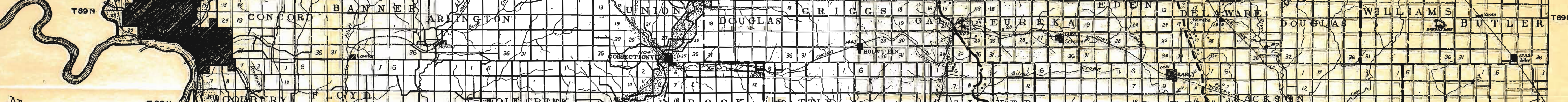
小

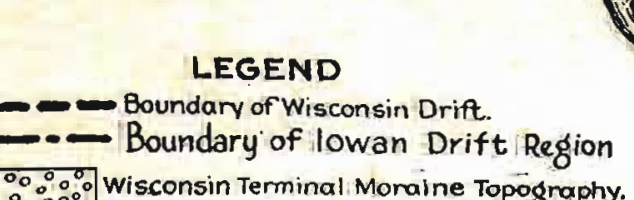

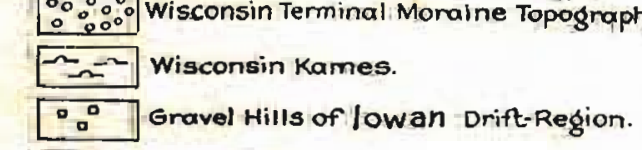

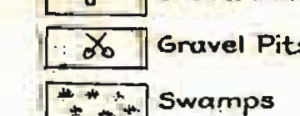

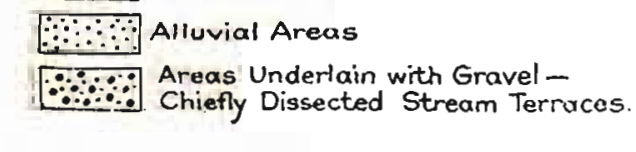

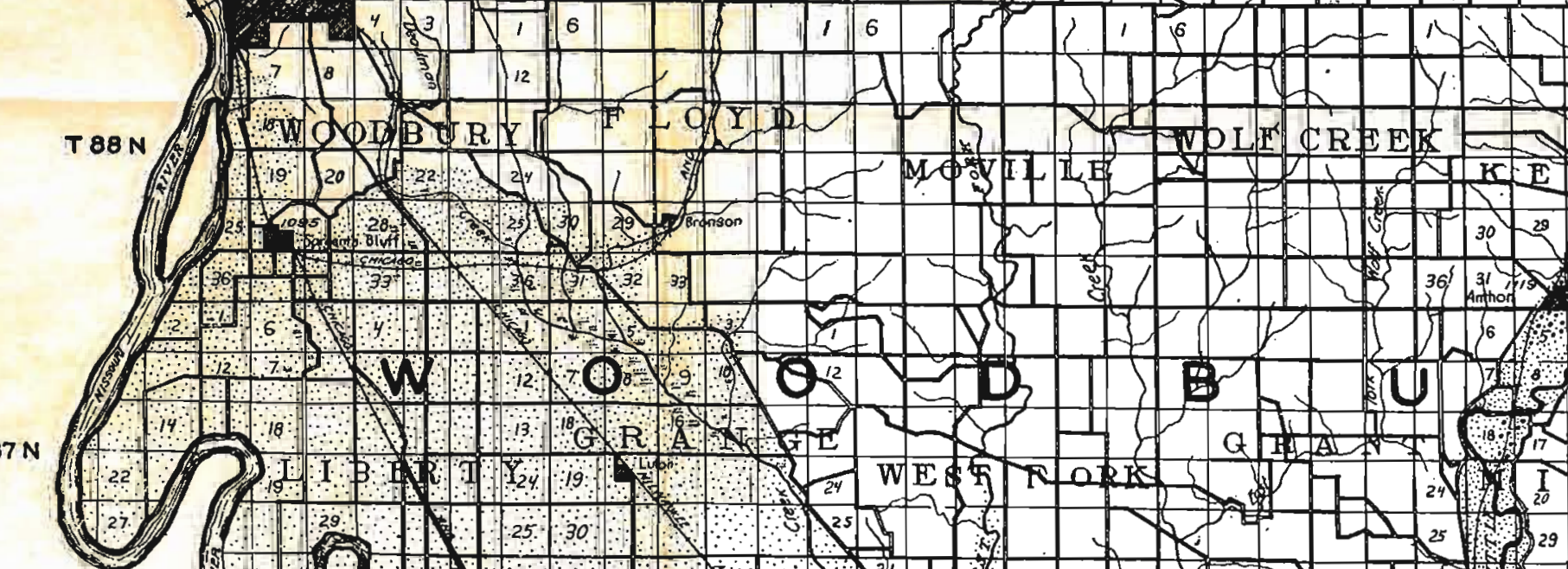

2.

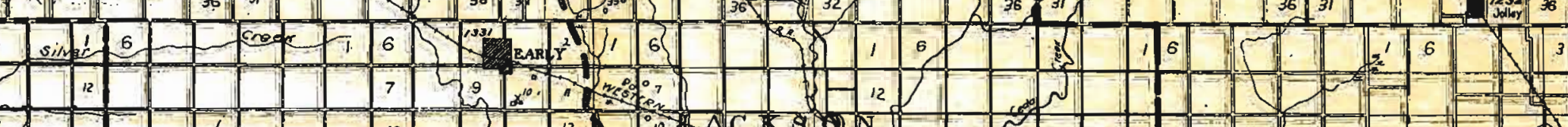
araction - enarent (1) tin

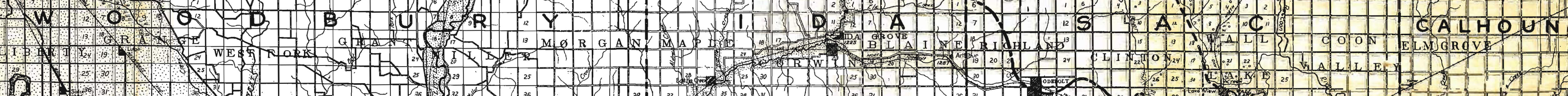
(4.1.1)

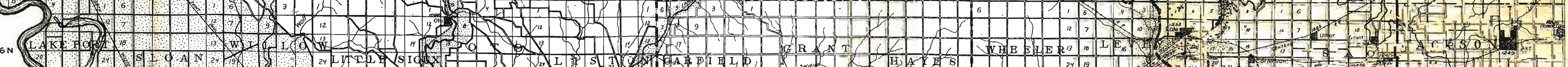
1.1.2. 2. P

${ }^{6}{ }^{3}$ 